A GUIDE TO THE LATE
QUATERNARY HISTORY OF
NORTHERN AND WESTERN
KENAI PENINSULA, ALASKA

by R.D. Reger, A.G. Sturmann, E.E. Berg, and P.A.C. Burns

Guidebook 8

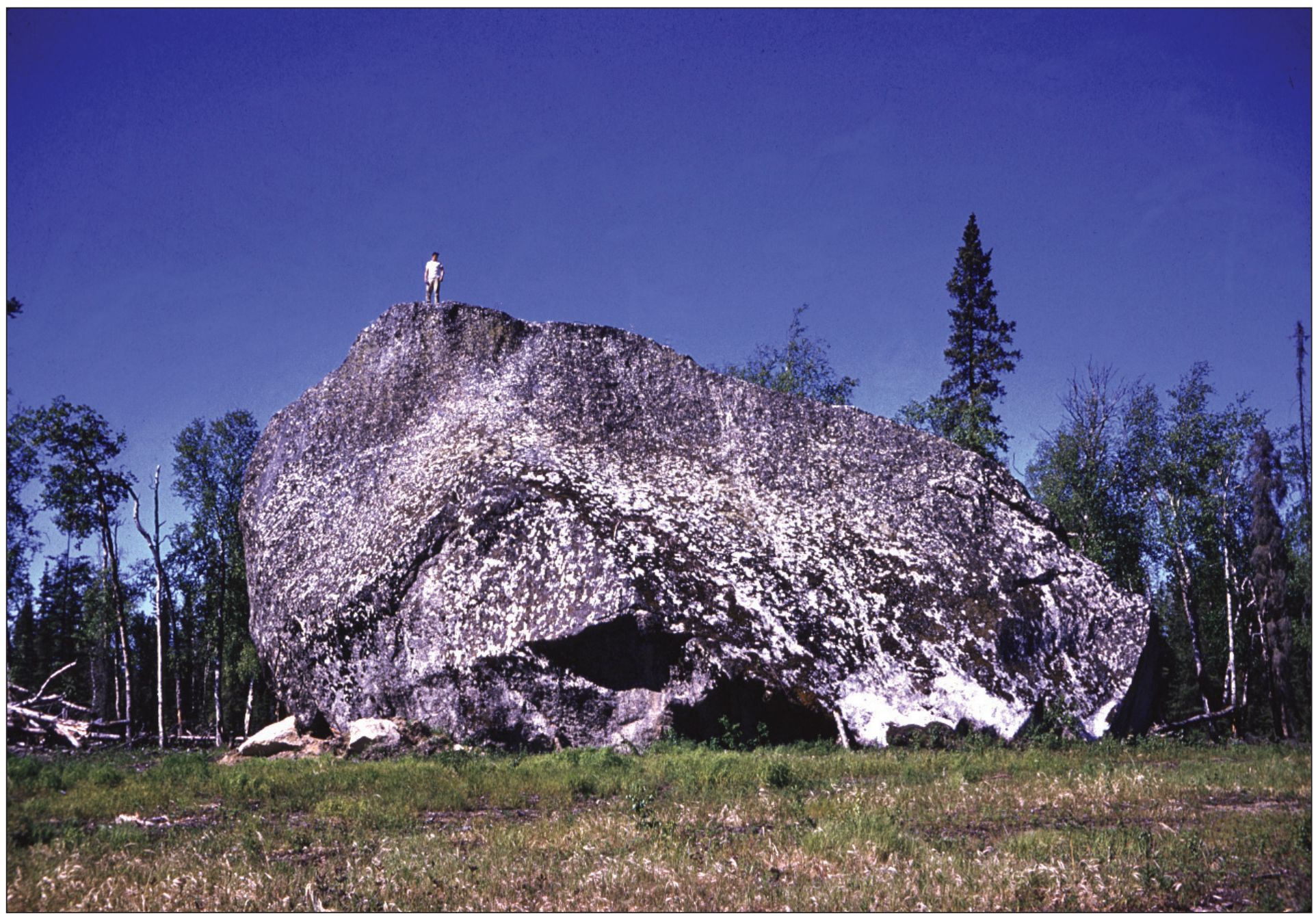

Published by

STATE OF ALASKA

DEPARTMENT OF NATURAL RESOURCES DIVISION OF GEOLOGICAL \& GEOPHYSICAL SURVEYS 


\title{
A GUIDE TO THE LATE QUATERNARY HISTORY OF NORTHERN AND WESTERN KENAI PENINSULA, ALASKA
}

by R.D. Reger, A.G. Sturmann, E.E. Berg, and P.A.C. Burns

\section{Division of Geological \& Geophysical Surveys}

\author{
Guidebook 8
}

Cover photo: Granitic erratic, measuring $15 \mathrm{~m}$ (50 ft) high by $30 \mathrm{~m}$ (100 ft) long, was probably carried southward at least $160 \mathrm{~km}$ (100 mi) from the Talkeetna Mountains by ice of the Moosehorn stade of the last major glaciation and deposited in the southwest quarter of Kenai C-3 SW Quadrangle. This huge block is one of a series of granitic monoliths that form a north-trending block train across northeastern Kenai Peninsula lowland. 


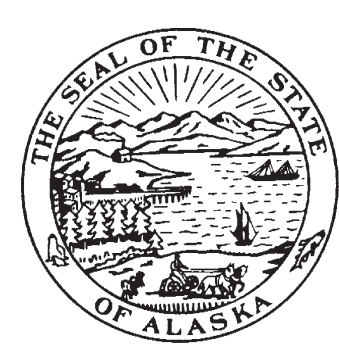

STATE OF ALASKA

Sarah Palin, Governor

DEPARTMENT OF NATURAL RESOURCES

Tom Irwin, Commissioner

\title{
DIVISION OF GEOLOGICAL \& GEOPHYSICAL SURVEYS \\ Robert F. Swenson, State Geologist and Acting Director
}

\begin{abstract}
Division of Geological \& Geophysical Surveys publications can be inspected at the
\end{abstract} following locations. Address mail orders to the Fairbanks office.

\author{
Alaska Division of Geological \\ \& Geophysical Surveys \\ 3354 College Road \\ Fairbanks, Alaska 99709-3707 \\ Elmer E. Rasmuson Library \\ University of Alaska Fairbanks \\ Fairbanks, Alaska 99775-1005
}

University of Alaska Anchorage Library 3211 Providence Drive

Anchorage, Alaska 99508

\author{
Alaska Resource Library \\ and Information Services (ARLIS) \\ 3150 C Street, Suite 100 \\ Anchorage, Alaska 99503
}

\begin{abstract}
Alaska State Library
State Office Building, 8th Floor

333 Willoughby Avenue

Juneau, Alaska 99811-0571
\end{abstract}

This publication released by the Division of Geological \& Geophysical Surveys was produced and printed in Anchorage, Alaska at a cost of \$25.00 per copy. Publication is required by Alaska Statute 41, "to determine the potential of Alaskan land for production of metals, minerals, fuels, and geothermal resources; the location and supplies of groundwater and construction materials; the potential geologic hazards to buildings, roads, bridges, and other installations and structures; and shall conduct such other surveys and investigations as will advance knowledge of the geology of Alaska.” 


\section{CONTENTS}

Introduction

Acknowledgments.

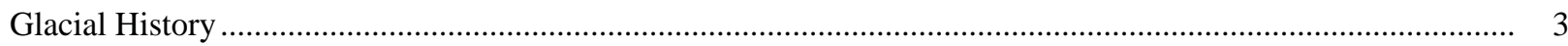

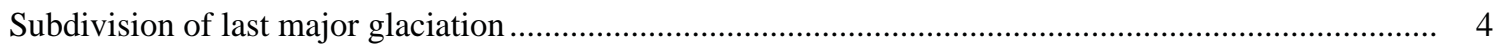

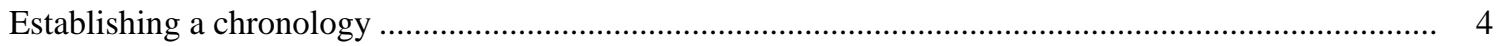

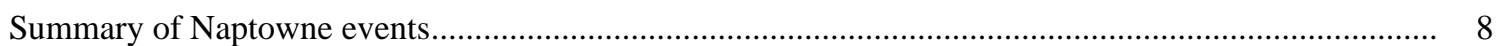

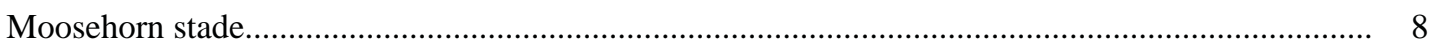

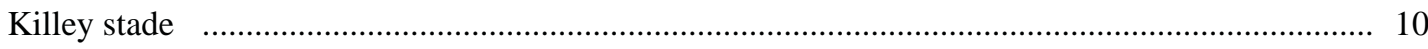

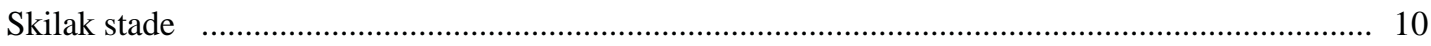

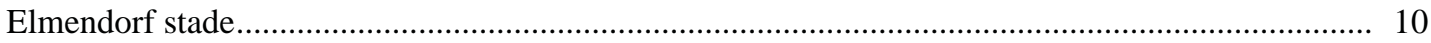

Holocene glaciation of northern Kenai Mountains ........................................................................ 10

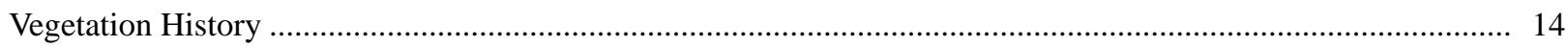

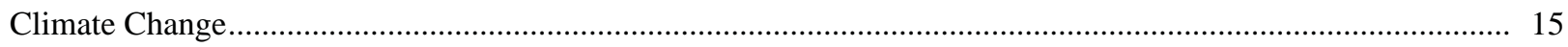

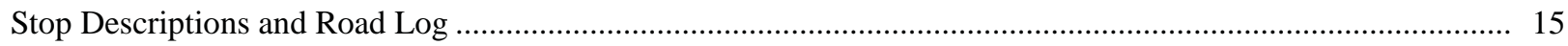

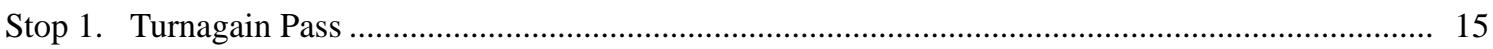

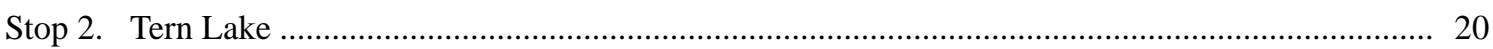

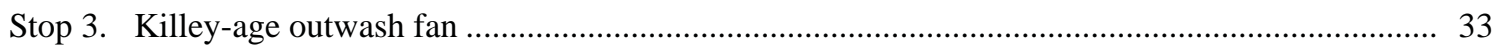

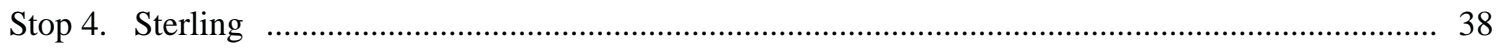

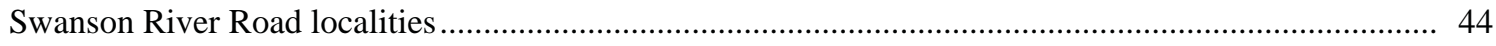

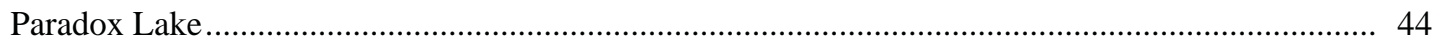

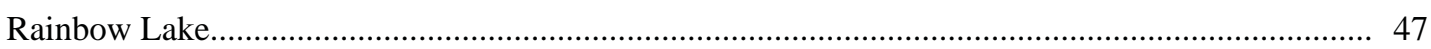

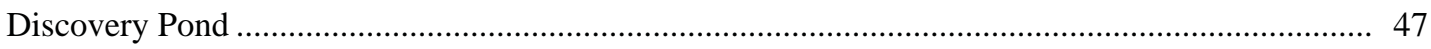

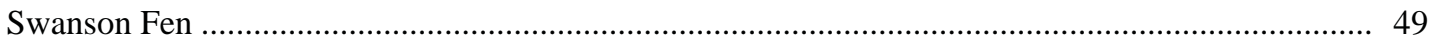

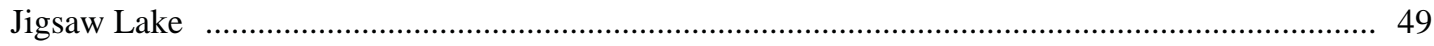

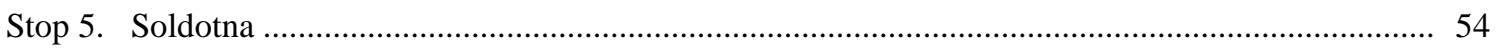

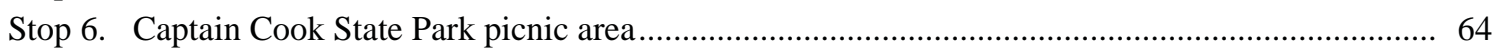

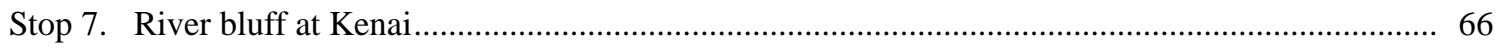

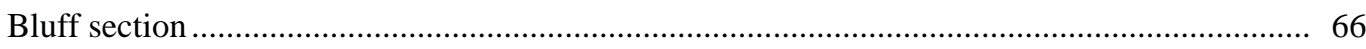

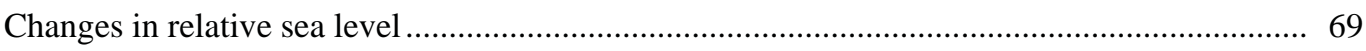

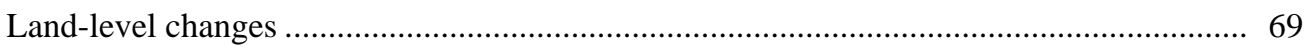

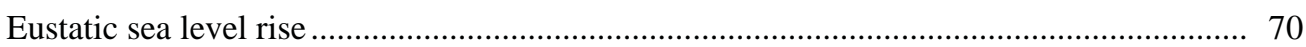

Basal peat dates as evidence of climatic change ............................................................ 71

Other evidence of climatic change ................................................................................... 74

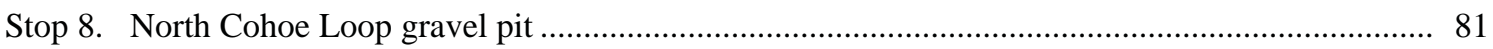

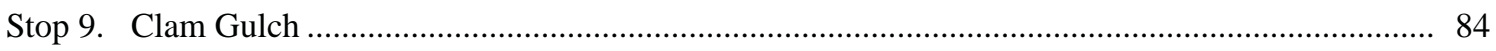

Stop 10. Paleochannel of ancestral Happy Valley Creek............................................................... 88

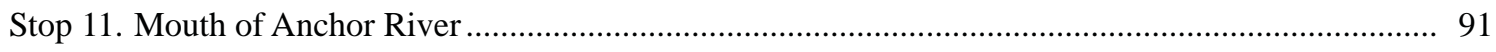

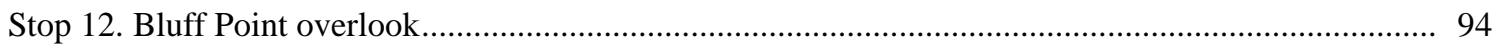

Stop 13. Karen A. Hornaday Hillside Park.................................................................................... 96

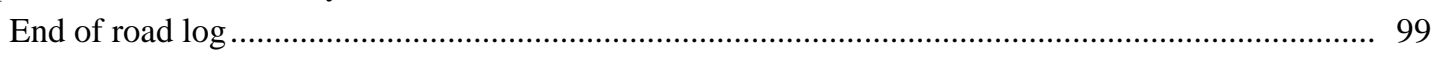

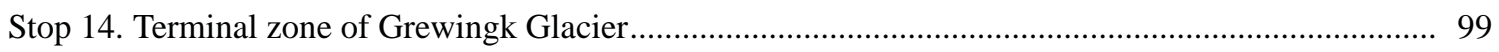

Holocene glaciation of southern Kenai Mountains ............................................................ 99

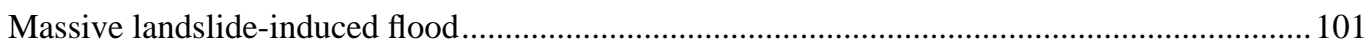

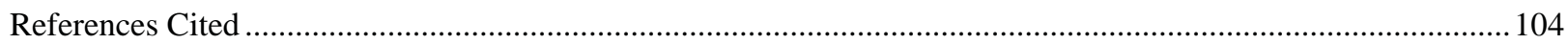

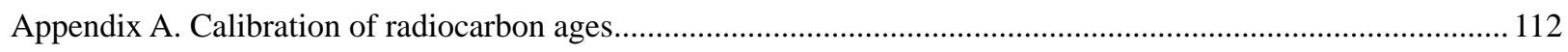




\section{TABLES}

Table 1. Summary field description of soil profile near Stop 1 on crest of latest-Naptowne moraine

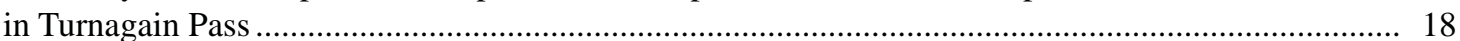

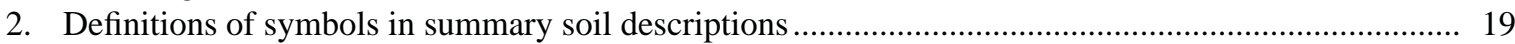

3. Changes in Soldotna reach of lower Kenai River during and after Naptowne glaciation ....................... 55

4. Names and location data of peat coring sites in Cook Inlet region (fig. 63).......................................... 73

5. Correlation and implications of stratigraphy along west coast of Kenai Peninsula lowland north of Clam Gulch

\section{FIGURES}

Figure 1. Map of Kenai Peninsula showing locations of geographic features and field-trip stops ....................... 2

2. Paleogeography of southcentral Alaska at climax of last major glaciation ........................................... 3

3. Effects of climatic gradient across Kenai Mountains and Cook Inlet trough at climax of last major glaciation

4. Model of Naptowne glaciation in Cook Inlet region, showing principal ice-flow directions

5. Physiographic map of type area of Naptowne glaciation

6. Summary of late Quaternary events in Cook Inlet region ......

7. Comparison of time-distance curves of principal ice streams in Kenai Peninsula lowland during Naptowne glaciation

Paleogeography of eastern and northern Cook Inlet region during Moosehorn stade of Naptowne glaciation

Paleogeography of eastern and northern Cook Inlet region during Killey stade of Naptowne glaciation

10. Paleogeography of eastern and northern Cook Inlet region during Skilak stade of Naptowne glaciation

11. Paleogeography of eastern and northern Cook Inlet region during Elmendorf stade of Naptowne glaciation .....

2. Features of latest Naptowne and Holocene ages in Turnagain Pass area .... 11

13. Distribution of silt and clay with depth in soil profile on crest of latest Naptowne moraine near Stop 1 in Turnagain Pass

14. Massive failure in bedrock above Tern Lake near Stop 2 .

15. Typical features of landslides in bedrock.

16. Pollen percentage diagram for peat section near Tern Lake, central Kenai Mountains 16

17. View west from MP 40.7, Sterling Highway, of Langille Mountain and Shaft Creek valley, a classic hanging valley of Naptowne glaciation (Moosehorn stade)...

9. Locations of profile E-NW (fig. 20) through upper Kenai River valley to Jean Lakes area and figure 23

20. Profile E-NW of highest ice level during Moosehorn stade of Naptowne glaciation from lower Quartz Creek to Jean Lakes area...

1. View west from outcrop above MP 44.9, Sterling Highway, of Round Mountain

22. View north from MP 49.4, Sterling Highway, of narrow chute of Kenai River through cobble-boulder lag that armors river bed....

23. Paleogeography of Juneau Lake-Swan Lake area during Elmendorf stade of Naptowne

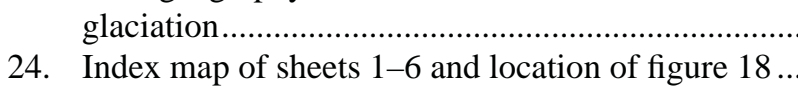

25. Distribution of five vegetation-cover classes in the western Kenai Mountains. 28

26. Relation of vegetation and topography in the Mystery Hills, western Kenai Mountains 29

27. View northwest from MP 58.6, Sterling Highway, of Hideout Hill 
28. Summary of pollen percentage diagram for Hidden Lake core.

29. Comparison of vegetation histories reconstructed from section collected near Tern Lake and core taken from Hidden Lake.

30. View west from east landing at Skilak Lake, showing row of erratic boulders and blocks pushed into place by drifting lake ice below highest summer lake level

31. Sketch of physiography and deposits along lower Kenai River downstream from

Skilak Lake outlet

32. Gravel megaripples preserved in the Kenai River below Skilak Lake outlet......

33. Sketch of physiography and near-surface stratigraphy in Sterling area.

34. Early evolution of lower Kenai River just after culmination of Moosehorn advance

35. Relations of outwash terraces of lower Kenai River set and moraines of the

Skilak Lake (SL) lobe

36. Stratigraphic section through deposits of Sterling Terrace at Sterling................................................ 43

37. Sandy slackwater rhythmites in Skilak-age terrace of lower Moose River ......................................... 44

38. Locations of sites discussed in text relative to field trip stops in northwestern Kenai Peninsula lowland

39. Pollen and spore percentage diagrams for Paradox Lake cores.......................................................... 46

40. Charcoal accumulation rates and inferred wildfire frequency for Paradox Lake cores .......................... 47

41. Evolution of climate and vegetation in the Paradox Lake area, northcentral Kenai

Peninsula lowland.

42. Magnetic susceptibility, loss on ignition, biogenic silica, and pollen composition of composite core from Discovery Pond

43. Sketch of Jigsaw Lake profile showing shoreline terraces relative to lake-sediment core collected in 2001 A.D.

44. Profile of inferred depth to water table based on transfer-function analysis of testate ameobae in peat core collected in cove of Jigsaw Lake

45. Evolution of sandy meltwater complex in vicinity of Scout Lake, northcentral Kenai

Peninsula lowland

46. Sketch of physiography and geology at crossing of Soldotna Creek by Sterling Highway ........

47. Sketch of physiography and geology of middle to late Moosehorn deposits in vicinity of Mackeys Lakes, westcentral Kenai Peninsula lowland .....

48. Sketch across valley of lower Kenai River in Soldotna area, showing general physiography and geologic relations

9. Sketch of physiography and stratigraphic relations in vicinity of Sterling Highway bridge at Soldotna

50. False-color, infrared aerial photograph showing lower Slikok Creek in vicinity of diversion elbow near Sterling Highway.

51. Possible evolution of lower Slikok Creek to form diversion elbow and produce Slikok Creek

fan on Sterling Terrace in late Killey stade.

52. Sketch across valley of lower Kenai River showing physiographic and stratigraphic relations ............ 59

53. Section through braidplain deposits exposed in coastal bluff between Kenai and East Foreland .......... 61

54. Building destroyed by retreat of sand-rich coastal bluff in Salamatof area........................................... 62

55. Typical cross section through east coast of Cook Inlet in Nikiski area, northern Kenai

Peninsula lowland

56. Possible evolution of lower Swanson River

57. Numerous large erratics deposited by glaciers from west side of Cook Inlet in Captain Cook

State Park, northwestern Kenai Peninsula lowland

58. Concretions formed in lake beds northeast of Captain Cook State Park and found in nearby tidelands

59. View west of eroding river bluff at Kenai, showing glacioestuarine deposits of late Moosehorn and Killey stades.

60. Stratigraphy exposed in bluff of lower Kenai River at mouth of Ryan's Creek in Kenai ...................... 69

61. Depositional processes and sediments near a calving tidewater glacier or ice shelf .............................. 70

62. Map of vertical tectonic displacement caused by the great Alaska earthquake of 
March 27, 1964

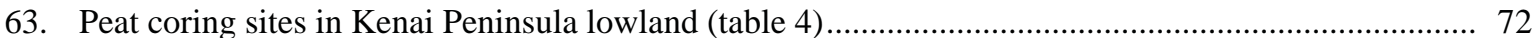

64. Basal peat ages from Kenai Peninsula lowland, arranged from north to south ...................................75

65. Histogram showing germination ages of young black spruce in wetlands in western

Kenai Peninsula lowland.

66. Changes in vegetation cover at Browns Lake, central Kenai Peninsula lowland .............................. 77

67. Changes of moisture/vegetation status at 1,113 random points in Kenai Peninsula lowland, as assessed on aerial photographs

68. Spatial changes of water bodies in the Swanson River, Mystery Creek, and Tustumena Lake areas .... 78

69. Physiography and near-surface geology of uplifted Kalifornsky Glacioestuarine Terrace .................. 79

70. Stratigraphy exposed in gully walls and coastal bluff near MP 10.9, Kalifornsky Beach Road ........... 80

71. Terminal area of Tustumena Glacier, showing physiography and ages of moraines.......................... 82

72. Evolution of topography in southern Kenai Peninsula lowland ....................................................... 85

73. Glacier-impounded lakes in Clam Gulch-Anchor River lowland, southern Kenai Peninsula lowland 86

74. Histogram of fire frequency in southern Kenai Peninsula lowland determined from soil charcoal compared to glacial intervals in southern Kenai Mountains

75. Histogram of mean fire return intervals (MFI) between wildfires in white/Lutz spruce and black spruce related to outbreaks of spruce bark beetles.

76. Standard deviations from mean summer temperatures at Homer, Alaska, related to frequency and intensity of bark beetle attacks in southern Kenai Peninsula lowland.

77. Summary of release pulses in white and Sitka/Lutz spruce in western Kenai Peninsula and

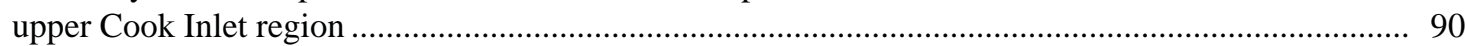

78. Physiography and stratigraphy of lower Anchor River valley ............................................................ 91

79. Typical section in coastal bluffs of southern Kenai Peninsula lowland............................................... 92

80. Formation of Homer Spit as a submarine terminal moraine.............................................................. 95

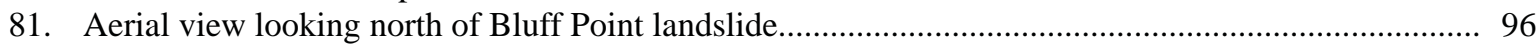

82. Summary of vegetation histories documented at Homer Spit and Circle Lake sites near Homer.......... 98

83. Map of glaciers in southern Kenai Mountains ..................................................................................... 100

84. Summary diagram showing minimum dates of moraines of land-terminating glaciers in southern Kenai Mountains

85. Forefield of Grewingk Glacier, southern Kenai Mountains, showing (A) distribution of Holocene moraines and flood-related features and (B) cross section through landslide source area and body......

86. Changes in thickness of Harding Icefield based on comparison of elevations of 1950-era topographic maps and airborne laser altimetry profiles.

\section{SHEETS}

(in envelope)

Sheet 1. Paleogeographic map of Skilak Lake-Hidden Lake area, northeastern Kenai Peninsula lowland, Alaska

2. Paleogeographic map of Sterling-Skilak Lake area, northcentral Kenai Peninsula lowland, Alaska

3. Paleogeographic map of Kenai-Soldotna-Kasilof area, westcentral Kenai Peninsula lowland, Alaska

4. Paleogeographic map of Kenai-Nikiska area, northwestern Kenai Peninsula lowland, Alaska

5. Paleogeographic map of Kasilof-Clam Gulch area, westcentral Kenai Peninsula lowland, Alaska

6. Paleogeographic map of Anchor Point-Homer area, southwestern Kenai Peninsula lowland, Alaska 


\section{A GUIDE TO THE LATE QUATERNARY HISTORY OF NORTHERN AND WESTERN KENAI PENINSULA, ALASKA}

by

Richard D. Reger ${ }^{1}$, Alfred G. Sturmann², Edward E. Berg ${ }^{3}$, and Patricia A.C. Burns ${ }^{2}$

INTRODUCTION

More than four decades have passed since T.N.V. Karlstrom published his pioneering glacial history of the Cook Inlet region, and yet much of the information he released remains useful today. Karlstrom was an astute field observer and took meticulous field notes, and his geologic cross sections, although reinterpreted today in the light of more information, still provide important data that support these reinterpretations. His hand-drawn physiographic map (Karlstrom, 1964, sheet 3) clearly illustrates landforms that are key to understanding the complex history of this region.

We have learned much in the past $30+$ yrs of investigations in the northwestern Kenai Mountains and Kenai Peninsula lowland. Many new concepts of the glacial history have been published without supporting details and data in venues that are not widely circulated (Reger and Pinney, 1996, 1997; R.D. Reger, 2004), and we believe that a more accessible and complete documentation is timely. Much in this guidebook will be told for the first time in print, although we have led many field trips to examine the evidence. In this volume, we discuss a wide variety of landforms and related processes, including glaciated valleys, massive rock failures, moraines, lake deposits and shorelines features, diversion channels, outwash fans and terraces, braid deltas and braidplains, glaciomarine deposits and coastal terraces, volcanoes, estuarine deposits and effects of land-level change, coastal-bluff stratigraphy, modern beach features, and tsunami hazards. Multi-disciplinary Quaternary scientists will find much that is familiar and innovative, like studies of salinity-sensitive diatoms to assess small land-level changes caused by past earthquakes, and evaluations of past climatic change (Holocene glacial, wildfire, and insect-infestation histories, treeline and lake-level fluctuations, using testate amoebae to evaluate variations of water table levels, evolution of past plant communities based on pollen and spore contents of sediment cores from lakes, ponds, and fens). Two of our primary goals are to emphasize the broad scope of continuing and new research in this fascinating region and to identify some of the participants. Along the way, we will note unresolved issues that warrant further research.

In pursuit of these goals, we will visit 14 localities in the northern Kenai Mountains and western Kenai Peninsula and suggest other sites that display evidence of the last major glaciation and subsequent events and present opportunities to discuss the glacial, fluvial, lacustrine, marine, seismic, volcanic, vegetation, archeological, and fire and insect histories (fig. 1). We will end with a 6-mi (9.6-km) hike through the scenic coastal rain forest on the south side of Kachemak Bay to investigate fresh evidence of a huge October 1967 rockslide-generated flood from the terminal lake of Grewingk Glacier.

For the initial several miles we will be driving through the beautiful northern Kenai Mountains, which are part of the Chugach Terrane. These complex Mesozoic rocks are very well described in other guidebooks (Winkler and others, 1984; Sisson, 1985; Lethcoe, 1990; Karl and others, 1997a; and Winkler, 2000) and will not be discussed in our guidebook.

\section{ACKNOWLEDGMENTS}

This guidebook would not have been complete without the help of several colleagues, many of whom reviewed early drafts of parts of the manuscript and offered constructive suggestions that greatly improved the final draft. Tom Ager, Scott Anderson, Allana DeRuwe, Roman Dial, Feng Sheng Hu, Miriam Jones, Darrell Kaufman, Kacy McDonnell, and Dorothy Peteet graciously provided published and unpublished information on vegetation and fire histories, and Edward Mitchell and Keiko Kishaba allowed us to incorporate preliminary results of their testate amoebae studies. Dave Nyman, Goeff Coble, Rick Wood, and Adinda Demske shared subsurface data for the Nikiski, Kenai, Soldotna, Sterling, Anchor Point, and Homer areas. Doug Reger and Bill and Karen Workman supplied published and unpublished information on the cultural history of

${ }^{1}$ Reger’s Geologic Consulting, P.O. Box 3326, Soldotna, AK 99669 (DGGS retired)

${ }^{2}$ Alaska Division of Geological \& Geophysical Surveys, 3354 College Road, Fairbanks, AK 99709-3707

${ }^{3}$ U.S. Fish and Wildlife Service, Kenai National Wildlife Refuge, P.O. Box 2139, Soldotna, AK 99669 
the Kenai River system, the significance of the Clam Gulch site, and the complex archeology of Kachemak Bay, and reviewed the archeology sections. Steve Baird contributed information on beach erosion in the Homer area. Rod Combellick provided unpublished information about his sample locality in Turnagain Pass.

We acknowledge with respect and considerable appreciation all the assistance we received during our numerous field and laboratory investigations by too many colleagues to list here. Mark Laker of the Kenai National Wildlife Refuge staff prepared the map of peat core locations. Nora Foster (University of Alaska Fairbanks Museum) identified barnacle remains collected from glacioestuarine sections at Kenai and Kalifornsky. Microfossils in the Kalifornsky and lower Kasilof River sections were identified by Micropaleo Consultants, Inc. Elizabeth Wasserman helped arrange our stay at Karen A. Hornaday Hillside Park in Homer and the boat trip to

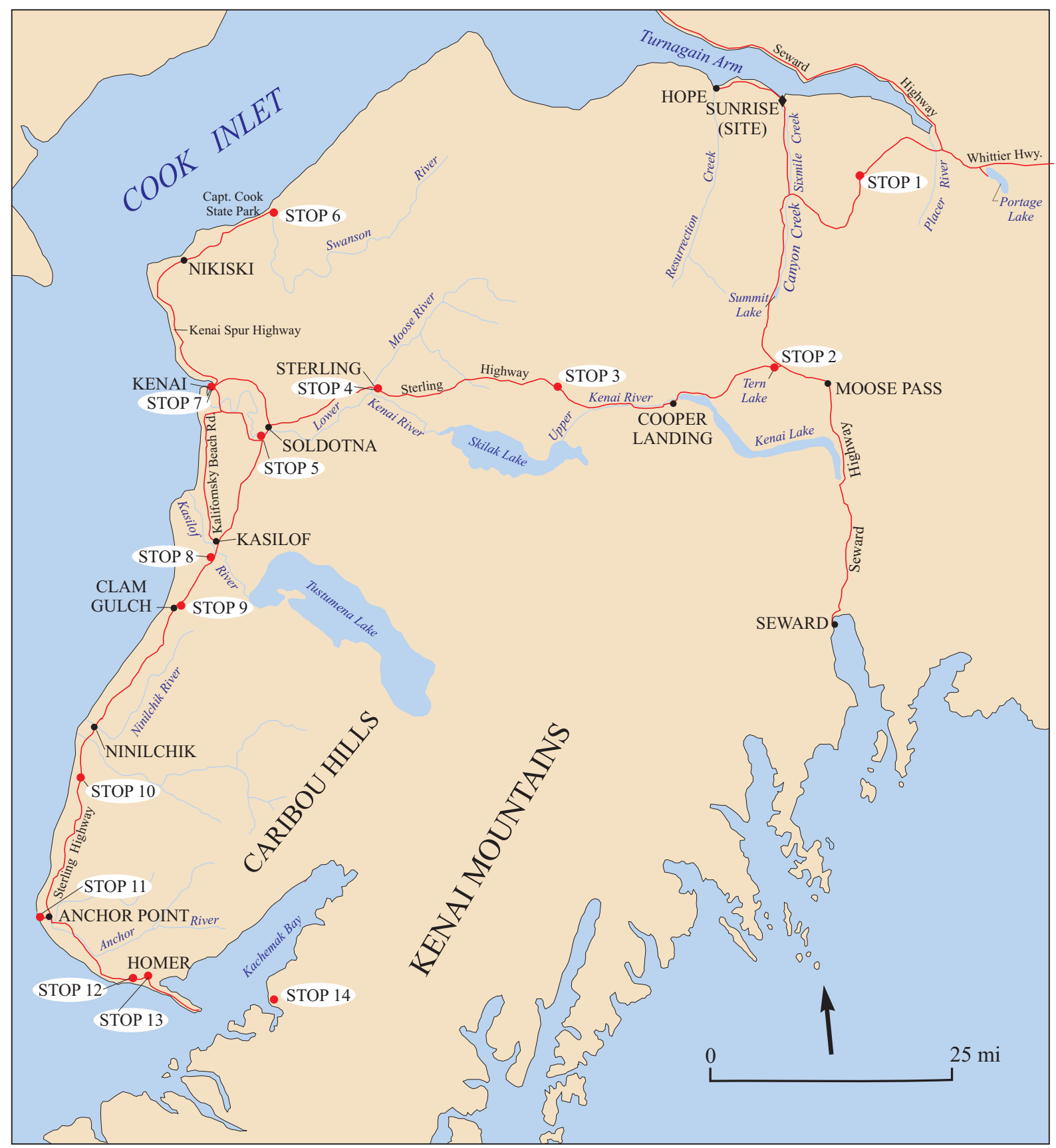

Figure 1. Map of Kenai Peninsula showing locations of geographic features and field-trip stops. 
Halibut Cove. Tom Ager (USGS) and De Anne Stevens (DGGS) accepted and ably completed the considerable task of reviewing this guidebook over a long weekend and several weather days in the field. Both offered very thoughtful, constructive suggestions that considerably improved our presentation and we greatly appreciate their efforts.

We particularly thank Bob Swenson, State Geologist and Acting Director of the Alaska Division of Geological
\& Geophysical Surveys (DGGS), for supporting publication of this guidebook. We greatly appreciate members of the DGGS staff who worked on the critical tasks of preparing the many sheets and figures, editing, and completing the countless other tasks that converted a draft manuscript into final publication form in an impossibly short time. Thank you, Joni Robinson, Sharon Hansen, and Paula Davis.

\section{GLACIAL HISTORY}

Our field trip route traverses mountainous and lowland terrains that were shaped by the last major glaciation, although evidence of earlier glaciations is also present in the region. At the climax of the last major glaciation, roughly 23,000 years ago, most of southcentral Alaska was buried beneath the Cordilleran ice sheet, and equilibrium-line altitude in the Kenai Mountains is estimated to have been $\sim 300$ to $\sim 700 \mathrm{~m}$ ( $\sim 985$ to $\sim 2,300$ ft) lower than today (Mann and Peteet, 1994) (fig. 2). On the Kenai Peninsula, small ice-free refugia existed in the northwestern Kenai Mountains, in the upland between Skilak Lake and Tustumena Lake, and in the
Caribou Hills (Karlstrom, 1964). During that time, inland-moving air masses from the North Pacific Ocean brought abundant moisture to the Kenai Mountains, where heavy snowfalls in response to orographic lifting produced relatively warm, wet-based glaciers that thickened, coalesced, and flowed seaward onto the exposed continental shelf (fig. 3). In the precipitation shadow on the landward side of the Kenai Mountains, the same northwest-moving air masses, now depleted in moisture, produced much less snow, and glaciers were smaller and thinner, probably more continental in character (colder based), and flowed more slowly into the Cook Inlet

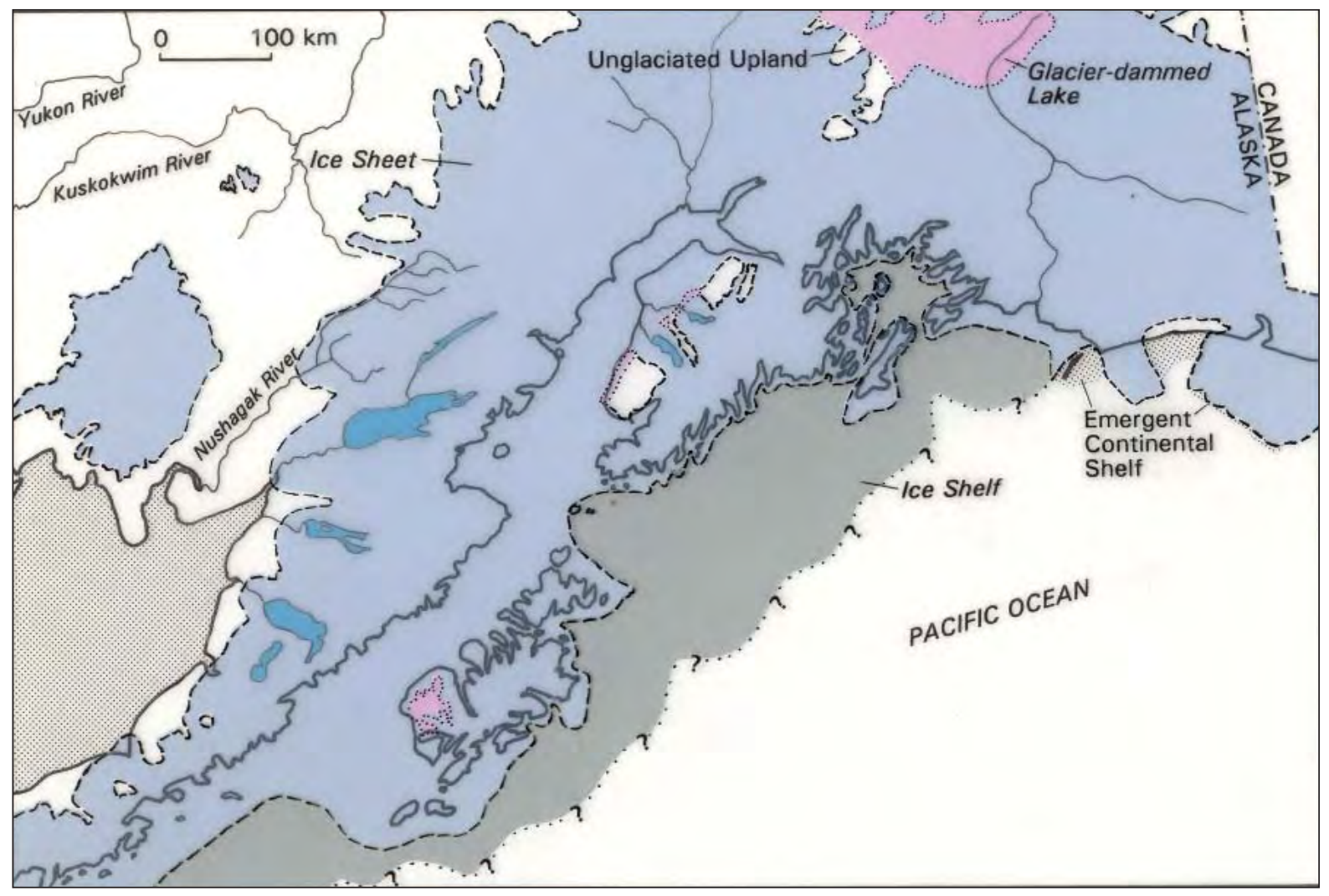

Figure 2. Paleogeography of southcentral Alaska at climax of last major glaciation (modified from Hamilton, 1994, fig. 1). 


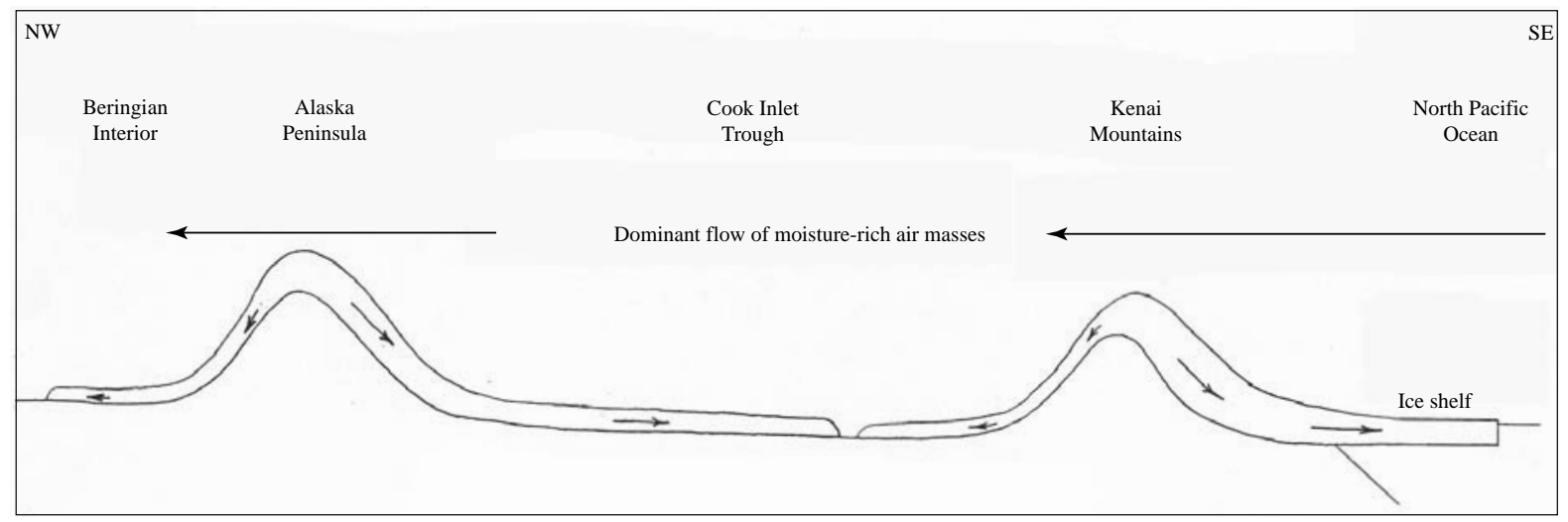

Figure 3. Effects of climatic gradient across Kenai Mountains and Cook Inlet trough at climax of last major glaciation.

lowlands down existing topographic corridors. After crossing over the Cook Inlet trough, where they likely replenished some of their lost moisture, the air masses encountered the high mountains of the Alaska Peninsula and the Aleutian Range, and, in response to orographic lifting, dumped considerable snow annually to form thick, probably wet-based glaciers that coalesced and flowed eastward into the Cook Inlet trough (fig. 4).

\section{SUBDIVISION OF THE LAST MAJOR GLACIATION}

During his pioneering survey of Quaternary deposits in the Cook Inlet region, T.N.V. Karlstrom conceived a four-stade model for the last major glaciation and proposed a type area in the eastcentral Kenai Peninsula lowland. He named this glaciation the Naptowne glaciation after Naptowne Lodge, which existed at that time in the town of Naptowne, now called Sterling (Karlstrom, 1964), and identified terminal moraines in the area as type moraines for the three oldest stades: Moosehorn (oldest), Killey (intermediate), and Skilak (younger) (fig. 5). He also identified a moraine at Tanya Lake, near Tustumena Lake outside the immediate type area, as the type terminal moraine for his youngest (Tanya) stade. Unfortunately, moraines in the type area were not well dated, and correlations with moraines elsewhere in the region were tenuously based on similar surface expression and similar soil development. Subsequent work encountered difficulties reconciling Karlstrom's maps and glacial history with the field evidence and forced reassessment of his model (Schmoll and others, 1972, 1984, 1999; Scott, 1982; Reger and Updike, 1983; Schmoll and Yehle, 1986; Reger and others, 1995). Among the changes suggested is a change in the type area of the youngest stade from Tustumena Lake, where there is no stratigraphic documentation, to the Anchorage area, where convincing evidence of late Naptowne events is well documented and dated by Schmoll and others (1972, 1999) and Reger and others (1995). The youngest stade of the Naptowne glaciation is now termed the Elmendorf stade (Reger and Pinney, 1996, 1997).

\section{ESTABLISHING A CHRONOLOGY}

Mapping glacial deposits in Kenai Peninsula lowland in the past 30+ yrs has utilized 1:25,000-scale metric topographic base maps and 1:63,360-scale false-color infrared aerial photographs, which are a considerable improvement over the 1:63,360-scale topographic maps and 1:40,000-scale black-and-white aerial photography that were formerly available. Landforms were identified and assigned to stades on the basis of their spatial relations to type stadial moraines. Where practical, moraines were physically traced from drainage to drainage across the region. However, where moraines do not join, spatial relations to common landforms provide correlations. For example, terraced remnants of former outwash systems are assigned the ages of the moraines from which they were derived. Glacioestuarine coastal terraces were assigned ages based on the ages of outwash terraces graded to them. In complicated situations, cross-cutting relations were useful for determining relative ages.

Where possible, spatial criteria were supplemented by stratigraphic information. Of historical interest, Karlstrom (1964) recognized a widespread stratigraphic couplet composed of a lower distinctive, discontinuous volcanic ash and an upper brown 'organic' layer in Kenai Peninsula lowland, and he believed the couplet was deposited between the Killey and Skilak advances. Although we now know that the brown 'organic' layer actually includes several brown-weathering Holocene 


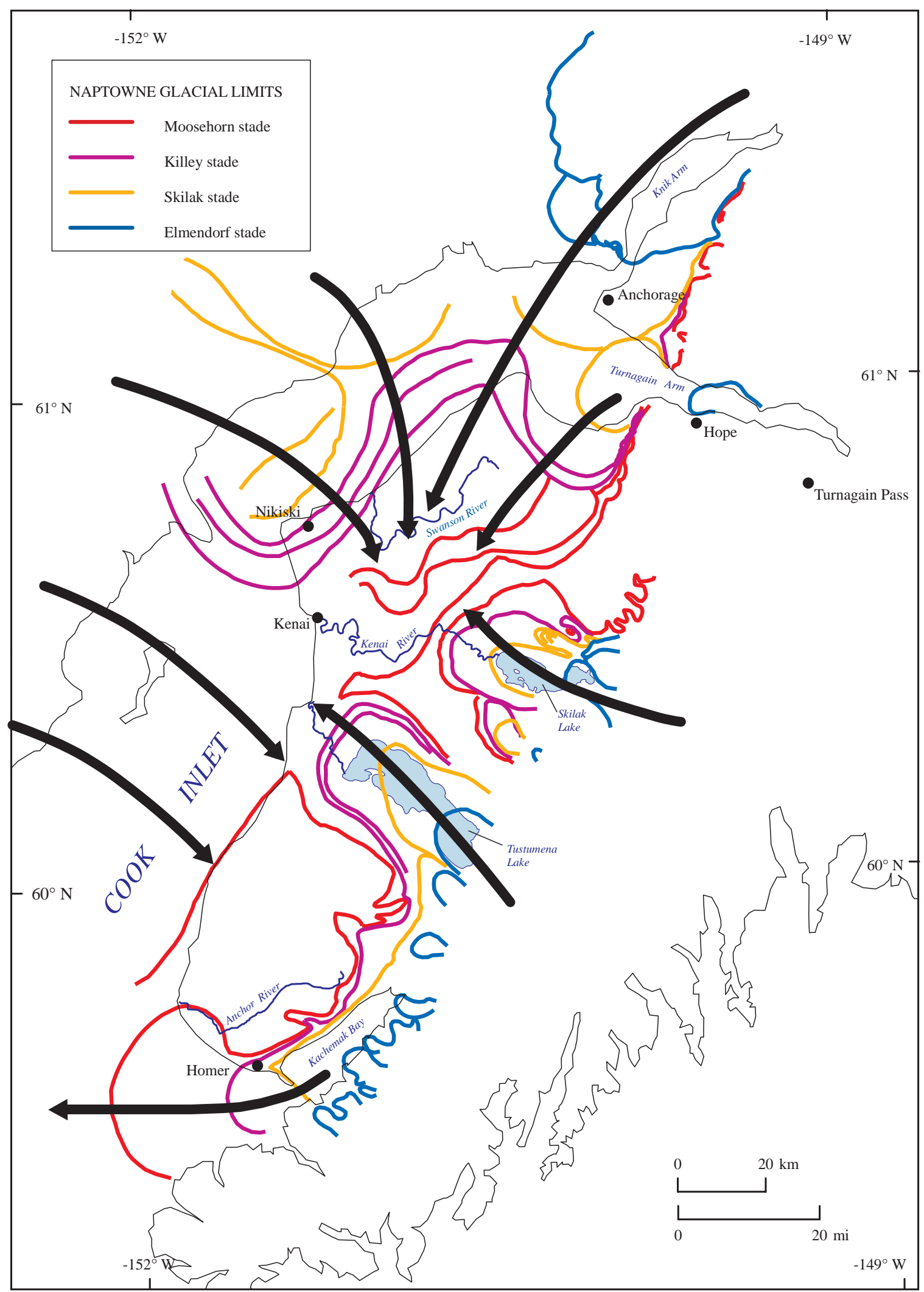

Figure 4. Model of Naptowne glaciation in Cook Inlet region, showing principal ice-flow directions (arrows) inferred from multivariate analysis of magnetic susceptibility and compositions of till pebbles. 
tephras (Reger and others, 1996), key evidence is provided by the older layer of the couplet, which we now identify as the Lethe tephra. Lethe tephra is a distal volcanic ash that was erupted along with proximal pyroclastic flows, lahars, and lahar-runout flows from an unidentified vent near Mount Katmai (Pinney and Begét, 1991). In the type area, the Lethe tephra was deposited during an ice-free interval >12.6 RC kya (14.9 cal kya) (Pinney, 1993). ${ }^{4}$ This distinctive airfall tephra was initially deposited in a lobe on landforms of late Killey age or older across the Kenai Peninsula lowland, where it is documented at more than 30 localities (R.D. Reger, unpublished data). The Lethe tephra has proven to be $>13.7 \mathrm{RC}$ ka (16.4 cal ka) and < 16.0 RC ka (19.0 cal ka) in age and is estimated to have been deposited $\sim 17.8 \mathrm{cal}$ kya. This distinctive stratigraphic marker has been used

\footnotetext{
${ }^{4}$ Uncalibrated radiocarbon years before present are indicated in several ways by the symbols RC ka (kiloannum), RC kya (thousand years ago), RC ya (years ago), and RC yr B.P. (years before present). Calibrated radiocarbon years before present are indicated by cal ka, cal kya, cal ya, and cal yr B.P.
}

to correlate events from Turnagain Arm in the north to Kachemak Bay in the south (Reger and others 1996). However, in seven sections in western Kenai Peninsula lowland a second, younger tephra of Lethe composition is documented, and, in a separate ashfall lobe on the Alaska Peninsula, compositionally equivalent tephras have been dated as young as early Holocene (Riehle and others, 2006), raising questions about use of this tephra for correlation purposes. Nonetheless, correlations in Kenai Peninsula lowland, based on the older, thicker Lethe layer and supported by landform inter-relations and consistent stratigraphic contexts, seem to be reliable. The younger Lethe tephra has been dated at 13 RC ka (Riehle and others, 2006), roughly $15.6 \mathrm{cal}$ ka.

Evidence for the age of the Naptowne glaciation is provided by radiocarbon dating, with caution, however, because of widespread contamination by finely commuted subbituminous and lignitic coals. Many of the initial radiocarbon analyses, although innovative at the time, were crude compared to modern analyses. Early dating procedures demanded considerable carbon,

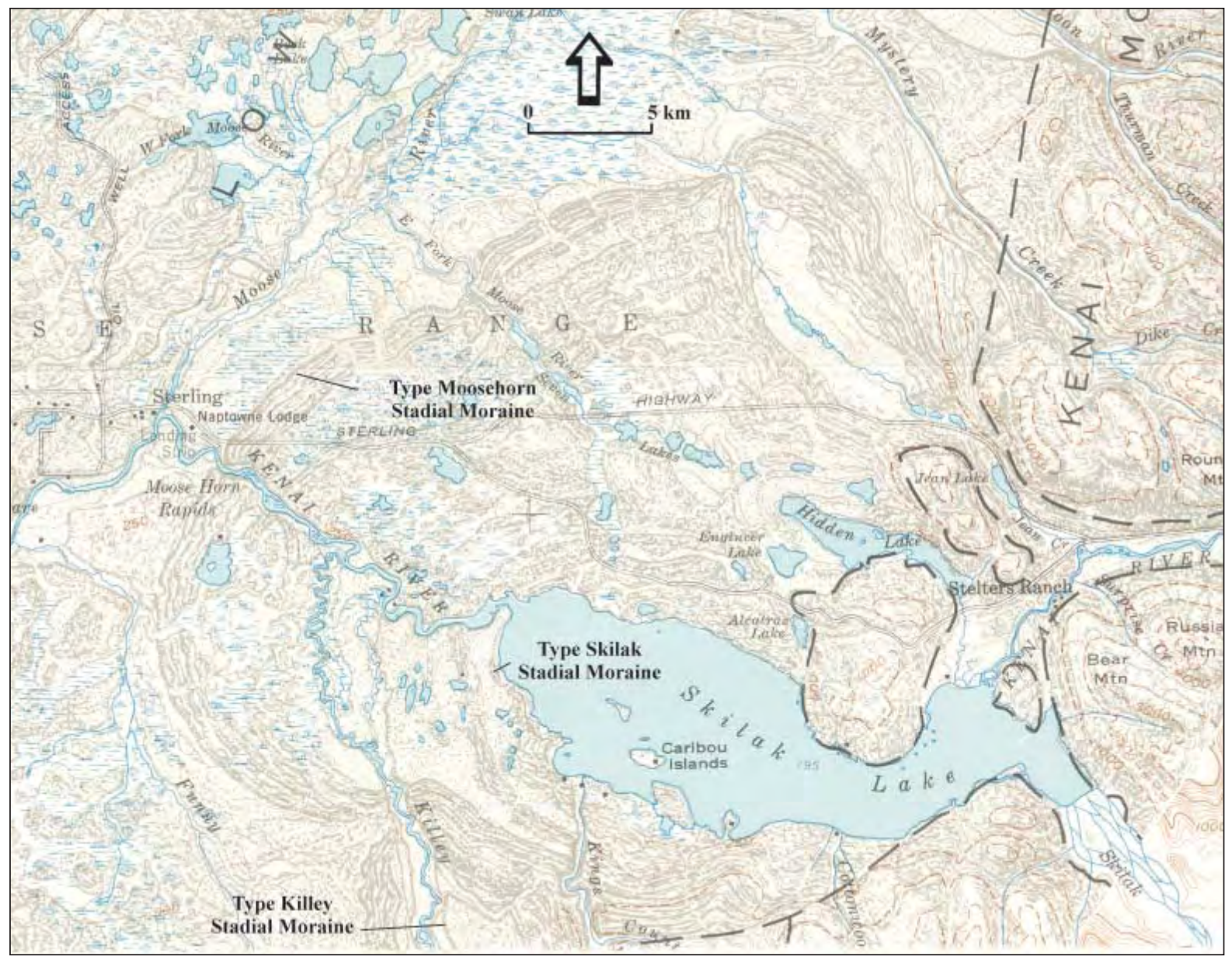

Figure 5. Physiographic map of type area of Naptowne glaciation (extracted from Karlstrom, 1964, sheet 3). 
necessitating bulk sediment samples and yielding questionable results. Improved radiocarbon analyses, such as accelerator mass-spectrometer techniques, have yielded more reliable radiocarbon ages. In our survey of the literature, we soon recognized that radiocarbonbased ages are provided in confusing and inconsistent terms. Early versions of calibration programs provided calibrated means and standard deviations, whereas later versions provided the median ages that are popular now but have a different statistical basis. Where data (means, standard deviations, and sample numbers) are available, we have calibrated original radiocarbon results using the CALIB 5.0.1 program and present our calibrations in terms of median ages (Appendix A). This conversion requires the availability of standard deviation values for each sample, which occasionally limited our efforts when these data are not published. With this program we could not calibrate infinite ages nor several finite ages $>22.0 \mathrm{RC}$ ka. In some cases, calibrated ages were used in reports and diagrams, particularly unpublished diagrams, without indicating which calibration program was used or providing the original means, standard deviations, and sample numbers. In those cases, we use the calibrated ages provided by the authors. Several authors used only radiocarbon ages for general summary diagrams, which provide important information. We have incorporated these diagrams without alteration into this guidebook and make appropriate conversions to calibrated year in related discussions.

Using available data, we have constructed a fairly detailed, although tentative regional chronology for the Naptowne glaciation that, except for the final stade, is unfortunately not solidly constrained by numerous radiocarbon ages (fig. 6). We have looked diligently for samples to constrain the limits of the Moosehorn, Killey and Skilak stades, so far with very limited success. We recognize that this shortcoming provides justification for future testing of our model, which we wholeheartedly support. Time-distance curves in figure 7 compare fluctuations of the principal ice streams in Kenai Peninsula lowland to the best of our knowledge.

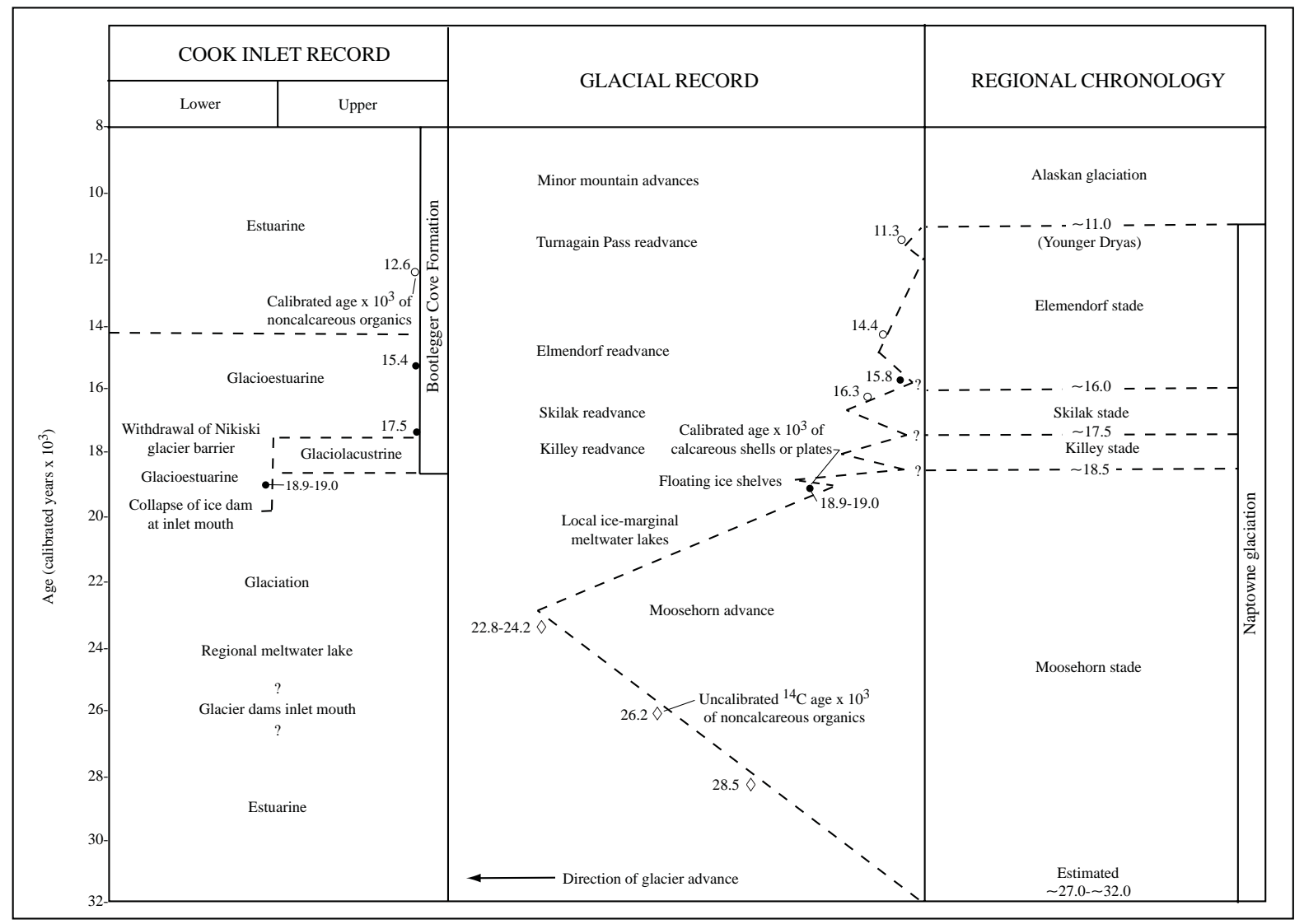

Figure 6. Summary of late Quaternary events in Cook Inlet region. 


\section{SUMMARY OF NAPTOWNE EVENTS MOOSEHORN STADE}

The earliest and longest stade of the Naptowne glaciation was a very complex event (fig. 6). Ice began accumulating in mountain valleys around Cook Inlet 27-32 cal kya and spread out across the floor of the Cook Inlet trough to reach maximum positions $\sim 23 \mathrm{cal}$ kya. This early waxing phase of the Moosehorn stade is not documented in the Cook Inlet region but has been dated in correlative deposits in southwestern Kodiak Island and in the Naknek area, and the radiocarbon ages on our time-distance curve in figure 6 are taken from the work of Mann and Peteet (1994) in those areas. During this expansion phase, ice from the southern Kenai Mountains advanced into the mouth of Cook Inlet and coalesced with ice spreading from accumulation centers, probably in the Fourpeaked Mountain-Mount Douglas and Iliamna Volcano areas to the west. Because worldwide sea level was dropping at this time, the ice barrier in southern Cook Inlet eventually grounded and formed a massive dam behind which meltwaters accumulated to form a lake of regional dimensions in the Cook Inlet basin. Coalesced glaciers expanding from the west side of the basin crossed this lake fairly rapidly, incorporating inlet-bottom sands and abrading exposed Tertiary sandstones, and reached maxima in Kenai Peninsula lowland before smaller, less vigorous ice streams from the western Kenai Mountains reached their maximum limits (fig. 8). ${ }^{5}$ At their maximum extents, Moosehorn glaciers blocked meltwater drainages, impounded an extensive lake at $\sim 100 \mathrm{~m}(\sim 325 \mathrm{ft})$ modern elevation in the Sterling area and diverted the lower Kenai River, and impounded a succession of meltwater lakes up to 125 m ( 410 ft) modern elevation in the southern Kenai Peninsula lowland. Stratigraphy in the Anchor Point area documents the advance of ice from Kachemak Bay into the large southern lake basin.

In response to climatic change after the climax of the Moosehorn stade, the greatly expanded glacier systems became unstable, thinned, and began receding. As ice fronts withdrew, meltwater lakes in isostatically depressed, local basins along the ice margins kept pace, leaving lake-bottom deposits and discontinuous shorelines as an incomplete record. Two recessional

${ }^{5}$ Moosehorn glacial limits shown in figure 8 delineate general overall extents during this very long interval. Actually, glaciers from different sources fluctuated complexly, and ice was not at the maximum limit at the same time everywhere.

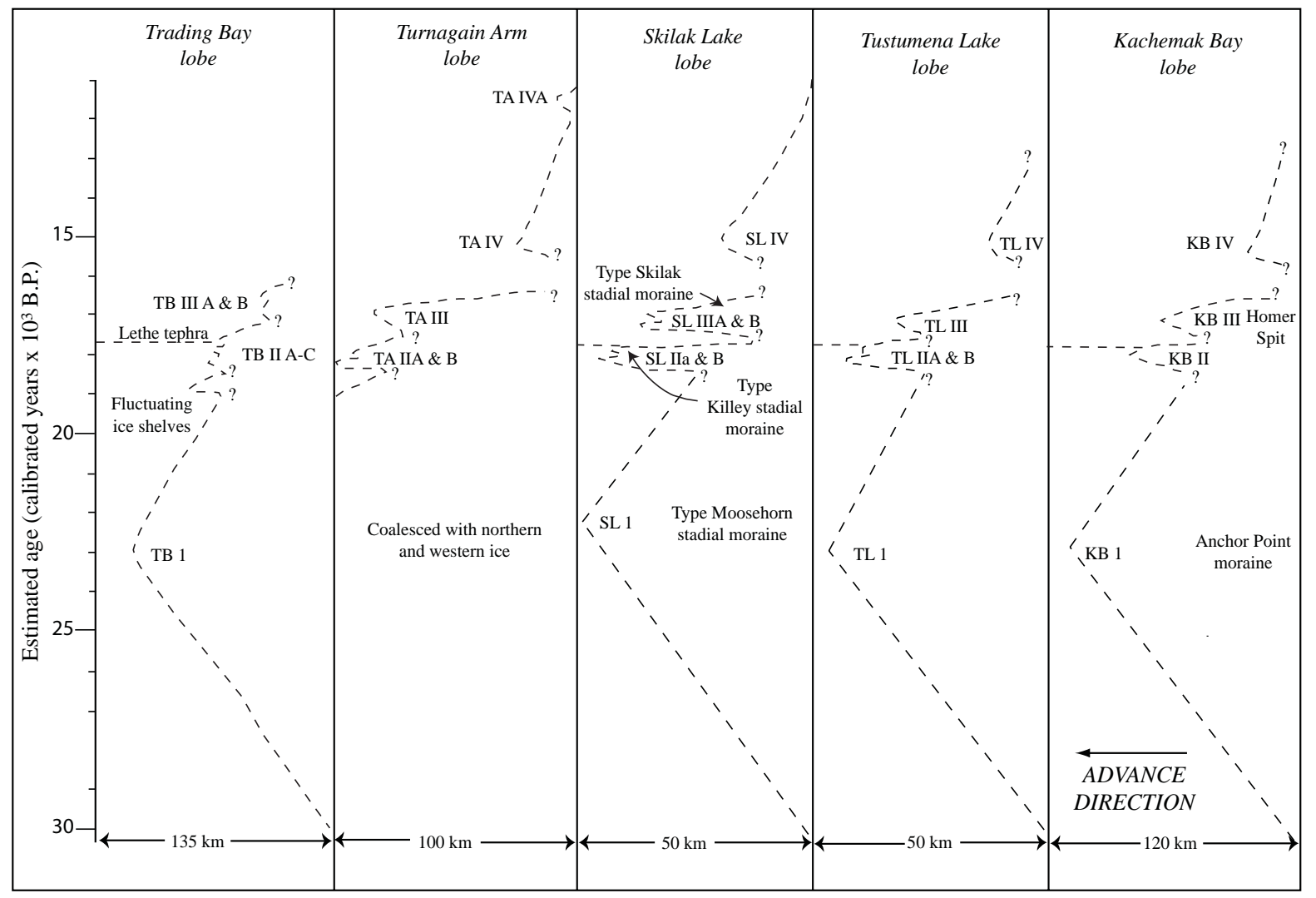

Figure 7. Comparison of time-distance curves of principal ice streams in Kenai Peninsula lowland during Naptowne glaciation. 


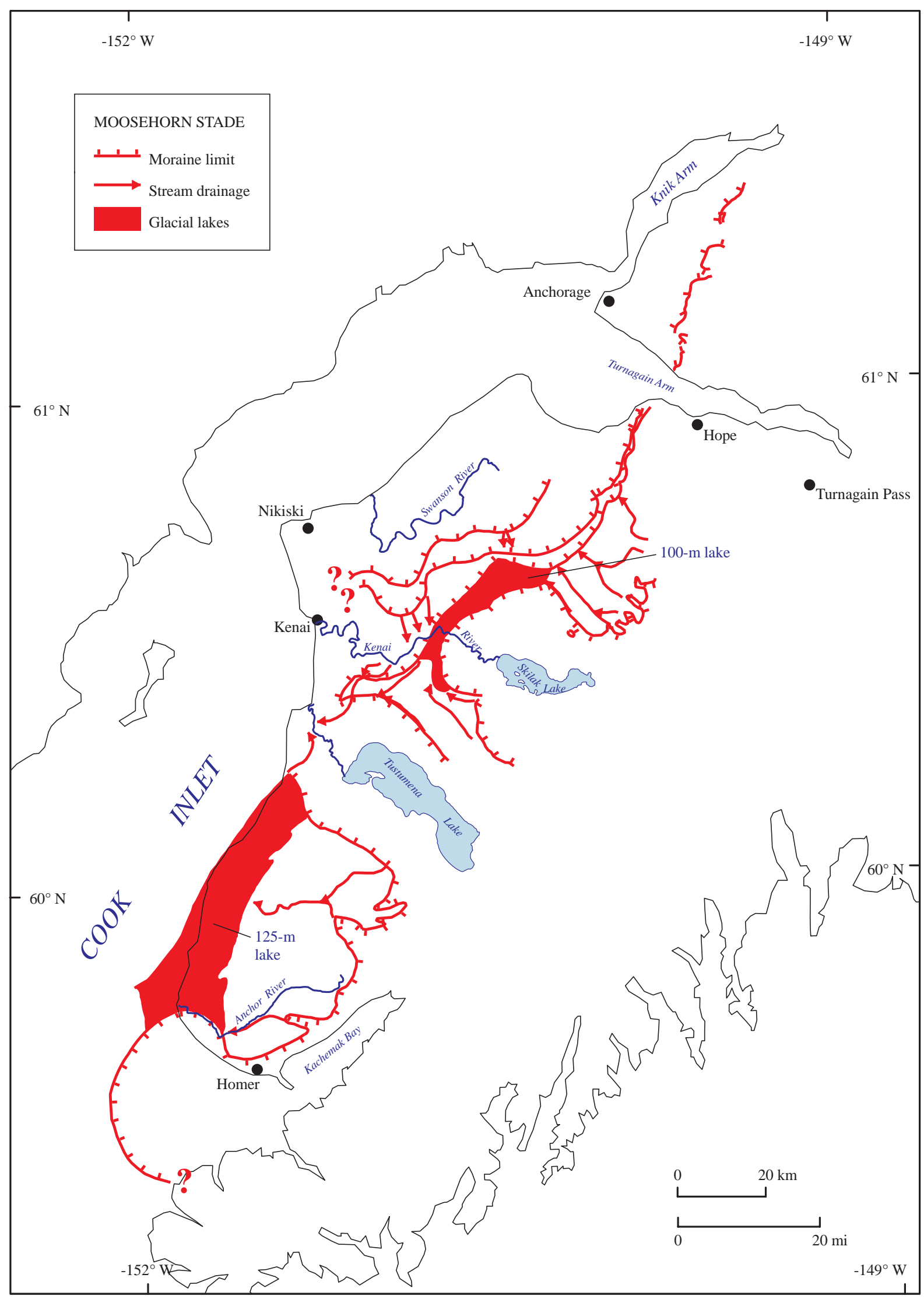

Figure 8. Paleogeography of eastern and northern Cook Inlet region during Moosehorn stade of Naptowne glaciation. 
moraines in northcentral Kenai Peninsula lowland record temporary still-stands or minor readvances late in the Moosehorn stade. The oldest radiocarbon age for the Naptowne glaciation in the Cook Inlet basin is 16.5 RC ka (19.2 cal ka) for calcareous barnacle plates in the coastal bluff at Kenai (Reger and others, 1996). However, this age is not corrected for the marine reservoir effect, which is not known for the Cook Inlet basin, and may be as much as a millennium too old. Regardless, the presence of these barnacle plates bears witness to the breakdown of the glacier dam at the mouth of Cook Inlet and the invasion of marine waters as far north as Kenai by 16.5 RC kya (19.2 cal kya). Evidence in bluffs along lower Kenai River indicates that tabular ice shelves advanced from the northwest through the Kenai area and grounded $\sim 3.1 \mathrm{~km}(\sim 5 \mathrm{mi})$ upriver after $19.2 \mathrm{cal}$ kya at the end of the Moosehorn stade.

\section{KILLEY STADE}

Much of Kenai Peninsula lowland became exposed during the second stade of the Naptowne glaciation, a relatively short interval that began $\sim 18.5$ cal kya and ended 17.5 cal kya (fig. 9). In the north, double end moraines mark advances of Killey age out of Turnagain Arm into an ice-marginal meltwater lake in which were deposited the sands and silts exposed in the coastal bluff in Captain Cook State Park and several miles to the north. From these moraines a braided proglacial drainage system now occupied by an underfit Swanson River extended to the ancestral estuary in the Cook Inlet basin near Kenai. The floor of this estuary is preserved today as the Kalifornsky Glacioestuarine Terrace at $\sim 25 \mathrm{~m}(\sim 80 \mathrm{ft})$ elevation between Kenai and Kasilof. We recognize three ice limits of Killey age in the Nikiski area and the broad braidplain that extended from them to the former estuary in the vicinity of Kenai. The Killey River lobe built the type stadial terminal moraine, and the upper prominent terrace in the lower Kenai River drainage connected this moraine and an equivalent moraine of the adjacent Skilak Lake lobe with the coastal terrace at $\sim 25 \mathrm{~m}(\sim 80 \mathrm{ft})$ elevation. The Tustumena Lake lobe built two end moraines of Killey age and a short outwash system extended northwest to ancestral Cook Inlet. A prominent north lateral moraine was built by the Kachemak Bay lobe and outwash extended down Anchor River during the Killey stade.

\section{SKILAK STADE}

Between 17.5 and 16.0 cal kya, estuarine waters of ancestral Cook Inlet bypassed the glacier dam that formerly existed in the Nikiski area and entered the upper inlet basin, where the dropstone-rich lower Bootlegger Cove Formation was being deposited (Reger and others, 1995) (fig. 10). A readvance of Skilak Lake lobe built the type terminal moraine for the Skilak stade and outwash extended down the lower Kenai River to the former shore of Cook Inlet that is preserved today at $\sim 15 \mathrm{~m}(\sim 50 \mathrm{ft})$ elevation as the lower level of the Kalifornsky Glacioestuarine Terrace. After formation of the inner Killey-age end moraine, Tustumena Lake lobe receded and waves of a terminal lake carved scarps at $\sim 70 \mathrm{~m}(\sim 230 \mathrm{ft})$ elevation along the inner side of the youngest Killey end moraine. A tidal glacier of Skilak age was partially grounded in the northwestern half of Kachemak Bay and built the submarine terminal moraine that forms the foundation of Homer Spit, and a submarine gravel fan formed Archimandritof Shoals where a subglacial stream emerged from beneath the former glacier.

\section{ELMENDORF STADE}

The best documented events during the last stade of the Naptowne glaciation are the near-simultaneous advances of ice from the Chugach Mountains and northern Kenai Mountains down Turnagain Arm to the vicinity of Hope and out of the Matanuska and Knik valleys down Knik Arm to the type Elmendorf terminal moraine north of Anchorage 15.0 cal kya (Reger and others, 1995) (fig. 11). The distribution of the Bootlegger Cove Formation in the upper Cook Inlet region indicates that glacioestuarine waters extended inland several miles up the major drainages of the isostatically depressed southern Susitna River lowland during the Elmendorf stade (Reger and Updike, 1983, sheet 1). Elsewhere, we tentatively assign this final stade of the Naptowne glaciation to glacier positions near the front of the Kenai Mountains but well beyond known Holocene positions identified by Karlstrom (1964) and Wiles and Calkin (1994). Morainal arcs in Turnagain Pass were built by ice advances in the drainages of Ingram, Tincan, and Lyon Creeks just before 11.4 cal kya, probably during the Younger Dryas cold interval. The Naptowne glaciation ended 11 cal kya (fig. 6).

\section{HOLOCENE GLACIATION OF NORTHERN KENAI MOUNTAINS}

Karlstrom (1964) assigned post-Naptowne advances in the northern Kenai Mountains to the Alaskan glaciation, which he subdivided into older Tustumena advances, named after features at the head of Tustumena Lake, and younger Tunnel advances, named after moraines near a tunnel along the Alaska Railroad in the terminal areas of Bartlett and Spencer glaciers in the Placer River valley (fig. 1). In the Placer River area, Tustumena moraines are densely vegetated by a mature coastal forest, which is separated from less-vegetated moraines of the Tunnel advances by sharp trimlines. In 1953 A.D., Karlstrom collected wood samples from beneath tills of Tustumena III and Tunnel I ages in a railroad cut near the terminus of Bartlett Glacier. Dating 


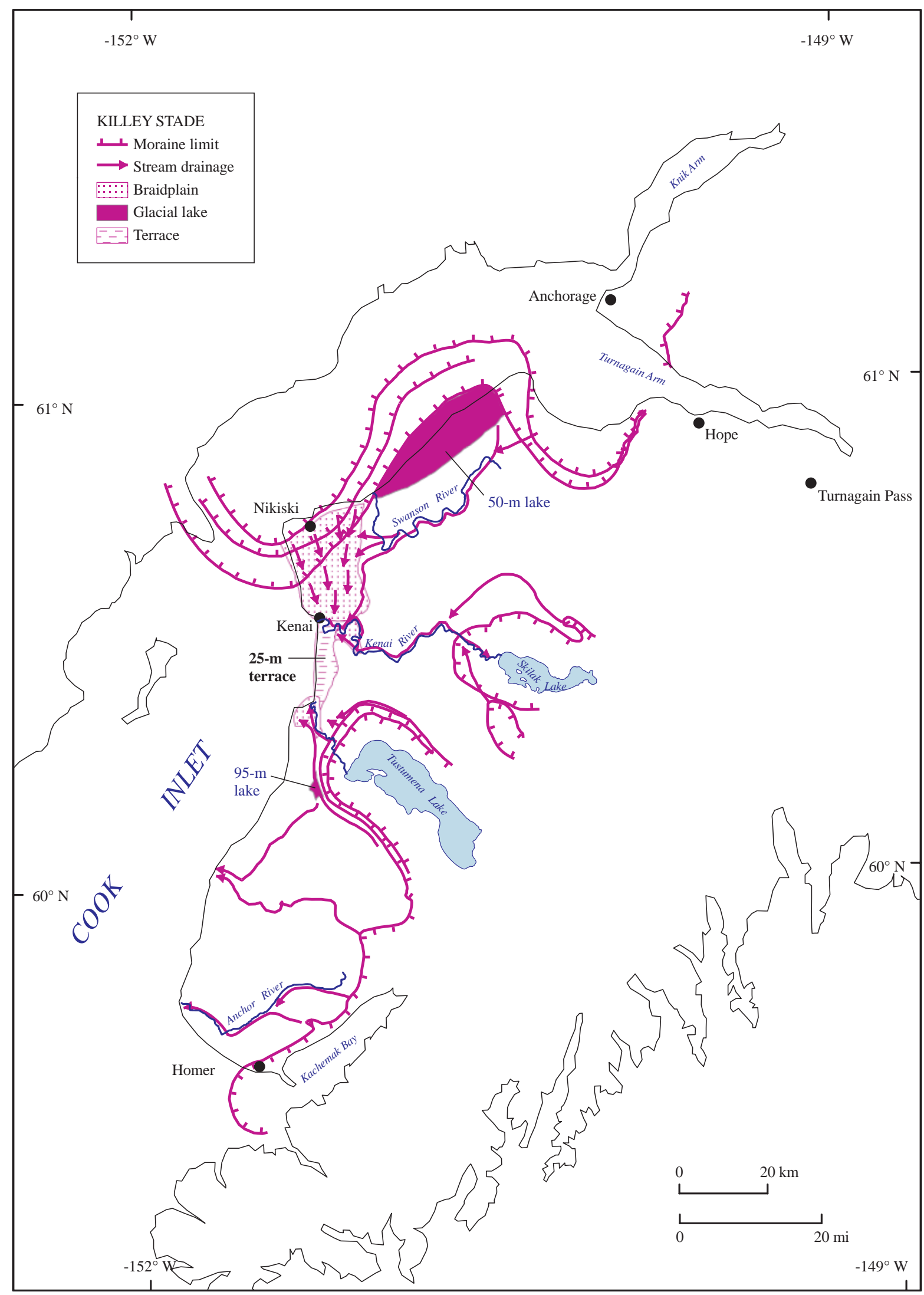

Figure 9. Paleogeography of eastern and northern Cook Inlet region during Killey stade of Naptowne glaciation. 


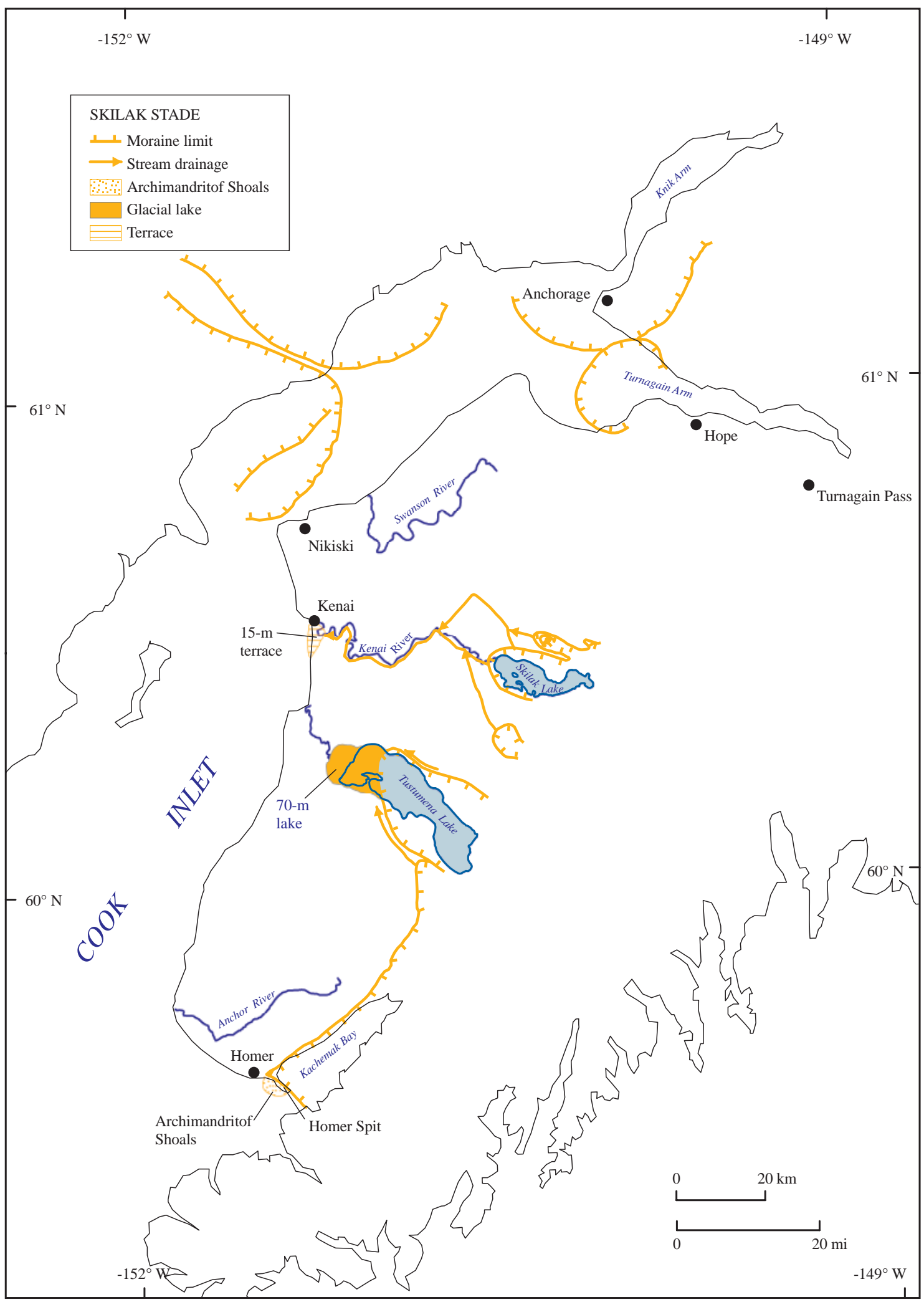

Figure 10. Paleogeography of eastern and northern Cook Inlet region during Skilak stade of Naptowne glaciation. 


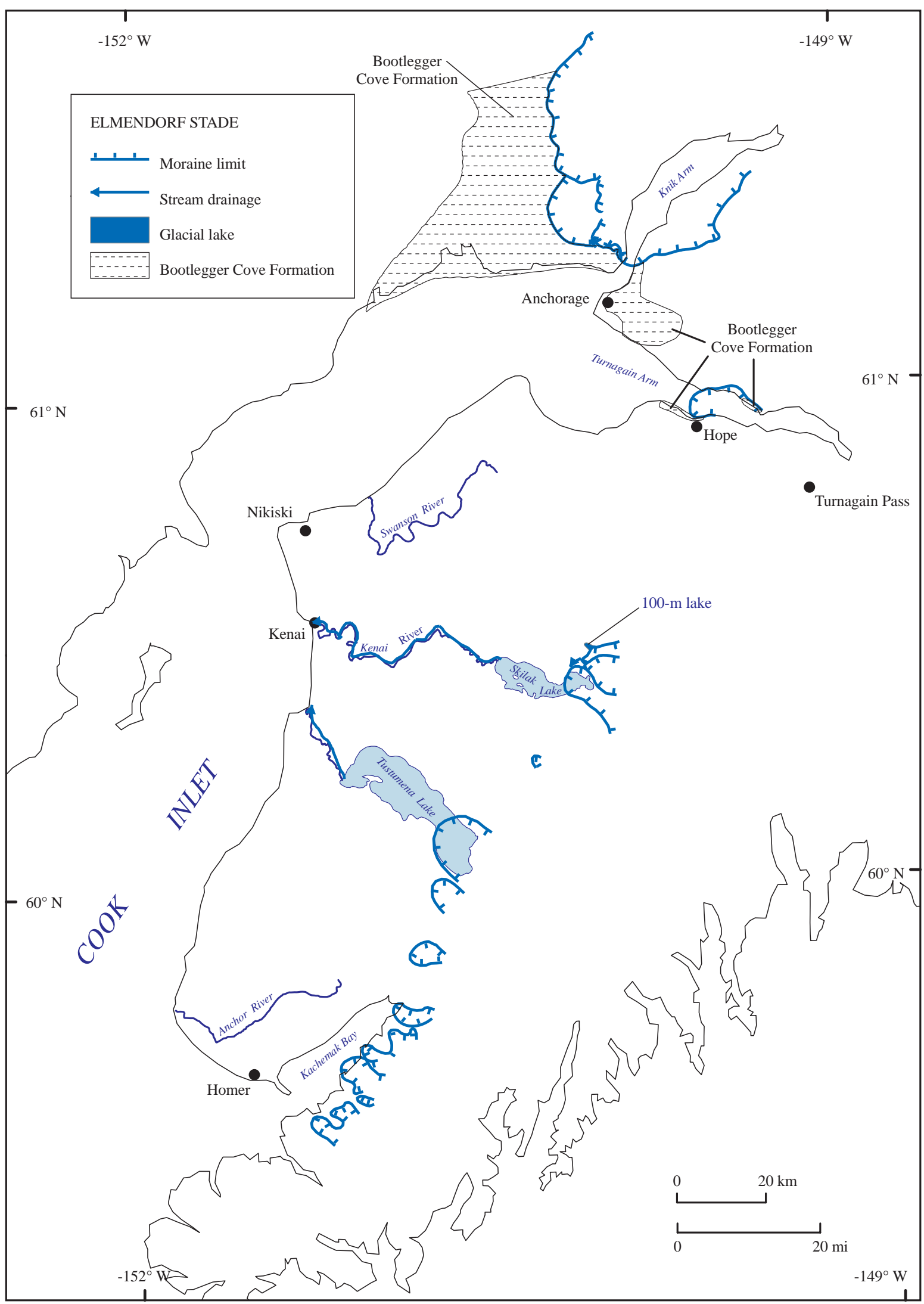

Figure 11. Paleogeography of eastern and northern Cook Inlet region during Elmendorf stade of Naptowne glaciation. 
of these wood samples established maximum-limiting ages for the Tustumena III advance at 2,370 $\pm 70 \mathrm{RC}$ yr B.P. (W-78) (2,445 $\pm 70 \mathrm{cal}$ yr B.P.) and for the Tunnel I advance at 1,385 \pm 200 RC yr B.P. (W-318) (1,296 \pm 200 cal yr B.P.). The younger sample of wood was collected from an in-place stump in a mature forest bed of mountain hemlock, spruce (probably Sitka spruce), and alders that is sandwiched between the two tills.

In 1950 A.D. at nearby Spencer Glacier, Karlstrom (1964, p. 45) collected wood incorporated in till of the Tunnel II advance. This wood dated post-1650 A.D. (L-163G). Historical records and aerial photographs indicate that Spencer Glacier made minor readvances in the late 1850s A.D., in 1916 A.D., between 1931 and 1947 A.D., and between 1947 and 1951 A.D. Since 1951 A.D., Spencer Glacier has thinned and receded.

Karlstrom also (1964, p. 41) assigned tundra-covered moraines in the valley of Palmer Creek, a tributary of Resurrection Creek south of Hope (fig. 1), to the Tustumena advance. There, the till is weathered to depths of 2 to 8 in $(5$ to $20 \mathrm{~cm})$. The Palmer Creek moraines are clearly younger than forested moraines of Naptowne age downvalley and predate much fresher-looking moraines marginal to the small cirque glacier at the head of the valley.

Subsequently, Kris Crossen and others investigated the Little Ice Age history of the Portage Glacier-Portage Pass area. The massive end moraine at the northwest end of Portage Lake (fig. 1) is attributed to the 1890-1910 A.D. advance of Portage Glacier (Mayo and others, 1977; Brown and others, 1987). Crossen (1992) used dendrochronology and lichenometric techniques to estimate the ages of morainal remnants downvalley from the 1890-1910 A.D. moraine at 1852 A.D., 1810 A.D., and pre-1810 A.D. The latter moraine apparently represents the maximum Little Ice Age advance in Portage Valley. Historical accounts indicate that Portage Lake initially developed between 1910 A.D. and 1914 A.D. (Brown and others, 1987). Rates of recession of Portage Glacier have changed considerably from prior to 1914 A.D., when the glacier terminated on land ( 3-5 m/yr [ 10-30 ft/yr]), to between 1914 and 1984 A.D., when the glacier calved into Portage Lake ( 33- 146 m/yr [ 110- 480 ft/yr]) (Crossen, 1992, table 1).

\section{VEGETATION HISTORY}

There are at least 18 late Wisconsin-Holocene pollen chronologies for the northern and western Kenai Peninsula that tell a classic story of new plant colonists arriving from northern and southern sources. During the Killey stade ( 18.5 to $\sim 17.5$ cal kya), raw soil surfaces were exposed across broad areas of Kenai Peninsula lowland, providing abundant sites for colonization by plants. In cold, windy conditions, freshly exposed bedrock surfaces and frost-stirred sterile soils at both inland and coastal sites were initially colonized by a complex herbaceous tundra that apparently survived the climax of the last major glaciation in scattered refugia. The timing of actual colonizations depended on the timing of local deglaciation. The herbaceous tundra consisted of grasses, sedges, forbs, herbs, and heaths with scattered, low shrubs of Artemisia, Betula, and Salix (Ager and Brubaker, 1985; Ager and others, 1985).

Pollen studies indicate that in inland sites, birch shrubs began dominating pioneer plant elements between 13.7 and 10.9 RC kya (roughly between 16.4 and 13.0 cal kya), and this shrub flora persisted until $\sim 10.5$ to $\sim 9.3$ RC kya ( 12.2 to 10.5 cal kya) (Ager and Brubaker, 1985). Fern spores began appearing $\sim 12.8$ to $\sim 11.4$ RC kya ( 15.1 to $\sim 13.2$ cal kya) in coastal sites, where ferns are common floral elements today (Ager, 2000; Ager and Carrara, 2006). Poplars began forming scattered clonal clumps at inland sites $\sim 10.5$ RC kya ( 12.2 cal kya), about the time that alders were moving into coastal sites from the east. Both plants persist in the region today, and alders have moved inland. Boreal spruce and birch arrived in the upper Cook Inlet area $\sim 9.0$ to 8.5 RC kya ( 10.1 to 9.5 cal kya), and within a few decades to centuries spread southward into northern Kenai Peninsula lowland. Sitka spruce and mountain hemlock, which typify coastal rain forests in eastern Turnagain Arm and in the southern Kenai Peninsula lowland today (Viereck and Little, 1972), arrived fairly late, $\sim 3.0$ RC kya ( 2.9 cal kya). Ager (2/27/07 pers. commun.) found traces of mountain hemlock pollen prior to this time but believes that they could represent wind transport from distant sites. A fairly late transitional forest dominated by Lutz spruce, a hybrid of white and Sitka spruce, covers southern Kenai Peninsula lowland south of Tustumena Lake (Ager, 2000). Boreal spruce and birch began invading western valleys in the northern Kenai Mountains from northern Kenai Peninsula lowland $\sim 8.0$ to 6.0 RC kya ( 9.0 to 6.9 cal kya) and perhaps as early as $\sim 3.0 \mathrm{RC}$ kya ( 3.2 cal kya) began mixing with Sitka spruce and mountain hemlock to form a montane forest that is transitional between interior boreal forests and coastal rain forests (Ager, 2001). 


\section{CLIMATE CHANGE}

The recently recognized phenomena of increasing worldwide temperatures and other environmental changes have focused public and scientific attention on changes in global climate, both present and past. Most of the current research in the northern Kenai Mountains and Kenai Peninsula lowland evaluates evidence for climatic change, including proxies for past temperatures and precipitation. In this guidebook we go fairly far afield to draw attention to this ongoing work, pointing out recent results in studies of peat accumulation, sedimentary records (biogenic silica, chironomids, and testate amoebae), treeline fluctuations, changes in vegetation cover and lake levels, wildfire and insect-infestation histories, and Holocene glaciation. These studies provide details that are not generally preserved in the less-than-perfect geologic record, but the same processes occurred in the past, and it is important to understand them and their potential implications for the geologic record.

\section{STOP DESCRIPTIONS AND \\ ROAD LOG \\ STOP 1. TURNAGAIN PASS}

AP 68.4, Seward Highway. ${ }^{6}$ Many well-preserved glacigenic landforms related to the final phase of the Elmendorf stade of the Naptowne glaciation are present in the Turnagain Pass area (fig. 12). Karlstrom (1964, p. 46) reported an age of $\sim 4.5$ RC ka (L-237G) $(\sim 5.1 \mathrm{cal} \mathrm{ka})$ for a peat sample from the lower $15 \mathrm{~cm}$ (6 in) of a 0.9 - to $1.5-\mathrm{m}$ - (3- to 5-ft-) thick kettle filling overlying bedrock and till along the Seward Highway $2.4 \mathrm{~km}(\sim 1.5 \mathrm{mi})$ northeast of this location, providing the first distant minimum age for deglaciation of Ingram Creek valley. Later, Combellick (1984) mapped these features as Holocene in age but then obtained an age of 9.8 RC ka (GX-10649) (11.4 cal ka) for peaty material extracted from a depth of $1.8 \mathrm{~m}(5.9 \mathrm{ft})$ in lake deposits inside a set of nested end moraines in the upper Ingram Creek drainage, demonstrating that the moraines actually represent a latest Elmendorf (Younger Dryas) readvance in the valley of Ingram Creek (Reger and others, 1995). Landform relations indicate that similar nested end moraines in nearby Tincan Creek and Lyon Creek drainages are probably also Younger Dryas in age.

As part of their efforts to evaluate the use of weathering profiles by Miller and Dobrovolny (1959) and Karlstrom (1964) to assign ages to landforms of the Naptowne glaciation in the Cook Inlet region, Reger and others (1996) compared soil profiles near Sterling,

${ }_{6}^{6}$ Field trip mileages along Seward Highway are keyed to green mileposts measured northward from Seward, MP 0.
Kachemak Bay, and Turnagain Arm. Of the seven profiles described, the youngest (one of two profiles in the Turnagain Arm group) is located near Stop 1 at 297 m (980 ft) elevation on a rounded crest in the Ingram Creek suite of nested Younger Dryas moraines (fig. 12). In this profile, development of the spodic (B) horizon is very advanced, as indicated by significant reddening and darkening of B subhorizons compared to the olive gray of the parent till (fig. 13, tables 1 and 2). The magnitude of change in hue in Bhs and Bh subhorizons in this relatively young profile exceeds the greatest color change in the oldest Moosehorn-age soil in the Sterling area, and the B horizon is 7 in $(18 \mathrm{~cm})$ thicker. Silt and clay caps are present in Bhs, Bw, and Cox subhorizons. In the Bw subhorizon, caps are a very bright dark-reddish brown and are moderately thick. Mottling of the Cox subhorizon could be the result of frost action.

This soil profile documents the considerable weathering that has occurred during the 11 millennia or so since the climax of the Younger Dryas readvance in Turnagain Pass. Reger and others (1996) concluded that this strong horizon differentiation reflects the very moist maritime climate of the northern Kenai Mountains, where annual sea-level precipitation averages $53 \mathrm{~cm}$ (21 in) at Hope, $101 \mathrm{~cm}$ (40 in) at Girdwood, and $196 \mathrm{~cm}$ (77 in) at Portage (Ager and Carrara, 2006), and where precipitation rates increase with elevation. Well-developed $\mathrm{Bh}$ and Bhs subhorizons indicate that humic-acid production has been intense beneath the subalpine vegetation. Possible effects of past wildfires on pedologic processes in Turnagain Pass have not been evaluated.

As a result of their comparison of soil development on moraines of different ages, Reger and others (1996, p. 57) urged cautious use of soil-profile development for assigning ages to moraines in the Cook Inlet region. They argued that significant environmental gradients existed in the past and still persist in the Cook Inlet region between coastal, inland, and alpine sites, and that these gradients significantly affect rates of soil formation, compromising the use of soils to date and correlate landforms across the region. Moraines that are known to be the same age based on physiographic and stratigraphic evidence bear very different soils in different areas.

In Turnagain Pass we are situated near the altitudinal limit of the coastal rain forest. Compared to treeline south of Seward Highway, treeline on the north valley wall in this pass is lower because of frequent and extensive snow avalanching. For the next $\sim 5 \mathrm{mi}(8 \mathrm{~km})$, we will drive through a coastal rain forest composed primarily of Sitka spruce, mountain hemlock, and black cottonwood. Then at the crossing of Granite Creek (MP 63.2), with the appearance of the first birch along the highway, we 


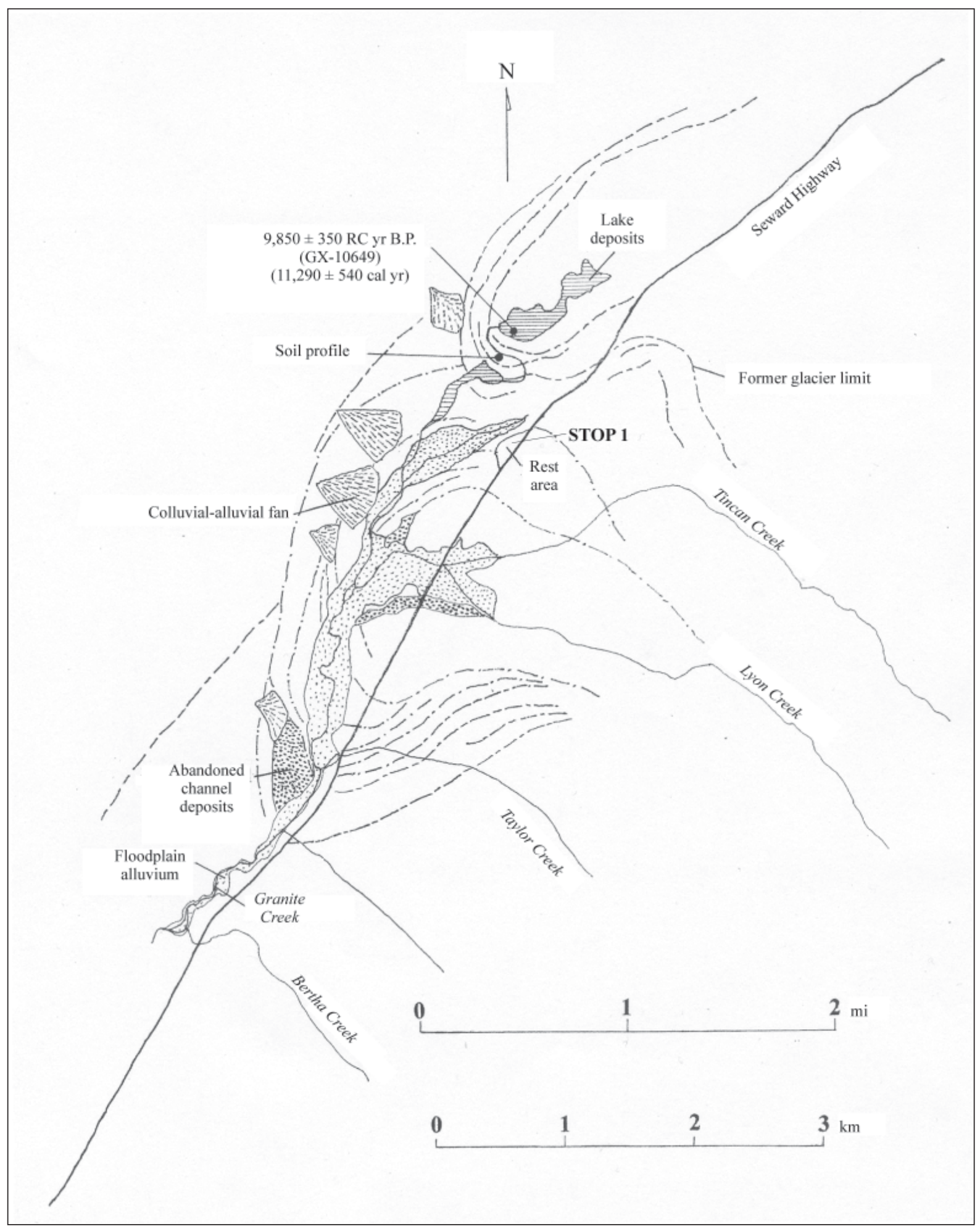

Figure 12. Features of latest Naptowne and Holocene ages in Turnagain Pass area (modified from Combellick, 1984). Stop 1 is located at MP 68.4, Seward Highway. 


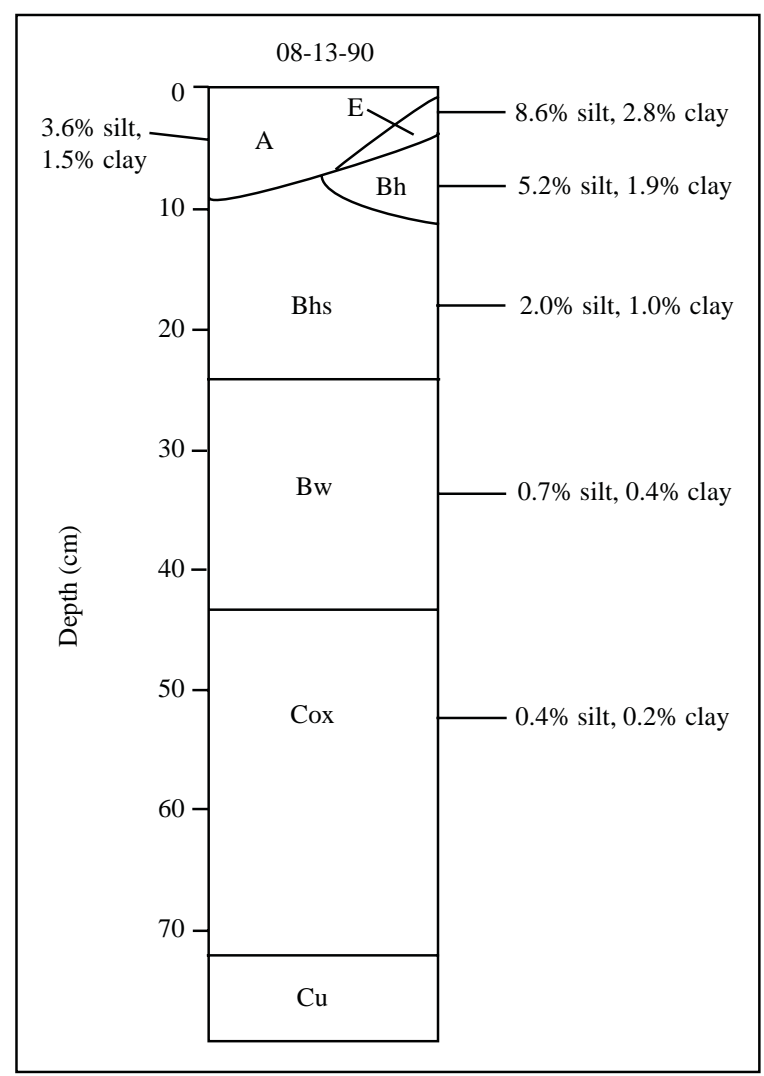

enter a transitional forest of these coastal species mixed with such boreal forest elements as white spruce, birch, and balsam poplar (Ager, 2001). Above the forest is a shrub zone dominated by alders, and alpine tundra and bare rock surfaces are present on upper slopes and ridge crests. Tracks of snow avalanches are common through this part of the northern Kenai Mountains (March and Robertson, 1982).

MP 63, Seward Highway. Stoss and lee slopes of the roche moutonnée south of the highway indicate that ice of the Naptowne glaciation flowed westward through this valley.

MP 61.5, Seward Highway. Crossing of East Fork Sixmile Creek. For the next $\sim 5.2 \mathrm{mi}(8.3 \mathrm{~km})$ the Seward Highway parallels the East Fork, a popular whitewater rafting stream that becomes dangerous where it enters a deeply incised, rock-walled canyon above its confluence with Canyon Creek. Karlstrom (1964, p. 45) reported an age of $\sim 6.8 \mathrm{RC}$ ka (L-237F) (7.7 cal ka) for a wood sample he collected in 1952 A.D. from the base of a 1.2- to 1.8-m- (4- to 6-ft-) thick bog deposit overlying 1.6 to $2.4 \mathrm{~m}$ (6 to $8 \mathrm{ft}$ ) of laminated lake clays at the top of the bedrock canyon wall on the northeast side of East Fork Sixmile Creek. This sample from $3.2 \mathrm{~km}$ ( 2 mi) southeast of the Seward Highway-Hope Road junction provides a minimum age for draining of a late-glacial
Figure 13. Distribution of silt and clay (calculated as percent of <2-mm fraction) with depth in soil profile at $297 \mathrm{~m}$ (980 ft) elevation on crest of latest Naptowne moraine near Stop 1 in Turnagain Pass. Horizons according to Soil Survey Staff (1975) modified by Birkeland and others (1991) and Reger and others (1996, table A2). Horizon O not shown above horizon A. Detailed profile description summarized in table 1.

lake in this area and probably the cutting of the 16.7-m(50-ft-) deep canyon in Valdez Group bedrock.

MP 56.5, Seward Highway. Crossing of Canyon Creek and MP 56.3 junction with side road to Sunrise-Hope historic mining district (Barry, 1997). Canyon Creek, which is deeply incised into slates and metasandstones of the Valdez Group, and Mills Creek, one of its main tributaries, have produced rich bench and channel gold placers since the late 1890s A.D. (Hoekzema, 1985; Kurtak and others, 1997).

We turn south now and for the next $16 \mathrm{~km}$ ( $10 \mathrm{mi})$ ascend a moderate grade to Summit Lake through this scenic glaciated valley. Well-preserved ridge-crest lateral moraines indicate that at least $910 \mathrm{~m}(3,000 \mathrm{ft})$ of glacial ice filled this valley during the climax of the Naptowne glaciation.

MP 48.4, Seward Highway. East of the highway at the confluence of Canyon Creek and Mills Creek and in lower Mills Creek canyon, some of the richest placer ground in the district was discovered (Martin and others, 1915, p. 204-205). When the leaves are off the trees, placer-mine tailings are visible at the mouth of Mills Creek canyon.

MP 47.4, Seward Highway. Lower Summit Lake. 


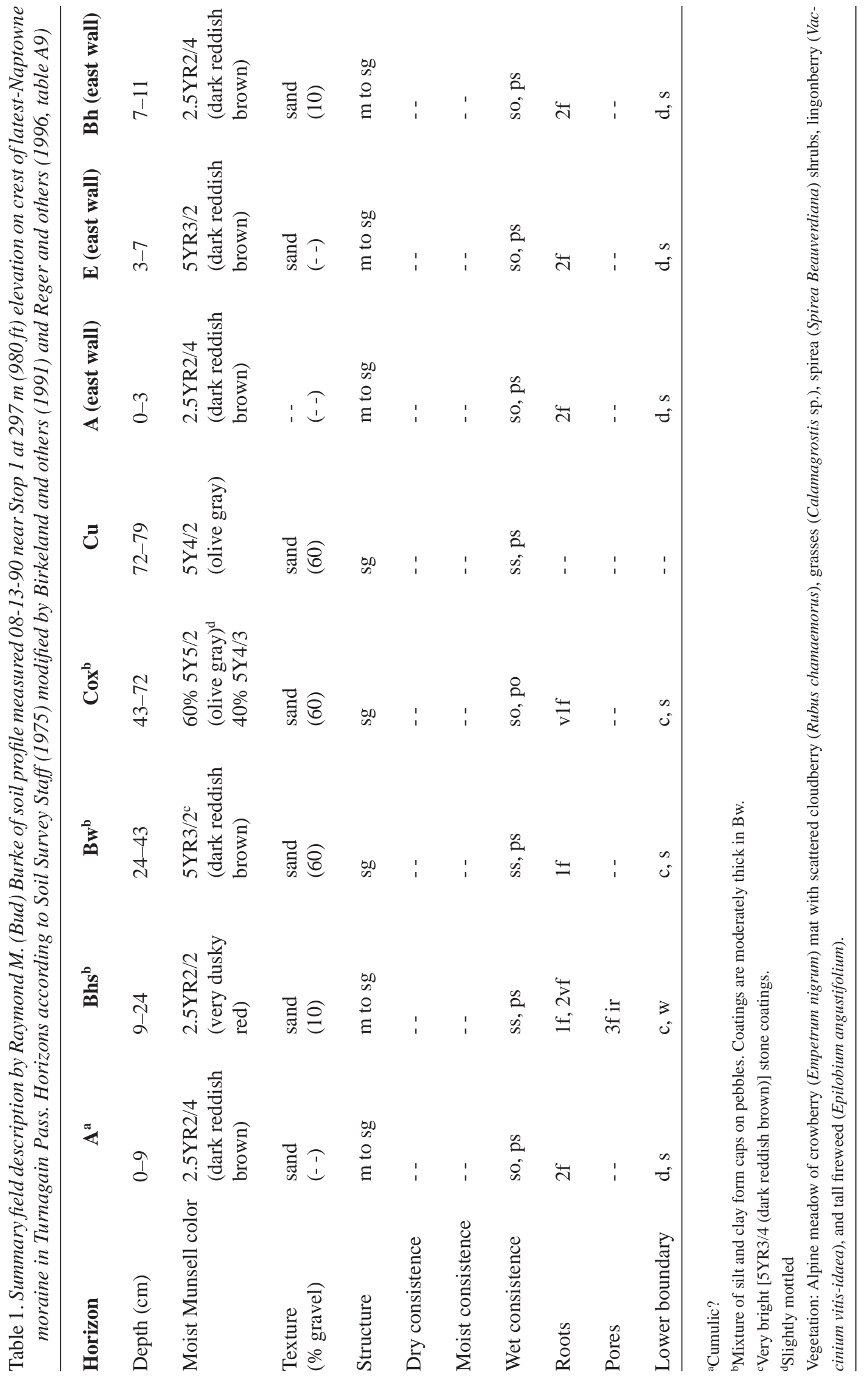


Table 2. Definitions of symbols in summary soil descriptions [Soil Survey Staff (1975) modified by Harden (1982), Birkeland (1984), Birkeland and others (1991), and Reger and others (1996, table A2)]

\begin{tabular}{|c|c|c|c|}
\hline Characteristic & Symbol & Definition & Measure \\
\hline Structure & $\begin{array}{l}1 \\
\mathrm{~m} \\
\mathrm{sg} \\
\mathrm{vl} \\
\mathrm{f} \\
\mathrm{pl} \\
\mathrm{sbk}\end{array}$ & $\begin{array}{l}\text { Few present } \\
\text { Massive } \\
\text { Single grained } \\
\text { Very weak } \\
\text { Fine or thin } \\
\text { Platy } \\
\text { Subangular blocks }\end{array}$ & $\begin{array}{l}\text { Few/dm }{ }^{\mathrm{a}} \\
\text { No peds developed } \\
\text { No article bonding } \\
\text { Very few, indistinct peds } \\
\text { Plates } 1-2 \text { mm, blocks } 5-10 \mathrm{~mm} \\
\text { Particles oriented in horizontal planes } \\
\text { Peds faces round and planar }\end{array}$ \\
\hline Consistence & $\begin{array}{l}\text { lo } \\
\text { so } \\
\text { so } \\
\text { ss } \\
\text { po } \\
\text { ps }\end{array}$ & $\begin{array}{l}\text { Loose (dry and moist) } \\
\text { Weakly coherent (dry) } \\
\text { Nonsticky (wet) } \\
\text { Slightly sticky (weta0 } \\
\text { Nonplastic (wet) } \\
\text { Slightly plastic (wet) }\end{array}$ & $\begin{array}{l}\text { Noncoherent } \\
\text { Powders easily } \\
\text { No adherence } \\
\text { Slight adherence, stretches } \\
\text { No rod forms } \\
\text { Weak rod forms }\end{array}$ \\
\hline Roots & $\begin{array}{l}\text { vl } \\
1 \\
2 \\
3 \\
\text { vf } \\
\mathrm{f} \\
\mathrm{m} \\
\mathrm{co}\end{array}$ & $\begin{array}{l}\text { Very few present } \\
\text { Few present } \\
\text { Commonly present } \\
\text { Many present } \\
\text { Very fine } \\
\text { Fine } \\
\text { Medium } \\
\text { Coarse }\end{array}$ & $\begin{array}{l}\text { Very few/dm } \\
\text { Few } / \mathrm{dm}^{\mathrm{a}} \\
\text { Common/dm } \\
\text { Many/dm } \\
<1 \mathrm{~mm} \mathrm{dia} \\
1 \text { to } 2 \mathrm{~mm} \text { diameter } \\
2 \text { to } 5 \mathrm{~mm} \text { diameter } \\
>5 \mathrm{~mm} \text { diameter }\end{array}$ \\
\hline Pores & $\begin{array}{l}1 \\
2 \\
3 \\
\text { vf } \\
\mathrm{f} \\
\mathrm{m} \\
\text { tub } \\
\text { ves } \\
\text { ir }\end{array}$ & $\begin{array}{l}\text { Few present } \\
\text { Commonly present } \\
\text { Many present } \\
\text { Very fine } \\
\text { Fine } \\
\text { Medium } \\
\text { Tubular shape } \\
\text { Vesicular shpe } \\
\text { Irregular shape }\end{array}$ & $\begin{array}{l}\text { Few/dm }{ }^{\mathrm{a}} \\
\text { Common/dm }{ }^{\mathrm{a}} \\
\text { Many/dm } \\
0.1 \text { to } 0.5 \mathrm{~mm} \text { diameter } \\
0.5 \text { to } 2 \mathrm{~mm} \text { diameter } \\
2 \text { to } 5 \mathrm{~mm} \text { diameter } \\
\text { Cylindrical, elongate pores } \\
\text { Spherical or elliptical pores } \\
\text { Walls of pores curves or angular }\end{array}$ \\
\hline Lower boundary & $\begin{array}{l}\text { a } \\
\text { c } \\
\text { g } \\
\text { d } \\
\text { i } \\
\text { s } \\
\text { w } \\
\text { b }\end{array}$ & $\begin{array}{l}\text { Abrupt } \\
\text { Clear } \\
\text { Gradual } \\
\text { diffuse } \\
\text { Irregular } \\
\text { Smooth } \\
\text { Wavy } \\
\text { Broken }\end{array}$ & $\begin{array}{l}\text { Transition w/in } 1 \mathrm{~mm} \text { to } 2.5 \mathrm{~cm} \\
\text { Transition w/in } 2.5 \text { to } 6 \mathrm{~cm} \\
\text { Transition w/in } 6 \text { to } 12.5 \mathrm{~cm} \\
\text { Transition }>12.5 \mathrm{~cm} \\
\text { Undulates, pocket depths > widths } \\
\text { Parallel to ground surface } \\
\text { Undulates, pocket depths < widths } \\
\text { Parts of horizon laterally discontinuous }\end{array}$ \\
\hline
\end{tabular}


MP 45.1, Seward Highway. Summit Lake, at $400 \mathrm{~m}(\sim 1,320 \mathrm{ft})$ elevation, is $1.9 \mathrm{~km}$ (1.2 mi) long. The prominent bench $24 \mathrm{~m}(\sim 80 \mathrm{ft})$ above the shore across the lake developed late in the Naptowne glaciation when colluvium from the slopes above accumulated against stagnant glacial ice that then occupied the floor of the valley. Subsequent melting of this ice mass left the bench scarps on either side of the lake and the basin now occupied by Summit Lake. Evidence of frequent snow avalanching is widespread in this area. In the ridges west of the highway are several lode gold mines, some still active, along north-northeast-trending shear zones in the Valdez Group (Martin and others, 1915).

MP 39.5, Seward Highway. Upper crossing of Quartz Creek. We will cross this stream again on the Sterling Highway west of our next stop.

Â 38.6, Seward Highway. Jerome Lake occupies a narrow, glacier-scoured bedrock trough. Drive past the initial Soldotna/Sterling Highway turnoff, continuing toward Seward. At MP 37 of the Seward Highway turn right onto the Sterling Highway.
MP 37, Sterling Highway. ${ }^{7}$ Turn left (south) into the parking area next to Tern Lake.

\section{STOP 2. TERN LAKE}

This locality is situated in a classically $\mathbf{U}$-shaped glacial valley in the northcentral Kenai Mountains. Along its western side, Tern Lake, at 182 m ( 600 ft) elevation, is ponded against a bedrock ridge at the distal end of an outwash train that originates at a late Elmendorf end moraine $4 \mathrm{~km}(\sim 2.5 \mathrm{mi})$ to the southeast near Upper Trail Lake (Lemke, 1994). Between 240 and $700 \mathrm{~m}$ ( 800 and $2,300 \mathrm{ft}$ ) above us on the valley wall to the south is a large bedrock failure (fig. 14). This massive failure in foliated argillites and graywacke metasandstones of the Valdez Group (Nelson and others, 1985) is slowly creeping toward us. We identify landslides of this type by several features, including trenches along ridge crests (split ridges) and upper slopes, open tension cracks transverse to the slope and scarps that face uphill in the

${ }_{7}$ Mileposts along Sterling Highway are referenced from Seward, MP 0.

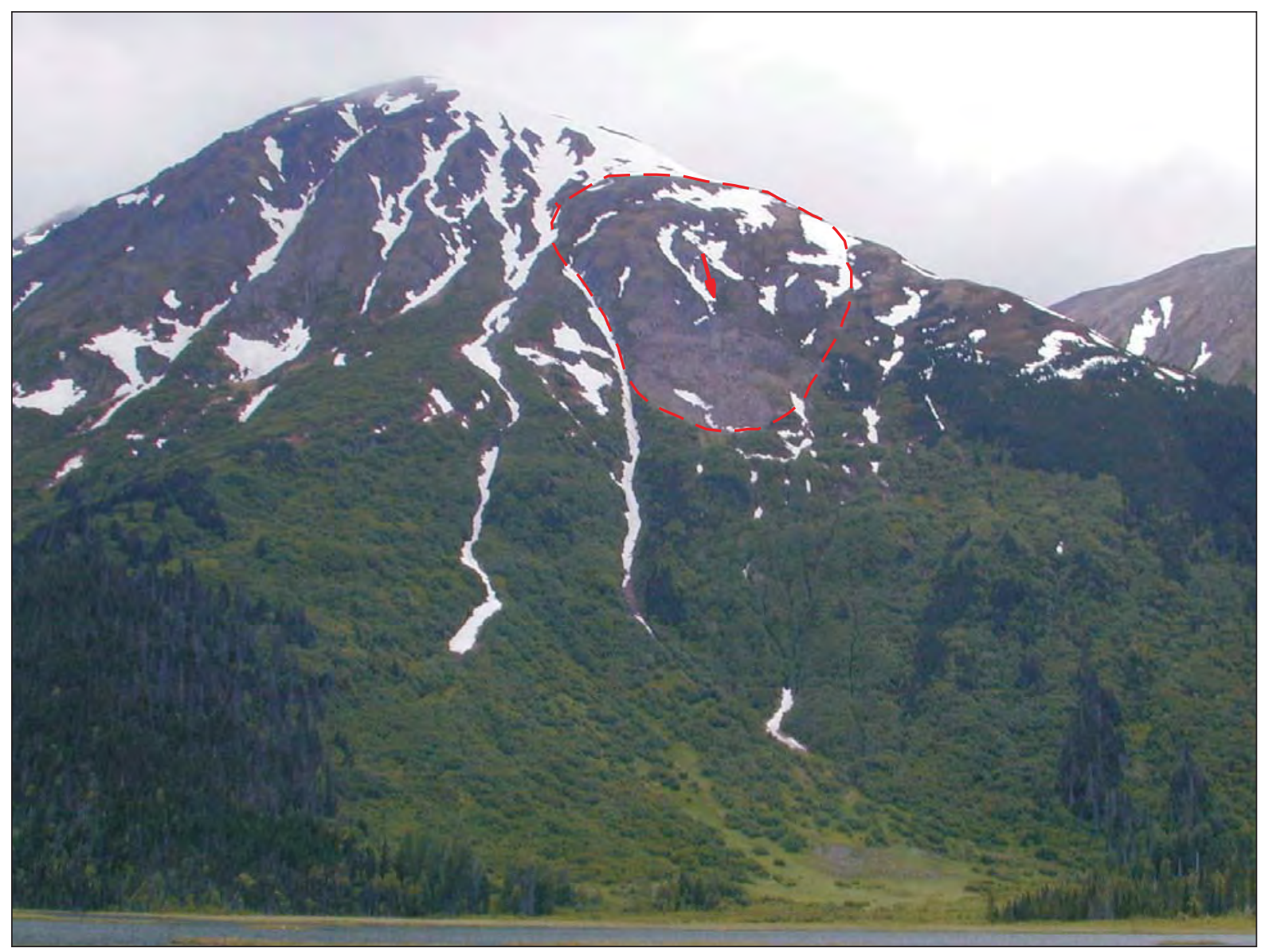

Figure 14. Massive failure in bedrock above Tern Lake near Stop 2. Arrow indicates direction of dominant downslope movement. 
bodies of the failures, by bulging toes, and by fresh rock debris downslope from the toes of the failures (fig. 15). Bedrock failures are typically associated with alpine glaciated terrain, where a significant amount of bedrock erosion increases topographic relief. In $\mathbf{U}$-shaped valleys such as this one, bedrock joints develop subparallel to oversteepened valley walls in response to dilation relief of isostatic depression. These joints are zones of bedrock weakness, particularly in fine-grained rocks with low shear strengths. Downslope creep of bedrock then progressively destabilizes the valley walls, leading eventually to sudden slope failure as a massive rock avalanche.

The Tern Lake area is important as the site of the first radiocarbon-calibrated record of postglacial veg- etation in the northern Kenai Mountains (Ager, 2001). This locality is transitional between coastal rain forest to the east and south and boreal forest in the western and northern Kenai Mountains. The evolution of this transition is preserved in a 103-cm (40-in) section of fibrous peat that was collected in a roadcut nearby by Tom Ager and analyzed for pollen and spores (Ager, 2001). He analyzed 21 samples through the section and developed profiles of arboreal and nonarboreal pollen and spores, which he calibrated with five radiocarbon dates (fig. 16).

The profile is divisible into four zones. The lowest zone (T-4) represents a treeless herb-shrub flora that began colonizing the barren outwash gravel and freshly exposed glacial till $\sim 9.8$ RC kya ( 11.3 cal kya).

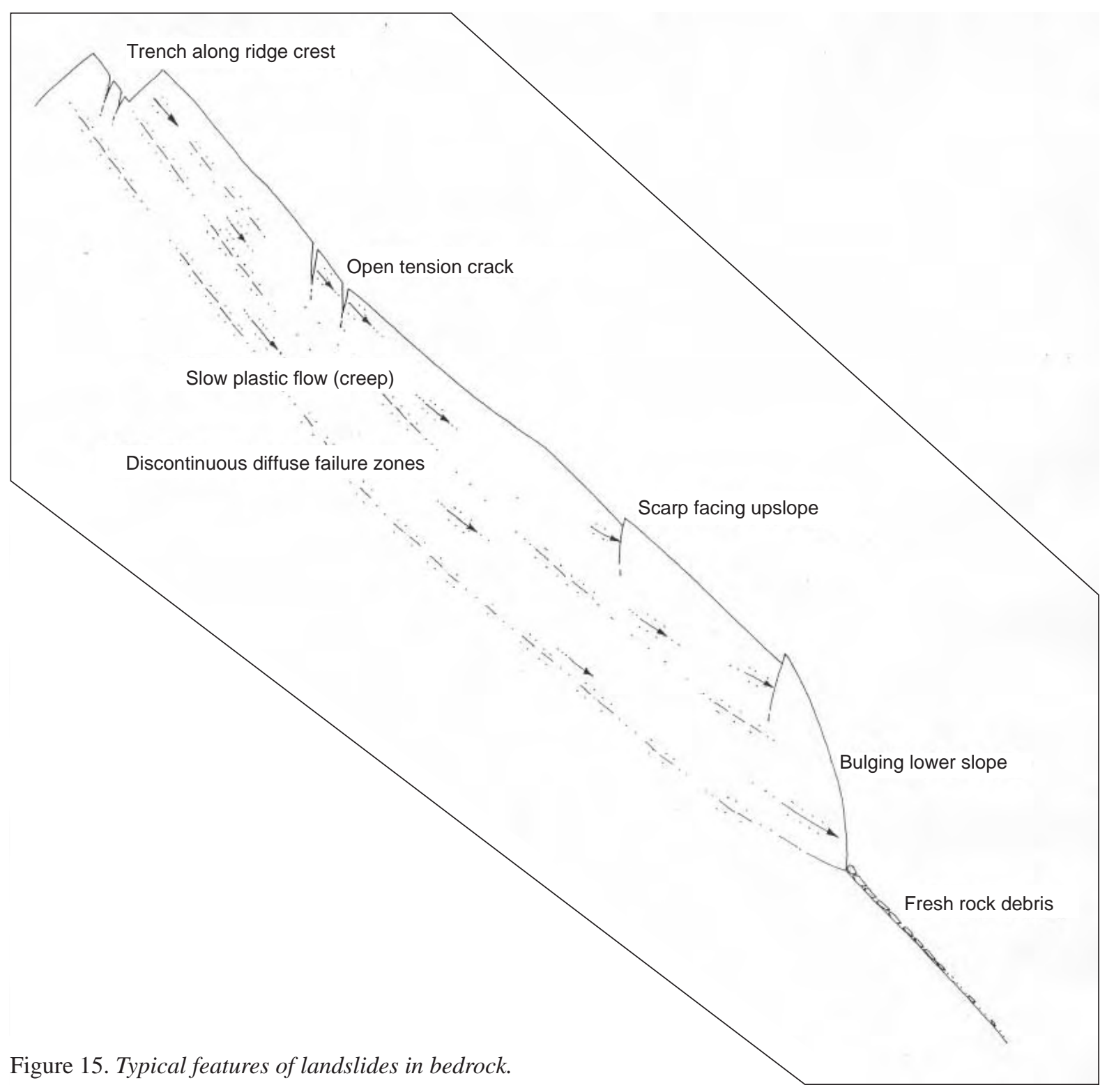




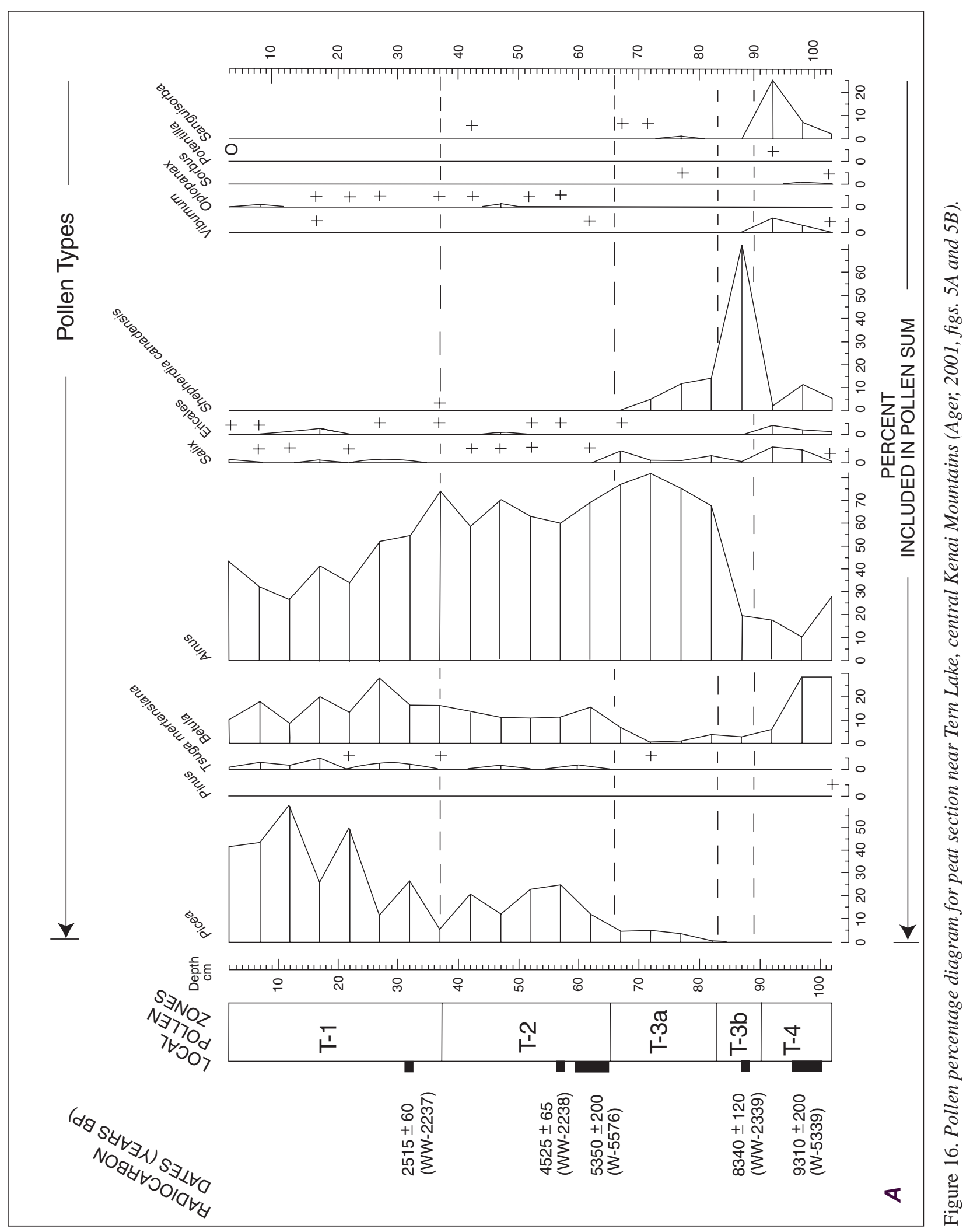




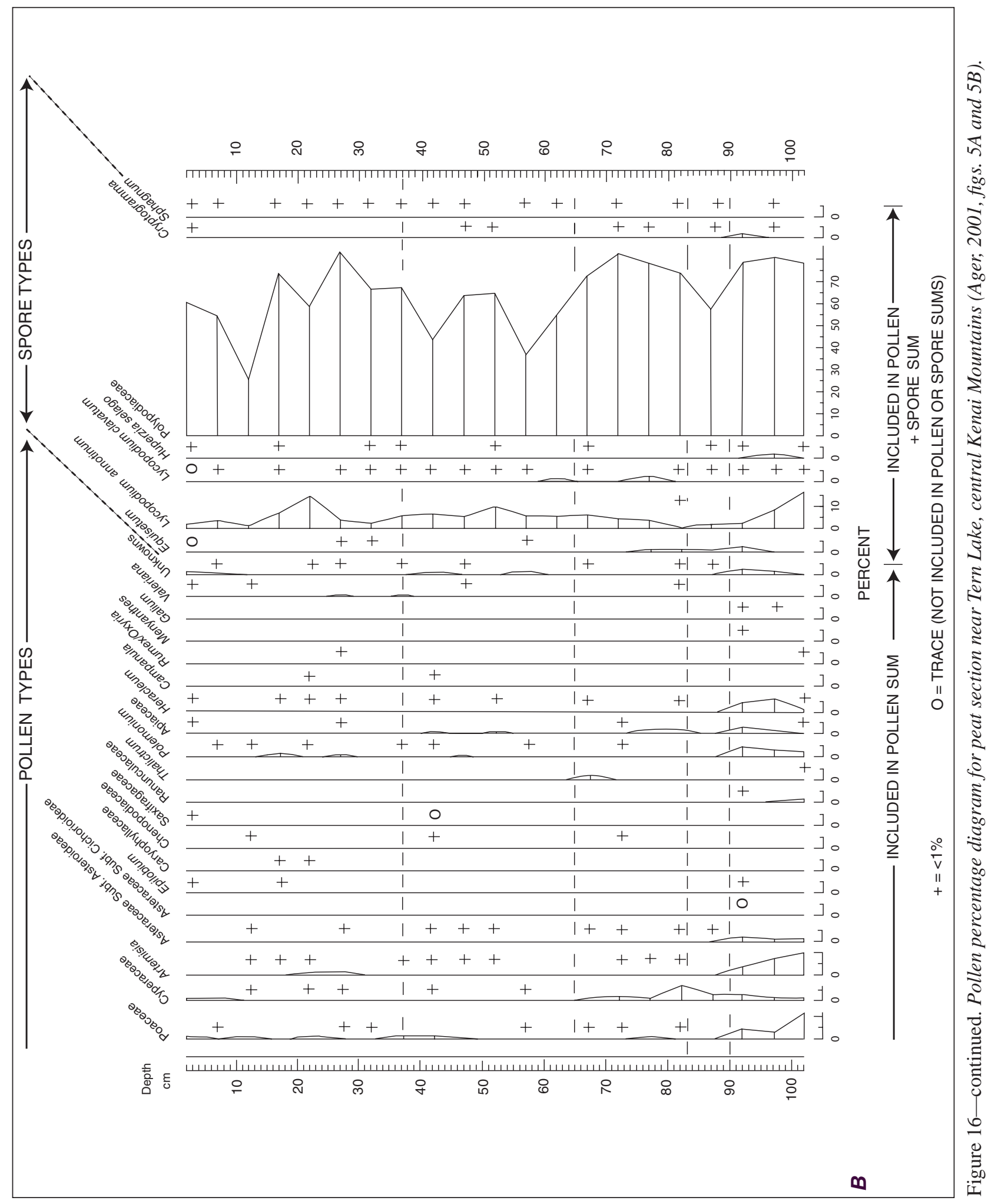


Pioneering plants included shrub birch (dominant pollen) with lesser alder, willow, soapberry, highbush cranberry, mountain ash, and several low, woody plants and herbs. These plants probably formed herb meadows with scattered shrub thickets. The presence of abundant fern spores indicates that moist habitats were common. A sharp spike of soapberry pollen and abundant fern spores in a single $8.3 \mathrm{RC}$ ka $(9.3 \mathrm{cal} \mathrm{ka})$ sample in Zone T-3b is interpreted to indicate some sort of local environmental disturbance, perhaps a flood or a resurgence of gravel aggradation that could signal a minor Holocene glacial advance that may have destroyed the established floodplain vegetation. Soapberry, alders, and ferns would then have aggressively colonized the barren floodplain surfaces. However, there is no other local evidence to substantiate this interpretation. Shortly after 7.8 RC kya (8.7 cal kya), alders aggressively colonized this valley, overwhelming birch, soapberry, and willow shrubs and most herbaceous plants. Minor spruce pollen, probably wind borne from distant sites in northern Kenai Peninsula lowland, began arriving early in T-3a time. We will examine the evidence for rapid dispersal of boreal spruce there about this time at later stops. Between $\sim 5.4$ and 3.0 RC kya ( 6.1 and $3.2 \mathrm{cal}$ kya) (Zone T-2), trees of boreal affinity (like white and black spruce and birch) invaded the Tern Lake area and partially replaced formerly widespread alder thickets. Pollen of mountain hemlock began arriving, probably from distant sources in Prince William Sound, early in this interval, but hemlock trees came later. Clearly, by mid-Holocene time boreal and non-arboreal coast floral elements were mixing in this interior mountain valley. During the past $\sim 2.9$ RC ka ( 3.0 cal ka) (Zone T-1), alder thickets were progressively replaced first by boreal forest elements and, after $\sim 2.0$ RC kya ( $\sim 2.0 \mathrm{cal}$ kya), by both boreal and coastal forest elements to form the transitional forest we see in this area today.

From Tern Lake we turn west and drive along the Sterling Highway, following the path taken by thick, coalescing glacial streams flowing out of the valleys of Summit Lake and Tern Lake toward the Kenai Lake trough during the height of the Naptowne glaciation.

MP 38, Sterling Highway. Note the talus apron formed along the base of the steep bedrock slope to the north by downslope movement of fragments of frost-split slates and metasandstones of the Valdez Group following retreat of late Elmendorf ice in this valley. These angular rock fragments were crushed for inferior-grade fill during early construction of the Sterling Highway and produced many flat tires.

CA 40.7, Sterling Highway. View toward west of upper entrance to Shaft Creek valley, a classic-appearing hanging valley (fig. 17), except that instead of being a tributary to the trunk glacier in Quartz Creek valley, ice split from the trunk glacier in Quartz Creek valley and flowed west-northwest toward Juneau Creek valley. Mapping in the Seward C-8 Quadrangle (fig. 18) established the limits of the Naptowne glaciation, located ice caps that supplied local ice to the Cordilleran ice sheet to the east, and fixed the limits of periglacial uplands along the western margin of the northwestern Kenai Mountains that provided a refugium during the Naptowne glaciation and contain evidence of two pre-Naptowne glaciations. This mapping indicates that glacial ice at the climax of the Naptowne glaciation was 1,120 m ( 3,700 ft) thick in the lower valley of Quartz Creek.

A MP 40.9, Sterling Highway. Lower crossing of Quartz Creek. For the next $3.2 \mathrm{~km}(\sim 2 \mathrm{mi})$ water-saturated lake sediments formerly produced very unstable slopes along the west side of the Sterling Highway and destabilized the roadbed. Subsequent loading of the slopes with riprap and armor rock on top of geotextiles, cutting of deep, wide ditches along the toe of the slope, and installation of french drains allowed the soil moisture to drain away, producing a much improved road through this area. The fine-grained lake sediments accumulated in lower Quartz Creek valley, which was dammed in late Elmendorf time by ice in the Kenai Lake trough ahead (Lemke, 1994).

Photo interpretation in this area allowed reconstruction of the highest ice levels during the last major glaciation from lower Quartz Creek westward through the upper Kenai River valley to the Jean Lakes area (fig. 19). The profile (fig. 20) indicates that the Moosehorn-age trunk glacier sloped westward $\sim 20 \mathrm{~m} / \mathrm{km}$ ( $\sim 106 \mathrm{ft} / \mathrm{mi}$ ) (2 percent) between Langille Mountain and Hideout Hill.

MP 44.9, Sterling Highway. View west across Kenai Lake of Round Mountain, which at 1,189 m (3,894 ft) elevation, stood as a nunatak above the highest ice of the last major glaciation $(\sim 1,000 \mathrm{~m}[\sim 3,300$ $\mathrm{ft}$ ] elevation) (fig. 21). To the right, Slaughter Gulch is the entrance to another hanging valley through which Naptowne ice of the Kenai Lake lobe diverged northwestward toward Juneau Lake valley. Kenai Lake, at $132 \mathrm{~m}$ (436 ft) elevation, is $38 \mathrm{~km}$ (24 mi) long and has a surface area of $55.9 \mathrm{~km}^{2}\left(21.6 \mathrm{mi}^{2}\right)$. This large lake occupies a narrow, angular trough scoured by thick glacial ice along linear zones of structural weakness in the Valdez Group. The lake has a fairly flat bottom with an average depth of $\sim 91 \mathrm{~m}$ (300 ft) and a maximum depth of $\sim 165 \mathrm{~m}$ ( $\sim 545 \mathrm{ft})$. Kenai Lake seiched spectacularly during the great Alaska earthquake of March 27, 1964, flooding nearshore structures (McCulloch, 1966). Simultaneous earthquake shaking caused local liquefaction and produced numerous sublacustrine slides. 
Kenai River begins at the west end of Kenai Lake and is well known for its turquoise color, which is due to dispersed clay-sized particles brought into the lake by meltwaters from glaciers in the drainage basin. Every 2 to 4 yrs, a glacier-impounded lake $32 \mathrm{~km}$ ( 20 mi) east of Kenai Lake suddenly drains down one of these meltwater tributaries, Snow River, and indirectly produces an outburst flood down the Kenai River (Post and Mayo, 1971).

MP 47.9, Sterling Highway. Crossing of headwaters of upper Kenai River at the west end of Kenai Lake. During the 1964 A.D. Alaska earthquake the highway bridge at this site was literally thrown upstream into the lake, disrupting traffic until a temporary crossing could be emplaced (Johnson, 2005, p. 15). Ahead on the hillside are wet, clay-rich morainal deposits with incorporated lake sediments.

MP 48.1, Sterling Highway. Cooper Landing. For the next $3.2 \mathrm{~km}$ (2 mi) Sterling Highway follows the entrenched valley of upper Kenai River through sandy ice-stagnation gravels to Cooper Creek. In the Cooper Landing area, these late Elmendorf ice-stagnation gravels reach a modern elevation of $290 \mathrm{~m}$ ( 950 ft).

MP 49.4, Sterling Highway. To the north, upper Kenai River passes down a narrow chute through the cobble-boulder lag that armors the riverbed throughout the length of the stream (fig. 22).

MP 50.3, Sterling Highway. Juneau Creek enters the north side of the upper Kenai River, and Cooper Creek enters from the south at MP 50.5. The high section to the left (south) exposes ice-stagnation sands and gravels overlying lake sediments of unknown extent, the source of mudflows that apron the lower slope. The presence of sandy gravels over the lakebeds is evidence that late in the Elmendorf stade, perhaps during the Younger Dryas cold period, the glacier in the upper Kenai River valley thickened and readvanced westward across a former lake basin. During this readvance, ice spread

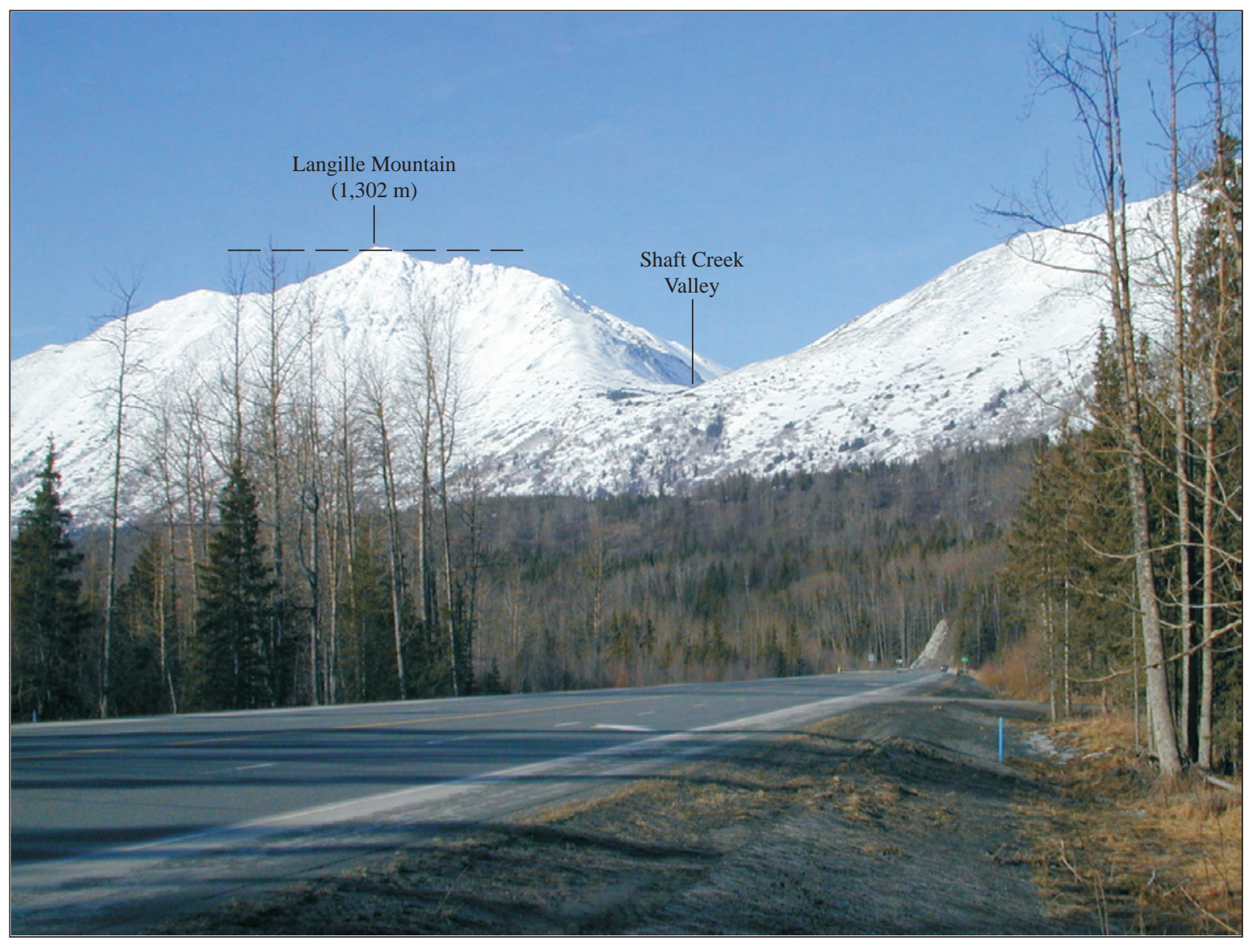

Figure 17. View west from MP 40.7, Sterling Highway, of Langille Mountain (1,302 m [4,297 ft]) and Shaft Creek valley, a classic hanging glacial valley. Dashed line shows level of glacial ice ( 1,290 m [4,257 ft]) during Moosehorn stade of Naptowne glaciation (photograph taken 03-17-05). 


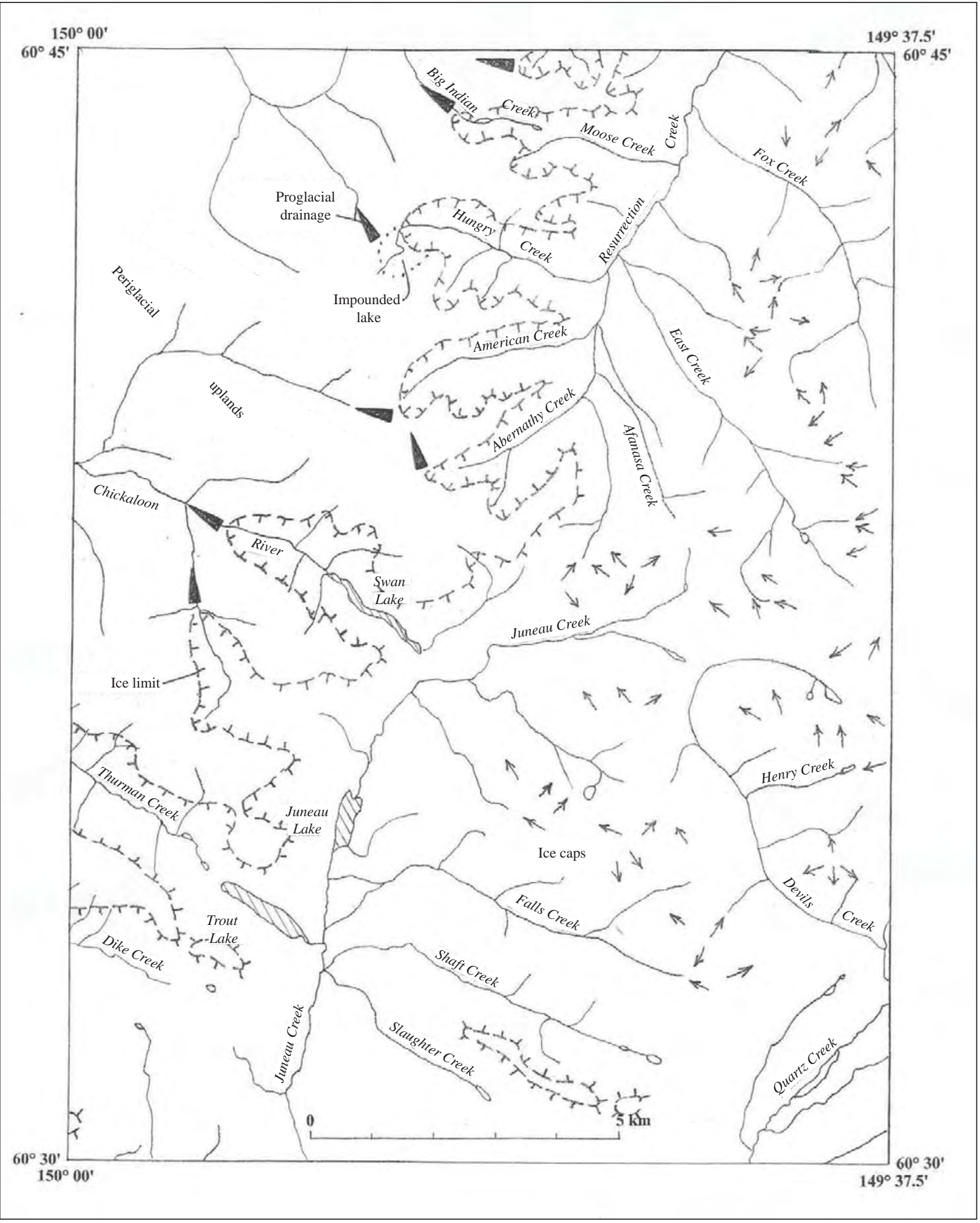

Figure 18. Paleogeography of Seward C-8 Quadrangle, northwestern Kenai Mountains, at climax of Naptowne glaciation (Moosehorn stade). Short arrows indicate directions of ice flow from local accumulation centers. Heavy arrowheads indicate sources of proglacial drainages. Location shown in figure 24. 


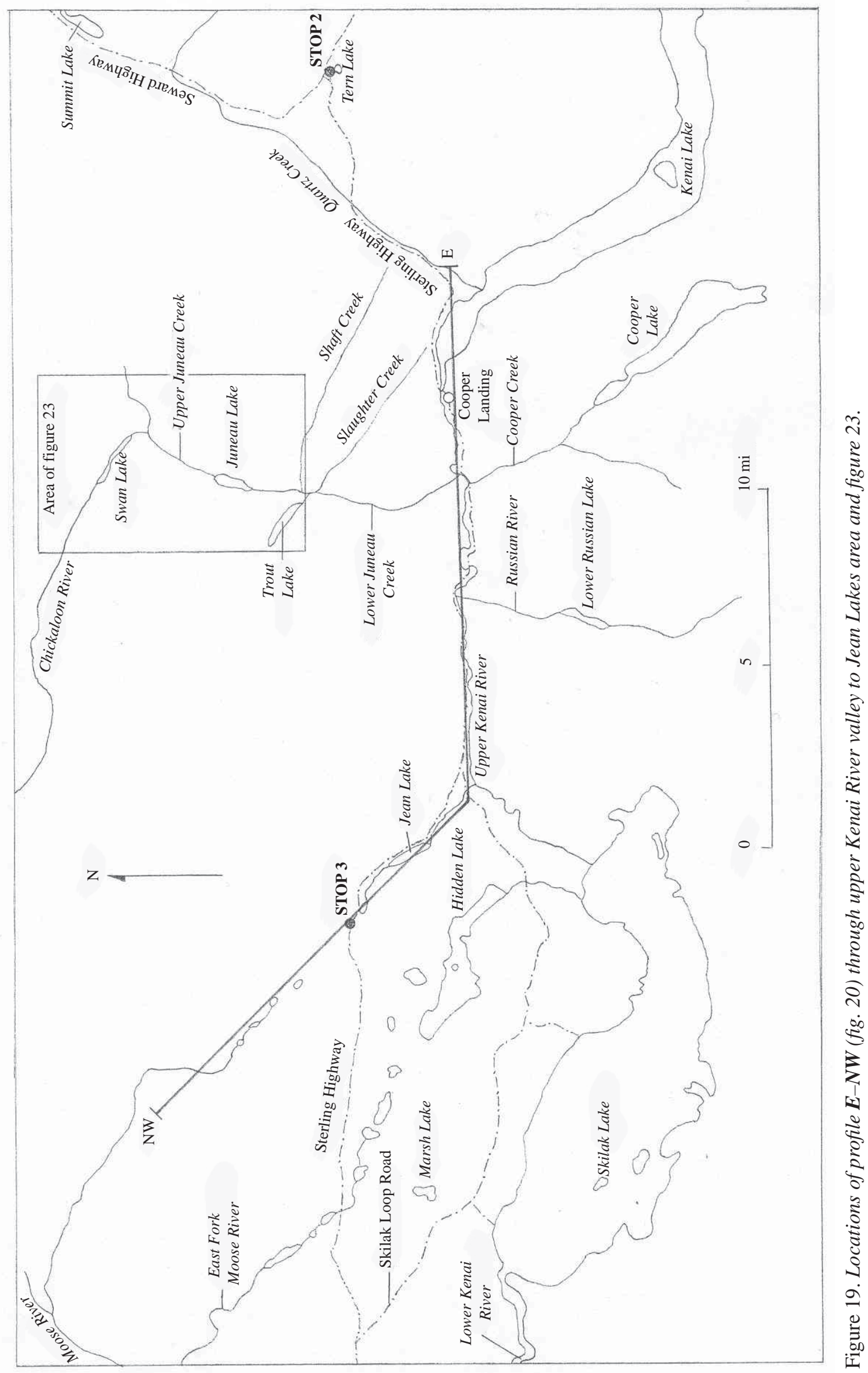




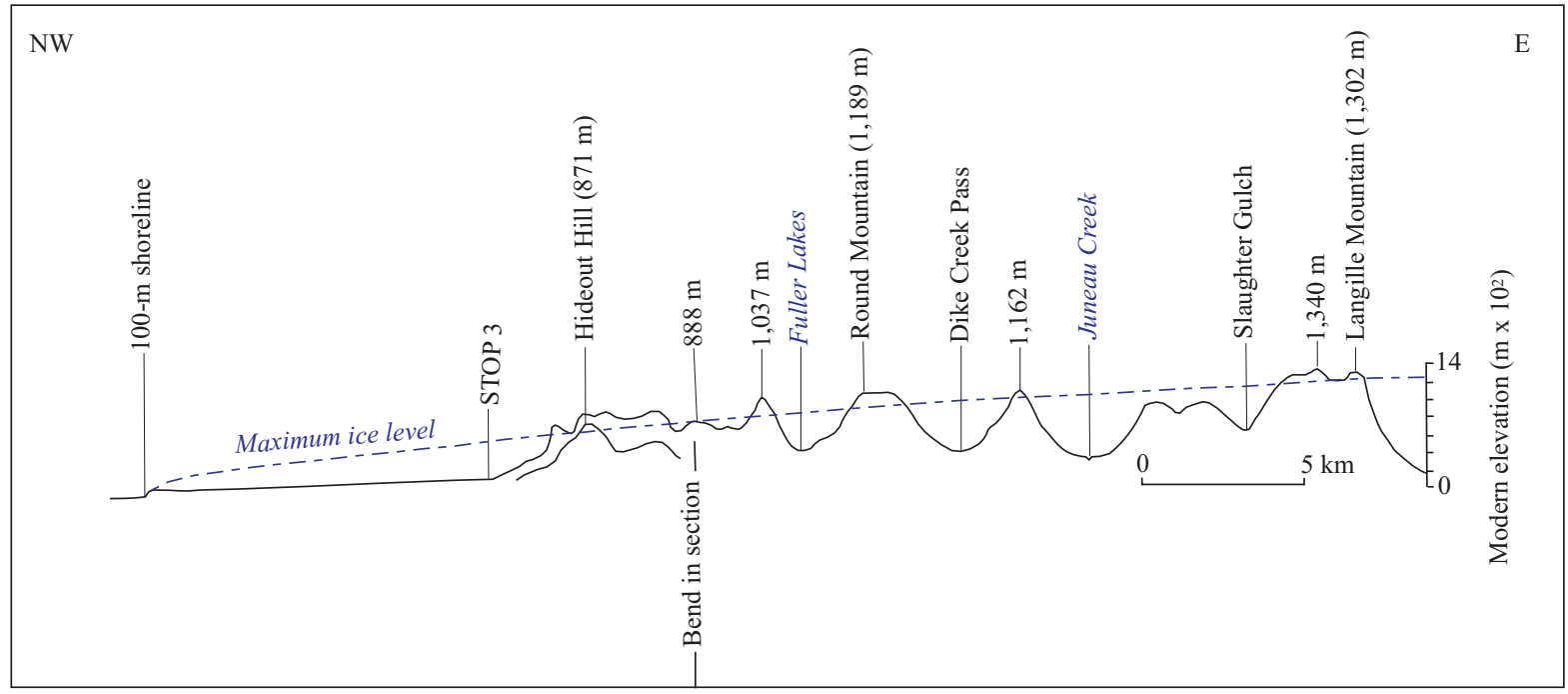

Figure 20. Profile $\boldsymbol{E}-\mathbf{N W}$ of highest ice level during Moosehorn stade of Naptowne glaciation from lower Quartz Creek to Jean Lakes area. See figure 19 for profile location.

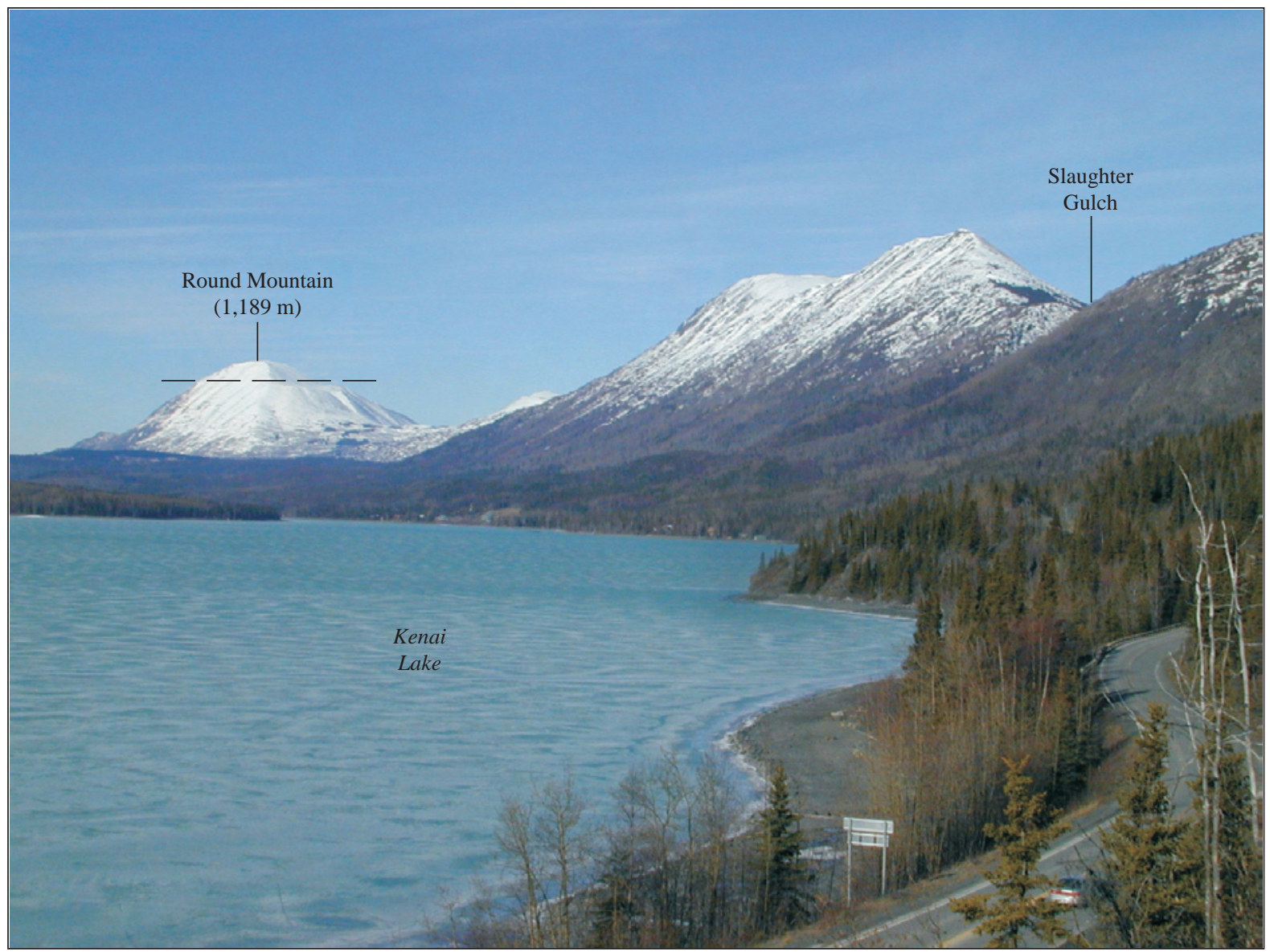

Figure 21. View west from outcrop above MP 44.9, Sterling Highway, of Round Mountain (1,189 m [3,924 ft]). Dashed line shows level of glacial ice ( 1,000 m [3,300 ft]) during Moosehorn stade of Naptowne glaciation, and Slaughter Gulch at end of a hanging glacial valley (photograph taken 03-17-05). 


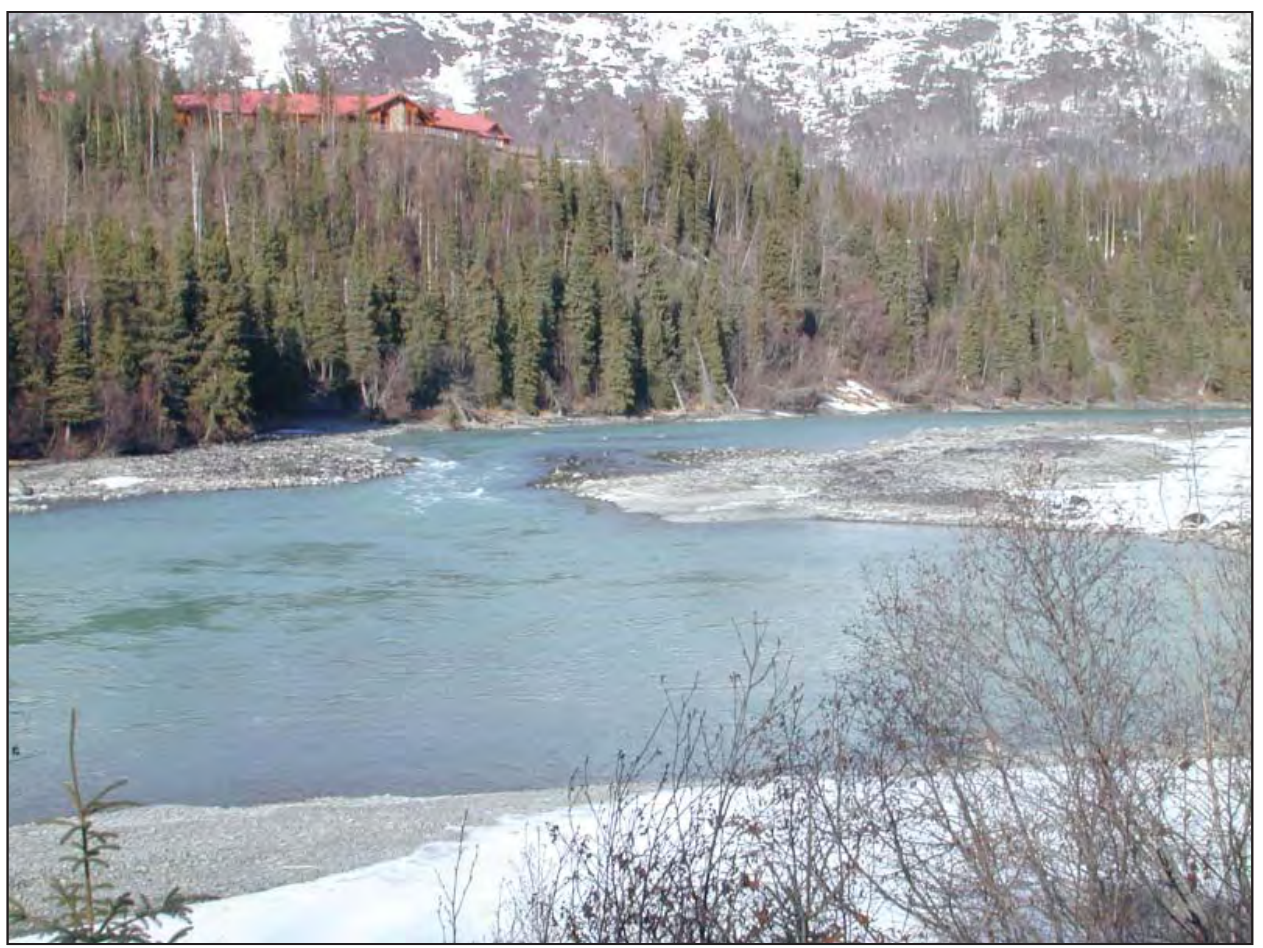

Figure 22. View north from MP 49.4, Sterling Highway, of narrow chute of Kenai River through cobble-boulder lag that armors river bed (photograph taken 03-11-05).

northward up the valley of Juneau Creek, where it split into two lobes (fig. 23). One lobe was diverted northwestward up the valley now occupied by Trout Lake and the other lobe continued northward up the Juneau Creek valley. The northern lobe advanced to a position $11 \mathrm{~km}$ ( $\sim 7 \mathrm{mi})$ north of the upper Kenai River valley, just north of Juneau Lake, and impounded a narrow meltwater lake. The presence of a discontinuous shoreline indicates that the former lake rose to $455 \mathrm{~m}$ ( $1,500 \mathrm{ft}$ ) elevation before spilling through the pass at the northwest end of Swan Lake and draining down Chickaloon River. The present elevation of Swan Lake (422 m [1,391 ft]) indicates that $33 \mathrm{~m}(\sim 110 \mathrm{ft})$ of downcutting subsequently occurred in the pass. In the vicinity of Juneau Lake, the moraine that impounded the meltwater lake has an elevation of $500 \mathrm{~m}(\sim 1,650 \mathrm{ft})$. For the glacier to flow northward, the ice level in the upper Kenai River valley must have been higher than $500 \mathrm{~m}(1,650 \mathrm{ft})$, perhaps as high as a modern elevation of $670 \mathrm{~m}(\sim 2,200 \mathrm{ft})$, an ice-surface gradient of $15 \mathrm{~m} / \mathrm{km}(\sim 80 \mathrm{ft} / \mathrm{mi})$ and well above the highest ice-stagnation deposits at Cooper Landing. When the readvance ended, the glaciers stagnated, thinned, and withdrew from terminal moraines in Juneau Creek valley. In the process, the terminal moraine just north of Juneau Lake was breached, the formerly impounded lake drained, and basins now occupied by Juneau Lake and Trout Lake were exposed. Today, upper Juneau Creek winds tortuously across the poorly drained floor of the former lake basin at an elevation of $390 \mathrm{~m}$ ( 1,300 ft) before passing through the breach in the former terminal moraine and entering Juneau Lake at $373 \mathrm{~m}(1,231 \mathrm{ft})$ elevation.

The earliest placer-gold claims in this area were staked on Cooper Creek and its tributary, Stetson Creek, by C.H. Sickles in 1896 (Barry, 1997). The alluvial fan of lower Cooper Creek was thoroughly reworked by hydraulicking from 1908 through 1911 A.D. (Martin and others, 1915; Barry, 1997). As of 1982 A.D., an estimated 43,500 g (1,400 ozs) of placer gold had been mined from the Cooper-Stetson Creek drainage (Hoekzema, 1985). Attempts to dredge upper Kenai River between the mouths of Cooper Creek and the Russian River with locally assembled wood dredges in 1911-1912 A.D. were thwarted by the large cobbles and boulders that armor the river bed (Buzzell, 1985).

From September through March each year, silver salmon make life-ending journeys to spawn in upper Kenai River and its tributaries. Their flesh and eggs are sought by people, brown bears, and a variety of predacious birds and fishes. For $\sim 3$ millennia, people of Riverine Kachemak (Pacific Eskimo) and Denaina Athapaskan (Indian) cultures left house pits and fishstorage pits along terraces of the upper Kenai River as traces of their former presence (D.R. Reger, 2004). In the reach between Cooper Creek and the Russian River, these prehistoric remains are interspersed with scattered historic prospecting pits. 


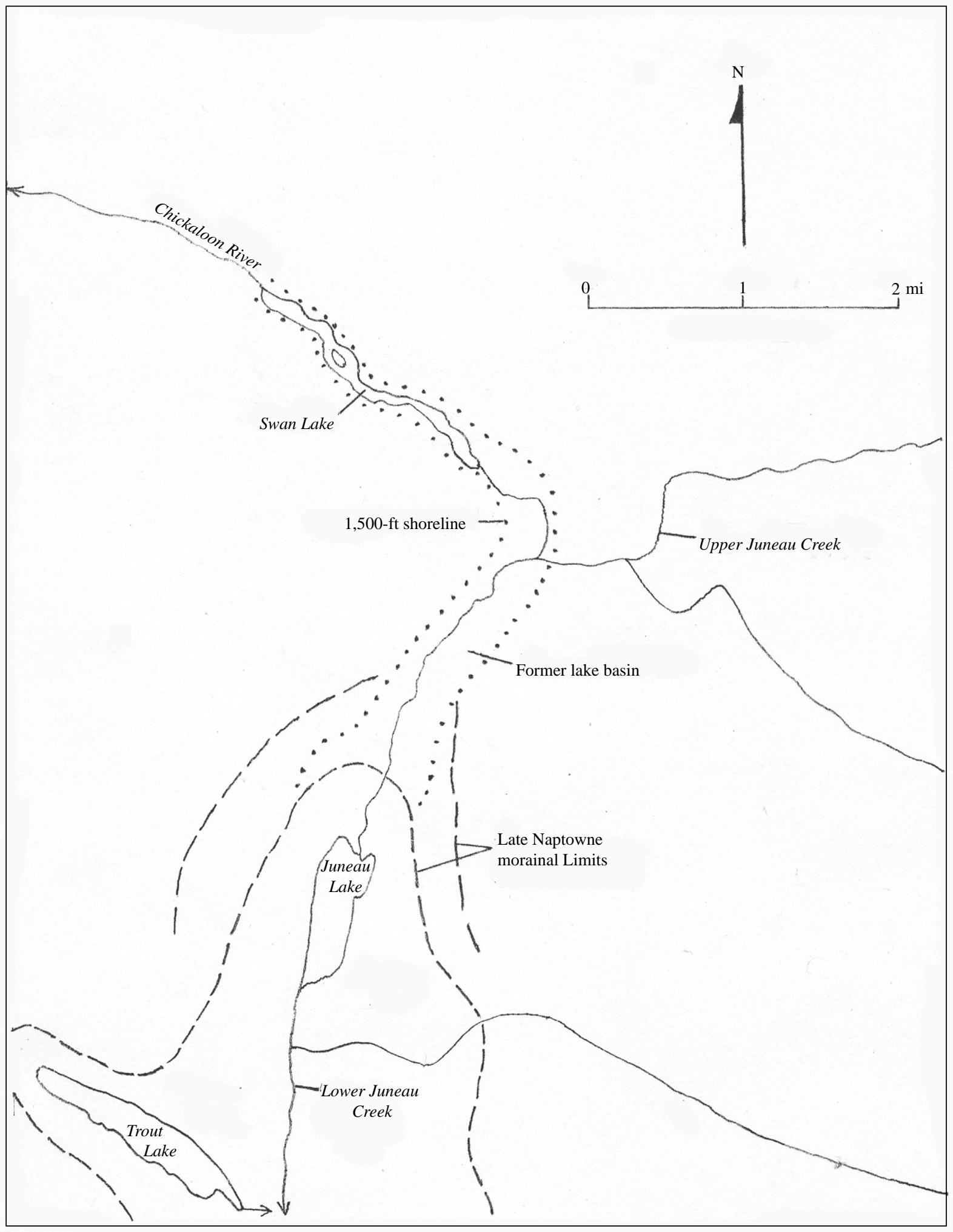

Figure 23. Paleogeography of Juneau Lake-Swan Lake area during Elmendorf stade of Naptowne glaciation, based on interpretation of 1:63,360-scale false-color infrared aerial photo 205 taken August 1984. 
MP 52.5, Sterling Highway. Entrance to Russian River campground, operated in Chugach National Forest by the U.S. Forest Service.

MP 53, Sterling Highway. Crossing of the upper Kenai River. Till of Elmendorf age is exposed in the high west bank above the highway bridge. An outwash terrace extends westward at least $2.6 \mathrm{~km}(1.6 \mathrm{mi})$ from this location.

AP 54.9, Sterling Highway. Mouth of the Russian River. Because abundant red salmon dependably return each summer to spawn in Lower Russian Lake and are readily available for exploitation, the confluence of the Russian River and upper Kenai River has long been a focus, at least seasonally, of salmon predators, like brown bears, bald eagles, and humans. The oldest artifacts in this area demonstrate that people have traversed the upper Kenai River corridor for at least 8 to 10 RC ka (9.0 to 11.4 cal ka) (Reger, 1985). A variety of hunting and fish-processing artifacts, house structures, and evidence of contrasting mortuary practices, like flexed burials vs cremations, indicates that people have been attracted to this area from as far away as Prince William Sound and Cook Inlet. An incomplete inventory documents occupations by people who left cores and microblades ( 8.0 to 10.0 RC kya) ( 9.0 to $11.4 \mathrm{cal} \mathrm{kya)}$ and side-notched projectile points ( $\sim .5$ to $4.0 \mathrm{RC}$ kya) ( 5.1 to $4.4 \mathrm{cal}$ kya), by Riverine Kachemak Eskimos ( 3.0 to 1.0 RC kya) ( 3.2 to 0.9 cal kya), and by Denaina Athapaskan-speaking Kenaitzi Indians ( 1.0 RC kya to historic) ( $\sim .9$ cal kya to modern) from the Kenai area (D.R. Reger, 2004).

As we drive west we enter sheet 1 of a series of six sheets that show key paleogeographic and geographic features near the rest of the field trip route (fig. 24). We recommend that you refer to these sheets as we proceed. The map bases are metric and provide elevations in meters; we have provided U.S. units as well. We will continue to use road miles for reference along the various highway routes.

MP 57.2, Sterling Highway. Trailhead for Fuller Lakes trail. During the Naptowne glaciation, ice from the valley of the upper Kenai River expanded northward between Mystery Hills and Round Mountain into the headwaters of Mystery Creek and built nested end moraines of Moosehorn age that enclose Fuller Lake at $507 \mathrm{~m}$ (1,663 ft) elevation (sheet 1). Outwash from this lobe extends northwestward down the Mystery Creek drainage. A tree-ring chronology back to 1525 A.D. from treeline mountain hemlock in the Skyline-Fuller Lakes trail area indicates that the coolest part of the later Little Ice Age was in the 1810s A.D. (De Volder, 1999). A 19th-century cooling is confirmed at nearby
Goat Lake by measurement of growth rings in mountain hemlock (Daigle, 2006) and by simultaneous suppression of pollen production of local treeline trees (Scott Anderson and others, unpublished data).

Evidence of contemporary climate warming is present in this area, where mountain hemlock typically grows in a dark green band above white spruce treeline. In exposed sites, old, gnarled hemlock krumholz forms grow close to the ground surface, but young hemlock saplings grow upright as normal trees at the same sites. This change in growth form of different-aged trees indicates that the mountain climate has recently ameliorated (Berg, 2004). Corroborating evidence is found on cool north-facing slopes where white spruce seedlings grow many meters above the hemlock zone because the white spruce vegetation zone has simply leapfrogged over the hemlock zone.

Dial and others (in press) classified alpine vegetation in the Mystery Hills at 978 points on georeferenced aerial photographs from 1951 A.D. and 1996 A.D. and found that shrubline rose $\sim 13 \mathrm{~m}(\sim 43 \mathrm{ft})$ per decade, while treeline rose $\sim 11 \mathrm{~m}(\sim 36 \mathrm{ft})$ per decade and closedcanopy forest rose $<1 \mathrm{~m}(<3.3 \mathrm{ft})$ per decade. The rise of treeline accompanied a near doubling in the area of closed-canopy forest above $450 \mathrm{~m}$ (1,476 ft) elevation (fig. 25). Three alpine sites were classified on a 15-m $(\sim 50-\mathrm{ft})$ grid spacing and showed that treeline advance in the western Kenai Mountains is basically an infilling process, like spots of mold spreading on a piece of bread rather than like the rise of water level in a bathtub (Newbould, 2007) (fig. 26).

AP 58, Sterling Highway. Junction of Sterling Highway and east end of Skilak Loop Road. Vegetated roadcuts along Sterling Highway for the next $1.3 \mathrm{~km}$ (0.8 $\mathrm{mi}$ ) formerly exposed tan sandy silt of Elmendorf age that accumulated in a small lake that formerly occupied the valley of Jean Creek. This lake was impounded at $\sim 100 \mathrm{~m}(\sim 320 \mathrm{ft})$ elevation between the northwestern edge of the glacier that terminated $4 \mathrm{~km}(\sim 2.5 \mathrm{mi})$ southwest of this location and the Skilak-age end moraine of the Jean Lake lobe at MP 59.1 (fig. 11, sheet 1).

AP 58.6, Sterling Highway. View northwest of Hideout Hill (871 m [2,858 ft]), a former nunatak composed of McHugh Complex of Mesozoic age (Karl and others, 1997b, sheet 1), which was overridden by ice during a pre-Naptowne glaciation and nearly overridden during the Moosehorn stade of the Naptowne glaciation (fig. 27). A prominent late Moosehorn ice limit is delineated by lateral moraines at $\sim 530 \mathrm{~m}(\sim 1,740 \mathrm{ft})$ elevation on the east flank of Hideout Hill and on the opposite wall of the Jean Lake trough and by a deep notch cut in bedrock by an ice-marginal stream across a ridge crest (sheet 1$)$. 


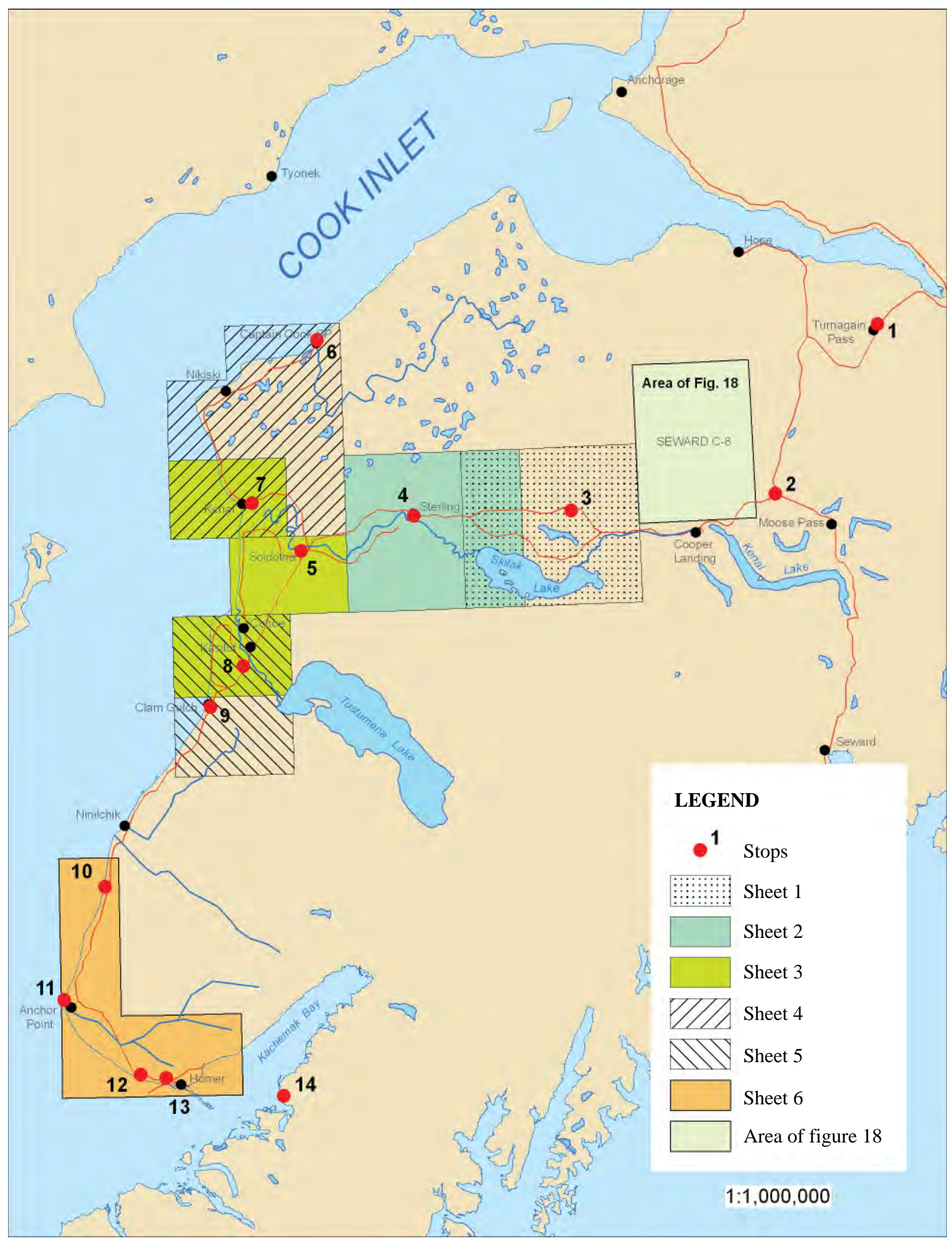

Figure 24. Index map of sheets 1-6 and location of figure 18. 
定 MP 59.1, Sterling Highway. Jean Lake (118 m [387 ft] elevation) is $\sim 1.4 \mathrm{~km}(\sim 0.9 \mathrm{mi})$ long and is nestled in a bedrock trough that was scoured during the Naptowne glaciation by ice that flowed northwestward as the Jean Lake lobe from the trunk glacier in upper Kenai River valley. In the Jean Lake trough the glacier was $\sim 700 \mathrm{~m}(\sim 2,300 \mathrm{ft})$ thick during the Moosehorn stade (fig. 27). Between here and our next stop in $3.8 \mathrm{~km}$ (2.4 mi), we ascend through a gravelly end moraine of late Killey age and emerge at $\sim 184 \mathrm{~m}(\sim 604 \mathrm{ft})$ elevation on the pitted surface of an extensive outwash fan of late Killey age (sheet 1 ).

\section{STOP 3. KILLEY-AGE OUTWASH FAN}

\section{MP 62.7, Sterling Highway.}

Pull right (north) into parking area for Stop 3.

During the maximum of the Moosehorn stade, $690 \mathrm{~m}$ ( 2,265 ft) of ice stood above this site, and the terminus of Jean Lake lobe was $9 \mathrm{~km}$ ( $7.5 \mathrm{mi}$ ) northwest of here, where the glacier fronted in a huge meltwater lake that cut a prominent shoreline at a modern elevation of $\sim 100 \mathrm{~m}(\sim 330 \mathrm{ft})$ in Moosehorn-age terminal moraines (fig. 20). We will examine evidence for this lake at the next stop in Sterling and will discuss the history and ramifications of this important feature.

After the climax of the Moosehorn stade, the Jean Lake lobe collapsed, leaving numerous large blocks of dead ice that were subsequently buried by younger outwash. At this locality, outwash of Killey age built northwestward against the inside of the extensive and complex arcuate end moraine of the Moosehorn advance, burying stagnant ice masses that subsequently melted and formed numerous kettle lakes in this area (sheet 1). North of the Sterling Highway, large kettles

Figure 25. Distribution of five vegetation-cover classes at $450 \mathrm{~m}$ $(1,476 \mathrm{ft})$ elevation in the western Kenai Mountains, based on 978 random point samples measured on black-and-white aerial photographs taken in 1951 A.D. and 1996 A.D. (Dial and others, in press). are occupied by Upper Jean Lake and Dogteam Lake, which are components of a string of kettle lakes that extends northwestward $7.2 \mathrm{~km}$ (4.5 mi) from Dogteam Lake. During the Killey stade, Jean Lake lobe terminated $1.6 \mathrm{~km}(\sim 1 \mathrm{mi})$ northwest of this locality, and we will pass through that terminal moraine as we proceed westward.

On the opposite side of Hideout Hill at a distance of $4 \mathrm{~km}$ (2.5 mi) is Hidden Lake ( 72 m [ 263 ft] elevation), which provided a 330-cm (130-in) core (fig. 28) that yielded one of the first and most complete postglaciation vegetation histories in southcentral Alaska (Ager and Sims, 1981; Ager, 1983; Ager and Brubaker, 1985). The generally rock-walled, narrow lake is $7.8 \mathrm{~km}$ ( 4.9 mi) long and has a maximum depth of $\sim 42 \mathrm{~m}$

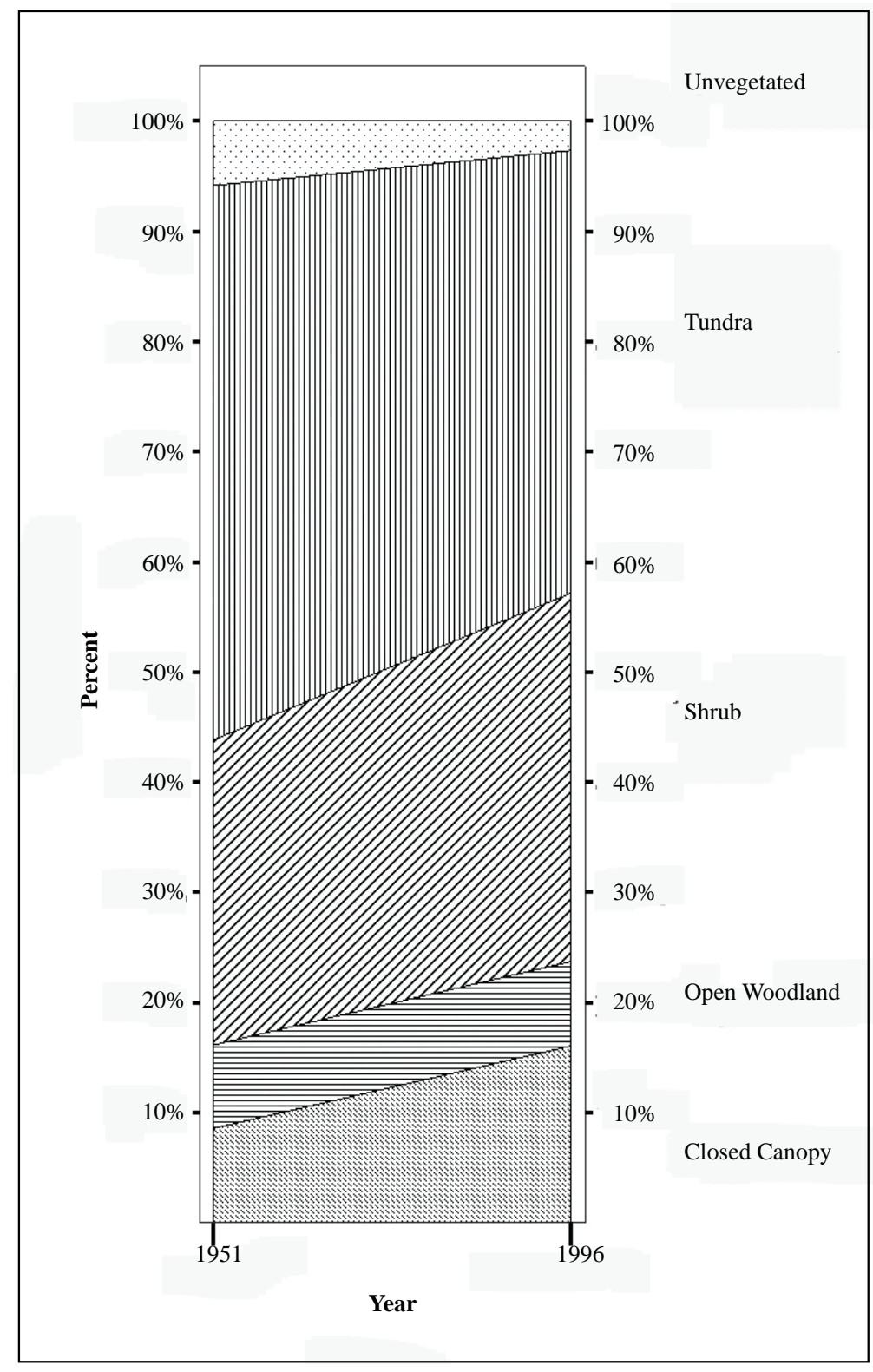




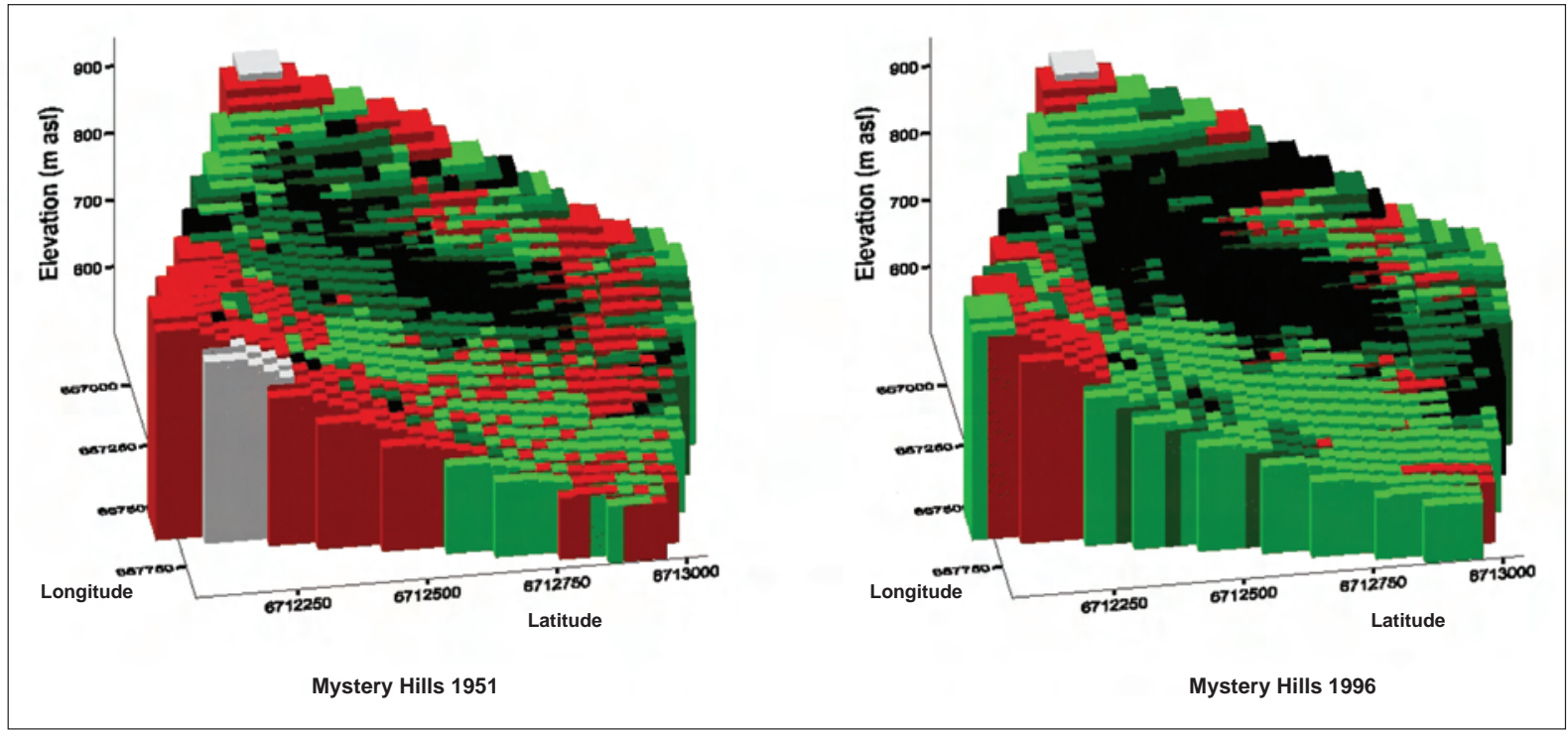

Figure 26. Relation of vegetation and topography in the Mystery Hills, western Kenai Mountains (Dial and others, in press). Areas of closed-canopy forest in the valley and shrubs on valley slopes expanded substantially between 1951 A.D. and 1996 A.D. White = rock; red = tundra; light green = shrub; olive green = open woodland; black = closed-canopy woodland. Pixel size $=30 \mathrm{~m}(\sim 100 \mathrm{ft})$. Latitude and longitude in UTM meters; elevation in meters.

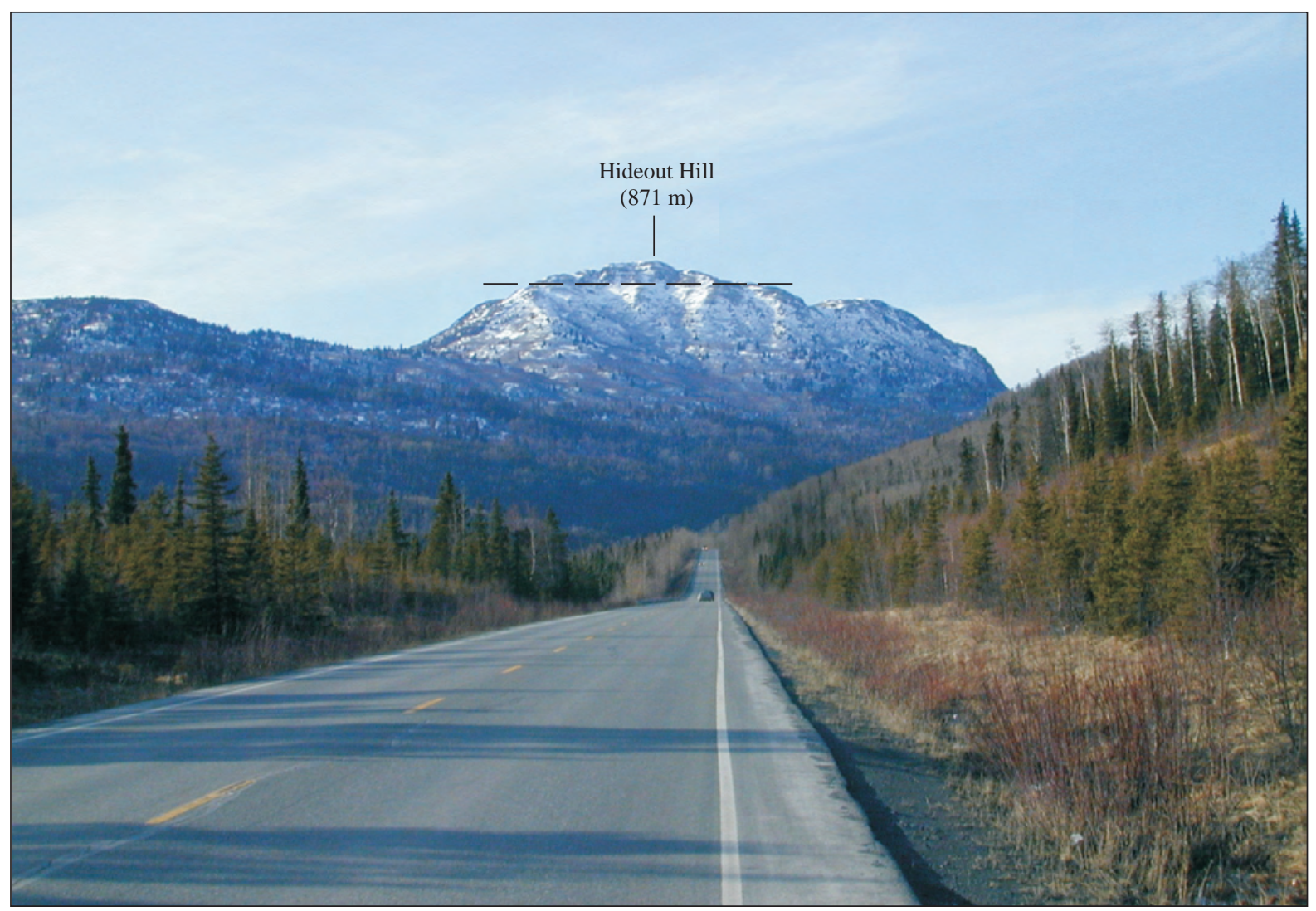

Figure 27. View northwest from MP 58.6, Sterling Highway, of Hideout Hill (871 m [2,858 ft]). Dashed line shows level ( 820 m [2,690 ft]) of glacial ice during Moosehorn stade of Naptowne glaciation (photograph taken 03-11-05). 
( 138 ft). Hidden Lake basin was filled with ice of the Hidden Lake glacial lobe during the Skilak stade of the Naptowne glaciation, and three nested morainal arcs impound the lake at its northwest end (sheet 1 ). At least 10 tephras were recovered from the Hidden Lake core, including several from near the bottom of the core (Ager and Sims, 1984), but none have been analyzed. Dating of basal gyttja (organic lake mud) from a core depth of 250-260 cm (98-102 in) demonstrates that the lake basin was deglaciated by $13,730 \pm 110 \mathrm{RC}$ ya (W-4,827) (16,352 \pm 110 cal ya) (Ager and Sims, 1981; Rymer and Sims, 1982) when thinning glacial ice withdrew southeastward through the narrow bedrock pass at the head of the lake and into the lower valley of the upper Kenai River. This important date is our best minimum-limiting date for the Skilak stade.

Following deglaciation ( 14.2-13.7 RC kya) ( 16.4- 16.3 cal kya), pollen evidence indicates that the Hidden Lake area was initially and discontinuously colonized by a tundra flora dominated by herbs, including sedges, grasses, Artemisia, and composites, and by ferns (fig. 29). The herb tundra was succeeded (13.7- 10.5 RC kya) (16.3-12.2 cal kya) by a mix of alpine tundra remnants (grasses, sedges, heather, and forbs) and an expanding moist shrub tundra dominated by dwarf birch and willows, probably in response to warmer and wetter summers. About 10.3 RC kya (12.1 cal kya), scrub poplars invaded the eastcentral Kenai Peninsula lowland, and a mosaic of diminished alpine tundra, willow-shrub tundra, and scattered poplar groves subsequently developed. This poplar-willow flora persisted until $\sim 9.5$ RC kya ( 10.7 cal kya), when alders moved in at the expense of shrub and alpine tundra assemblages and formed an alder-willow flora. About 7.8 RC kya (8.7 cal kya), boreal elements from Alaska's Interior arrived in the upper Cook Inlet region and soon spread southward into the northern Kenai Peninsula lowland. These boreal species included white and black spruce and birch, which integrated with alders in a spruce-birch-alder flora. Then, 3.0 RC kya ( 3.2 cal kya), coastal species began arriving, including mountain hemlock and Sitka spruce.

MP 63.7, Sterling Highway. Highway cuts through a remnant of the Killey-age terminal moraine of Jean Lake lobe (sheet 1).

MP 64, Sterling Highway. Highway cuts through Moosehorn-age lateral moraine of Jean Lake lobe (sheet 1).

A MP 64.5, Sterling Highway. Sterling Highway crosses an ice-marginal drainage channel between Moosehorn-age lateral moraines of Jean Lake lobe and Hidden Lake lobe (sheet 1).

MP 64.7, Sterling Highway. The route cuts through and descends the western flank of a lateral moraine that was built during the Killey stade by ice flowing northwest out of the Hidden Lake trough (sheet 1). Ahead on the western horizon, the prominent cone of Redoubt

Figure 28. Summary of pollen percentage diagram for 330 cm (130-in) Hidden Lake core (Ager, 1983, fig. 94). Ages in radiocarbon years B.P.

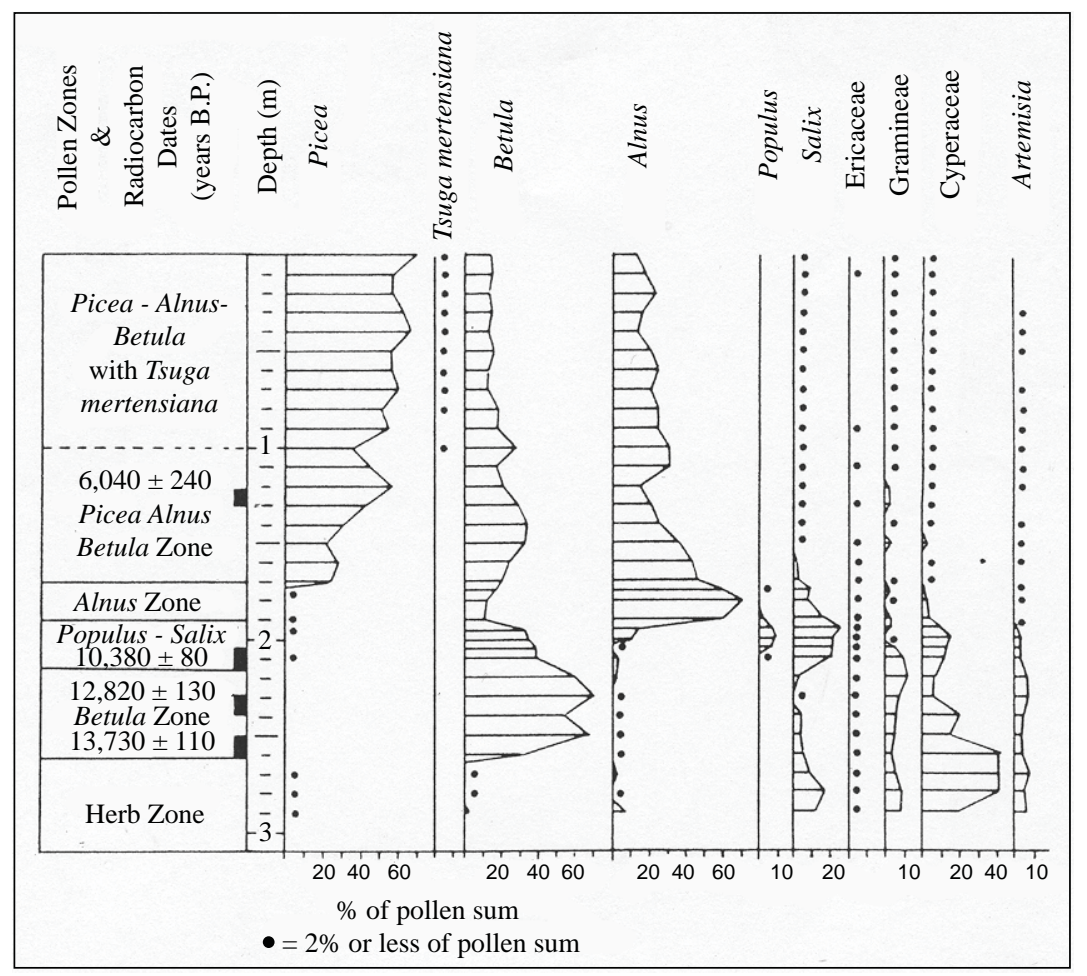


Volcano (3,108 m [10,197 ft] elevation) stands well above surrounding mountains of the southern Alaska Range across Cook Inlet. Iliamna Volcano (3,054 m $[10,020 \mathrm{ft}]$ elevation) is the other obvious cone to the left (south) of Redoubt Volcano. For the next $6.4 \mathrm{~km}$ ( $\sim 4 \mathrm{mi}$ ) we will drive west across outwash of early Skilak age related to the outermost terminal moraine on the west end of Hidden Lake (sheet 1). This pitted outwash was deposited among low hills of Killey-age drift of the Hidden Lake lobe.

MP 68.9, Sterling Highway. Access road to the south to Kelly and Petersen lakes.

MP 69.3, Sterling Highway. Sterling Highway drops down a low scarp onto a lower outwash surface related to intermediate and inner Skilak-age end moraines at Hidden Lake. This outwash train buried large blocks of Killey-age ice of the Hidden Lake lobe, which was restricted through a 1.3-km(0.8-mi-) wide pass at the head of Hidden Lake and stagnated en masse with the change to a negative glacial budget near the end of the Killey readvance, roughly $17.5 \mathrm{cal}$ kya (fig. 6). Subsequent melting of these dead ice masses produced the series of dead-ice sinks, termed a dead-ice moat by Fleisher (1986). The large depressions are occupied by Kelly Lake, Petersen Lake, and other members of the Seven Lakes chain connected by the headwaters of East Fork Moose River (sheet 1).

MP 71.3, Sterling Highway. Crossing of East Fork Moose River. A short distance $(0.4 \mathrm{~km}$ [0.25 mi]) south of Sterling Highway, Skilak-age outwash from the Hidden Lake lobe joins the Marsh Lake drainageway, a 0.6-km- (0.4-mi-) wide channel that brought meltwater from the north flank of the type Skilak stadial moraine of the Skilak Lake lobe $4.5 \mathrm{~km}$ (2.8 mi) south of Sterling Highway (sheet 1).

Distributions of former glaciers and outwash in the upper Kenai River valley and in this area clearly refute the paleodrainage model proposed by Scott (1982) and Dorava and Scott (1998), in which the upper Kenai River was diverted through Hidden Lake and East Fork Moose River and the Moose River was the main branch of the Kenai River during the Skilak stade. Those authors either ignored or did not accept the presence of Skilak-age moraines

Figure 29. Comparison of vegetation histories reconstructed from section collected near Tern Lake and core taken from Hidden Lake (extracted from Ager, 2001, fig. 6). at Hidden Lake, even though they were clearly mapped by Karlstrom (1964, sheet 4) and Reger and others (1996, sheet 2). They obviously misinterpreted the source of Skilak-age outwash from the Hidden Lake lobe, and they overlooked the deep (42 m [138 ft]), narrow lake basin that should have been filled with outwash. Clearly, both the upper Kenai River valley and the Hidden Lake basin were full of ice during the Skilak stade, and upper Kenai River did not yet exist (R.D. Reger, 2004).

For the next $5 \mathrm{~km}$ (3.1 mi) we will drive westward through Killey-age drift of the Hidden Lake and Skilak Lake lobes to a prominent interlobate moraine at MP 74.4 .

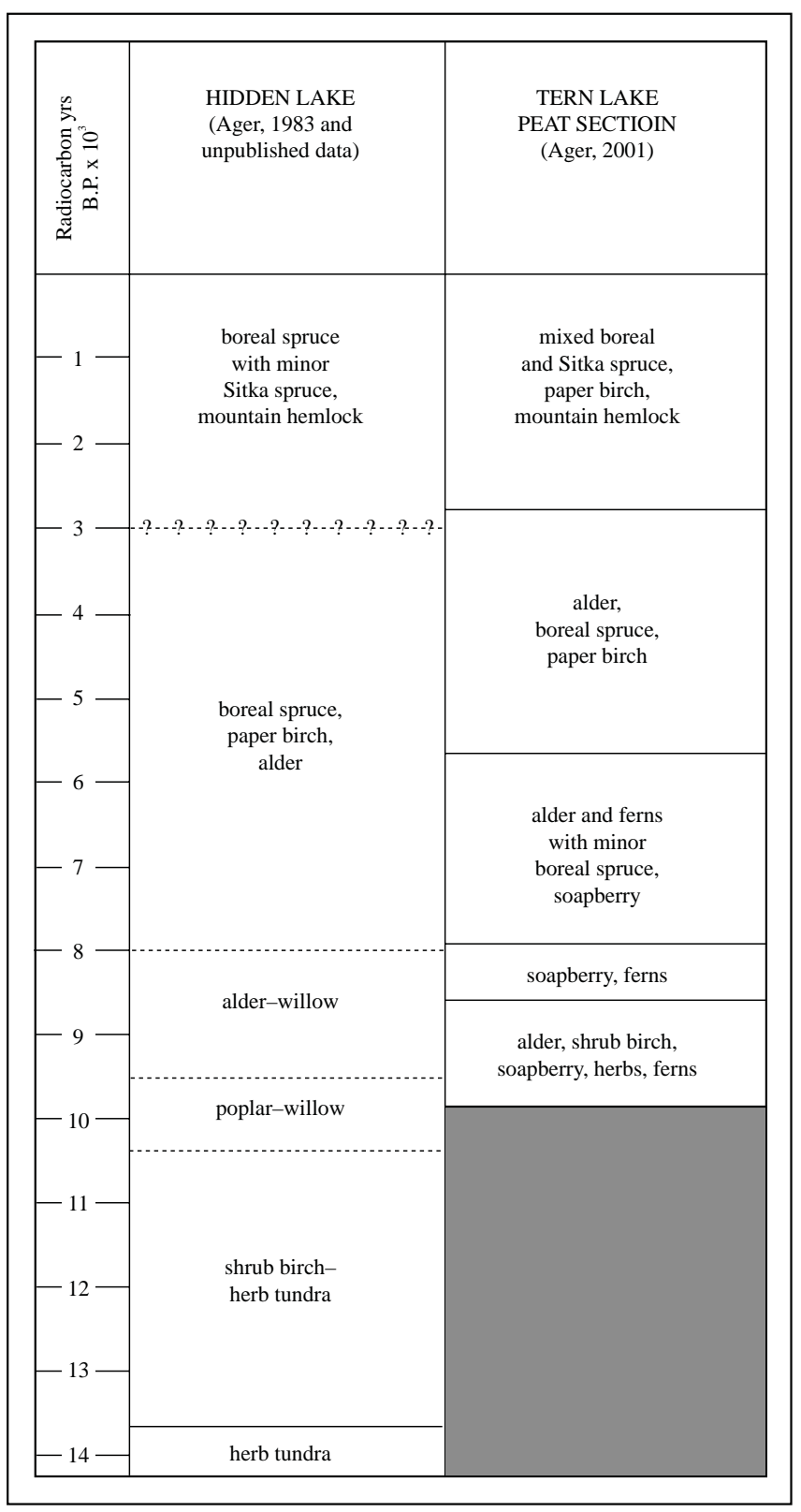


AP 75.2, Sterling Highway. Junction of Sterling Highway and west end of Skilak Loop Road. An optional side trip can be made $9.9 \mathrm{~km}$ (6.2 mi) east on Skilak Loop Road through Killey and the type Skilak stadial moraine to the west landing of Skilak Lake (fig. 19, sheets 1 and 2).

Skilak Lake (63 m [207 ft] elevation) is the second and largest meltwater lake in the Kenai River system (fig. 1). Turbid lake waters have an average depth of $73 \mathrm{~m}$ (239 ft) over an area of $99 \mathrm{~km}^{2}\left(38 \mathrm{mi}^{2}\right)$. The lake basin is divided into two sub-basins by a $>120-\mathrm{m}-(>394-\mathrm{ft}-)$ high submerged end moraine between the east and west landings (Perkins and Sims, 1983). A maximum depth of $160 \mathrm{~m}$ ( $525 \mathrm{ft}$ ) has been measured in the much larger proximal sub-basin, where the scouring glacier was confined between rock walls in the narrowest part of the lake; this depression receives some sediment from the upper Kenai River and considerable fine debris indirectly from Skilak Glacier by way of the 13-km- (8-mi-) long Skilak River. The distal sub-basin underlies the western quarter of the lake. A cobble-boulder beach lag and a modern ice-shoved rampart have formed along the present lake shoreline by wave winnowing of fine fractions from the underlying glacial deposits and by flattening and piling of the resulting coarse lag by bulldozing slabs of wind-propelled lake ice. Visible during low lake levels is a nearshore row of glacial erratic boulders that were scraped from the nearby lake bottom by wind-mobilized, drifting sheets of lake ice (fig. 30).

Skilak Lake is the site of an interesting experiment in varve analysis. Of 13 piston cores collected by Perkins and Sims (1983) from the lake bottom, all but one were judged unacceptable for varve analysis because of widespread bottom-current effects and an inability to reliably separate individual varves. The single core with clearly defined sediment layers was collected from a depth of

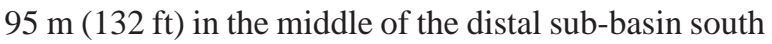
of the west landing. Disturbance of the core during sampling required calibration of the layers, which were considered to be annual by Perkins and Sims (1983), using the 1935 A.D. tephra from Augustine Volcano as a key marker. Thicknesses of 237 couplets were measured and thought to represent layers deposited from 1698 A.D. through 1934 A.D. Trends in varve thickness were found to positively correlate with trends of mean annual temperature from as far away as northwestern Washington state and to negatively correlate to a high degree with mean annual cumulative snowfall in southern Alaska. Perkins and Sims (1983) estimated that the mean annual rate of sedimentation represented by the sequence is 5 $\mathrm{mm}$ (0.2 in) per yr. In a test of this methodology, Stihler and others (1992) used radioisotopes ${ }^{137} \mathrm{Cs}$ and ${ }^{210} \mathrm{~Pb}$ and tephrochronology to demonstrate that the mean annual

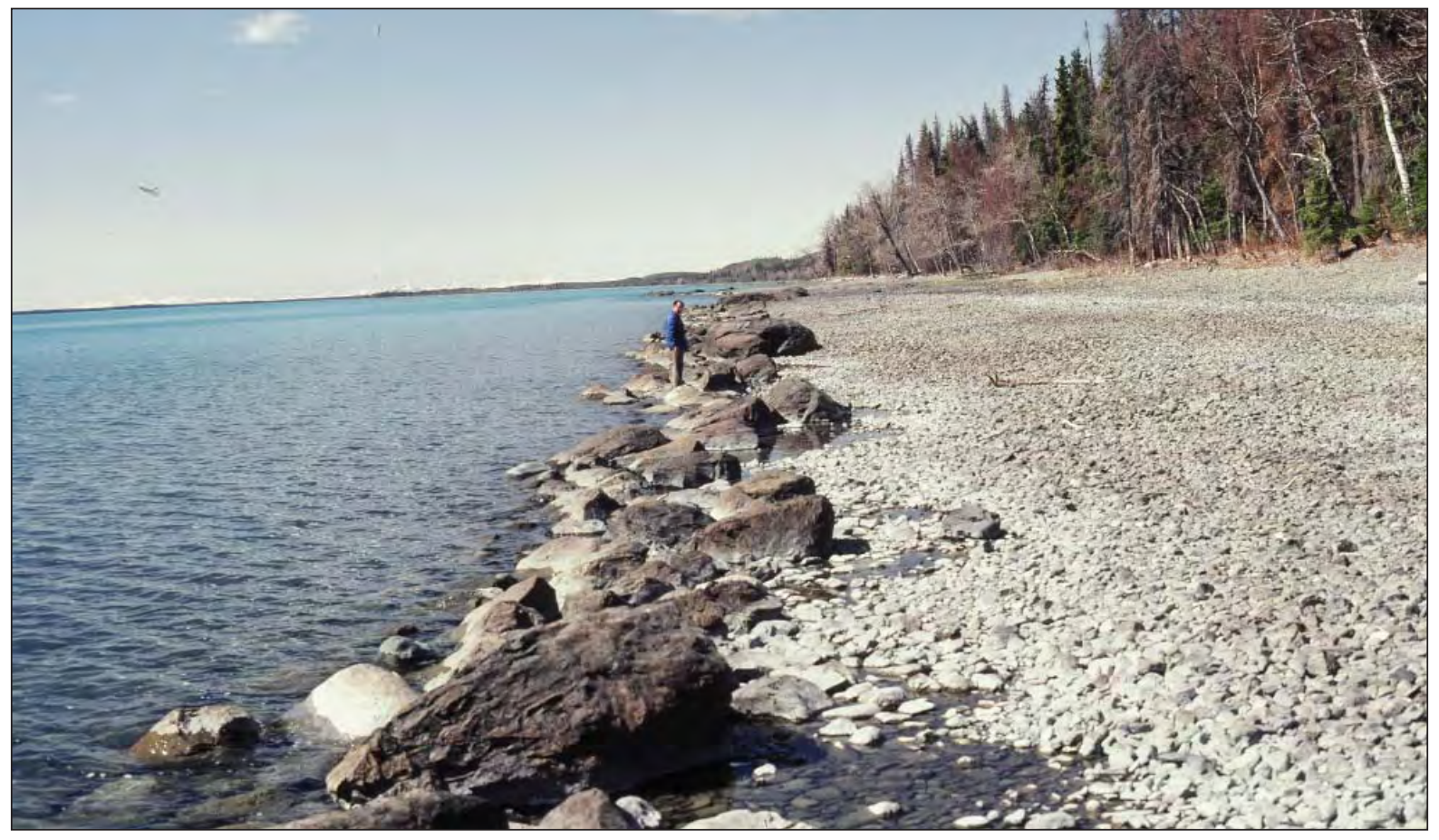

Figure 30. View west from east landing at Skilak Lake, showing 2- to 3-m- (6.5- to 10-ft-) wide row of erratic boulders and blocks pushed into place by drifting lake ice about $2.5 \mathrm{~m}$ (8.2 ft) below highest summer lake level (photograph taken 5-20-85). 
sedimentation rate in Skilak Lake has been an order of magnitude less than $5 \mathrm{~mm}$ (0.2 in) per yr and that sediment layers do not represent annual events. Thus, climatic reconstructions by Perkins and Sims (1983) based on these layers are invalid, and considerable caution is advisable when counting varves to ensure that each couplet represents annual sedimentation.

Skilak Lake is dammed at the west end by a set of two end moraines that represents the type moraine of the Skilak stade (fig. 31). Associated with each moraine is a pitted outwash terrace, indicating that debris-charged proglacial streams of the time buried nearby stagnant masses of Killey-age ice. The inner moraine of Skilak age and its associated sand dunes are notched by a former shoreline that is related to a series of ice-shoved pebble-cobble ramparts (sheet 2). The age of this higher lake level is unknown, except that it postdates the inner Skilak end moraine.

The lower Kenai River begins at the west end of Skilak Lake and initially flows through the impounding end moraines. Distinctive, large, crescentic to transverse linear gravel bars (megaripples) are preserved in the initial $6.1 \mathrm{~km}$ (3.8 mi) of the lower Kenai River (sheet 2, fig. 32). These channel features stand in relief up to $5 \mathrm{~m}$ (16 ft) above the riverbed, measure 15 to $30 \mathrm{~m} \mathrm{(} \mathrm{50} \mathrm{to}$ $\sim 100 \mathrm{ft}$ ) wide (chord lengths), and reach lengths of 120 to $240 \mathrm{~m}$ (400 to $800 \mathrm{ft}$ ). They remain unmodified in aerial photographs taken over a period of $27 \mathrm{yrs}$, when at least one significant outburst flood event occurred in 1974 A.D. (Scott, 1982, p.17-18), and clearly do not represent the modern river regimen. We suggest that large-magnitude floods produced by sudden drainage of glacier-impounded lakes to the east emerged here from beneath Skilak Lake lobe and raced down the lower Kenai River, forming the large current ripples during conditions of extraordinary river flow in the flood channel when the terminus of Skilak Lake lobe stood nearby, probably at the inner end moraine.

Double outwash terraces related to inner and outer end moraines of Skilak age and the presence of long-preserved megaripples in the channel of lower Kenai River clearly indicate that the lower Kenai River has long been a major drainageway for the Skilak Lake lobe, further arguing against the drainage model proposed by Scott (1982) and Dorava and Scott (1998). At Sterling we will discuss other evidence that the lower Kenai River course actually developed during the Killey stade.

MP 77.7, Sterling Highway. Leaving Killey terminal moraine and entering Moosehorn terminal moraine of Skilak Lake lobe. We will discuss the Killey stade of the Skilak Lake lobe at Stop 4 in 4.5 km (2.8 mi).

MP 80, Sterling Highway. Overlook of Sterling area from type Moosehorn stadial moraine of Skilak
Lake lobe (sheet 2). This prominent arcuate terminal moraine marks the maximum extent along the Sterling Highway of ice from the Kenai Mountains during the Naptowne glaciation. We descend west down the frontal slope of the terminal moraine and cross a subdued bench underlain by till of a pre-Naptowne glaciation, which probably occurred between $\sim 100$ kya and $\sim 45$ kya (Hamilton,1994). Compositions of till stones indicate that the source of this pre-Naptowne till is the Kenai Mountains to the southeast.

\section{STOP 4. STERLING}

MP 80.5, Sterling Highway. Turn left (south) into large parking area for Stop 4.

At this site we are in an extensive lowland between the type Moosehorn terminal moraine of the Skilak Lake lobe to the east, which we just traversed, and a Moosehorn-age terminal moraine (the low ridge $2.4 \mathrm{~km}$ [ 1.5 mi] to the northwest) that was deposited by a broad lowland ice sheet derived from northern sources (sheet 2). We believe that ice from northern and western sources advanced upon Kenai Peninsula lowland fairly quickly across the regional lake in the Cook Inlet trough during the waxing phase of the Moosehorn stade (fig. 6). Physiographic evidence indicates that this composite ice sheet initially blocked the drainage of ancestral Kenai River where the ice sheet impinged against low hills of pre-Naptowne drift south of the present course of Kenai River to our southwest (sheet 2). Evidence for the relatively late arrival of ice from the Kenai Mountains includes lack of outwash in front of terminal moraines southeast of the Moose River and extensive notching at $\sim 100 \mathrm{~m}(\sim 320 \mathrm{ft})$ modern elevation of terminal moraines of the Jean Lake, Hidden Lake and Skilak Lake lobes, which apparently fronted in the 100-m (320-ft) lake at its higher levels and were attacked by wave action (sheets 1 and 2). Other evidence of this extensive lake is preserved today as the low bench across the Sterling Highway to the north. The subdued morphology of this extensive bench, which forms the floor of the former lake basin southeast of the Moose River along the front of the terminal moraines, was formed through erosion by waves and currents in the impounded lake. The bench is discontinuously underlain by fairly thin pebbly lakebottom sands as a result of winnowing and reworking of the glacial deposits by waves and currents (fig. 33). Subsurface data indicate that sandy to clayey lake deposits are also present in this former lake basin (Munter and Maurer, 1991), although we have little information about their distribution.

An important ramification of lake impoundment in the Sterling area was diversion of the lower Kenai River during the Moosehorn stade, when lake waters 


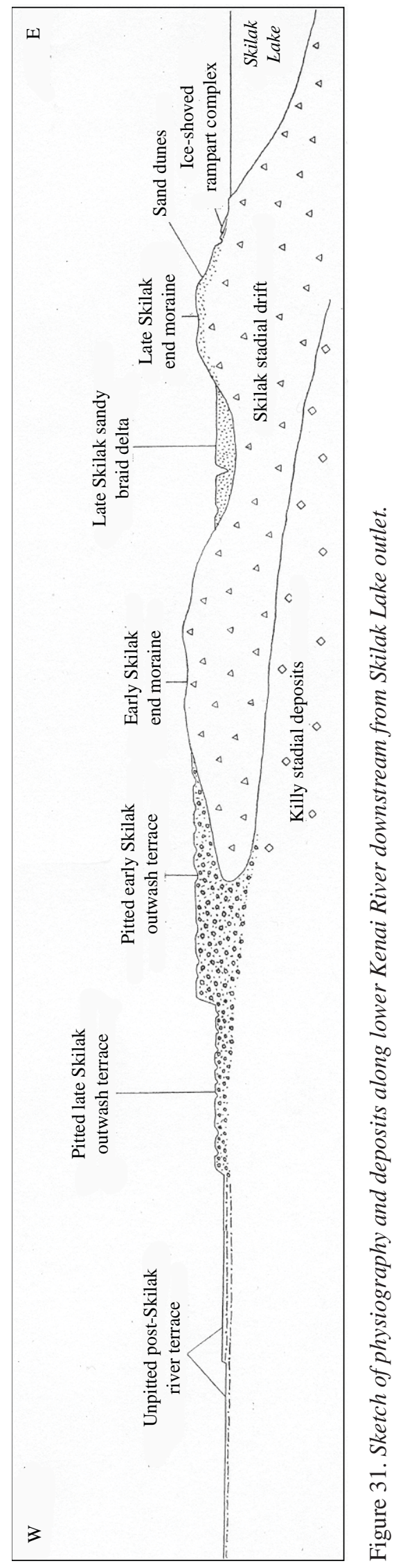




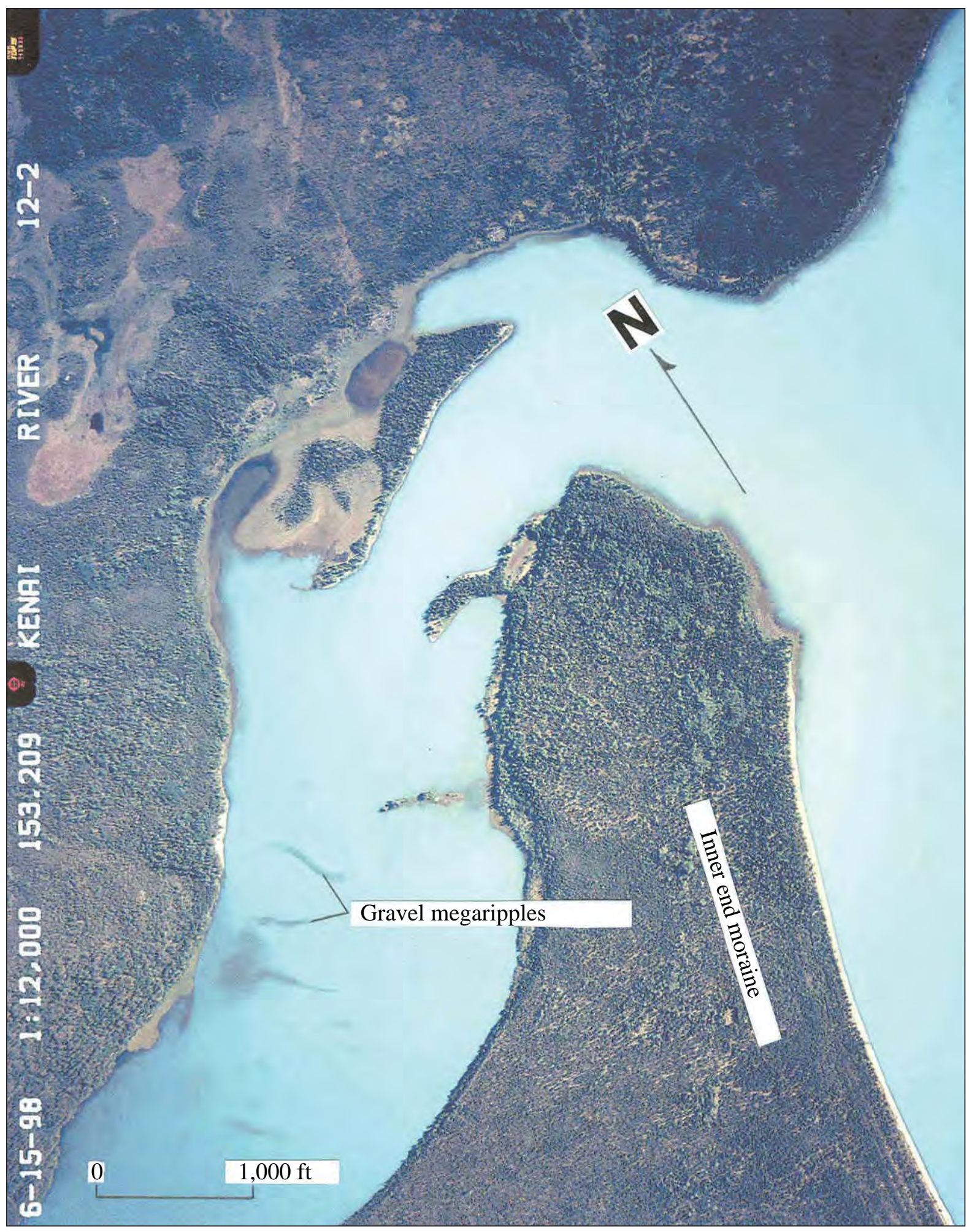

Figure 32. Gravel megaripples preserved in Kenai River below Skilak Lake outlet. Note rows of ice-shoved ramparts in lower right corner. 
overflowed a low divide at $\sim 100 \mathrm{~m}(\sim 330 \mathrm{ft})$ modern elevation in pre-Naptowne drift south of the modern lower Kenai River (sheets 2 and 3). Overflow initially took a subglacial course at $\sim 95-100 \mathrm{~m}(\sim 310-330 \mathrm{ft})$ elevation along the margin of the lowland ice sheet and then cut an obvious linear channel (diversion channel $\mathbf{A}$ in sheet 3) through pre-Naptowne drift toward the southwest, where it joined ice-marginal drainage along the north flank of the Tustumena Lake lobe (fig. 34). Clear evidence that this diversion channel was active when glacial ice was present is the large kettle preserved in channel $\mathbf{A}$ where it changes course to the southwest (sheet 3). Physiographic relations suggest that a meltwater lake trapped between the Tustumena Lake lobe and ice from the northwest probably formed nearby at $\sim 90-\mathrm{m}(\sim 295-\mathrm{ft})$ elevation, and we speculate that the $90-\mathrm{m}$ (295-ft) lake probably drained subglacially to the southwest through the gap now occupied by lower Coal Creek (fig. 34).

A shift to a negative budget in greatly expanded Cook Inlet glaciers $\sim 23 \mathrm{cal}$ kya following the climax of the Moosehorn advance caused the lowland ice sheet (from northern sources) to thin and retreat from its maximum

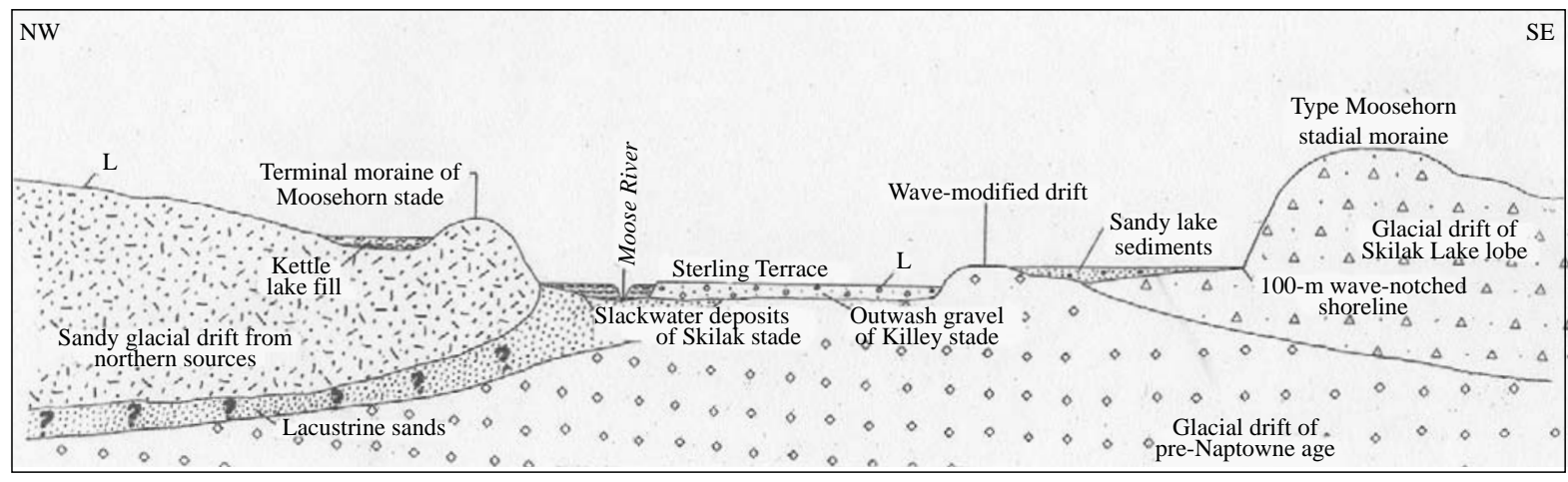

Figure 33. Sketch of physiography and near-surface stratigraphy in Sterling area (after Munter and Maurer, 1991, sheet 3).

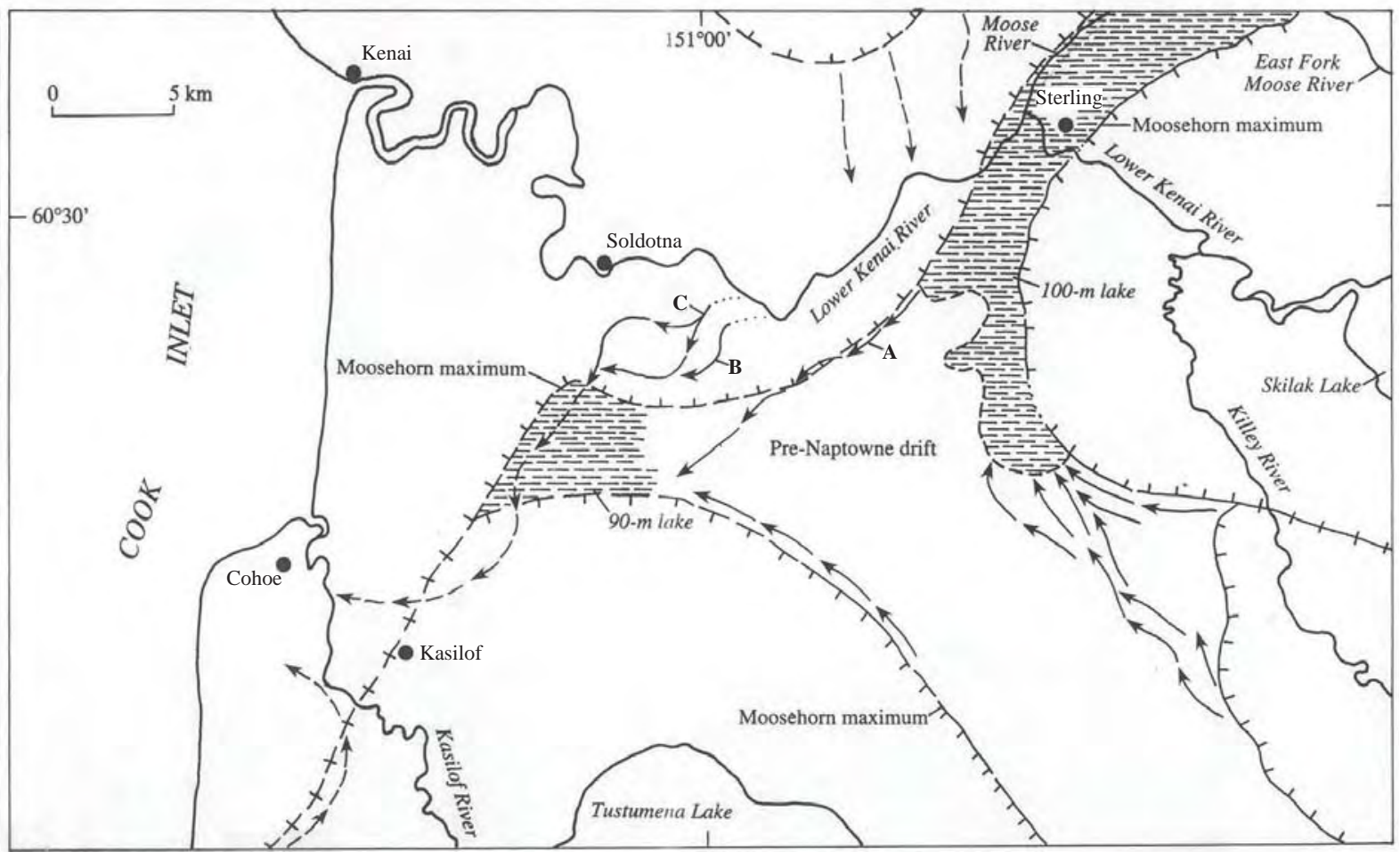

Figure 34. Early evolution of lower Kenai River at and just after culmination of Moosehorn advance. Solid arrows indicate early Moosehorn drainage course: relative ages $\boldsymbol{A}>\boldsymbol{B}>\boldsymbol{C}$. Dashed paleodrainage segments are approximations; dotted segments are inferred (modified from Reger and Pinney, 1997, fig. 4). 
position. In response, the diversion course of ancestral Kenai River shifted northwestward and occupied two successive channels (designated B and C, fig. 34 and sheet 3). Channel $\mathbf{B}$ has a modern threshold elevation of 80-85 m ( 260-280 ft), and channel C has a modern threshold elevation of $\sim 60-65 \mathrm{~m}$ ( $\sim 200-213 \mathrm{ft})$. The youngest diversion channel $(\mathbf{C})$ preserved in the uplands south of Soldotna forms the former drainageway now occupied by Headquarters Lake as well as the aligned segments of the underfit upper courses of Slikok Creek and Coal Creek between Soldotna airport and Kasilof (sheet 3). We propose that, later in early post-climax Moosehorn time, the lowland ice sheet pulled back from the highlands south and southeast of Soldotna, forming a moat between the ice front and the uplands that eventually redirected lower Kenai River northwestward along its modern course. In support of this proposal, we have identified early post-climax to middle Moosehorn-age, high-level terrace remnants of the early post-diversion channel just below the threshold of channel $\mathbf{C}$ southeast of Soldotna airport and along the east wall of the lower valley of Slikok Creek (sheet 3). A correlative terrace remnant is located on the high bluff northwest of the lower Kenai River southwest of Scout Lake (sheet 2).

Although we are standing where very cold, turbid meltwater in the $100-\mathrm{m}$ (330-ft) lake was once $35 \mathrm{~m}$ (115 ft) deep, today the Sterling Highway crosses a gravel outwash terrace that we informally call the Sterling Terrace, which is the highest extensive terrace of the lower Kenai River terrace set (fig. 35). The Killey age of Sterling Terrace and initial development of the lower Kenai River drainage in the Sterling area are demonstrated by direct tracing of this outwash terrace headward to the southeast through the type Moosehorn terminal moraine into the outer part of the younger Killey terminal moraine (sheet 2) (R.D. Reger, 2004). Above till of the pre-Naptowne glaciation, gravels of the Sterling Terrace are 3 to $9 \mathrm{~m}$ (10 to $30 \mathrm{ft}$ ) thick and are blanketed by 45 to $60 \mathrm{~cm}$ (17 to 24 in) of loess (fig. 36). We typically find Lethe tephra in the lower part of the loess. Mass accumulation rates of late Quaternary loess in Kenai Peninsula lowland range from $\sim 0.7$ to $2.6 \mathrm{~mm}$ ( .03 to .10 in) per century (Muhs and others, 2003, table 5). For the next $2.4 \mathrm{~km}$ (1.5 mi) we will drive across the Sterling Terrace to the crossing of Moose River. We will discuss the Skilak-age terrace of the lower Kenai River terrace set at Soldotna.

MP 82, Sterling Highway. Crossing of lower Moose River, the largest clearwater tributary of lower Kenai River. Moose River generally parallels the Moosehorn-age terminal moraine of the lowland composite glacier from northern sources (sheet 2) and is cut into the Sterling Terrace (fig. 33). Slackwater rhythmites of probable Skilak age were found below an elevation of $\sim 55 \mathrm{~m}(\sim 180 \mathrm{ft})$ in sandy terrace deposits $1.9 \mathrm{~km}$ (1.2 mi) upstream from the Moose River bridge (fig.37). Relatively thick layers of clean fine to medium sand are locally cross bedded and thinner layers are fine sand with some silt. Lethe tephra was not found in these deposits, perhaps indicating that they are Skilak in age. Individual layers in these slackwater rhythmites may

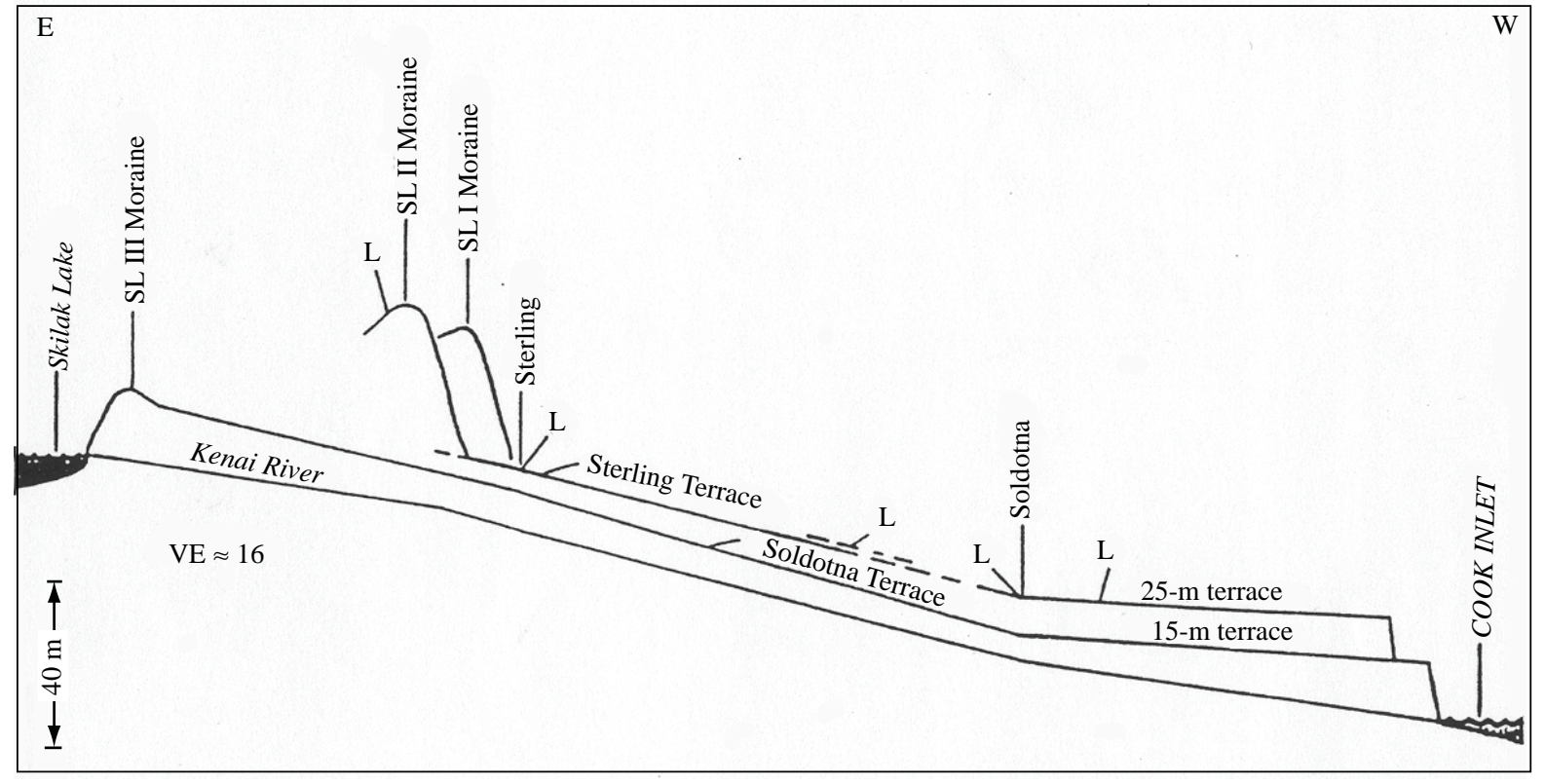

Figure 35. Relations of outwash terraces of the lower Kenai River set and moraines of the Skilak Lake (SL) lobe. Lethe tephra (L) is present on landforms of late Killey and older ages (Reger and Pinney, 1997, fig. 3). 
document separate outburst floods (Waitt, 1980, 1985) or multiple flood pulses during several outburst floods (Smith, 1993) down lower Kenai River during the Skilak stade. In either case, evidence that the main proglacial drainage during the Skilak stade was down lower Kenai River and not Moose River refutes the paleodrainage model advocated by Scott (1982) and Dorava and Scott (1998).

The top of weakly consolidated Pliocene sandstone of the Sterling Formation is at $\sim 30$ to $40 \mathrm{~m}(\sim 100$ to 130 $\mathrm{ft}$ ) elevation in this area, $\sim 12$ to $20 \mathrm{~m}$ ( $\sim 40$ to $65 \mathrm{ft}$ ) below the ground surface (Munter and Maurer, 1991, sheet 3). Erosion of this sandstone by glaciers and streams is indicated by the presence of distinctive, small siderite (iron-stone) concretions, which form in the Sterling Formation, in gravel bars of the lower Kenai River $11 \mathrm{~km}$ ( $\sim 7 \mathrm{mi})$ downstream from here.

Archeological investigations at the Moose River site (KEN-043) on the low terrace east of the mouth of Moose River document seven house pits and associated midden material. Evidence recovered during excavations attributes these occupations primarily to the Riverine Kachemak culture between 1.5 and 2.5 RC kya (1.4 and 2.6 cal kya) (D.R. Reger, 2004), except for a small collection of Denaina artifacts from one house pit (D.R. Reger, oral commun., 4/16/07). The inventory of recovered artifacts includes numerous large spalls from local river cobbles and notched pebbles as well as chipped stone and ground slate implements likely related to the processing of salmon. Identifiable faunal remains indicate that the residents consumed salmon, moose, snowshoe hare, and red squirrel. Excavations directly across lower Kenai River at the extensive Nilnunqa site (KEN-066) recovered evidence of two or three occupations by Riverine Kachemak people between $~ 1.6$ and $\sim 1.0$ RC kya ( 2.5 and 0.9 cal kya) and later occupation by Denaina people from $\sim 0.9$ RC kya ( 0.8 cal kya) into the post-contact period (D.R. Reger, 2004). The Nilnunqa artifact inventory is very similar to collections from the Moose River site.

MP 82.6, Sterling Highway. The highway cuts across a peat-filled embayment of a former large kettle lake in Moosehorn moraine derived from northern sources. A hole drilled in this embayment penetrated $3.8 \mathrm{~m}(12.5 \mathrm{ft})$ of peat and

Figure 36. Stratigraphic section through deposits of the Sterling Terrace at Sterling (Reger and others, 1996, fig. A27). bottomed in peat (Reger and others, 1996, fig. A25). The peat bog in the drained lake basin north of the Sterling Highway is now thoroughly invaded by black spruce.

A MP 83.4, Sterling Highway. Junction of Sterling Highway, east end of Scout Lake Loop Road, and Swanson River Road. An optional side trip can be taken north 50 km (31 mi) on Swanson River Road and other public roads through deposits of late Moosehorn age in the Kenai National Wildlife Refuge (sheet 2). Near Silver Lake (fig. 38), Walsh and others (1995) documented subsurface evidence of liquefaction during the M9.2 Alaska earthquake of March 27, 1964, including ground cracking, clastic dikes, and evidence of sand fountaining. Several lakes, ponds, ands fens have been sampled in this area for evidence of past climatic change (fig. 38).

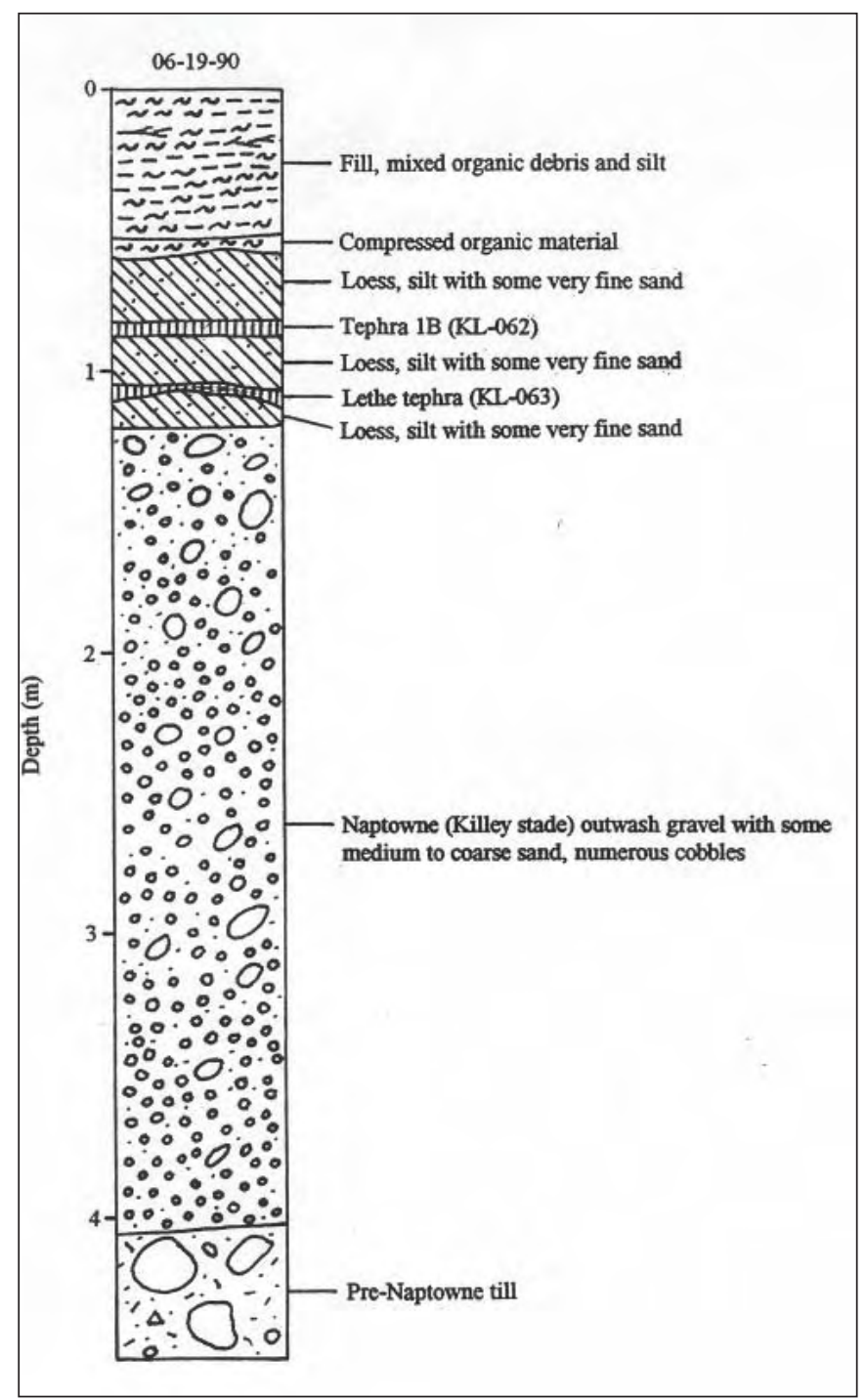




\section{SWANSON RIVER ROAD LOCALITIES}

\section{PARADOX LAKE}

Paradox Lake is the site of the most comprehensive paleoclimatic study using proxy data in the Kenai Peninsula lowland. Long (885-cm [29-ft]) and short (70-cm [2.3-ft]) cores were retrieved from the lake by Anderson and others (2006) and analyzed for sediment content, magnetic susceptibility, plant macrofossils, and pollen, spore, and charcoal contents. A chronology was established using ${ }^{210} \mathrm{~Pb}$ in the younger part of the cores and 11 AMS radiocarbon dates in the rest of the cores. The pollen diagram (fig. 39) is divisible into four zones similar to zones recognized in the region by Ager and Sims (1981), Ager (1983, 2000, 2001), Ager and Brubaker

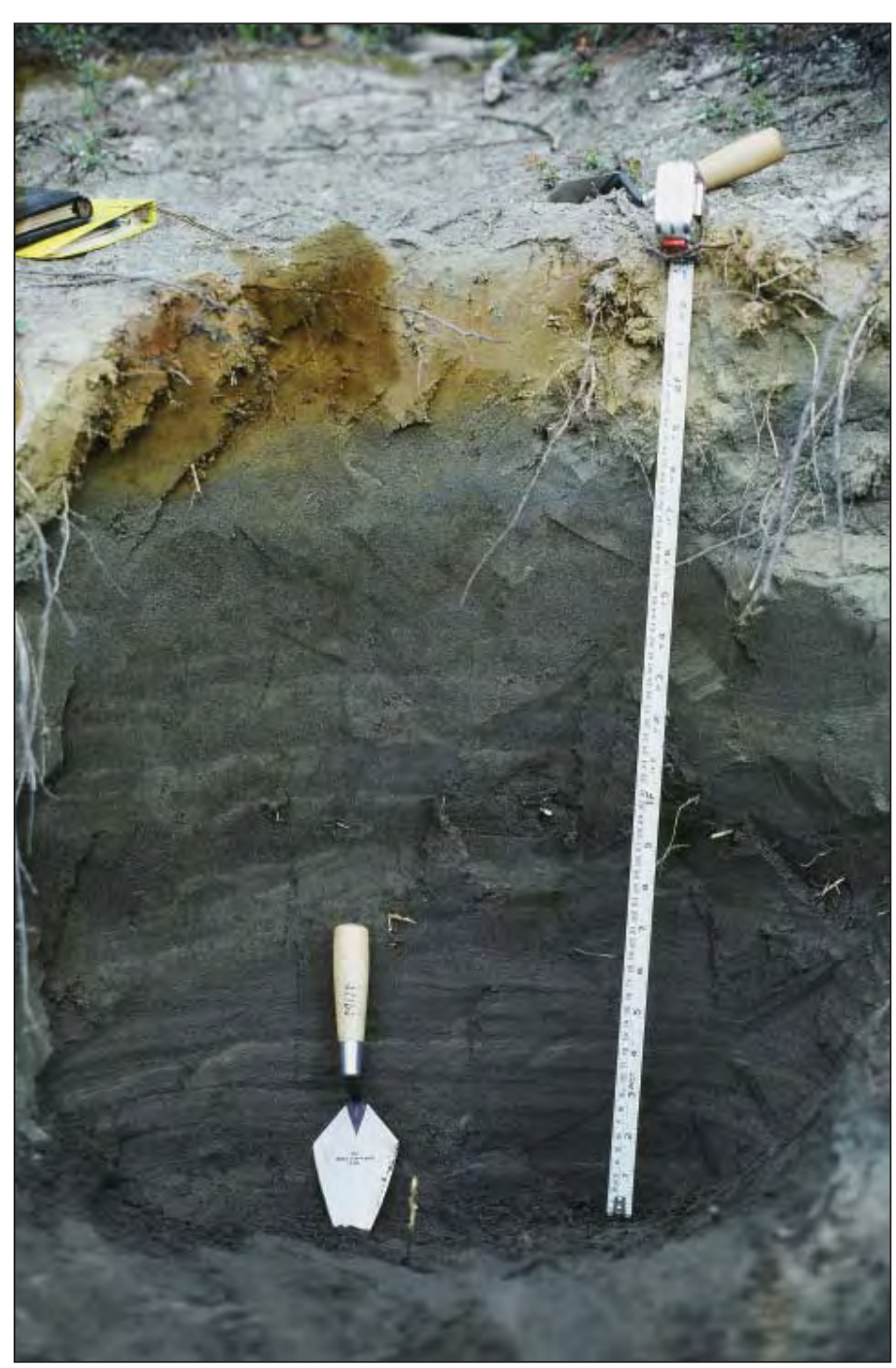

Figure 37. Sandy slackwater rhythmites in Skilak-age terrace of lower Moose River (photograph taken 6-21-90).
(1985), Ager and others (1985), and Ager and Cararra (2006). Wildfire history was reconstructed from highresolution sediment-charcoal analyses in which peaks represent charcoal deposited in the Paradox Lake basin during nearby wildfires (fig. 40). At least 109 tephras are present in the lake-bottom sediments, an unusually high number of tephras in a single lake basin (de Fontaine and others, 2007). The oldest tephra dates $\sim 12.9 \mathrm{cal} \mathrm{ka,}$ and peak frequency of tephra fall is between $\sim 7.0$ and $\sim 9.0$ cal kya.

The history of vegetation evolution in the Paradox Lake area is intermediate between histories proposed for the northern Cook Inlet region by Ager and Brubaker (1985) and proposed for southern Kenai Peninsula by Ager (2000), and, except for hemlock, is similar to the Hidden Lake record (Ager and Sims, 1981; Ager, 1983). Between $\sim 13$ kya and $\sim 10.7$ cal kya shrub tundra existed in the Paradox Lake area, and the influx of pollen and spores was relatively low (figs. 39 and 41). Sedges, grasses and Artemisia were at their Holocene maxima, and the incidence of wildfire was relatively low. About $10.6 \mathrm{cal} \mathrm{kya,}$ large willow shrubs and poplar trees moved into the area, and the frequency of wildfires increased. A shift to a warmer and drier climate between $\sim 10.0$ and $9.6 \mathrm{cal}$ kya is indicated by a long-term change to generally higher pollen and spore influxes, development of lakeside sphagnum bogs, the arrival of significant alder shrubs, lower lake levels, and a relatively high incidence of wildfires. This warming occurred slightly later than the Holocene thermal maximum in northwestern Alaska but is coeval with the Holocene thermal maximum in southwest Alaska (Kaufman and others, 2004). Mixed white spruce and tree birch arrived at Paradox Lake $\sim 8.5 \mathrm{cal} \mathrm{kya}^{8}$, probably in response to climatic amelioration. There are indications

\footnotetext{
${ }^{8}$ Anderson and others (2006) used criteria developed by Hansen and Engstrom (1985) to separate pollen of white and black spruce. Until recently, palynologists could not reliably separate pollen of shrub birch and tree birch, but criteria were developed by Clegg and others (2005). Clegg and others (2005) and Anderson and others (2006) used taxonomy proposed by the Flora of North America Editorial Committee (FNA) (1997) for tree birch and Betula range maps. B. papyrifera var. humilis (Alaska paper birch) was formerly considered the boreal birch tree in Alaska and was mapped in northern Kenai Peninsula lowland, and Kenai birch (B. papyrifera var. kenaica) was regarded as a separate variety widely distributed on the Kenai Peninsula (Viereck and Little, 1972). FNA (1997) now limits B. papyrifera to the Yukon and B. neoalaskana to interior Alaska, and regards Kenai birch (B. kenaica) as the only species of tree birch on Kenai Peninsula.
} 


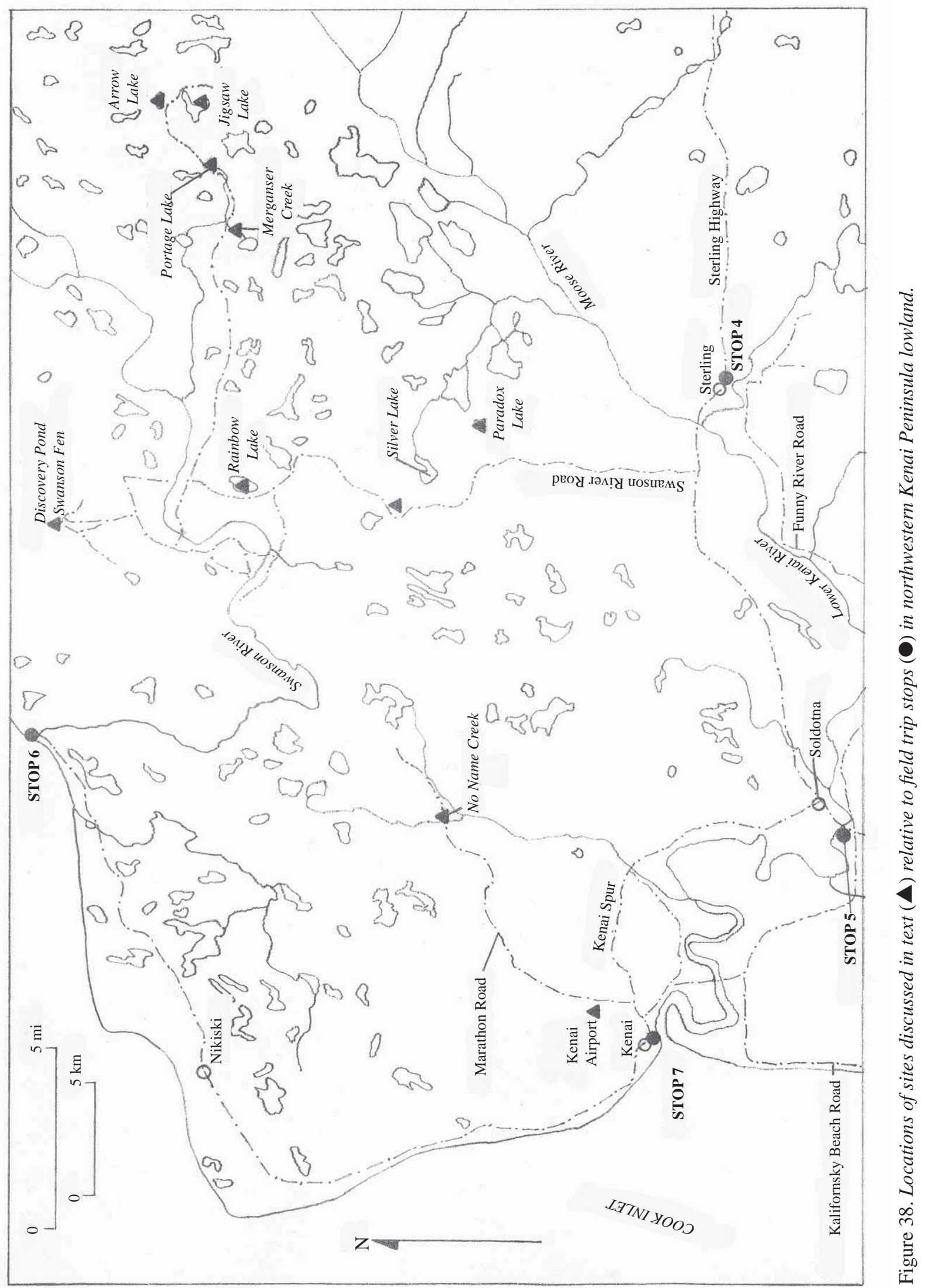




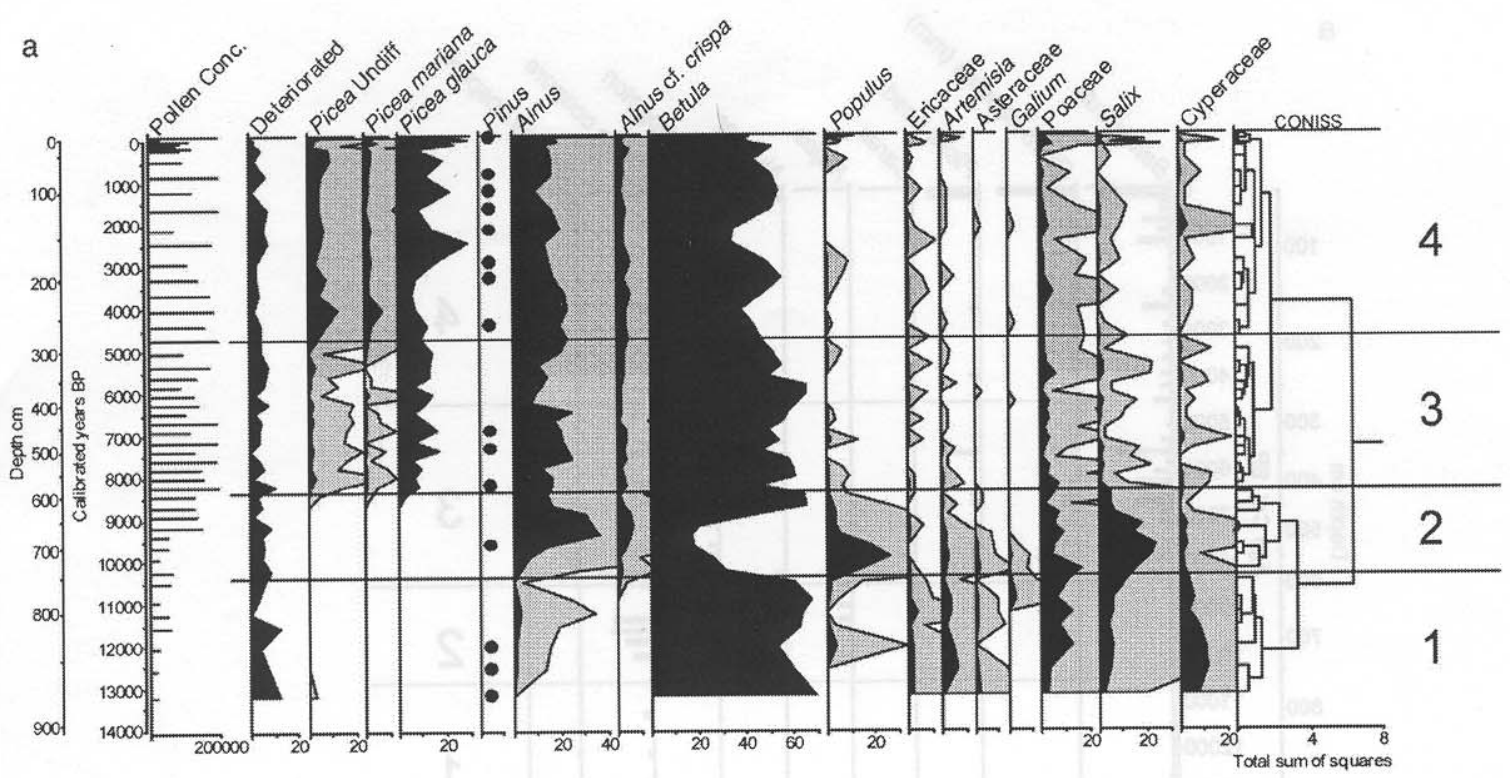

b

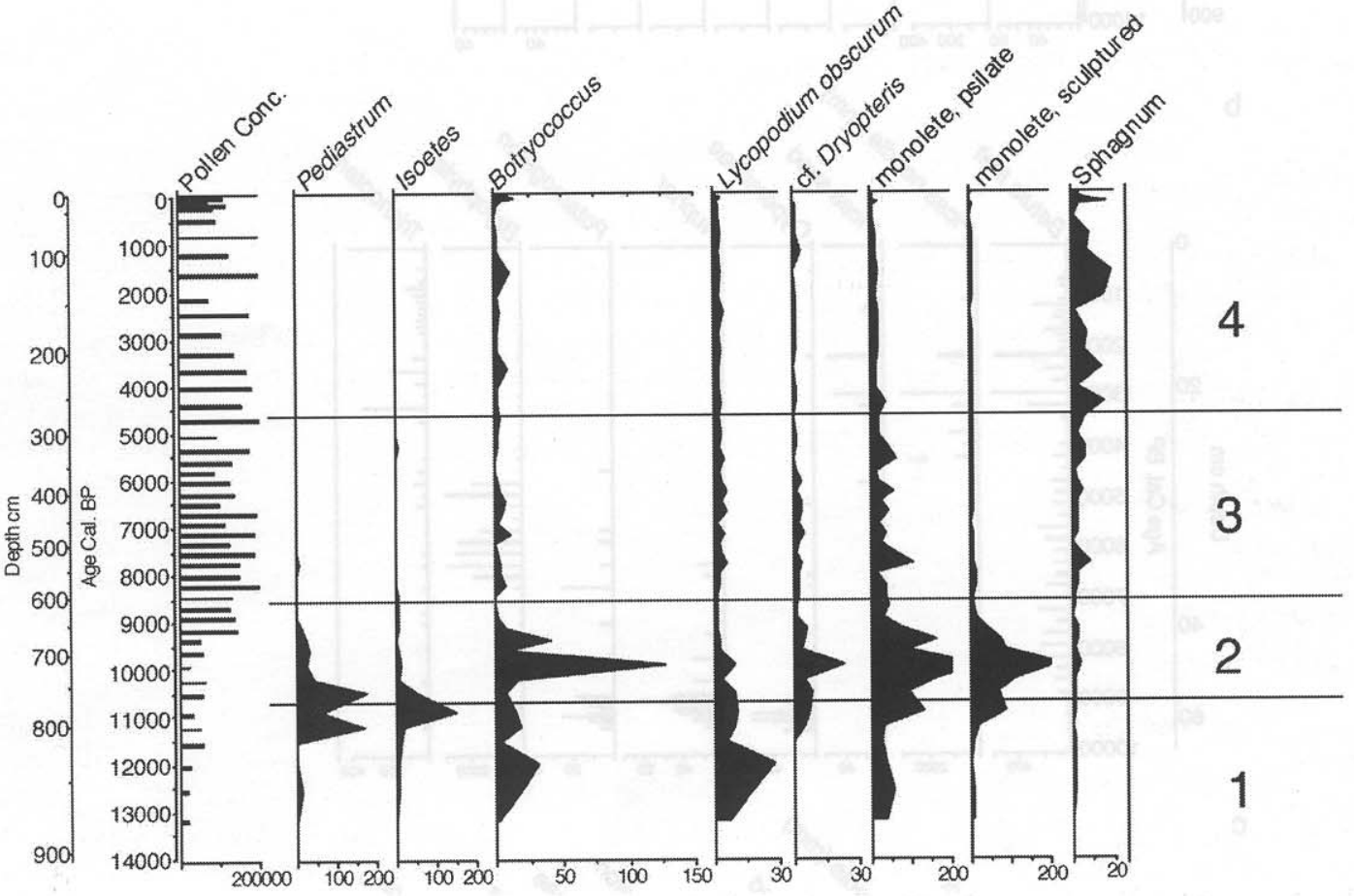

Figure 39. Pollen (a) and spore (b) percentage diagrams for Paradox Lake cores (Anderson and others, 2006, fig. 6). 
that lake levels began to rise $~ 8.0$ cal kya in northern Kenai Peninsula lowland, perhaps signaling the onset of a cooler, wetter climate (Anderson and others, 2006, p. 796), and by $\sim 4.5$ cal kya this climate regimen produced a lowland invasion by black spruce, widespread paludification causing an expansion of sphagnum bogs, and lower incidences of wildfires (fig. 41).

\section{RAINBOW LAKE}

New sedimentary biogenic silica and chironomid records from Rainbow Lake (fig. 38) argue for a midHolocene thermal maximum (F.S. Hu and G. Clarke, 2007, pers. commun.). Biogenic silica measures lake productivity as represented by diatoms, which increases with warmer water. Chironomid (midge) community composition is likewise largely dependent on water temperature.

\section{Discovery POND}

Discovery Pond is a small, 4-m-deep pond near the site of the first well drilled in the Swanson River oilfield (fig. 38). Analyses of four (3.6- to 6.1-m-long) cores collected in 2002 A.D. by R Scott Anderson, Darrell Kaufman, Al Werner and their students show that peat began accumulating in that kettle 13.4 cal ka (fig. 42). During the Younger Dryas (12.7 to $11.5 \mathrm{cal} \mathrm{ka)}$ this kettle was flooded. Ecological indicators of openwater conditions (e.g., Pediastrum and Isoëtes, as well

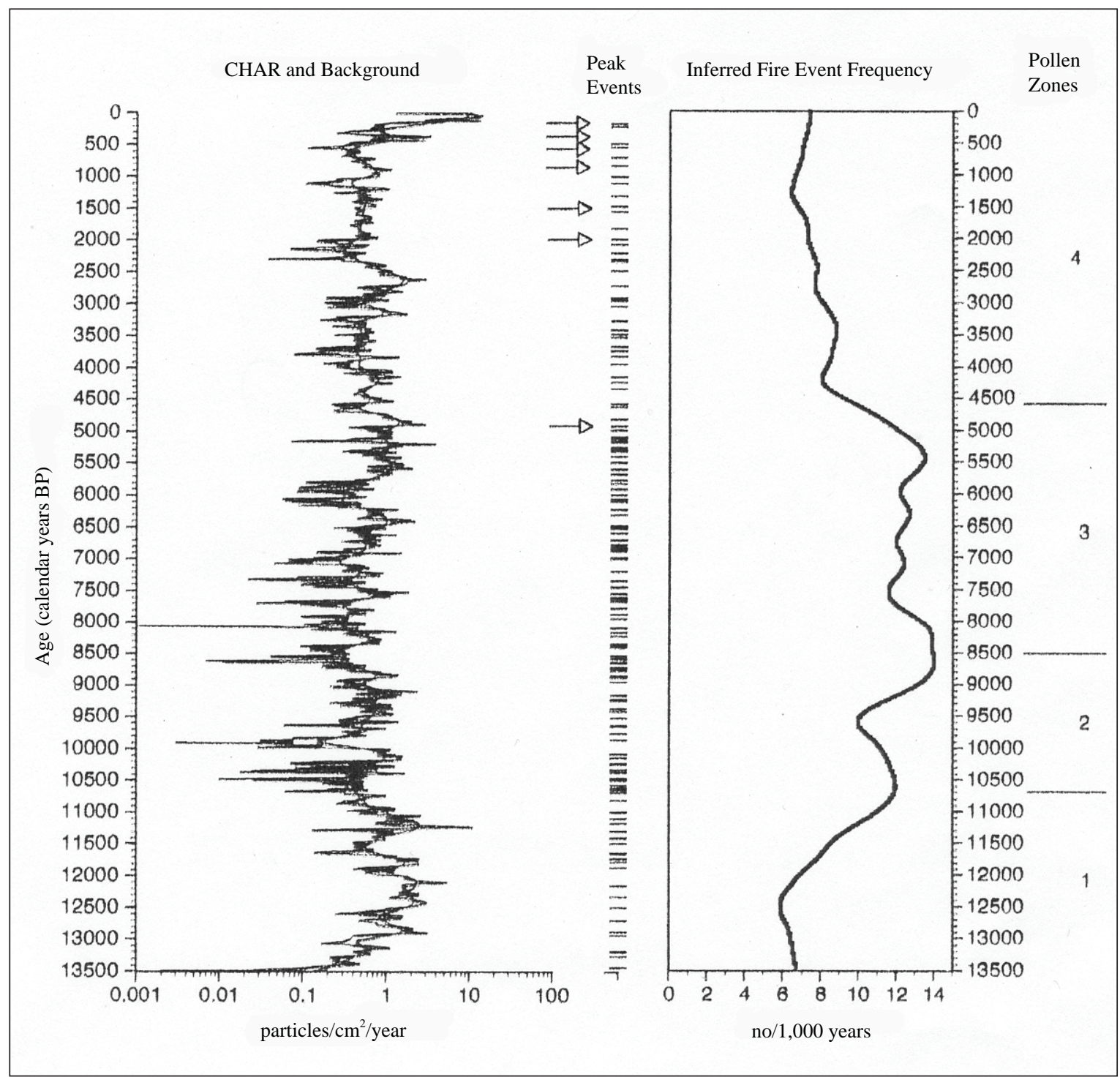

Figure 40. Charcoal accumulation rates (CHAR) (particles $\left./ \mathrm{cm}^{2} / y r\right)$ and inferred wildfire frequency for Paradox Lake cores (Anderson and others, 2006, fig. 9). Arrows show maximum soil-charcoal ages for accumulation peaks (Anderson and others, 2006, fig. 9). 


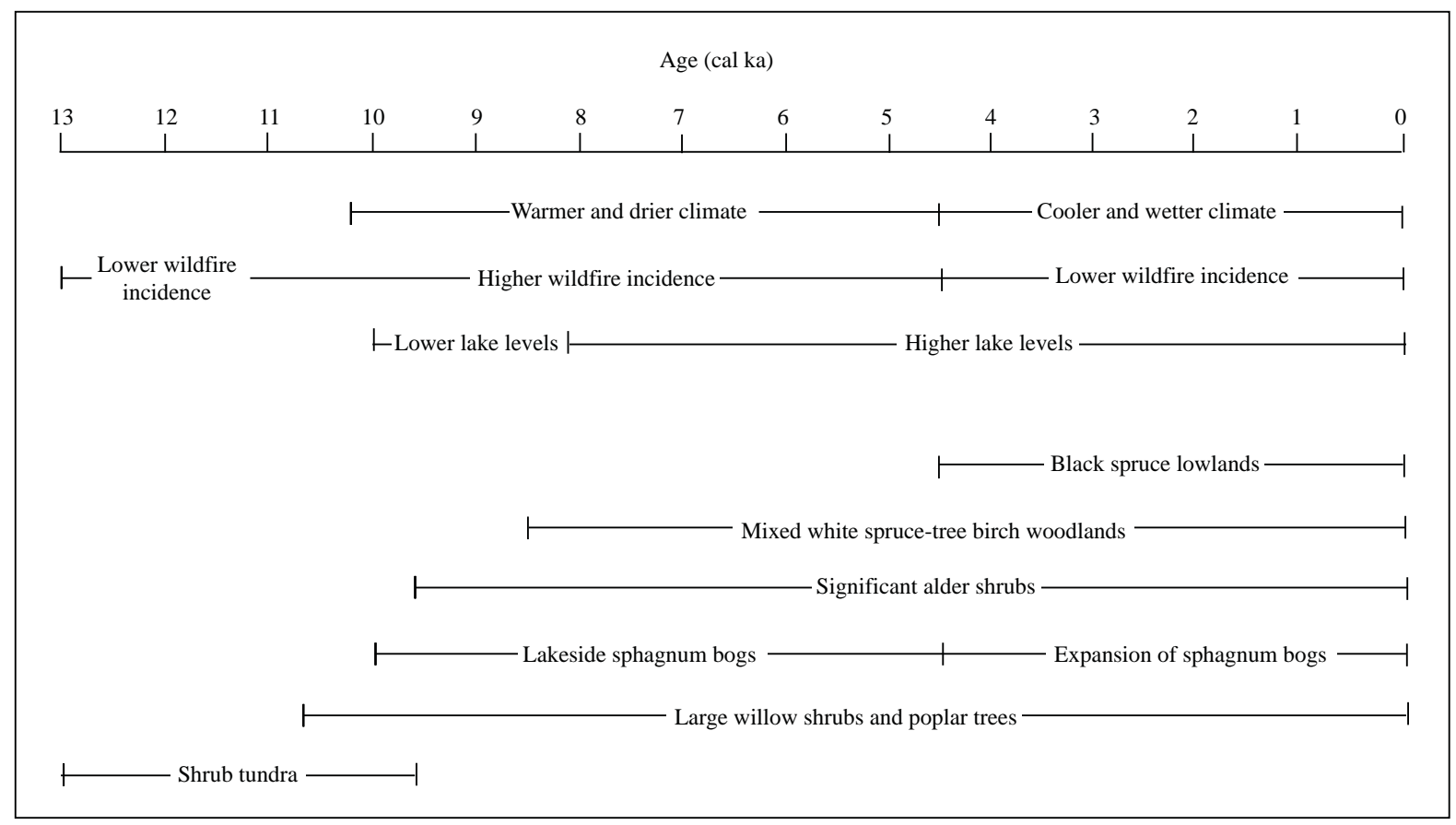

Figure 41. Evolution of climate and vegetation in the Paradox Lake area, nothcentral Kenai Peninsula lowland, summarized from Anderson and others (2006).

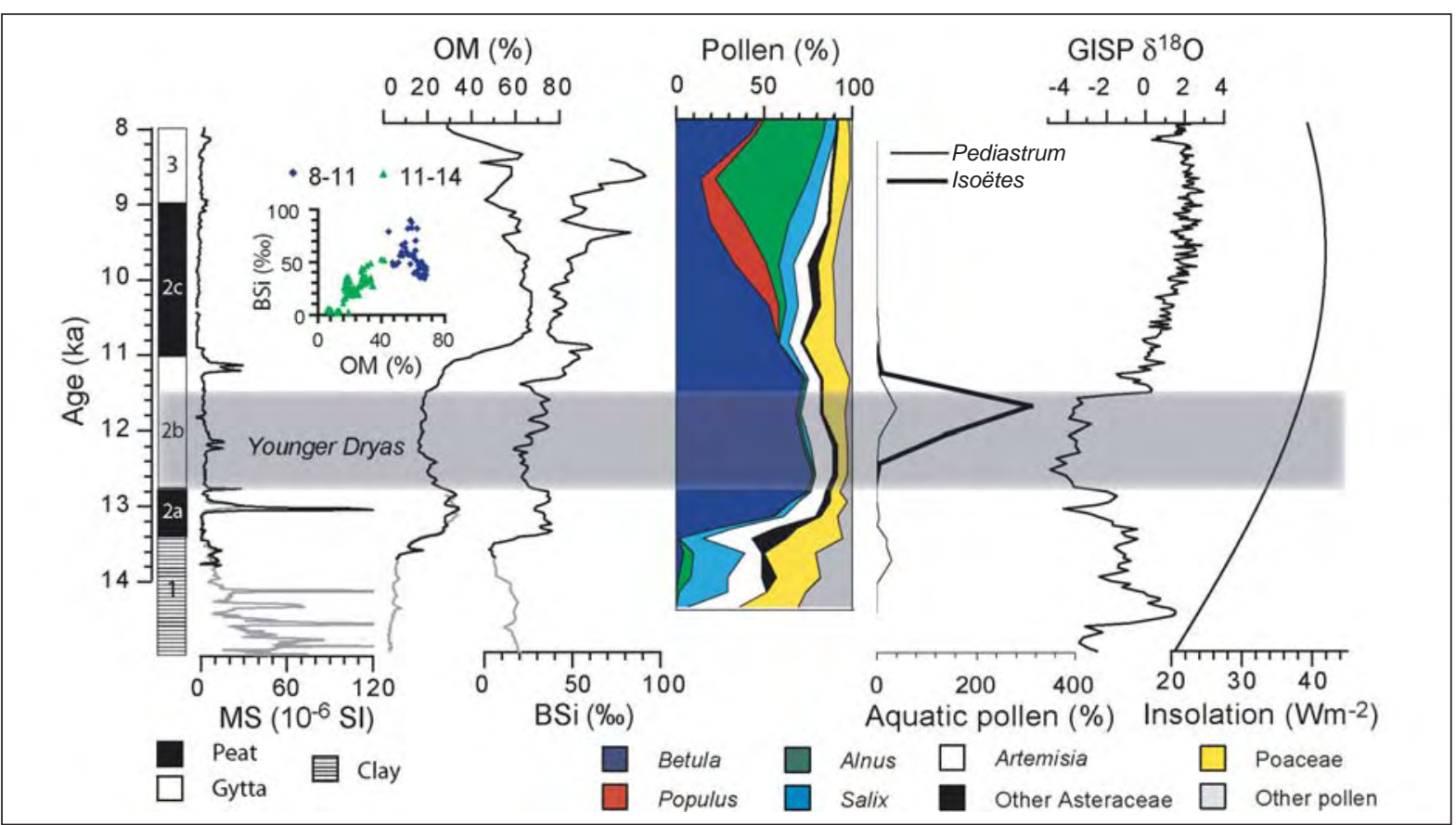

Figure 42. Magnetic susceptibility (MS), loss on ignition (LOI), biogenic silica (BSi), and percentages of major terrestrial pollen types, as well as Pediastrum colonies and Isoëtes spores (measured as percentages of the terrestrial pollen sum) of composite core DP-1/4 from Discovery Pond (Kaufman and others, in preparation, fig. 5). Age in calibrated years $x 10^{3}(\mathrm{ka})$. Gray lines below $13.8 \mathrm{cal}$ kya are based on samples from DP-4, and black lines are based on samples from DP-1. Discovery Pond data are compared with the normalized $\delta^{18} O$ record from Greenland ice core GISP (World Data Center-A for Paleoclimatology, National Geophysical Data Center, Boulder, Colorado). 
as Chironomid and Daphnia remains) become more common after ca. $12.0 \mathrm{cal}$ ka, suggesting a significant change in the local hydrological regime during the late Younger Dryas. Their initial assessment suggests that the late Younger Dryas in north-central Kenai Peninsula lowland may have become wet and cool, in contrast to interior and southwestern Alaska where the Younger Dryas was dry and cold (Hu and others, 1993, 1995). If so, this may reflect a stronger Aleutian Low with greater winter precipitation in northern Kenai Peninsula lowland (Kaufman and others, in preparation). After the Younger Dryas, peat accumulation began again at Discovery Pond with the return of a warmer climate leading to the Holocene thermal maximum at $10.0 \mathrm{cal}$ ka (Kaufman and others, 2004) (fig. 42). Since $9.0 \mathrm{cal} \mathrm{ka,} \mathrm{gyttja} \mathrm{was}$ deposited in Discovery Pond.

\section{SwANSON FEN}

Evidence for climate conditions during the Younger Dryas is expressed differently in a peat core retrieved from Swanson Fen, a small fen close to Discovery Pond at the end of Swanson River Road (fig. 38). According to a pollen and macrofossil study by Miriam Jones (unpublished data), gyttja began accumulating in a shallow pond at Swanson Fen $14.1 \mathrm{cal} \mathrm{ka}$ and changed to a non-moss aquatic peat without gyttja at the beginning of the Younger Dryas, 12.7 cal ka. During the Younger Dryas, birch pollen was abundant, but sedge, grass, and willow pollens were less abundant, and peat was poorly preserved, indicating a drier climate. The arrival of buckbean seeds and a decrease in pondweed seeds during the Younger Dryas imply a shallow water depth, which is consistent with a drier climate (Peteet and others, 2007). The hydrologic evidence [non-sphagnum moss peat (not gyttja) and aquatic plant macrofossils] at both Swanson Fen and Discovery Pond seem to argue that Younger Dryas water levels were not low, but the dry implications of the terrestrial vegetation imply that the higher water table was a result of greater winter precipitation that offset a relatively dry growing season. More sites that document the Younger Dryas need to be examined to clarify the hydrology of this last cold pulse of the Naptowne glaciation.

\section{JigSAW LAKE}

Jigsaw Lake is a 58-ha (143-ac), closed-basin lake located on the drainage divide between Swanson River and Moose River (fig. 38). This lake appears to be very sensitive to climate change. Lake level dropped $>1 \mathrm{~m}(>3 \mathrm{ft})$ during the warm 1990s A.D., and evidence indicates that a forested wave-cut bench $2.4 \mathrm{~m}(8 \mathrm{ft})$ above present lake level was cut during the early Holocene (fig. 43). Strong evidence for an early Holocene warm climate is a 9.5-cal ka-old thin peat in a 4.4-m (14.4-ft) lake-sediment core collected in 2001 A.D. by Darrell Kaufman, Al Werner, and Christian de Fontaine (unpublished data) from $\sim 12 \mathrm{~m}(\sim 40 \mathrm{ft})$ below the modern surface of Jigsaw Lake. This thin peat indicates that lake level was $\sim 12 \mathrm{~m}$ ( $\sim 40 \mathrm{ft}$ ) lower during a brief dry and warm period $~ 9.5$ cal kya. Corroborative evidence of early Holocene lake

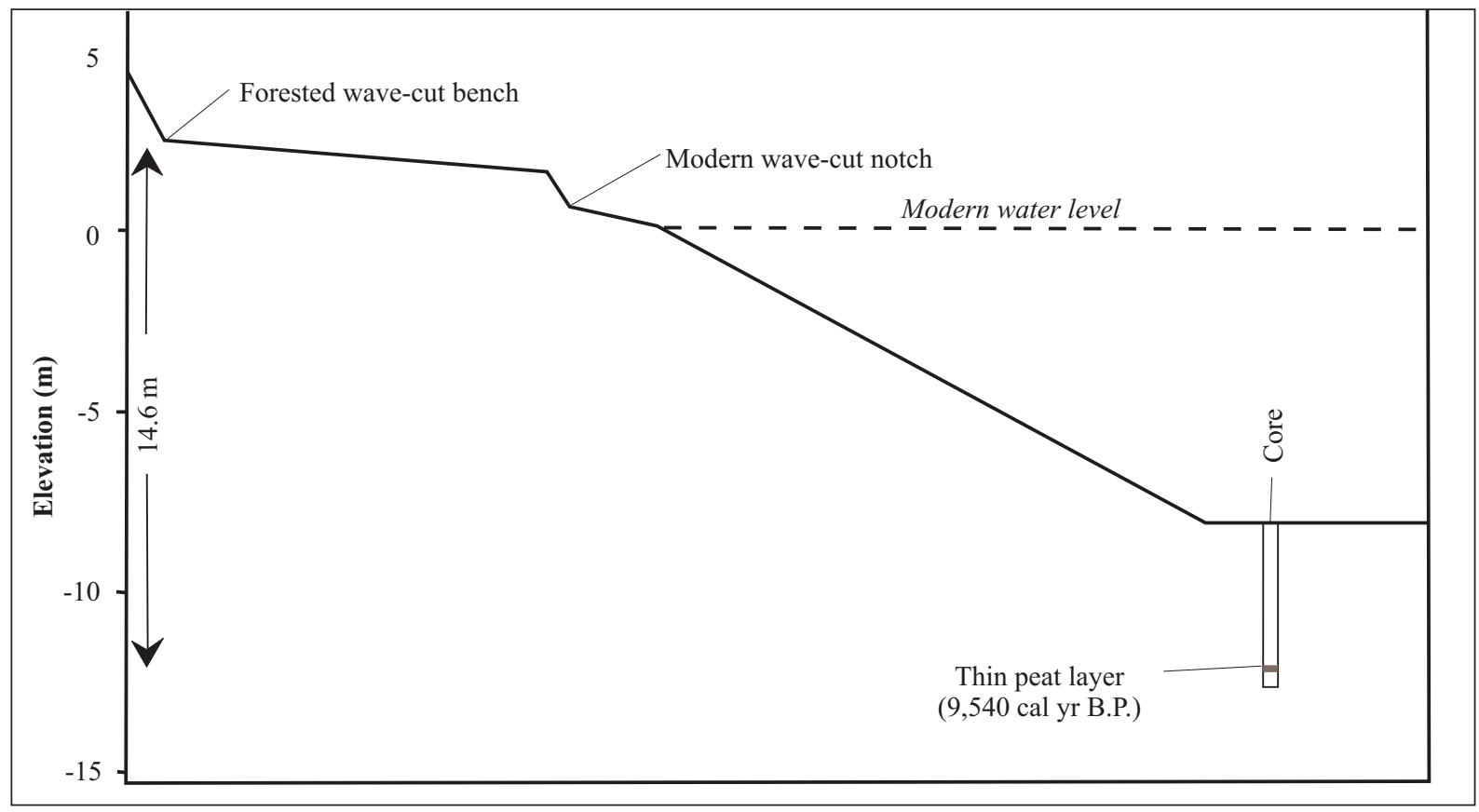

Figure 43. Sketch of Jigsaw Lake profile showing shoreline terraces relative to lake-sediment core collected in 2001 by Darrell Kaufman, Al Werner, and Christian de Fontaine (unpublished data). 
drawdown was also found at Portage and Arrow lakes (fig. 38), where macrofossils are dominantly shallowwater aquatic plants (Nuphar, Potamogeton, and sedges) until $\sim 8.1$ cal kya when the water level rose, and birch seeds and spruce needle macrofossils began accumulating (Anderson and others, 2006).

Evidence that is consistent with a warm, dry climate $\sim 9.5$ cal kya comes from a nearby cove of Jigsaw Lake, where a 3.4-m (11.2-ft) core of sphagnum peat (without lake sediments) has a basal age of $9.6 \mathrm{cal} \mathrm{ka}$, indicating that this cove has not been flooded for $>9.6 \mathrm{cal} \mathrm{ka}$. Except for several undated low-water intervals and a recent lowering of the water table, a profile of inferred depth to water table, based on transfer-function analysis of testate amoebae in the peat core by Edward Mitchell and Keiko Kishaba (unpublished data), indicates a fairly consistent $25 \mathrm{~cm}$ (20.5 in) depth to water table in the accumulating sphagnum moss and peat (fig. 44). Because the cove is hydrologically coupled to Jigsaw Lake, an accumulating peat in which local water table maintains a consistent depth below the moss surface indicates that water level rose no faster in adjoining Jigsaw Lake and the cove was not flooded. These relations and the lack of lake sediments in the cove core also indicate that the 2.4-m (7.9-ft) bench around Jigsaw Lake was cut during a high lake level before 9.6 cal kya, probably during the wet and cool Younger Dryas climate postulated at nearby Discovery Pond. Several interruptions of the consistent rise of water level in the cove may indicate several relatively brief dry periods during the past 9.6 cal ka at Jigsaw Lake. Recent lowering of the water table indicated in the profile is probably a response to recent warm, dry summers when the level of Jigsaw Lake was lower.

MP 83.9, Sterling Highway. Sterling Highway crosses a former alluvial fan built by meltwater drainage from a deeply incised channel parallel to Swanson River Road (sheet 2). This meltwater flowed southward from a prominent late Moosehorn ice limit $6.4 \mathrm{~km}$ ( $\sim \mathrm{mi})$ north of the Sterling Highway and was initially graded to the uppermost terrace of the lower Kenai River terrace set (fig. 35). However, somewhat later in Moosehorn time, this particular drainage changed directions and flowed northeastward $9.6 \mathrm{~km}$ ( $6 \mathrm{mi})$ just inside the Moosehorn terminal moraine and built a pitted delta complex in the vicinity of Grebe Lake (sheet 2).

For the next $4.8 \mathrm{~km}$ ( $3 \mathrm{mi}$ ) we will be driving across an ice-proximal, sandy outwash complex that is derived from recessional ice positions of middle to late Moosehorn age 0.8 to $8.8 \mathrm{~km}$ ( 0.5 to $5.5 \mathrm{mi})$ north of the Sterling Highway (sheet 2).

MP 84.7, Sterling Highway. West end of Scout Lake Loop Road. The lowland ice sheet from northern sources reached its maximum extent south of Scout Lake

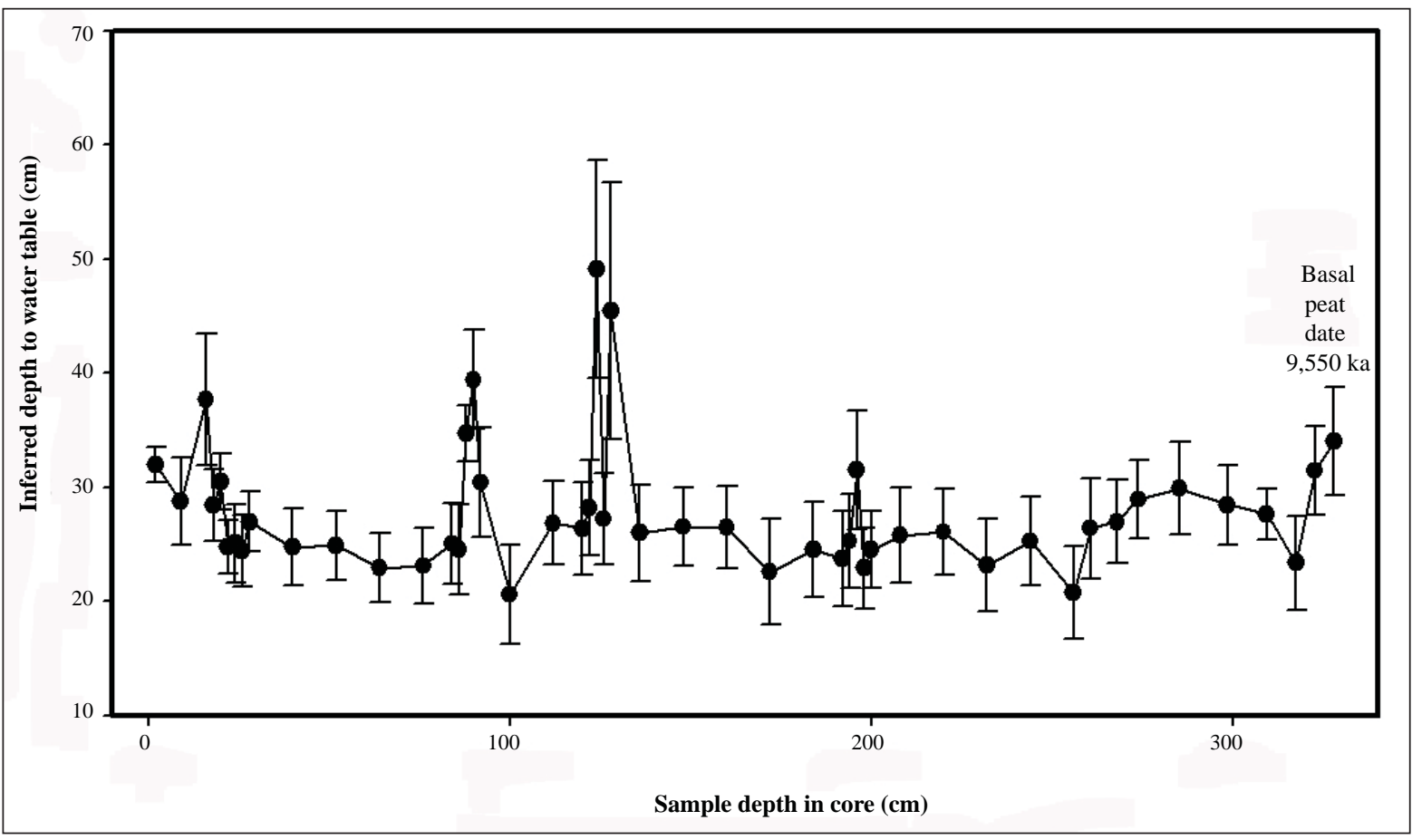

Figure 44. Profile of inferred depth to water table based on transfer-function analysis of testate amoebae in peat core collected in cove of Jigsaw Lake (Edward Mitchell and Keiko Kishaba, unpublished data). 
$\sim 23$ cal kya (fig. 45A). As a consequence of the subsequent climatic warming, the ice sheet began to thin and the glacier margin began a gradual northward recession in early post-climax to middle Moosehorn time. During this phase, a complex of meltwater streams, which was graded to the highest post-diversion floodplain of the braided Kenai River, flowed southward from the glacier margins and buried large masses of stagnant glacial ice in sandy outwash in the vicinity of modern Scout Lake (fig. 45B). Somewhat later, in middle to late Moosehorn time, brief stillstands or readvances produced obvious ice limits north of Sterling Highway (sheet 2), indicating that at least part of the eastcentral lowland ice sheet continued actively flowing and did not stagnate en masse. By this time, buried ice masses in the Scout Lake area had partially melted, producing a complex of kettles in the sandy outwash complex, including the large basin now occupied by Scout Lake (fig. 45C). In the meantime, the early post-diversion valley of the lower Kenai River was starting to form to the south as the river began cutting into the underlying Moosehorn drift. Excavation of the deeply incised valley of the lower Kenai River was completed before a cycle of aggradation began during the Killey stade. Following the Moosehorn stade, peat began filling kettles in the sandy outwash complex where and when water tables were sufficiently shallow (fig. 45D).

MP 87.4, Sterling Highway. Ascending across the western margin of the pitted sandy outwash apron complex, we enter Moosehorn-age drift derived from northern sources, which we will traverse for the next 11 $\mathrm{km}(6.9 \mathrm{mi})$ toward Stop 5 in Soldotna (sheets 2 and 3). Along the Sterling Highway we will see numerous large granitic erratics that probably originated in the Talkeetna Mountains and the Susitna River drainage basin.

MP 87.6, Sterling Highway. West end of Robinson Loop Road. Lethe tephra is present near the base of 0.7-m- (2.3-ft-) thick loess overlying early to middle Moosehorn ice-stagnation sediments in this area (Reger and others, 1996, fig. A38).

A MP 88.1, Sterling Highway. Whisper Lake and nearby Longmere Lake (MP 88.6) are two of many large kettle lakes in sandy ice-stagnation sediments of early to middle Moosehorn age in this part of the northcentral Kenai Peninsula lowland (sheet 2). Sand dunes $0.3 \mathrm{~km}$ (0.2 mi) northwest of Whisper Lake are derived from local sandy glaciogenic deposits, and contain Lethe tephra, indicating that the dunes were active late in the Killey stade (Reger and others, 1996, fig. A28).

A 3.3-m (10.8-ft) core collected from Longmere Lake and analyzed by Tom Ager reinforces models of vegetation evolution during the past $10.4+\mathrm{RC} \mathrm{ka}(12.2+\mathrm{cal} \mathrm{ka})$ proposed for the northern Kenai Peninsula lowland (Ager and Sims, 1981; Ager, 1983; Ager and Brubaker, 1985; Ager and others, 1985; Anderson and others, 2006; Peteet and others, 2007; Kaufman and others, in preparation), but pollen zones in the Longmere Lake core are not tightly constrained by radiocarbon dating. A bulk-sample of lake sediments from a core interval of 9.5-10.1 ft (289-309 cm), which samples a shrub-herb pollen zone, dates $10,400 \pm 300$ RC yr B.P. (W-5,527) $(12,186 \pm 300 \mathrm{cal}$ yr B.P.) (T. Ager, unpublished data). Pollen and spore counts of lake sediments from this early interval indicate that shrub birch, sedges, grasses, and Artemisia were common on surrounding slopes, and late in the shrub-herb zone, ferns (Polypodiaceae) and Equisetum became widespread. At that time, considerable water lily (Nuphar) was rooted in the lake, indicating that the lake was shallower than today. The birch shrub-herb pollen zone was followed successively up the core by a pollen/spore zone dominated by willow and alder shrubs, poplar trees, and ferns and a higher pollen/spore zone recording the spread of alders and the introduction of birch trees, with fern spores declining. Evidence that the birch-alder zone ended $\sim 8.0 \mathrm{RC}$ ka ( $\sim 9.0 \mathrm{cal} \mathrm{ka}$ ) is provided by a bulk-sediment sample from core interval 233-248 cm (7.6-8.1 ft), which dated 7,880 \pm 250 RC yr B.P. (W-5,494) $(8,764 \pm 250 \mathrm{cal}$ yr B.P. $)$ (T. Ager, unpublished data), shortly after an increase of spruce pollen in the core. Thus, this sample also places the spread of spruce into this part of the northcentral Kenai Peninsula lowland at $\sim 8.0$ RC kya ( 9.0 cal kya). For the past 7.9 RC ka (8.8 cal ka), the pollen rain into Longmere Lake has been dominated fairly consistently by birch and spruce trees and by alder shrubs, all of which are common in the area today.

AP 89.3, Sterling Highway. The Sterling Highway crosses the first of two meltwater channels originating at the former glacier limit of middle to late Moosehorn age $1.1 \mathrm{~km}(0.7 \mathrm{mi})$ north of the highway and graded to the lower Kenai River as it existed at that time (sheet 2). We cross the second channel at MP 89.8.

MP 92.6, Sterling Highway. Crossing of the deeply incised lower valley of underfit Soldotna Creek (sheets 3 and 4). This meltwater drainage system can be traced 8.5 and $13.9 \mathrm{~km}$ (5.3 and $8.7 \mathrm{mi}$ ) upstream to two late Moosehorn ice limits. Outwash gravel carried by late Moosehorn proglacial streams is preserved in terrace fills overlying Moosehorn drift at $\sim 45 \mathrm{~m}(\sim 150 \mathrm{ft})$ elevation on both sides of Soldotna Creek (fig. 46), 25 m ( 80 ft) above the level of the lower Kenai River today. With the retreat of glacial ice from the area, Soldotna Creek cut downward to keep pace with the lower Kenai River as it excavated its much larger valley, and the terrace remnants document the level of lower Kenai River in late 


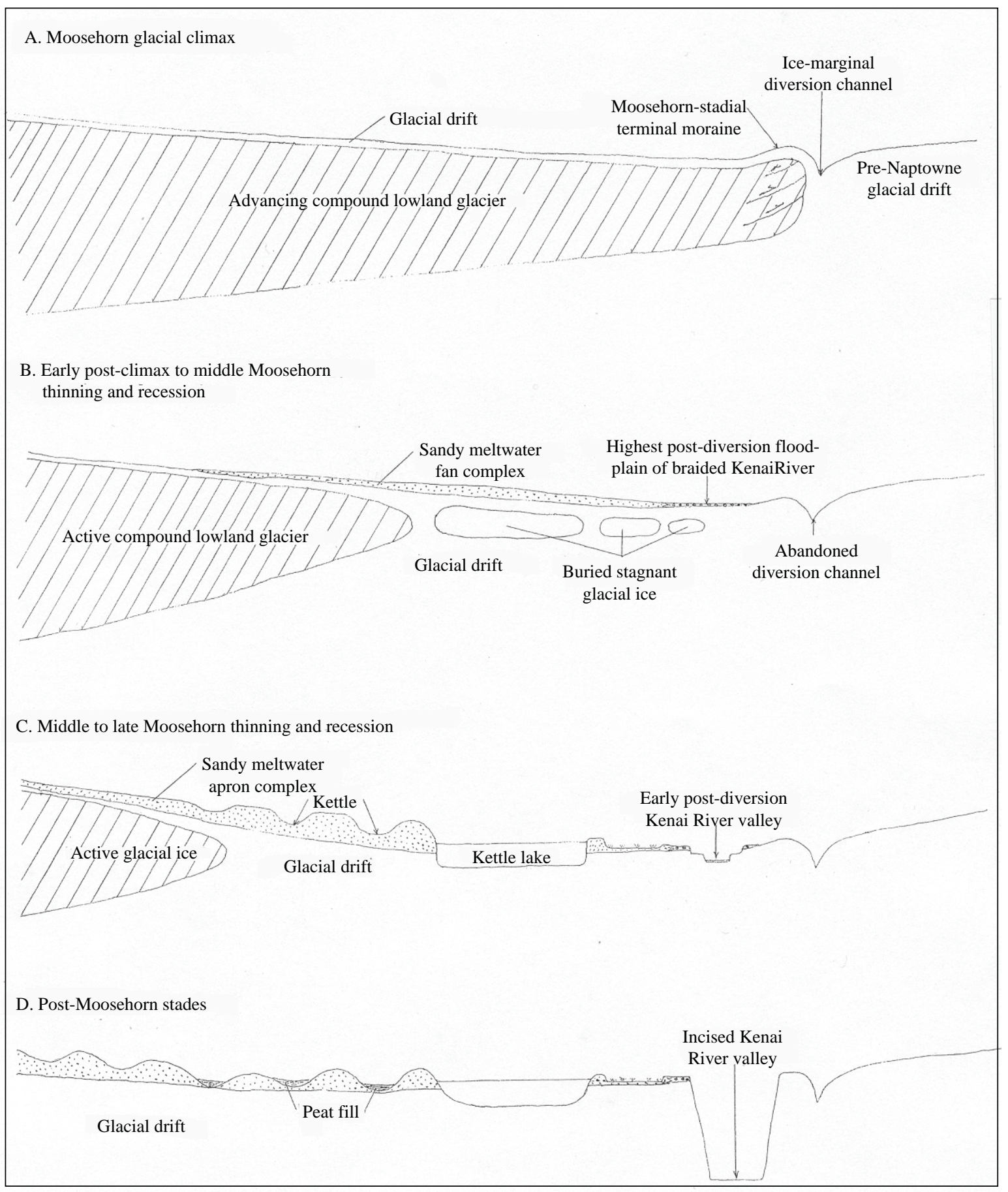

Figure 45. Evolution of sandy meltwater complex in vicinity of Scout Lake, northcentral Kenai Peninsula lowland. 
Moosehorn time. The flat floor of Soldotna Creek valley is Killey in age and grades $0.3 \mathrm{~km}(0.2 \mathrm{mi})$ downstream of the highway crossing to the upper (Sterling) terrace of the lower Kenai River (sheet 3).

In the Mackeys Lakes area to the north, former ice-marginal meltwater lakes followed the receding ice front northward during middle to late Moosehorn time, leaving clay-rich and sandy lake-bottom sediments beneath the lowlands and on the flanks of a local esker complex (fig. 47). Wave action in these lakes subdued the submerged morainal topography in contrast to the relatively high-relief, lake-pocked topography of moraines that were not submerged beneath lake waters farther north (sheet 4).

MP 93.4, Sterling Highway. Begin descent into the deeply incised valley of the lower Kenai River. The lower half of this hill crosses the upper body of a landslide, now highly altered by construction, which flowed southward from the unstable, steep wall of the valley during or after the late Moosehorn stade and
Moosehorn-Killey interstade when deep valley incision occurred (R.D. Reger, 2004). The terminal bulge of this large flow is visible behind the Fred Meyer building south of the Sterling Highway. An even larger landslide, which exhibits open tension cracks and therefore is probably still active, is located on the south wall of the lower Kenai River valley $7.5 \mathrm{~km}$ (4.7 mi) east of this failure (sheet 2).

A 94.1, Sterling Highway. Junction of Sterling Highway and Kenai Spur Highway. This junction is located at the highly modified scarp separating the two terraces upon which Soldotna is sited. The higher surface, which underlies most of the community, is underlain by 5-15 m (16-49 ft) of outwash gravel above diamicton of Moosehorn age (Anderson, 1972; Anderson and Jones, 1972, section S-S'). Lethe tephra was found near the base of loess on the tread of the upper terrace near this junction (Reger and others, 1996, fig. A46), and Lethelike tephras (not yet confirmed by electron-microprobe analyses) have subsequently been found at several other

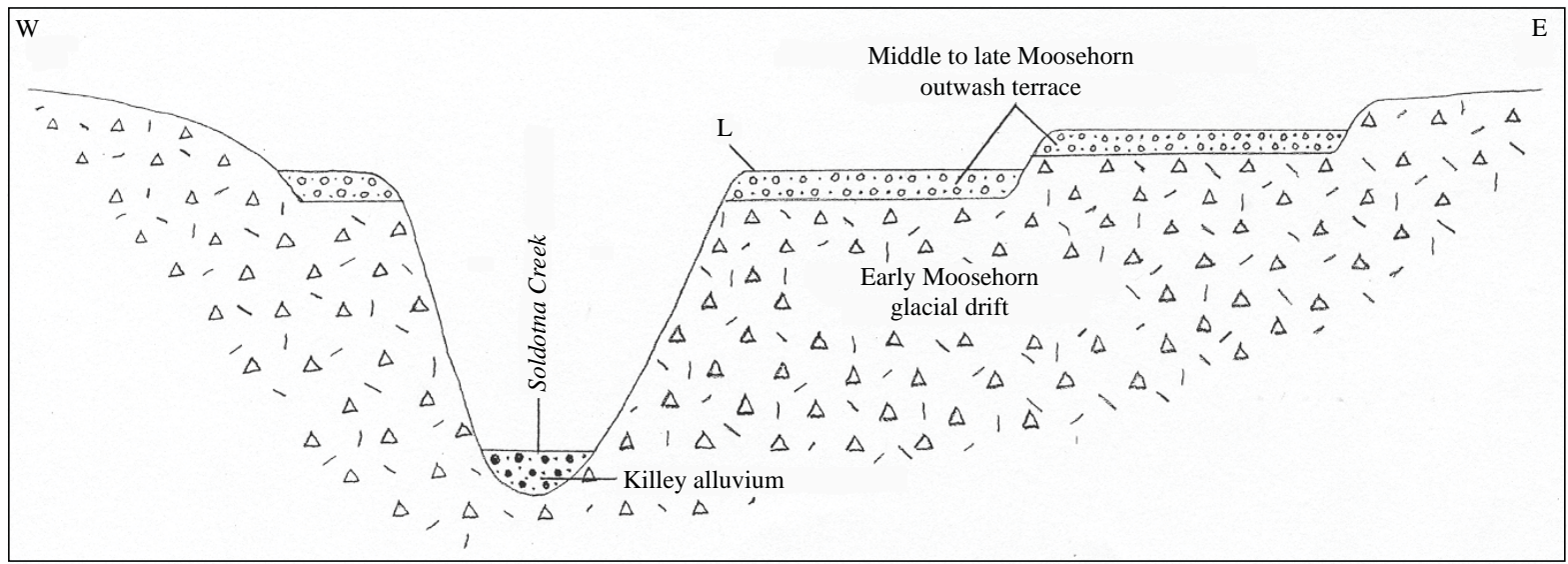

Figure 46. Sketch of physiography and geology at crossing of Soldotna Creek by Sterling Highway. L = Lethe tephra.

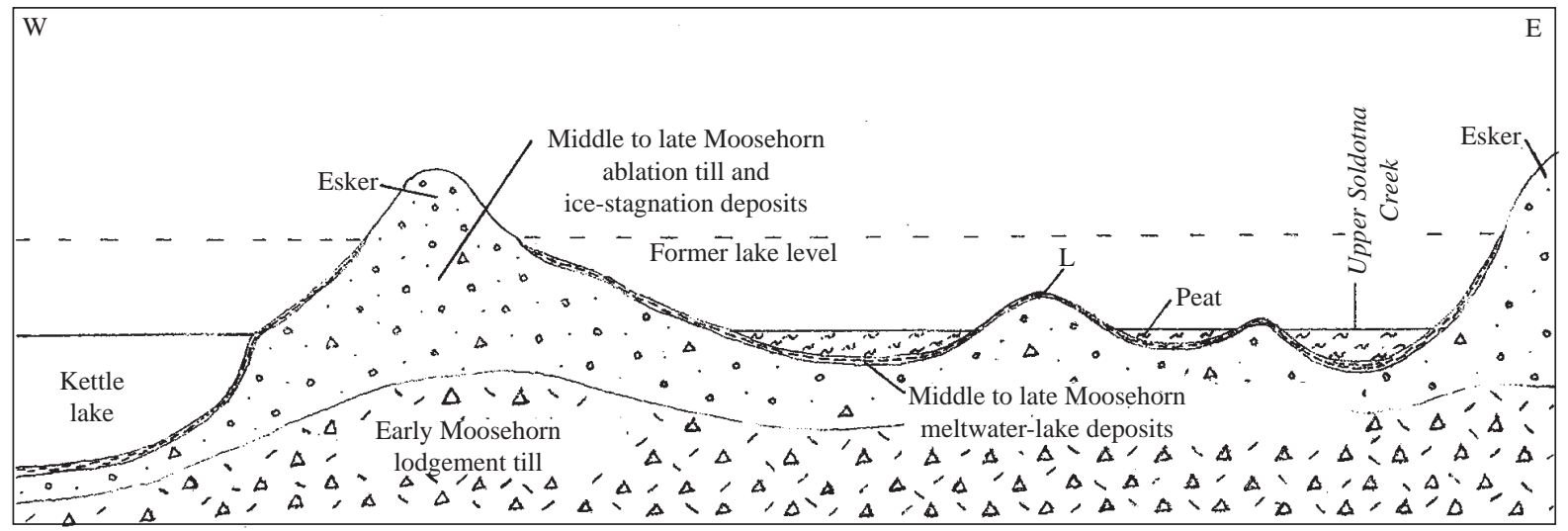

Figure 47. Sketch of physiography and geology of middle to late Moosehorn deposits in vicinity of Mackeys Lakes, westcentral Kenai Peninsula lowland (sheet 4). $\mathbf{L}=$ Lethe tephra. 
locations on the upper terrace, supporting correlation of the upper terrace with the Sterling Terrace of Killey age. The lower terrace at Soldotna, which is crossed by the Sterling Highway for the next $1.8 \mathrm{~km}(1.1 \mathrm{mi})$, is informally called the Soldotna Terrace. Lethe tephra has not been found on the Soldotna Terrace (Riehle and others, 2006, fig. 14), which grades discontinuously upriver to the type Skilak terminal moraine, suggesting but not proving that the terrace is Skilak in age (fig. 35) (R.D. Reger, 2004). The 5-m- (16-ft-) thick gravel fill comprising the tread of the Soldotna Terrace is generally underlain by clayey diamicton of Moosehorn age.

Continue southwest on Sterling Highway.

MP 94.6, Sterling Highway. Junction of Sterling Highway and South Binkley Street (to the right), which ascends the 3- to 5-m- (10- to 16-ft-) high scarp between the upper Sterling Terrace and the lower Soldotna Terrace to the north (sheet 3 ).

MP 95.2, Sterling Highway. Crossing of David Douthit Veterans Memorial Bridge over the lower Kenai River, which drains $\sim 5,070 \mathrm{~km}^{2}\left(\sim 1,950 \mathrm{mi}^{2}\right)$ of the western Kenai Peninsula (Curran and others, 2003). Consistently high summer flows are maintained in the lower Kenai River by seasonal rainfall, groundwater contributions, and meltwater from $546 \mathrm{~km}^{2}\left(\sim 210 \mathrm{mi}^{2}\right)$ of snowfields and glaciers in the Kenai Mountains
(Scott, 1982). Serious flooding occurs every 2 to 4 yrs in response to outbursts from glacier-impounded lakes in the headwaters of Kenai River and when massive ice jams block the lower Kenai River $11 \mathrm{~km}$ ( $\sim \mathrm{mi})$ downstream from this bridge (U.S. Army Corps of Engineers, 1967, 1973, 1975; Post and Mayo, 1971; Scott, 1982). Outburst flooding is particularly destructive when glacier-dammed lakes drain during winter, as happened when a lake beneath Skilak Glacier suddenly drained in mid-January this year (2007 A.D.), raising local river

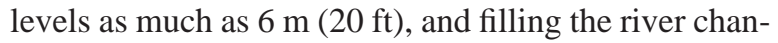
nel with huge ice jams that slowly moved downstream, causing $\sim$ \$3 million damage to riverbank structures.

\section{STOP 5. SOLDOTNA}

MP 95.3, Sterling Highway. Turn right (northwest) into the parking lot of the Kenai Peninsula Visitor Information Center.

We are standing at the edge of the Sterling Terrace on the southwest side of the lower Kenai River, and we can look northeast across the river at the Sterling Highway crossing the lower Soldotna Terrace to the bridge. We are $\sim 50-55 \mathrm{~m}(\sim 165-180 \mathrm{ft})$ below the level of the surrounding uplands, which are widely notched by former channels of the diverted ancestral Kenai River southeast of Soldotna at elevations of 85 and $65 \mathrm{~m}$ (280 and $213 \mathrm{ft}$ ) (channels $\boldsymbol{B}$ and $\boldsymbol{C}$ in fig. 34) (sheet 3). This valley is

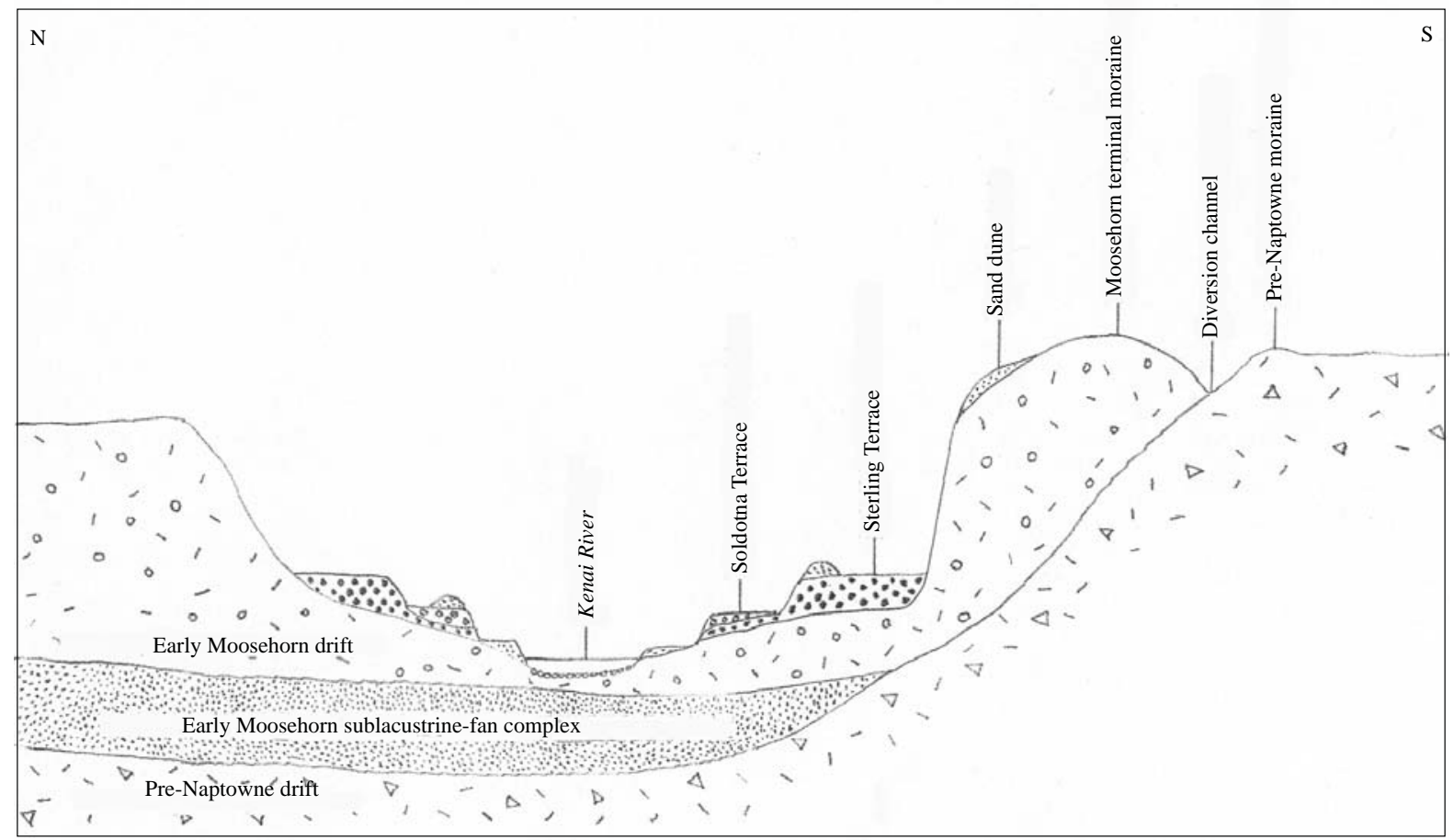

Figure 48. Sketch across valley of lower Kenai River in Soldotna area, showing general physiographic and geologic relations. 
deeply eroded into drift of Moosehorn age (fig. 48), and the oldest exposed deposit on the valley floor is the Killey-age Sterling Terrace, upon which we are standing, indicating that the vast bulk of the material removed to form the lower Kenai River valley was removed between the Moosehorn climax and the Killey stade. Evidence in the lower Soldotna Creek area indicates that the lower Kenai River was $\sim 25 \mathrm{~m}(\sim 80 \mathrm{ft})$ above its present level in late Moosehorn time (fig. 46), so some erosion was already occurring during the late Moosehorn stade. Eventually $\sim 70 \mathrm{~m}(\sim 230 \mathrm{ft})$ of downcutting occurred in the Soldotna area during that initial erosion phase (table 3).

The Killey advance of the Skilak Lake, Killey, and Funny River lobes flushed enough rock debris into the lower Kenai River to accumulate $\sim 6 \mathrm{~m}(\sim 20 \mathrm{ft})$ of gravel fill in the Soldotna area and form the Sterling Terrace. Investigations in local gravel pits indicate that the lower Kenai River was braided and channel changes were frequent during the Killey stade. The Sterling Terrace and lower Kenai River valley broaden suddenly at Soldotna, marking the apex of an extensive braid delta (McPherson and others, 1987) of Killey age that spread from the Soldotna area north and northwest into glacioestuarine ancestral Cook Inlet in the vicinity of Kenai. We will traverse this surface as we drive toward Kenai.

Between the Killey and Skilak stades, the lower Kenai River removed $\sim 5 \mathrm{~m}(\sim 16 \mathrm{ft})$ of gravel in the Soldotna reach (table 3), and the river may not have been braided. Subsequent readvances of the Skilak Lake, Killey, and Funny River lobes (sheet 2) during the Skilak stade introduced another pulse of rock debris into the lower Kenai River, and $\sim 2 \mathrm{~m}(\sim 6.5 \mathrm{ft})$ of gravel fill built up in the Soldotna area to form the Soldotna Terrace. Deposits of the Soldotna Terrace indicate that the river was braided at that time. Winds blowing across bare bars of the braided floodplain picked up sand and silt and deposited them nearby. Rapidly shifting braidedchannel networks with diurnally fluctuating levels of sediment-charged water quickly replaced deflated sand and silt, perpetuating floodplain surfaces as sources of sand and loess. Sand dunes deposited on the Sterling Terrace during the Skilak stade are covered by Holocene loess and do not contain Lethe tephra. Scarp-top dunes derived from bare river bars and from unvegetated bluff faces, but now stabilized and covered by tall spruce trees, form a dune belt along the edge of the Sterling Terrace east and west of this locality (R.D. Reger, 2004). Small dune fields are piled against the base of the high valley wall south of Soldotna.

With the withdrawal of the Skilak Lake lobe from the inner end moraine of Skilak age, the primary source of rock debris fed into the lower Kenai River was cut off, and the river began a period of sustained erosion that was briefly interrupted when local sources of material became available (table 3) (R.D. Reger, 2004). In the vicinity of Soldotna, the lower Kenai River removed as much as $16 \mathrm{ft}$ (5 m) of material, locally exposing the underlying Moosehorn drift and armoring the river channel with a lag of erratic boulders and blocks liberated from the Moosehorn till (fig. 49). Foundation borings for the lower Kenai River bridge here at Soldotna indicate that $\sim 6 \mathrm{~m}(\sim 20 \mathrm{ft})$ of Moosehorn drift remain between the bed of the river and the underlying sandy glaciolacustrine fan complex that is the primary confined aquifer for the many artesian wells in the Soldotna area (Anderson, 1972; Anderson and Jones, 1972). The presence of this sandy sublacustrine unit indicates that advancing early Moosehorn ice floated or at least partially floated in an extensive meltwater lake.

Table 3. Changes in Soldotna reach of lower Kenai River during and after Naptowne glaciation

\begin{tabular}{|c|c|c|c|}
\hline Chronological unit & Age (kya) & Major river activity & Net change (m) \\
\hline Post-Skilak time & Last $\sim 16.5$ & Cut and minor fill & $\begin{array}{c}-5 \\
\text { Channel armoring }\end{array}$ \\
\hline Skilak stade & $\sim 16.5-\sim 17.5$ & Fill & +2 \\
\hline Brief interstade & ? & Cut & -5 \\
\hline Killey stade & $\sim 17.5-\sim 18.5$ & Fill & +6 \\
\hline $\begin{array}{l}\text { Brief interstade } \\
\text { and late } \\
\text { Moosehorn stade }\end{array}$ & $\sim 18.5-\sim 19.5$ & Cut & -70 \\
\hline $\begin{array}{l}\text { Early and middle } \\
\text { Moosehorn stade }\end{array}$ & $\begin{array}{c}\sim 19.5 \\
\sim 19.5 \sim 23 \\
\sim 23-\sim 28\end{array}$ & $\begin{array}{l}\text { Establish modern course } \\
\text { Lower Kenai River diversion } \\
\text { Pre-diversion river course }\end{array}$ & $\begin{array}{l}\text { Derangement } \\
\text { of previous } \\
\text { drainage }\end{array}$ \\
\hline
\end{tabular}


Leaving the parking lot, we turn right (southwest) and proceed $0.2 \mathrm{~km}(0.1 \mathrm{mi})$ to the junction of the Sterling Highway and Kalifornsky Beach Road before bearing right and driving west on Kalifornsky Beach Road, which is named after a small, abandoned former Denaina village $3.2 \mathrm{~km}(\sim 2 \mathrm{mi})$ north of the mouth of the Kasilof River (sheet 3) (Kari, 1983). For the initial $1.1 \mathrm{~km}(0.7 \mathrm{mi})$ we drive on the Sterling Terrace through low sand dunes of Skilak age. Numerous excavations in these stabilized dunes have not exposed Lethe tephra.

A MP 20.3, Kalifornsky Beach Road. ${ }^{9}$ Crossing of underfit Slikok Creek, which flows northward across an extensive, gently sloping, sandy alluvial fan on the Sterling Terrace (sheet 3). Lethe tephra was found near the eastern limit of this fan (Reger and others, 1996, fig. A51), indicating that the fan is late Killey in age or older.

Slikok Creek has an interesting and complicated history. About $6.4 \mathrm{~km}$ (4 mi) upstream of this crossing and $1.3 \mathrm{~km}(0.8 \mathrm{mi})$ south-southeast of the crossing of Slikok Creek by the Sterling Highway (MP 99.4), this small underfit stream takes an abrupt change of direction and, leaving the former channel of the diverted ancestral Kenai River, flows northwest (fig. 50) (sheet 3). Cross-bedding and imbrications in cobbly pebble gravel overlying Moosehorn till in the highest terrace south of the highway crossing demonstrate that ancestral Slikok Creek initially flowed south-southeast, opposite its present flow direction, when those terrace gravels were deposited. The terrace gravels contain exotic lithologies, like agates, volcanics, pebble conglomerate with limestone clasts, baked siltstone, and granitics, that clearly came from the west side of Cook Inlet and were obviously brought to this locality by Moosehorn ice

\footnotetext{
${ }^{9}$ Mileposts along Kalifornsky Beach Road are referenced from the southern junction of the Sterling Highway and Kalifornsky Beach Road at Kasilof, MP 0 (sheet 3).
}

(fig. 51A). When the gravels were deposited in early to middle Moosehorn time, ancestral Slikok Creek carried meltwater and these exotic lithologies south-southeastward from the nearby ice sheet into the diversion channel of the ancestral Kenai River (fig. 51B). However, we know from evidence southeast of Soldotna that the early to middle Moosehorn stade was a time of transition after the climax of the Moosehorn advance when the lowland ice sheet thinned and receded. Consequently, the volume of meltwater flowing in the former diversion channel declined through early to middle Moosehorn time, as the northern meltwater source disappeared, and ancestral Slikok Creek became nonglacial in character (fig. 51C). We speculate that the gradient of the valley of lower Slikok Creek gradually declined, as ice from northwestern sources thinned and receded, and eventually reversed in direction so that a greatly diminished, nonglacial lower Slikok Creek began flowing north-northwestward. Sand to form the Slikok Creek fan crossed by Kalifornsky Beach Road on the Sterling Terrace (fig. 51D) probably came from local slopes and valley walls or was reworked from eolian deposits southwest of the diversion elbow, where local sand dunes were derived from sandy ice-stagnation deposits of the Moosehorn moraine complex (sheet 3).

MP 19.1, Kalifornsky Beach Road. Here, at the crossing of Poppy Lane at an elevation of $\sim 25 \mathrm{~m}$ ( $\sim 80 \mathrm{ft}$ ), is the approximate transition from the glaciofluvial-dominated part of Sterling Terrace to the braid delta zone of Sterling Terrace, which interfingers with deposits of the Kalifornsky Glacioestuarine Terrace (sheet 3). Excavations indicate that the outer fringe of the Slikok Creek fan was built into glacioestuarine waters of ancestral Cook Inlet during the Killey stade (Reger and others, 1996, fig. A45), and sand dominates upper sections exposed in gravel pits in the braid delta north of Poppy Lane (R.D. Reger, unpublished data).

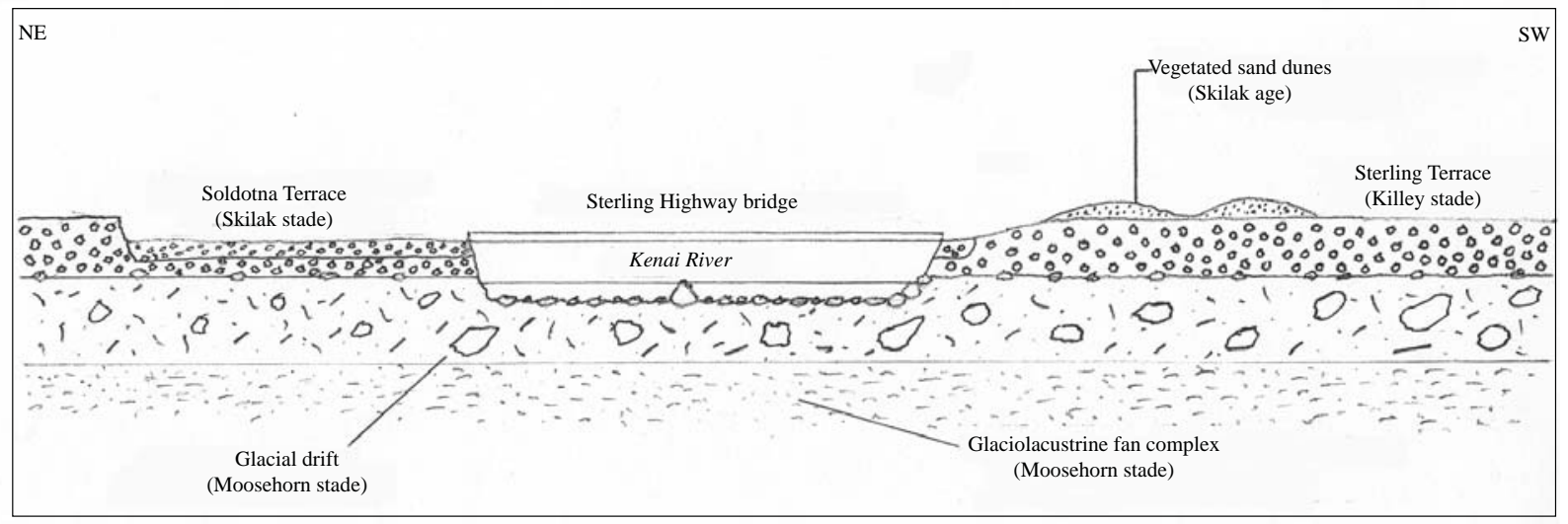

Figure 49. Sketch of physiographic and stratigraphic relations in vicinity of Sterling Highway bridge in Soldotna. 


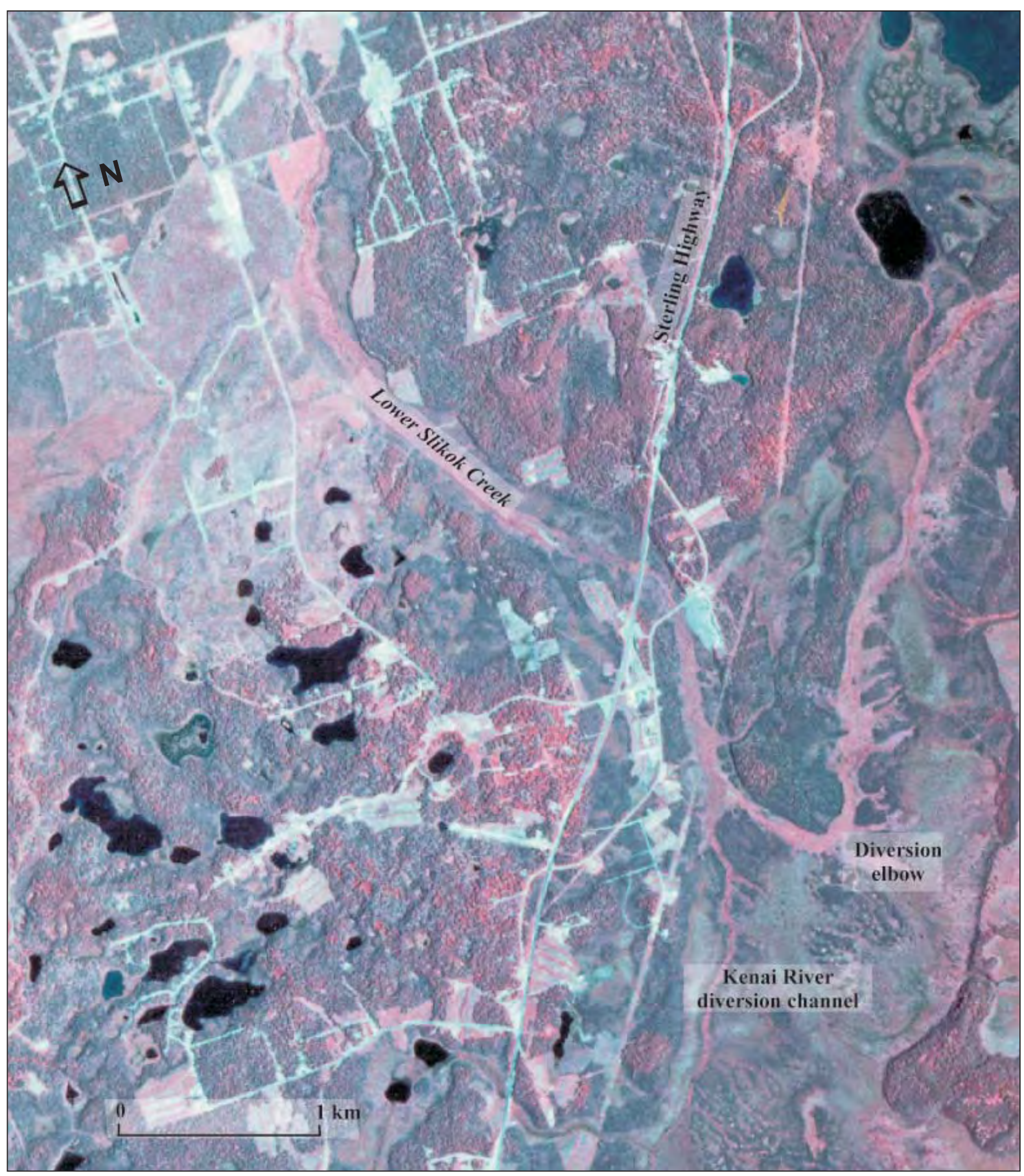

Figure 50. False-color, infrared aerial photograph showing lower Slikok Creek in vicinity of diversion elbow near Sterling Highway. 
MP 17.1, Kalifornsky Beach Road. We descend from the Sterling Terrace down onto the tread of an intermediate terrace at $\sim 20 \mathrm{~m}(\sim 65 \mathrm{ft})$ elevation (sheet 3). During the KilleySkilak interstade, the lower Kenai River removed $\sim 6 \mathrm{~m}(\sim 20 \mathrm{ft})$ of fluvial sandy gravels of Killey age and underlying icestagnation deposits of late Moosehorn age and deposited $\sim 1-2 \mathrm{~m}(\sim 3-7 \mathrm{ft})$ of sandy pebble gravel to form this surface (R.D. Reger, 2004, fig. 6).

AP 16.4, Kalifornsky Beach Road. Junction with Bridge Access Road. Turn right (north) and proceed on Bridge Access Road.

A MP 0.1, Bridge Access Road. ${ }^{10}$ Descend onto the marshy lowest terrace of the lower Kenai River, which is underlain by estuarine sediments. A section across the valley of the lower Kenai River reveals the complex nature of the geology here (fig. 52). Remnants of terraces are preserved along the valley walls as evidence of complex cycles of deposition and erosion during late Naptowne stades and interstades. These cycles record responses of complex fluvial systems to climatic changes. Also preserved is a record of the complex interactions of land- and sea-level changes, which we will discuss in more detail at Stop 7. For the moment, we want to note that the modern zone of tidal influence extends up the lower Kenai River to river mile 12 (sheet 4), and that estuarine deposition began in the lower Kenai River estuary between 8.0 and $9.0 \mathrm{cal}$ kya, when rising postglacial eustatic sea level finally caught up with the slowing rebound of the isostatically depressed lowland in this area (R.D. Reger, 2004).

The thin white tephra cropping out of the peat in the south bank of the lower Kenai River at Warren Ames Memorial Bridge probably correlates with the Hayes tephra and was deposited here by an east- to southeastmoving ash plume from Hayes Volcano 3.6 RC ka ( 4.0 cal ka) (Riehle, 1985; Riehle and others, 1990;

\footnotetext{
${ }^{10}$ Unfortunately, Bridge Access Road is not shown on the base map (sheet 4), nor are there any mileposts, so we informally reference our route mileage on Bridge Access Road from the junction of Kalifornsky Beach Road and Bridge Access Road north to the junction of Bridge Access Road and Kenai Spur Highway.
}

Combellick and Pinney, 1995). Across Cook Inlet to the west, Redoubt Volcano (3,108 m [10,197 ft] elevation) has erupted frequently in late Quaternary time, spreading thin tephras across the Kenai Peninsula lowland (Riehle and others, 1981; Riehle, 1985; Begét and Nye, 1994; Begét and others, 1994; Reger and others, 1996). Historic eruptions of the volcano occurred in 1902 A.D., 1966 A.D., 1967? A.D., 1968 A.D., and 1989-1990 A.D. (Yount, 1990).

MP 0.6, Bridge Access Road. Crossing of lower Kenai River on Warren Ames Memorial Bridge. Drilling for the bridge crossing indicates that the fine-grained estuarine deposit is $8 \mathrm{~m}$ (26 ft) thick beneath the terrace 


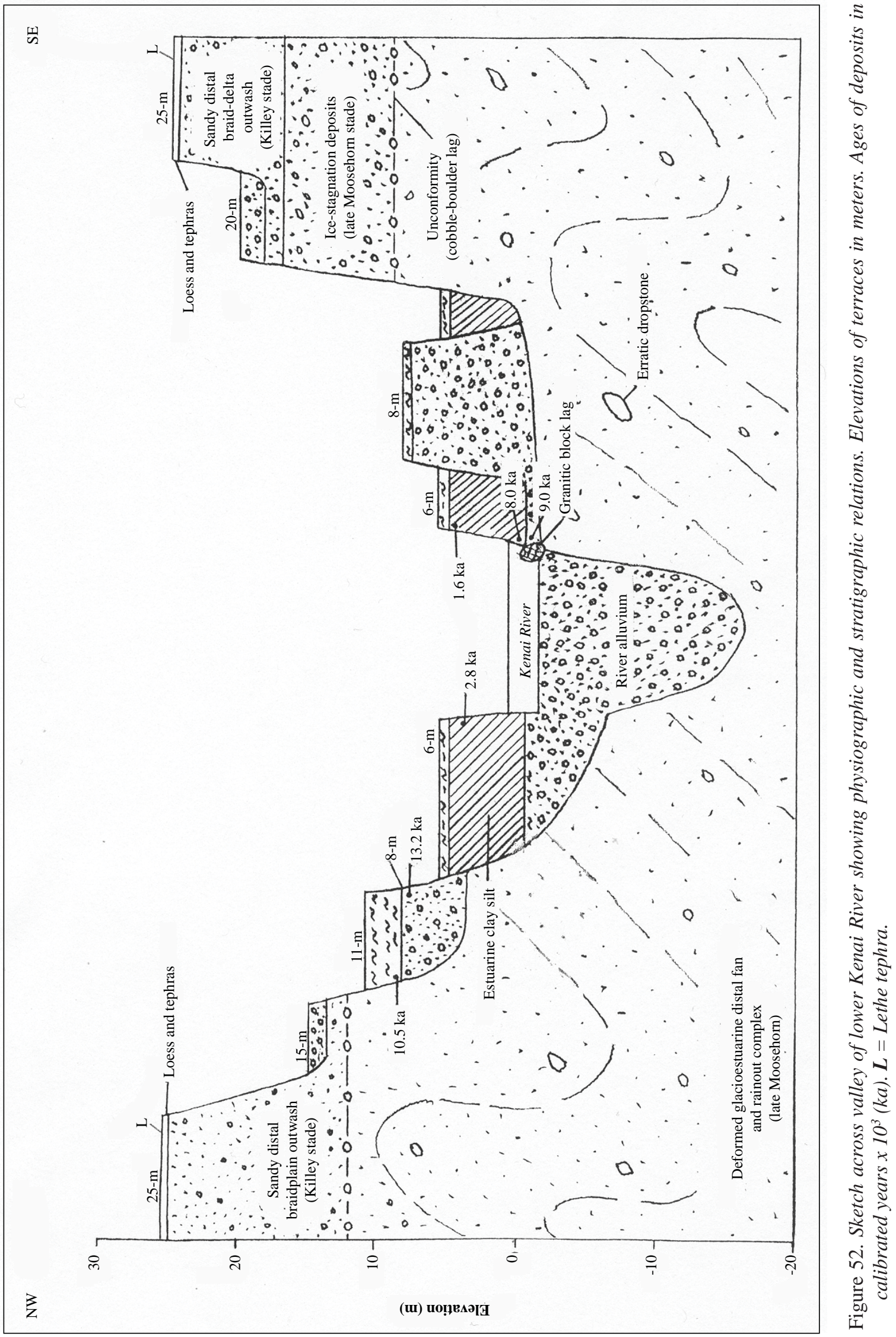


tread on the north side of the lower Kenai River and 16 m (52 ft) of alluvium of Elmendorf age fill a channel that was cut as deep as $17 \mathrm{~m}$ (56 ft) below sea level beneath the bridge (fig. 52) (Utermohle and Munson, 1972). The tree-covered terrace at $\sim 8 \mathrm{~m}(\sim 26 \mathrm{ft})$ elevation upstream of the bridge is underlain by sandy pebble gravel alluvium of Elmendorf age and is surrounded by fine-grained post-Elmendorf estuarine deposits. Large granitic erratics, left as lag by erosion of the underlying deformed distal fan-rainout glacioestuarine complex of late Moosehorn age (fig. 52), are visible along the riverbank during low water levels. Water-well logs indicate that this glacioestuarine complex is underlain by till of early to middle Moosehorn age (Anderson, 1971, 1972; Anderson and Jones, 1972).

MP 2.7, Bridge Access Road. Begin ascent to 25-m ( 80-ft) surface at Kenai.

MP 3.3, Bridge Access Road. Junction with Kenai Spur Highway (MP 10.8). ${ }^{11}$ Turn left (west) on Kenai Spur Highway. We are driving across the sandy distal surface of an extensive outwash braidplain (fig. 52) that was built into shallow glacioestuarine waters of ancestral Cook Inlet during the Killey stade by braided proglacial streams draining ice fronts in the Salamatof-Nikiski area to the north. We will return to Stop 7 in Kenai after we explore features north along the Kenai Spur Highway.

MP 11.7, Kenai Spur Highway. Crossing the first of two large, deep gullies cut into distal braidplain sands and underlying subestuarine fan-complex deposits (fig. 53) by drainage from an extensive patterned fen north of Kenai (sheet 4 ). We will cross the second gully in $0.5 \mathrm{~km}(0.3 \mathrm{mi})$.

MP 13.8, Kenai Spur Highway. Wildwood Drive marks the approximate midpoint of distal braidplain deposits along the Kenai Spur Highway north of Kenai (fig. 53). The gradient of the distal surface is consistently $\sim 1-2 \mathrm{~m} / \mathrm{km}$ ( 5-10 ft/mi) ( 0.1-0.2 percent), and surface relief is very low. Mean grain size of these deposits gradually increases northward toward former glacial margins of Killey age (sheet 4) that were the sources of sediment-charged proglacial streams that built the braidplain.

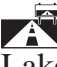

MP17.2, Kenai Spur Highway. Lower Salamatof Lake, a large kettle lake, documents the outer (early) Killey ice limit of the lowland ice sheet from northwestern sources (sheet 4). Ice-proximal outwash slopes $\sim 5-8 \mathrm{~m} /$ $\mathrm{km}$ ( 26-42 ft/mi) ( 0.5-0.8 percent), the frequency of pitting increases, and local surface relief increases

\footnotetext{
${ }^{11}$ Mileposts along Kenai Spur Highway are referenced from the junction of the Sterling Highway (MP 94.1) and the Kenai Spur Highway at Soldotna, MP 0 (sheet 3).
}

from $\sim 4 \mathrm{~m}(\sim 13 \mathrm{ft})$ to $>50 \mathrm{~m}(>165 \mathrm{ft})$ as we approach progressively younger ice limits of Killey age.

MP18.8, Kenai Spur Highway. Here we enter the shallow basin of a vegetated former kettle lake that was drained when recession of the nearby coastal bluff intersected the margin of the lake. Erosion of sand-rich braidplain deposits along the Cook Inlet coast north of Kenai is initiated when powerful waves driven by strong winds from western quadrants attack the base of the coastal bluff during episodic summer and fall storms. Retreat of the coastal bluff occurs as granular bluff sediments ravel back to quasi-stable angles (30-35²), approaching the angle of repose of the sediments, and sandy colluvial aprons build against the base of the slope. However, these colluvial aprons offer little protection because they are easily eroded during subsequent hightide cycles. During a powerful storm in October 2002 A.D., which was termed a '30-year event' (implying that a storm of this magnitude occurs 3.3 times a century), the base of the coastal bluff in this area was notched $\sim 1.6 \mathrm{~m}(\sim 5 \mathrm{ft})$, and in less than a month the subsequent wave of surface raveling had progressed 3 to $6 \mathrm{~m}$ (10 to $20 \mathrm{ft}$ ) up the bluff face (R.D. Reger, unpublished data). Retreat of the bluff during a given cycle is completed when the wave of raveling reaches the top of the bluff. Discussions with local residents indicate that the average rate of bluff retreat in the Salamatof area is $\sim 0.6$ m ( 2 ft) per yr. Based on slope geometry, local bluff recession resulting from the October 2002 A.D. storm will be $\sim 17 \mathrm{~m}(\sim 56 \mathrm{ft})$. In spite of widespread local knowledge of this destructive process because of considerable property loss, world-class views across Cook Inlet continue to attract buyers of bluff properties with predictable results (fig. 54).

AP 21.8, Kenai Spur Highway. Salamatof Road provides public beach access through the basin of a drained former kettle lake. Plafker (1956) documented up to $3.5 \mathrm{~m}(11.5 \mathrm{ft})$ of diatomaceous earth overlying $\sim 1 \mathrm{~m}$ ( $\sim 3 \mathrm{ft})$ of fine-grained lacustrine sediments in this basin. ${ }^{12}$ The diatomaceous earth is a lightweight material composed dominantly of tests of silica-secreting, colonial, freshwater algae (diatoms) with minor siliceous spicules of freshwater sponges and $\sim 10-20$ percent loess.

Salamatof Beach is famous for the agates found here. These agates, which are generally pebble size or smaller, were carried here by Naptowne glaciers from the west side of Cook Inlet, where they were probably scoured from Mesozoic volcanic rocks (Magoon and others,

\footnotetext{
${ }^{12}$ Karlstrom (1964, table 2) provided a more comprehensive list of freshwater diatoms from the Nikiski area, which were identified by K.E. Lohman. Unfortunately, the three collection sites are not clearly identified.
} 

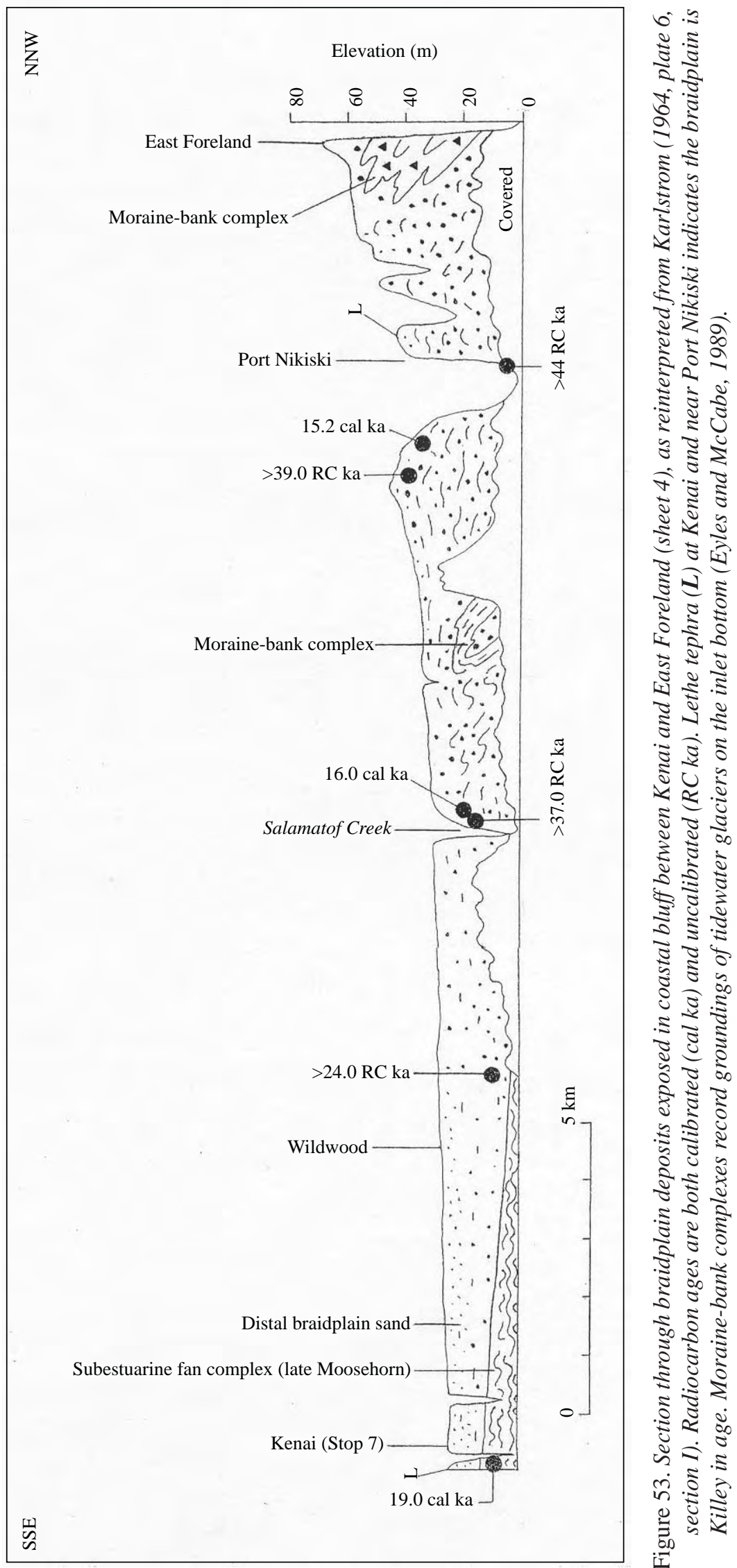
1976; Reed and others, 1983), and were deposited in iceproximal subestuarine fans (fig. 55). Attempts to stabilize the coastal bluff behind local refineries have sealed the source of beach agates, and as they are collected in the future, these prized stones will become progressively smaller and rarer.

Attempts to protect the local bluff from wave attack have included proposals to collect the numerous glacial erratics along the beach and stack them against the base of the bluff (fig. 55). However, removal of these boulders could disrupt the cobble-boulder lag beneath the gravel berm and beach deposits, and vibrations by heavy vehicles during the removal process could destabilize the liquefiable fine-grained rainout complex protected by the erratics and lag, likely exacerbating bluff erosion.

In contrast to the southern coast of the Kenai Peninsula lowland (Magoon and others, 1976), the north coast of Cook Inlet along the west side of the Kenai Peninsula lowland does not have exposed bedrock. According to Anderson and Jones (1972, p. 17), Tertiary bedrock

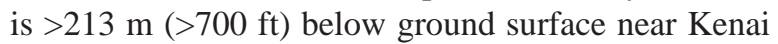
and rises northward to $\sim 91 \mathrm{~m}(\sim 300 \mathrm{ft})$ below ground surface in the Captain Cook State Park area. Bedrock

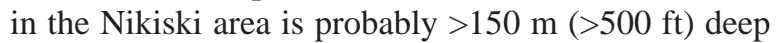
(Nelson, 1981).

MP 26.1, Kenai Spur Highway. Settlement of Nikiski, which serves as a logistical-support base for oil platforms in upper Cook Inlet.

MP 26.7, Kenai Spur Highway. Nikishka Beach Road provides public access to the northern beach.

A MP29.9, Kenai Spur Highway. Daniels Lake is an exceptionally large kettle lake that straddles the intermediate glacial limit of Killey age (sheet 4).

MP 33.8, Kenai Spur Highway. For the next $0.5 \mathrm{~km}(0.3 \mathrm{mi})$ we follow along the southeastern base of a high scarp that coincides with the intermediate Killey-age limit of ice from the northwest (sheet 4).

AP 35.1, Kenai Spur Highway. Crossing of Bishop Creek, which drains several kettle lakes and former kettle lakes between ice limits of early and intermediate Killey age (sheet 4).

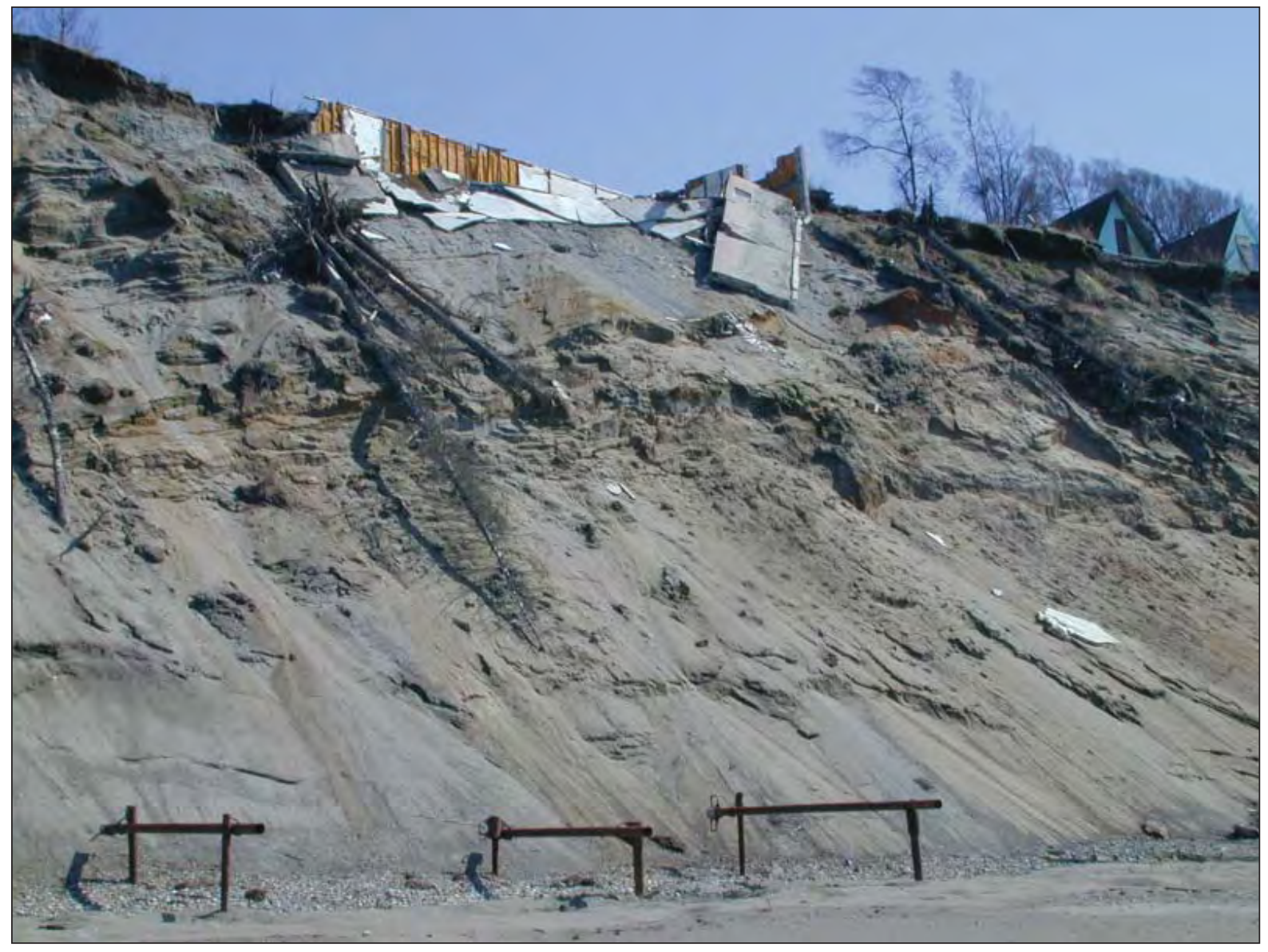

Figure 54. Building destroyed by retreat of 30-m- (98-ft-) high, sand-rich coastal bluff in the Salamatof area (photograph taken 5-4-04). 


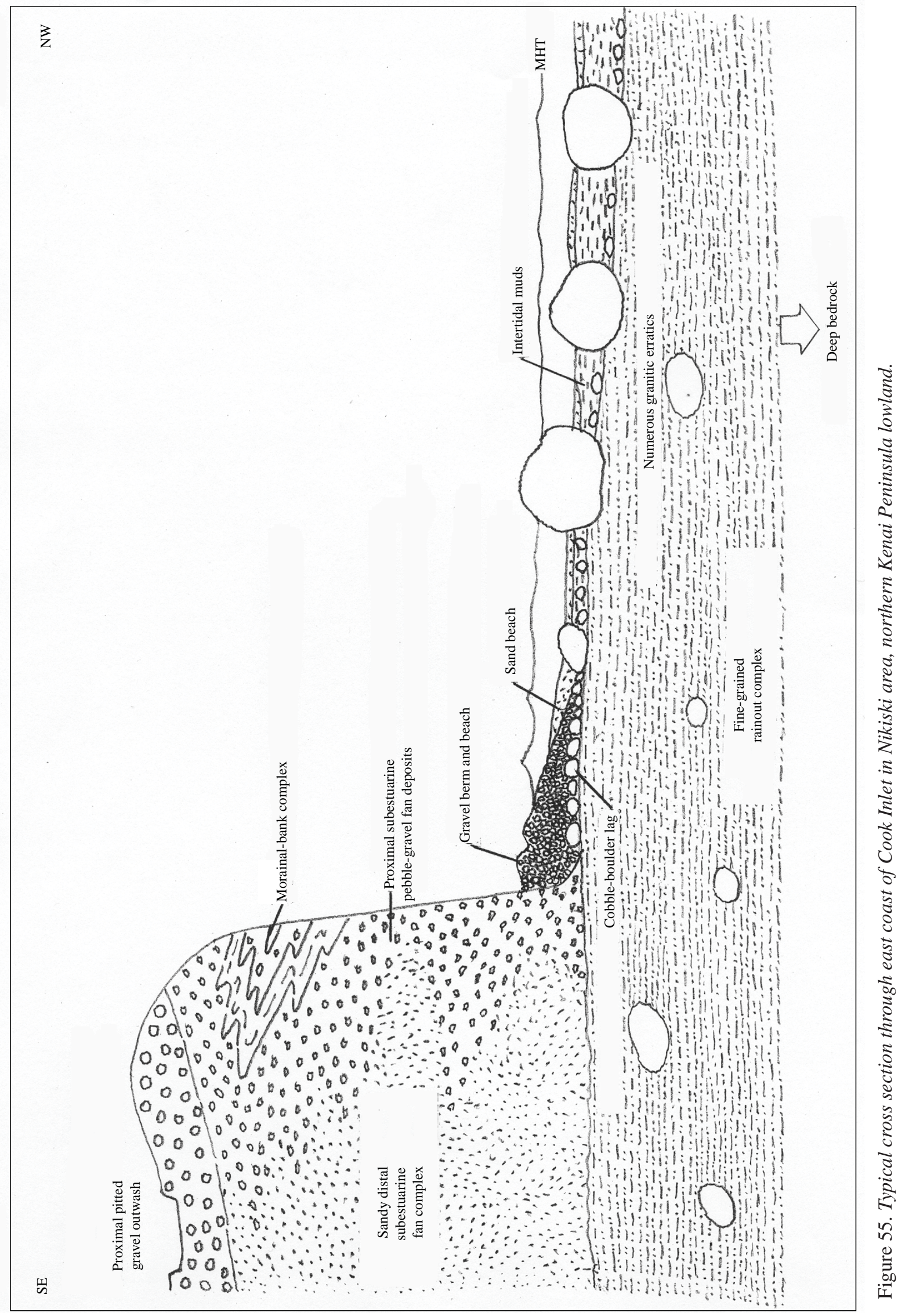




\author{
MP 35.5, Kenai Spur Highway. Entering Captain \\ Cook State Park.
}

MP 36.8, Kenai Spur Highway. Overlook of Stormy Lake, a large kettle lake that drains northwestward into lower Swanson River (sheet 4). Peat-filled satellite basins and high-level former shorelines indicate that ancestral Stormy Lake was much larger.

MP 38.7, Kenai Spur Highway. Crossing of the lower Swanson River on Clint Starnes Memorial Bridge. In this reach, the Swanson River is tidally influenced. Just upstream a large granitic erratic is visible in the floodplain.

Between the sharp elbow of the Swanson River and Cook Inlet, the stream is underfit and winds across a wider, slightly meandering valley (sheet 4). Clearly, the stream that cut the valley was quite unlike the modern Swanson River. Physiographic evidence indicates that the lowest $15.7 \mathrm{~km}(9.8 \mathrm{mi})$ of the ancestral Swanson River drained ice-marginal lakes of early Killey age and used to flow southward to join proglacial Swanson River, in the opposite direction that it flows today, and at that time the slightly meandering channel was cut (fig. 56A). We speculate that, as the glacier thinned and receded northwestward and the level of the ice-marginal lakes lowered, this tributary cut into drift of Moosehorn age for a time, initially deepening the tributary valley (fig. 56B), but eventually the rate of ice recession and lowering of the associated ice-marginal lake increased to a degree that downcutting could no longer keep pace, and lake overflow ceased (fig. 56C). At this stage, a greatly reduced volume of local drainage likely flowed southward in the initial tributary valley, and perhaps a lesser volume of local drainage in the area of the present mouth of the Swanson River flowed northward down the paleoslope left by the recession of the glacier and lake. After withdrawal of glacial ice from the northwestern Kenai Peninsula lowland, perhaps $\sim 17.5$ cal kya, glacioestuarine waters of ancestral Cook Inlet separated tidewater glaciers from the Kenai Peninsula lowland and bluff recession commenced along the western coast as the Kenai Peninsula lowland rebounded. We speculate that the small stream that flowed northward at the present mouth of the Swanson River was able to accelerate its erosion in response to steeper gradients resulting from isostatic rebound and recession of the coastal bluff and eventually was able to cut southward along the former tributary valley and intersect the nonglacial drainage of the Swanson River, forming the elbow of capture during the Skilak stade (fig. 56D) (sheet 4).

\section{STOP 6. CAPTAIN COOK STATE PARK PICNIC AREA}

MP 39, end of Kenai Spur Highway. Turn left and drive $0.8 \mathrm{~km}(0.5 \mathrm{mi})$ past Discovery Campground (on the left) and, turning right, proceed to Discovery Picnic Area for Stop 6.

We are standing at the bluff of northern Cook Inlet close to the outer limit of early Killey ice from the northwest (sheet 4). From the west to the northwest across Cook Inlet the spectacularly rugged splendor of the Chigmit, Neacola, and Tordillo mountains of the southern Alaska Range is spread before us, and at $104 \mathrm{~km}$ (65 mi) to the northwest we see Mt. Spurr Volcano (3,374 $\mathrm{m}$ [11,069 ft] elevation), which erupted in 1953 A.D. and 1992 A.D. (Waythomas and Nye, 2002), crowning the southern Tordillo Mountains. Piedmont slopes and the coastal plain were intensively scoured by Naptowne glaciers, and glacial till is thin and discontinuous there. The products of that scouring were deposited in the Kenai Peninsula lowland. Cook Inlet is $35 \mathrm{~km}$ ( 22 mi) wide here, and we can see several oil platforms scattered across its surface (Boss and others, 1976; Magoon and others, 1976). Many of these platforms are founded on submarine moraines of Skilak age (fig. 10). Tidal range here is large, $9.4 \mathrm{~m}(30.8 \mathrm{ft})^{13}$, and at intermediate to low tides, literally hundreds of large erratics dot the tidelands in front of us (fig. 57). Because of rapid changes in water level and the presence of very soft sediments, we do not recommend walking alone in the tideland, and we encourage visitors to carefully check tide tables to determine the timing of local tidal changes.

The coastal bluff in this area displays a variety of glacial and postglacial features, and we can observe these features by descending the access road to the beach. To the immediate southwest along the bluff are exposed up to $4 \mathrm{~m}(13 \mathrm{ft})$ of fine-grained lake sediments overlying blocky till and rusty cobble gravel. Capping the section are up to $2 \mathrm{~m}$ (6.6 ft) of fibrous peat with interbedded thin, light-colored tephras. The lake deposits contain numerous calcareous shells of freshwater mollusks. Represented are high-spiralled Stagnicola (Stagnicola) elodes (Say, 1821) (Common Stagnicola), planispiralled Gyraulus deflectus (Say, 1824) (Irregular Gyraulus) and Gyraulus parvus (Say, 1817) (Modest Gyraulus), and a small fingernail clam, Sphaerium (Sphaerium) nitidum Clessin, 1876 (Arctic-alpine Fingernail Clam). ${ }^{14}$ These fossils date 3,670 \pm 61 RC yr B.P. $(2,137 \pm 61$ cal yr B.P.) (GX-16,526) (R.D. Reger, unpublished data). Also of interest near the top of the lake section are lightweight yellowish layers that appear to be deformed by

\footnotetext{
${ }^{13} 2007$ southcentral Alaska tide tables: Soldotna, Pioneer Publishing, 112 p.

${ }^{14}$ Taxonomy used by Clarke (1981).
} 
N

A. Killey readvance

Proglacial

Swanson River

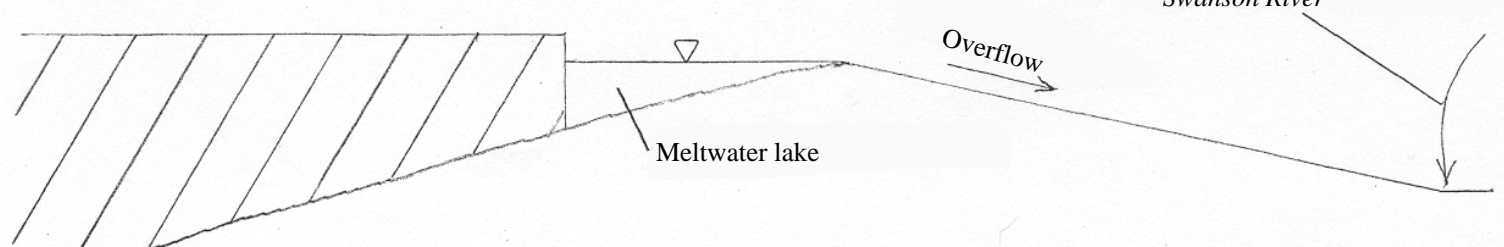

B. Late Killey recession

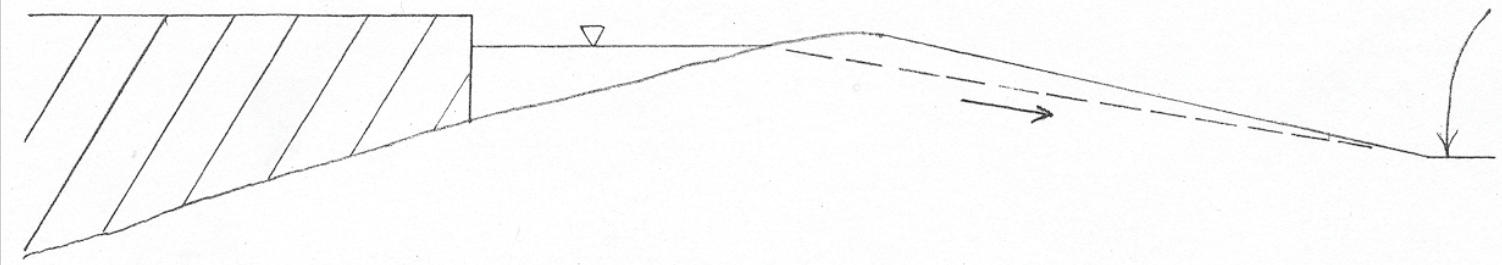

C. Late Killey recession

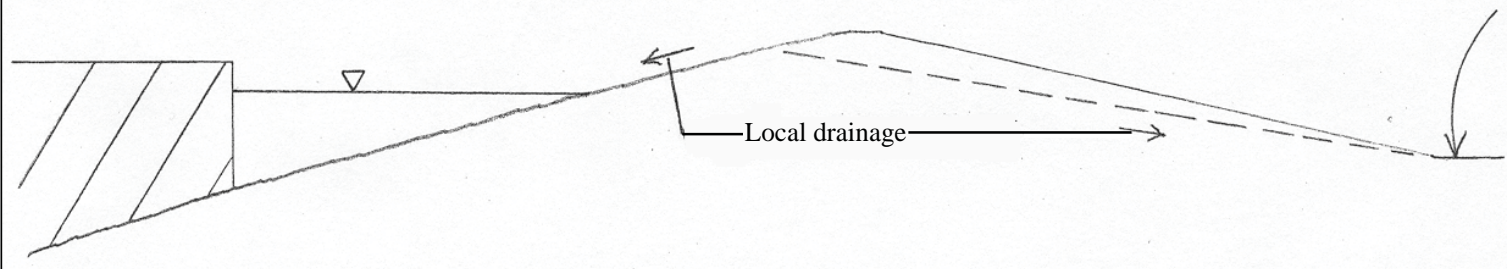

D. Skilak stade

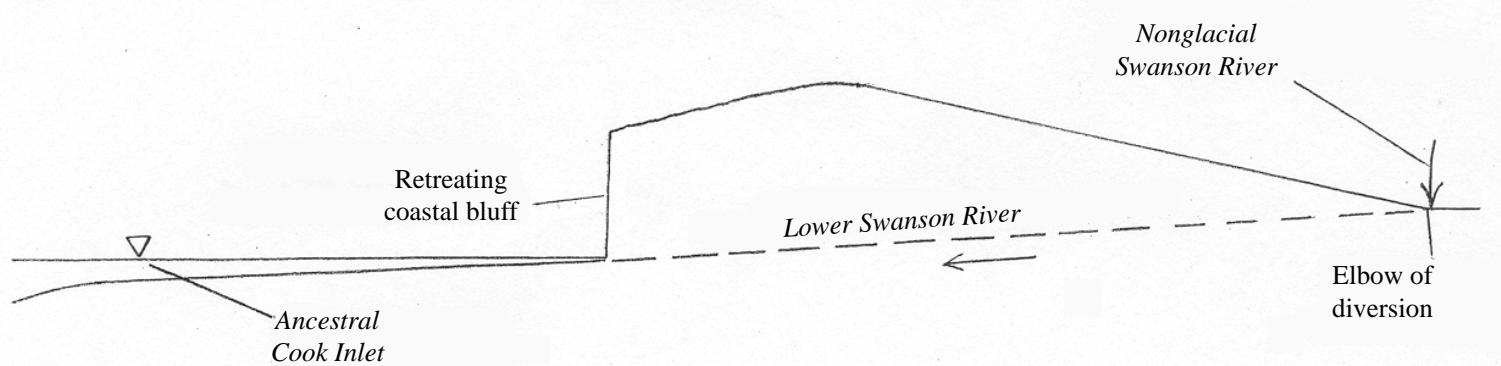

Figure 56. Possible evolution of lower Swanson River. 


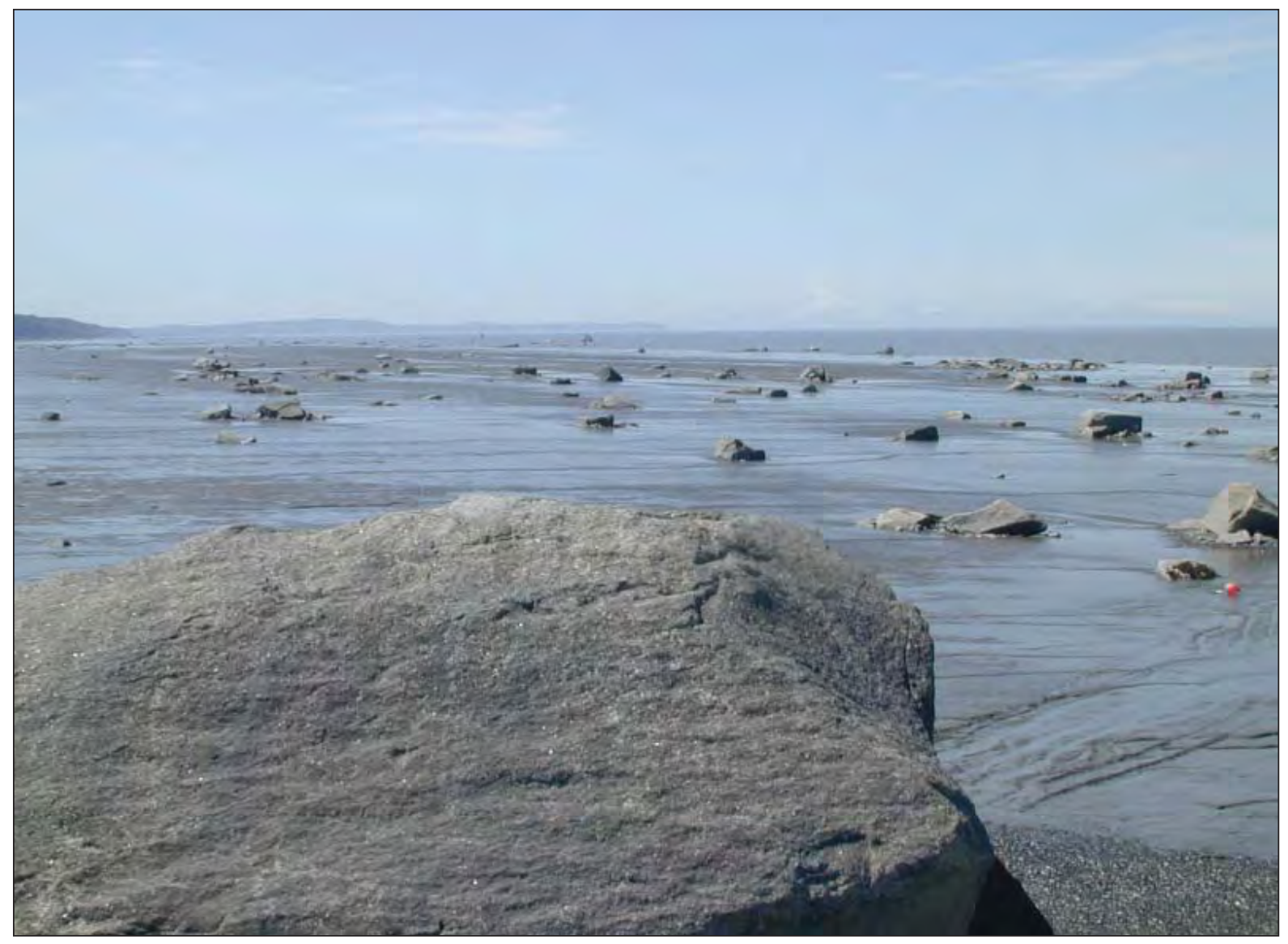

Figure 57. Numerous large erratics deposited by glaciers from west side of Cook Inlet 18.0 cal kya in Captain Cook State Park, northwestern Kenai Peninsula lowland (photograph taken 6-6-04).

sublacustrine sediment flows. These layers are primarily composed of striated siliceous tubes of Equisetum. Near the middle of the lake section is a zone of tightly folded lake sediments that could be the result of liquefaction during an earthquake that occurred $>3.7$ RC kya (2.1 cal kya).

To the northeast along the bluff, sandy lake-bottom sediments that are low in the section are overlain by bouldery till of early Killey age, which contains a variety of erratics brought here from the west side of Cook Inlet. The beach is crowded with blocks and boulders of exotic igneous, metamorphic, and sedimentary rock types that were released from this till by erosion of the bluff. As we continue northeastward, we note that the till descends beneath bedded sands deposited in an ice-impounded lake of early Killey age, perhaps 18.0 cal kya. Deposits of this ice-marginal meltwater lake extend for several miles northeast from here nearly to Point Possession (Karlstrom, 1964, sheet 6, sections II, III, IV, and V) (fig. 9). Unique concretions that probably formed in this meltwater lake, just as carbonate-cemented concretions formed in meltwater lakes in the Copper River basin and on the Seward Peninsula (Reger and Hopkins, 1995), are found scattered along the beach and in the nearby tidelands. They are composed entirely of well-cemented, thinly bedded, fine-grained lake sediments. Undeformed bedding ultimately produced discoid concretions, and layers that were deformed before lithification ultimately produced unusual forms (fig. 58).

\section{STOP 7. RIVER BLUFF AT KENAI}

Our next stop in Kenai is reached by returning on Kenai Spur Highway. Drive to MP 10.9, Kenai Spur Highway, and turn right (south) on Spur View Drive. Proceed across the Frontage Road past the Senior Citizens Community Center and, bearing left, stop in the parking area near the high river bluff (sheet 4).

\section{BLUfF SECTION}

The most significant known locality for definitive evidence concerning the early Naptowne glaciation in the middle Cook Inlet region is this $25-\mathrm{m}$ - (82-ft-) high river bluff at Kenai (sheet 4). This extensive exposure consists of two sediment packages (fig. 59). The lower half of the high bluff is a medium to dark gray, complex 


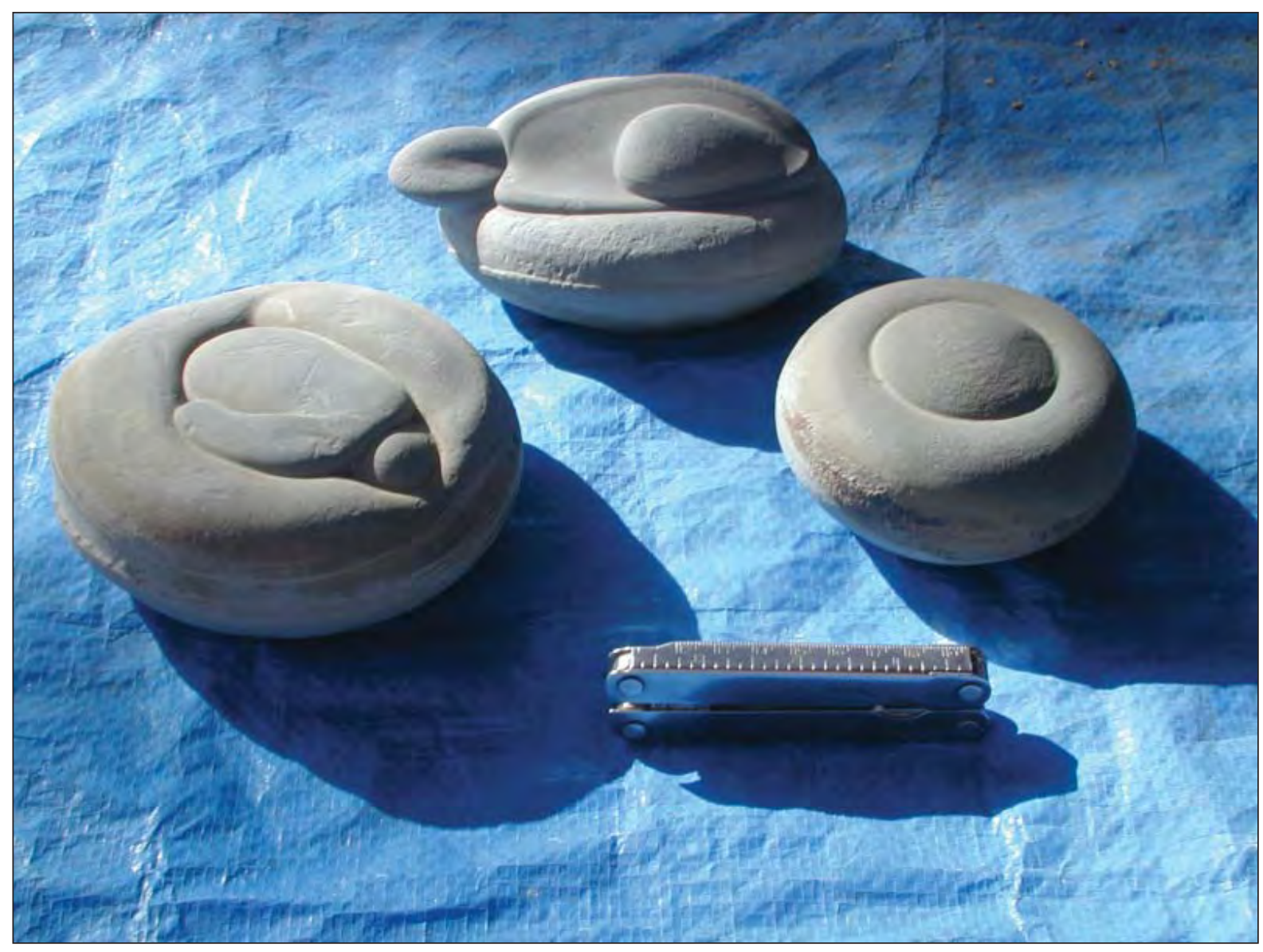

Figure 58. Concretions formed in lake beds northeast of Captain Cook State Park and found in nearby tidelands. Folded knife is $10 \mathrm{~cm}$ (4 in) long.

sandy diamicton (fig. 60), which represents the timetransgressive Bootlegger Cove Formation in the middle inlet area and is a millennia or two older than the same formation in the upper inlet area (Reger and others, 1995). A line of iron-oxide-rich springs emerging from the bluff marks the top of this unit, which is less permeable than the overlying friable sand. The upper $\sim 0.4 \mathrm{~m}$ $(\sim 1.3 \mathrm{ft})$ of the diamicton is composed of massive silt with some clay, numerous angular to subangular pebbles, and scattered cobbles. Although it looks like a glacial till, this unit is a rainout diamicton deposited beneath turbid plumes and melting icebergs near a calving tidewater glacier or tabular ice shelves floating in glacioestuarine ancestral Cook Inlet, which was deep enough to allow large ice masses to float (fig. 61). Beneath the rainout diamicton is a discontinuous lag $\sim 25 \mathrm{~cm}(\sim 10$ in) thick, which is composed of pebble gravel with some medium to coarse sand and numerous scattered, dismembered, and broken calcareous plates of Balanus evermanni, an exceptionally large barnacle that no longer lives in Cook Inlet but survives attached to rocks in deep waters of Prince William Sound (Nora Foster, 1994 oral com- mun.). We believe that this depauperate fauna ${ }^{15}$ lived in the tide-dominated waters of ancestral Cook Inlet attached to large erratics scattered on the inlet floor and their postmortal remains were scattered by tidal currents and quickly buried.

The lower $12 \mathrm{~m}$ (40 ft) of the lower package appears homogeneous from a distance, but close inspection reveals that the fine sand with some silt, trace gravel, scattered striated cobbles and boulders, and scattered plates of Balanus evermanni ${ }^{16}$ are actually deformed into small isoclinal parallel folds and thrust faults. The sandy diamicton was deposited as a distal fan-rainout subestuarine complex on the inlet floor beneath sandcharged plumes that emerged from beneath a calving

\footnotetext{
${ }^{15}$ Depauperate compared to mollusc-dominated fauna of Elmendorf age in upper Cook Inlet (Reger and others, 1995, 1996). Samples of silty sand and diamicton were submitted for microfossil analysis and found to be barren, except for a single Diatoma sp., which was probably recycled from Tertiary rocks (Micropaleo Consultants, Inc., 1993, written commun.).

${ }^{16}$ Rare shells of Buccinium cf. glaciale originally reported by Reger and others (1996) are now considered to be derived from middens of the Kenaitze village that formerly was located at the top of the bluff.
} 
tidewater glacier or ice shelves (efflux jets of Eyles and McCabe, 1989) (fig. 61). The barnacle plates date 16,480 \pm 170 RC yr B.P. (19,246 \pm 170 cal yr B.P) (WSU-4,304), which is the oldest radiocarbon date for Bootlegger Cove Formation in the Cook Inlet region (Reger and others, 1996, fig. A20). The presence of these barnacle remains is definitive evidence that the glacial dam at the mouth of Cook Inlet was breached and marine waters invaded the Cook Inlet basin as far north as Kenai by 19.2 cal kya.

Consistent direction of overturning and displacement in the lower diamicton indicates that stress was consistently applied to inlet-bottom sediments from the northwest. We speculate that the scale and pervasive nature of the folding and the flat top of the lower package here and to the west (fig. 54) imply that the stress was probably produced not by winter inlet ice, but by a floating tabular ice shelf (with a fairly flat bottom) that coupled with soft, saturated sediments on the inlet bottom during exceptionally low tides as it moved toward the southeast. ${ }^{17}$ The combined thickness of the rainout diamicton at the top of the lower package and the under- lying gravel lag is $<1 \mathrm{~m} \mathrm{(}<3 \mathrm{ft}$ ), so they do not obscure significant relief on the underlying glacioestuarine distal fan and rainout complex. Clearly, the ice shelf was not grounded enough to produce moraine-bank complexes as occurred between Kenai and East Foreland (fig. 53). Deformed subestuarine sediments in a lower river-bluff exposure $8 \mathrm{~km}(\sim 5 \mathrm{mi})$ southeast up the lower Kenai River indicate that the ice shelf grounded there in latest Moosehorn time (R.D. Reger, 2004). The gravel capping the subestuarine distal fan-rainout deposits probably formed a lag as strong currents scoured between the bottom of the ice shelf and the inlet floor, and the rainout diamicton at the top of the lower package was probably deposited beneath the turbid plume as the ice shelf receded northwest.

The 12-m- (39-ft-) thick, tan, upper facies in the bluff grades from a rippled, sandy pebble gravel with numerous thin partings of iron-oxide-stained detrital coal and thin clay layers low in the unit upsection to medium sand (fig. 59) and represents the distal facies of the braidplain we traversed past Killey ice limits in the

\footnotetext{
${ }^{17}$ Tidal range at Kenai is $9.1 \mathrm{~m}$ (29.9 ft) (2007 southcentral Alaska tide tables: Soldotna, Pioneer Publishing, 112 p.).
}

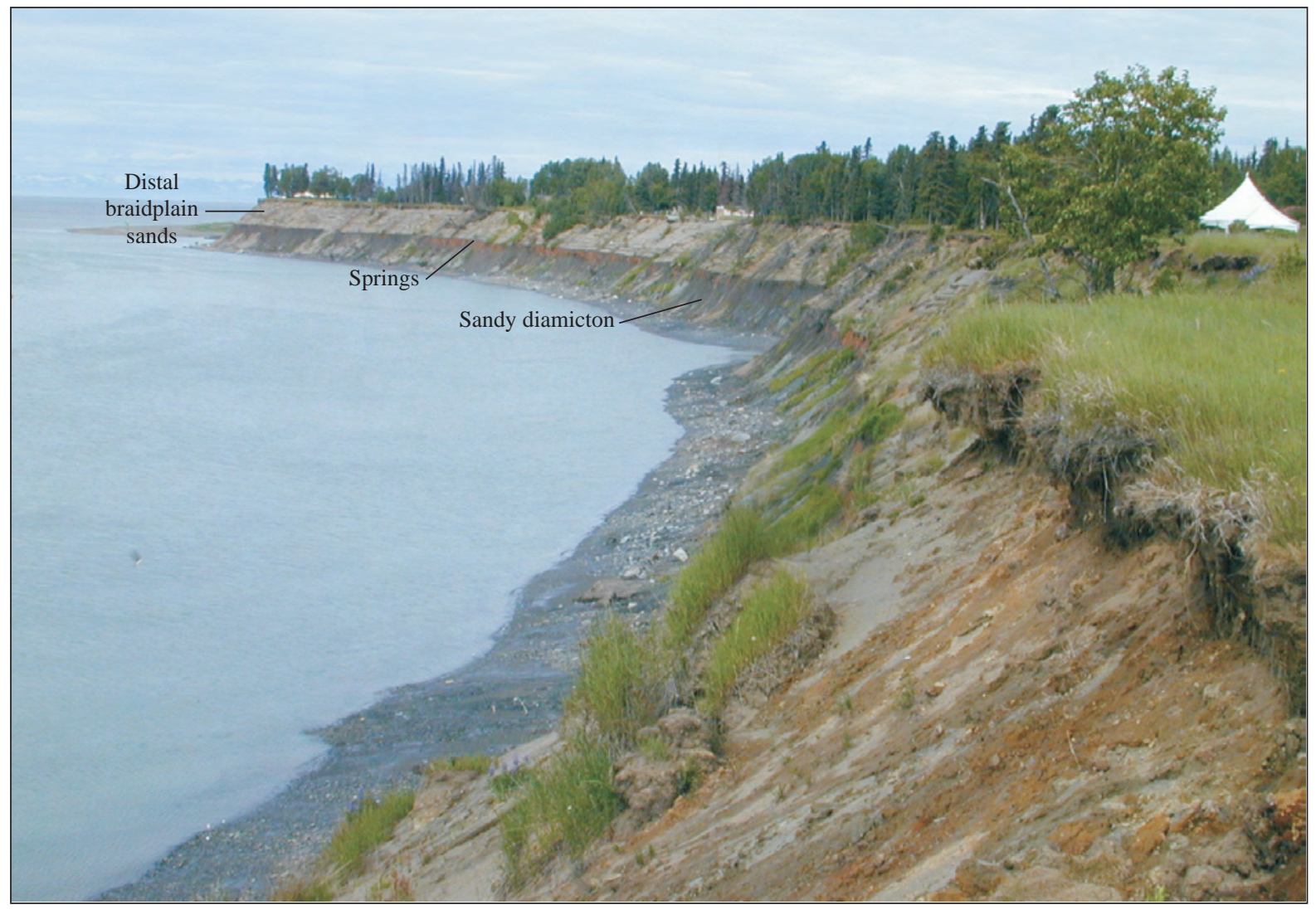

Figure 59. View west of eroding river bluff at Kenai, showing glacioestuarine deposits of late Moosehorn and Killey stades (photograph taken 6-19-06). 
Salamatof-Nikiski area (sheet 4). Nearby, Lethe tephra is present near the base of the $\sim 0.5-\mathrm{m}-(\sim 1.5-\mathrm{ft}-)$ thick loess overlying these deltaic sands (Reger and others, 1996, fig. A19), indicating that the braidplain sediments are Killey in age.

\section{ChANGES IN RELATIVE SEA LEVEL}

The sight of deep-inlet bottom sediments $12 \mathrm{~m}$ (39 ft) above the waters of modern Cook Inlet encourages questions about changes in relative sea level, both long term and short term. Changes of land level relative to sea level can be caused by complex interactions of several factors, including tectonic uplift and subsidence due to earthquakes, fault activity, and the growth of bedrock structures, by isostatic adjustments of the crust caused by glacier advance and retreat, and geoidal changes related to redistribution of mass in the Earth as well as eustatic changes related to changes in volume of the ocean (Nelson and others, 1996).

\section{Land-level changes}

Eastern and northern Cook Inlet have been the focus of land-level studies since the 1964 A.D. Alaska earthquake. Post-earthquake regional surveys measured $\sim 0.3$ to $1.3 \mathrm{~m}(\sim 1 \mathrm{ft}$ to $4 \mathrm{ft}$ ) of coseismic subsidence of the western Kenai Peninsula lowland, with the greatest subsidence ( 1.8 m [ 6 ft]) measured at Portage (Plafker, 1965, 1969) (fig. 62). Lowering of coastal lands allowed salt water to invade terrestrial environments, quickly killing coastal forests and producing 'ghost' forests and burying surface peats, composed of highmarsh plants, with intertidal muds containing scattered remains of low-marsh plants ${ }^{18}$ (Ovenshine and others, 1976; Bartsch-Winkler and Schmoll, 1987; Atwood and others, 2001). Initial dating of coseismically subsided freshwater peats identified several large-magnitude, subduction-zone earthquakes that have shaken southcentral Alaska about every 700-900 RC yr ( 700-800 cal yr) (Combellick, 1991, 1992, 1993, 1994, 1997; Combellick and Reger, 1994; Mann and Crowell, 1998), but estimates of recurrence intervals based on imprecise dating of bulk peat samples were criticized and are being re-evaluated (Bartsch-Winkler and Schmoll, 1992; Hamilton and others, 2005).

To more precisely quantify coseismic and interseismic land-level changes along the coast, diatoms in peat-mud couplets formed

\footnotetext{
${ }^{18} \mathrm{High}$-marsh refers to the vegetated upper intertidal zone that is infrequently flooded by salt water and low-marsh refers to the lower intertidal zone that is flooded at least daily by salt water (Combellick, 1997).
}

Figure 60. Stratigraphy exposed in bluff of lower Kenai River at mouth of Ryan's Creek in Kenai (modified from Reger and others, 1996, fig. A20). 


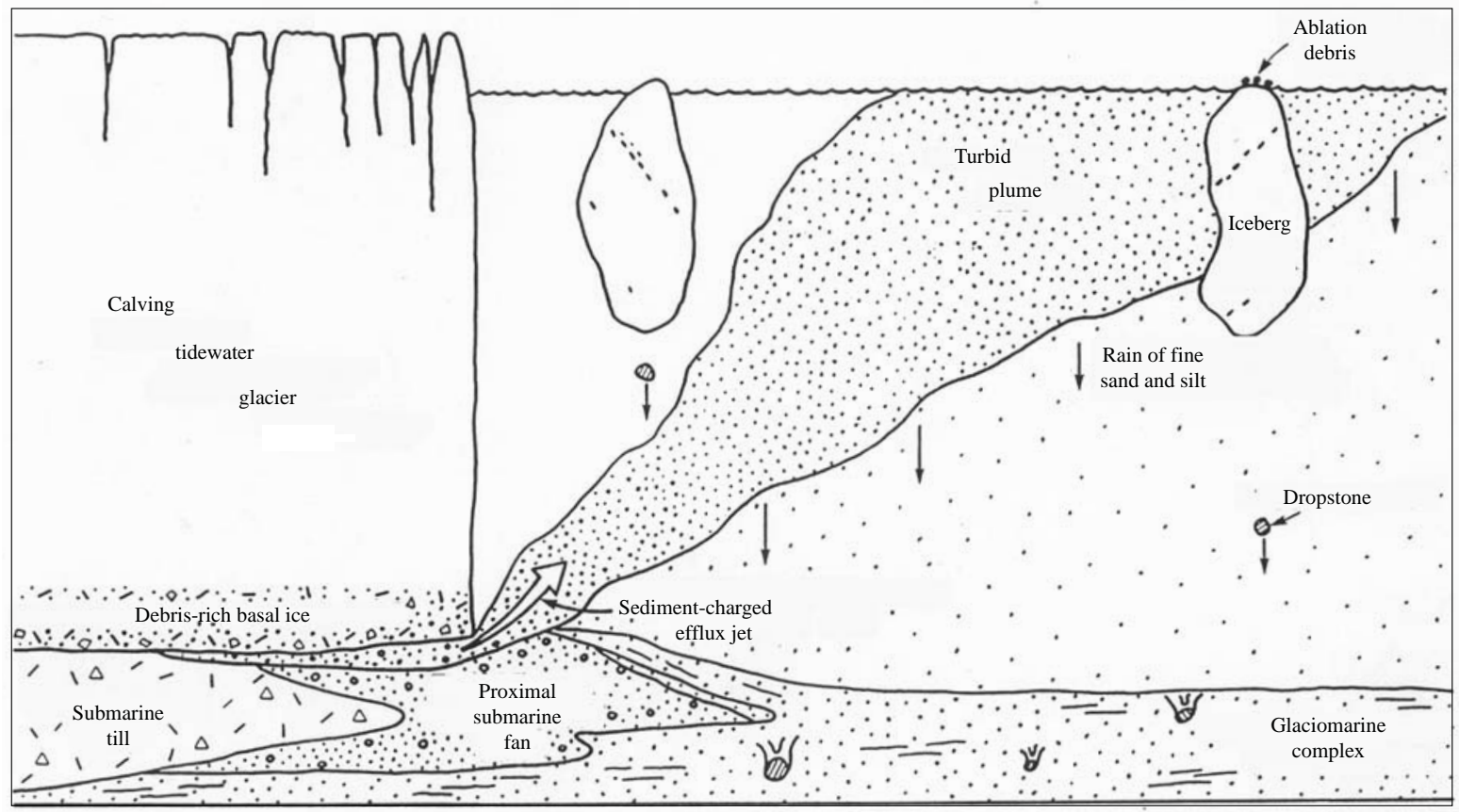

Figure 61. Depositional processes and sediments near a calving tidewater glacier or ice shelf (modified from Eyles and McCabe, 1989, fig. 9).

during past earthquakes were analyzed using transfer functions that relate modern diatom assemblages with varying degrees of salinity tolerance to elevation relative to Mean Higher High Water (Hamilton and Shennan, 2005a, b; Hamilton and others, 2005; Shennan and Hamilton, 2006). Applications of these transfer functions to fossil diatom assemblages extracted from cores indicate within centimeters the magnitudes of relative sea-level changes produced during rapid coseismic subsidence and later as the land slowly recovered and identified preseismic signals of impending earthquakes that may be useful for predicting future large-magnitude earthquakes. By precisely dating subsided peats, regional changes in land level can be assessed for specific seismic events. Diatom-based studies here at Kenai indicate that $1.1 \mathrm{~m}$ (3.6 ft) of subsidence occurred during a large-magnitude earthquake $\sim 1,400-1,500 \mathrm{cal}$ ya and $0.4 \mathrm{~m}(1.3 \mathrm{ft})$ of subsidence occurred during the 1964 A.D. Alaska earthquake (Hamilton and Shennan, 2005a, fig. 10). So far, no definite record has been identified for subsidence at Kenai during the penultimate earthquake, which occurred $\sim 850-\sim 950 \mathrm{cal}$ ya and affected upper Cook Inlet. However, fluctuations of sea level documented at Kenai and Portage may be caused by isostatic subsidence related to Holocene glacier expansions in the Kenai Mountains and across Cook Inlet at $\sim 3,600 \mathrm{cal}$ yr B.P., $\sim 1,350 \mathrm{cal}$ yr B.P., and $650-100 \mathrm{cal}$ yr B.P. (Hamilton and Shennan, 2005a, b).

Almost certainly, slower changes in land level are caused by active bedrock structures, like growing anticlines, at depth. There is considerable evidence in seismic-reflection data, records of historic seismicity, and stratigraphy in trenches that faults and fault-cored anticlines are active in the upper Cook Inlet basin (Haeussler and others, 2000, 2002). The lack of thinning of Pliocene Sterling Formation strata across many folds indicates that those folds developed after most of the Sterling Formation was deposited, probably in Quaternary time. Possible physiographic evidence of recent activity includes diversion of the Ivan River and the Lewis River around growing subsurface anticlines in the northwestern Cook Inlet basin (Haeussler and others, 2000, fig. 1) and possible displacement of Swanson River by growth of the Swanson River anticline (Berg, 2001). The Kenai gas field in a faulted anticline to the south of us is the largest field in the Kenai area (Brimberry and others, 1997), and smaller gas fields are present near Sterling to the east and near Beaver Creek to the northeast (Haeussler and others, 2000, fig. 1), but whether these structures are tectonically active is unknown.

\section{Eustatic sea level rise}

Climatic warming following the climax of the last major glaciation caused glaciers worldwide to begin thinning and receding, increasing the volume of the world's oceans and causing a rise in eustatic sea level. Ultimately, this rising ocean apparently floated and caused the destruction of the glacier dam across the lower Cook Inlet basin, allowing marine waters into the basin as far north as Kenai by 19.2 cal kya. We have very little 
evidence about later eustatic changes of sea level and the effects of isostatic rebound and growth of bedrock structures. However, stratigraphic evidence collected at $\sim+2 \mathrm{~m}(\sim+6.5 \mathrm{ft})$ elevation (Reger and others, 1996, fig. A32) indicates that estuarine waters began invading lower Kenai River between 8.0 and $9.0 \mathrm{cal}$ kya.

\section{BASAL PEAT DATES AS EVIDENCE OF CLIMATIC CHANGE}

At many sites in the Kenai Peninsula lowland, basal peats date $\sim 5.0$ to $\sim 15.0 \mathrm{cal}$ ka younger than the ages of the underlying material (fig. 63). A careful analysis of charcoal, phytolith, insect, and microfossils residuals along these unconformities could yield interesting insights, perhaps explaining this widespread hiatus. For now, we speculate that peat accumulated during wetter climates and could have decomposed or burned during drier climates and that postglacial climates were simply too dry for peat accumulation in many sites. This explanation is consistent with the calculated Milankovitch maximum summer insolation dosage of 520 watts $/ \mathrm{m}^{2}$ in June at $60^{\circ} \mathrm{N}$ latitude $11-12 \mathrm{cal}$ kya (http://aom.giss. nasa.gov/srmonlat.html). The Holocene thermal maximum in Alaska is documented at several sites in Alaska between $\sim 9$ and $\sim 12$ cal kya (Kaufman and others, 2004), somewhat delayed from the theoretical maximum insolation, especially in southwestern Alaska (Hu and others, 1998; Brubaker and others, 2001).

In the Kenai Peninsula lowland the oldest surfacepeat dates cluster between 18.4 and 18.9 cal ka (fig. 63,

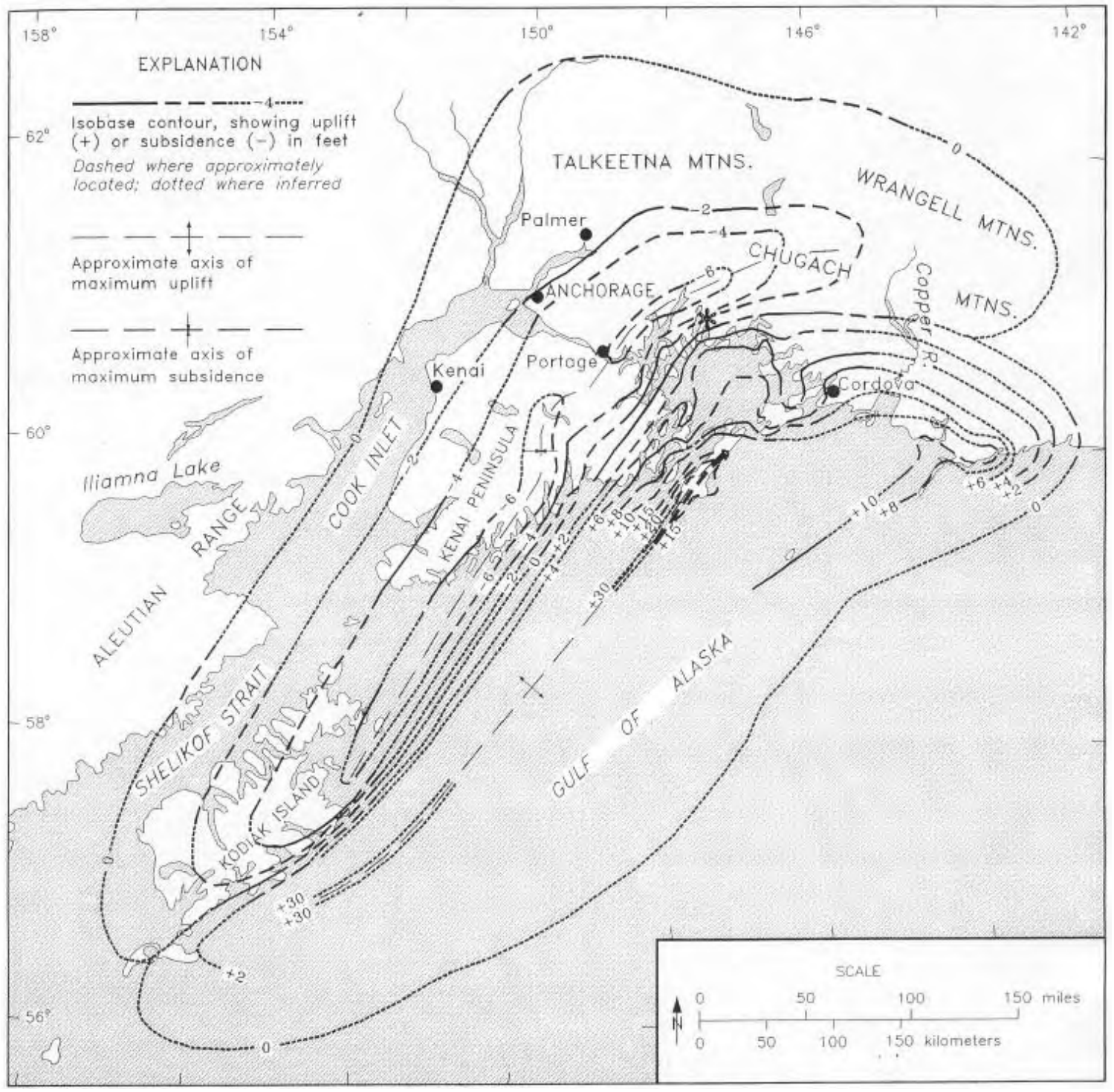

Figure 62. Map of vertical tectonic displacement caused by the great Alaska earthquake of March 27, 1964 (Walsh and others, 1995, fig. 2). Symbol * = epicenter. 


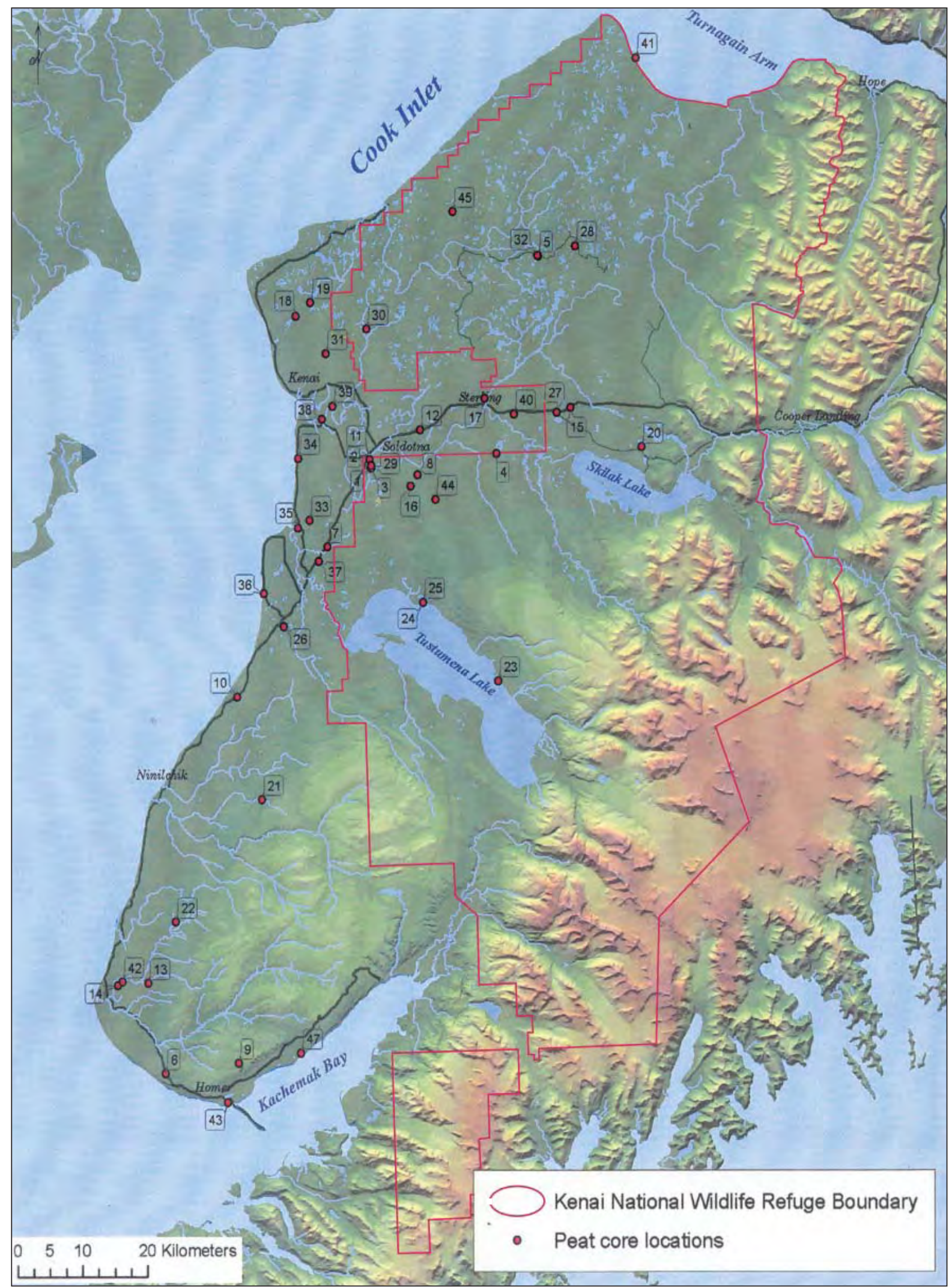

Figure 63. Peat coring sites in Kenai Peninsula lowland (names and location data shown in table 4). Compiled from published and unpublished sources by Edward Berg. 
Table 4. Names and location data of peat coring sites in Cook Inlet region (locations shown in fig. 63). Compiled from published and unpublished sources by Edward Berg.

\begin{tabular}{|c|c|c|c|c|}
\hline Site number and name & Datum & $\begin{array}{l}\text { Latitude } \\
\text { North }\end{array}$ & $\begin{array}{c}\text { Longitude West } \\
\text { West }\end{array}$ & $\begin{array}{c}\text { Basal Date } \\
\text { cal yr BP }\end{array}$ \\
\hline 1. Headquarters Lake & WGS 1984 & 60.46069 & -151.07697 & none \\
\hline 2. Headquarters Lake & “ & 60.45980 & -151.07777 & none \\
\hline 3. Headquarters Lake & “ & 60.45887 & -151.07573 & none \\
\hline 4. Browns Lake & “" & 60.47227 & -150.72969 & 1836 \\
\hline 5. Swan Lake Road & “ & 60.72786 & -150.59601 & none \\
\hline 6. Diamond Creek & “ & 59.67436 & -151.67888 & 13319 \\
\hline 7. Coal Creek & “ & 60.35759 & -151.20280 & none \\
\hline 8. Funny River Road & “ & 60.44847 & -150.94928 & 10834 \\
\hline 9. Wynn Nature Center & “ & 59.68582 & -151.47968 & 3298 \\
\hline 10. Que’ana Bar & “ & 60.16501 & -151.46017 & 10124 \\
\hline 11. Ski Hill Road & “ & 60.47008 & -151.08125 & 8418 \\
\hline 12. Big John's & “ & 60.50665 & -150.93837 & 7988 \\
\hline 13. Anchor Point Trail & “ & 59.79270 & -151.72067 & 10529 \\
\hline 14. Anchor Point & “ & 59.79050 & -151.80484 & 9778 \\
\hline 15. Watson Lake & “ & 60.52855 & -150.51976 & 10003 \\
\hline 16. Wood Cutting Road & “ & 60.43329 & -150.96970 & none \\
\hline 17. Moose River Road & “ & 60.54483 & -150.75793 & none \\
\hline 18. Nikiski South & “ & 60.66033 & -151.27629 & 2520 \\
\hline 19. Nikiski North & “ & 60.67752 & -151.23360 & 2746 \\
\hline 20. Engineer Lake & “ & 60.47334 & -150.32669 & none \\
\hline 21. Oilwell Road & “ & 60.02922 & -151.39954 & 3344 \\
\hline 22. Tall Tree Road & “ & 59.87185 & -151.64285 & 18387 \\
\hline 23. Point Lake & “ & 60.17522 & -150.74345 & 3851 \\
\hline 24. Fox Lake 1 & ‘ & 60.28090 & -150.94347 & 9711 \\
\hline 25. Fox Lake 2 & “ & 60.28140 & -150.94299 & none \\
\hline 26. Coho Loop & “ & 60.25485 & -151.32730 & none \\
\hline 27. Bottenintnin Lake & “ & 60.52331 & -150.55890 & 6811 \\
\hline 28. Jigsaw Lake & “ & 60.73930 & -150.49330 & 9550 \\
\hline 29. Headquarters Lake & “ & 60.46210 & -151.07550 & 10500 \\
\hline 30. No Name Creek & “ & 60.64080 & -151.08050 & 18480 \\
\hline 31. Marathon Road & “ & 60.61010 & -151.18960 & 7690 \\
\hline 32. Merganser Creek & “ & 60.72810 & -150.59890 & 13830 \\
\hline 33. K-Beach Gasfield & NAD 1927 & 60.39306 & -151.25000 & 10728 \\
\hline 34. K-Beach Bluff & “ & 60.47472 & -151.27722 & 7884 \\
\hline 35. Kasilof River & “ & 60.38333 & -151.28167 & 12051 \\
\hline 36. Coho Loop Bluff & “ & 60.29889 & -151.38139 & 11052 \\
\hline 37. Coal Creek South & “ & 60.33917 & -151.22750 & 11962 \\
\hline 38. Warren Ames Bridge & “ & 60.52500 & -151.20861 & 6631 \\
\hline 39. Kenai River Flats & “ & 60.54111 & -151.17833 & 10537 \\
\hline 40. Sterling Moosehorn Moraine & “" & 60.52306 & -150.67722 & 8724 \\
\hline 41. Chickaloon Bluff & “ & 60.98000 & -150.30306 & 12617 \\
\hline 42. Anchor Point North Fork Road & “ & 59.79500 & -151.79194 & 9881 \\
\hline 43. Homer Beach Munson Point & “ & 59.63500 & -151.51139 & 11873 \\
\hline 44. Funny River Horse Trail & WGS 1984 & 60.41543 & -150.90172 & 18877 \\
\hline 45. Swanson River Fen & “ & 60.78930 & -150.83183 & 13289 \\
\hline 46. Discovery Pond & “ & 60.78886 & -150.83372 & 13683 \\
\hline 47. Stone Steps Bluff & “ & 59.69646 & -151.30508 & 13683 \\
\hline
\end{tabular}


localities 14, 30, and 44; fig. 64). At these three sites peats accumulated in drainages that were either not glaciated during Naptowne time or were free of ice following the Moosehorn advance. All three localities would receive adequate moisture for peat growth even during dry periods. However, the main pulse of peat growth began at several sites that date between 13 and 14 cal kya, probably in depressions made available by the melting of buried stagnant glacial ice. Several basal peat ages cluster during the Younger Dryas, but the number is below earlier and later ages. A second recruitment peak occurred during the Holocene thermal maximum, implying that summer warming during the Holocene thermal maximum did not curtail peat accumulation, and, throughout their lengths, peat cores generally do not show obvious discontinuities or sharp vegetation changes that one might expect from forest advance, flooding, or wildfires. Instead, they reflect in general a consistently rising water table as the peat continuously accumulated on landforms as varied as kettles, glacial lake beds, uplifted glacioestuarine terraces, and outwash surfaces. One notable change very near the top of many peat cores is the sudden and unusual appearance of wood and shrub fragments in the peats, caused by invasion of peatlands by black spruce and shrubs since the 1970 s A.D.

\section{OTHER EVIDENCE OF CLIMATIC CHANGE}

Examination of black spruce invasion of peatlands near the Kenai airport (Marathon Road) and Kasilof (Coal Creek) (fig. 63, localities 31 and 7, respectively) and near Tear Drop Lake ${ }^{19}$ revealed initial forest recruitment beginning in earnest in the late 1800s A.D. after several millennia of peat accumulation (Berg, 2003) (fig. 65). A current study of shrub recruitment in 27 peat cores collected from Nikiski to Homer determined that shrubs first appeared in sphagnum peatlands only in the last three decades (Berg, 2005). These sites are being examined for changes in surface vegetation on aerial photographs taken in 1950 A.D., 1986 A.D., and 1996 A.D. (Kacy McDonnell, unpublished data) (fig. 66).

Late 20th century drying of western Kenai Peninsula lowland was first documented by Klein and others (2005), who compared the moisture/vegetation status of 1,113 random points on georeferenced aerial photographs from 1950 A.D. and 1996 A.D. A simple classification system, which identified wooded, open, wet, and water landscapes, revealed a strong trend toward a drier and more forested landscape (fig. 67). The study also inventoried 821 ponds and lakes in three study areas (Swanson River, Mystery Creek, and Tustumena

\footnotetext{
${ }^{19}$ Tear Drop Lake, which is informally named, is located $1.6 \mathrm{~km}(\sim 1$ mi) southeast of Browns Lake in the NW 1/4 of the Kenai B-2 NW Quadrangle (sheet 2).
}

Lake) and determined that $\sim 75$ percent of these water bodies showed some degree of shrinkage, with $\sim 40$ percent shrinking to $<50$ percent of their 1950 A.D. areas (fig. 68). The warmer summers of recent decades have apparently increased evapotranspiration in Kenai Peninsula lowland wetlands, even though annual precipitation records show no trends. Areas that were soggy sphagnum fens for as much as 18.0 cal ka have recently become dry enough during the summers to walk through without rubber boots. Indeed, these peatlands ('muskegs') are becoming shrublands and incipient black spruce forests with increasing recruitment of black spruce trees. As the black spruce forest matures and becomes more dense, wetlands that previously functioned as firebreaks will become fuel bridges between mixed forest uplands, promoting the spread of wildfires, especially in high wind circumstances.

To proceed to the next stop, return $0.3 \mathrm{~km}(0.2 \mathrm{mi})$ to Frontage Road, turn right (east) on Frontage Road and drive $0.16 \mathrm{~km}$ (0.1 mi) to Bridge Access Road. Turn right on Bridge Access Road and return to the traffic light at MP 16.4 of Kalifornsky Beach Road. Again turn right and proceed west on Kalifornsky Beach Road across the tread of the 15-m (49-ft) coastal terrace, which is underlain by $\sim 4 \mathrm{~m}(\sim 13 \mathrm{ft})$ of pebbly sand exposed in gravel pits on this surface (sheet 4). Lethe tephra is not found in sediments of this lower level of the Kalifornsky Glacioestuarine Terrace, which served as the base level for the ancestral lower Kenai River during the Skilak stade (fig. 35).

Strong storms generating large waves from western quadrants periodically attack this coastal terrace, cutting into the sand bank, removing the 0.6- to 1-m- (2- to 3-ft-) thick beach sand and gravel, and exposing the glacioestuarine diamicton beneath. To prevent erosion of shore properties and facilities, local residents have constructed a variety of protective structures, including timber walls tied together and anchored with cables, revetments of welded steel plates or interlocked spruce logs, concrete cylinders and blocks of armor rock (R.D. Reger, unpublished data). Damage from erosion is healed relatively quickly in the 15-m (49-ft) terrace bluff compared to the higher terrace surface farther south because sand exposed in the low scarp ravels quickly back to a stable angle and is soon colonized by grasses, like Lyme grass (Elymus arenarius), which prefer sandy substrates. For the next $8 \mathrm{~km}$ ( $5 \mathrm{mi}$ ) we will traverse this lower level of the Kalifornsky Glacioestuarine Terrace.

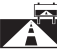

MP 11.4, Kalifornsky Beach Road. Drive up the gentle scarp onto the upper level of the Kalifornsky Glacioestuarine Terrace at $\sim 25 \mathrm{~m}(\sim 80 \mathrm{ft})$ elevation (Karlstrom, 1958). We will cross this surface for the next 10.7 km (6.7 mi). During late Moosehorn and Killey time, this terrace was carved into the back (west) 


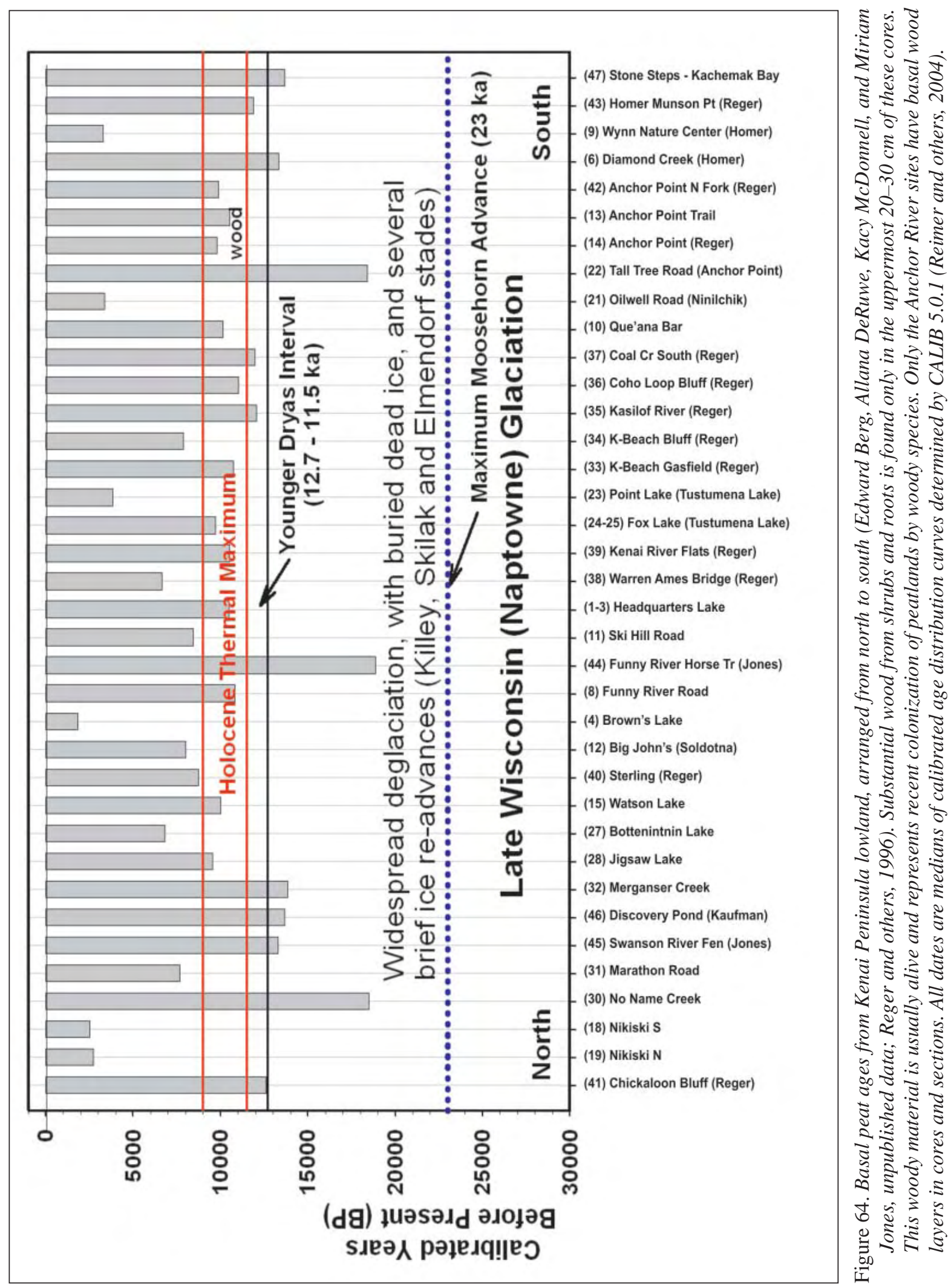


side of the Moosehorn terminal moraine to the east by rising waters of ancestral Cook Inlet (fig. 69, sheet 3). Deposits underlying the 25-m (80-ft) surface are exposed in the bluff for several miles along this segment of the coast. At MP 10.9, a short trail to the beach extends down a deep gully that was freshened when an unusual flood cut through the road fill in 1990 A.D. The gully walls and adjoining coastal bluff expose the two typical stratigraphic packages of the Bootlegger Cove Formation in the 25-m (80-ft) terrace (fig. 70). The lower, deep-inlet facies, which includes lenses of massive rainout diamicton, a laminated fine sand and clayey silt that comprises a mud drape, and thin-bedded and massive inlet-bottom sands, is much more variable than the correlative facies in the Kenai bluff. Calcareous plates of B. evermanni are much rarer here than at Kenai and are only slightly younger, 18.9 cal ka. Rare juvenile foraminifera in the thin-bedded rainout sand indicate a cold glacioestuarine environment with variable turbidity and salinity (Micropaleo Consultants, Inc., 1991 written commun.). The top of the deep-inlet facies is at $\sim+5-\mathrm{m}$ ( +16-ft) elevation.

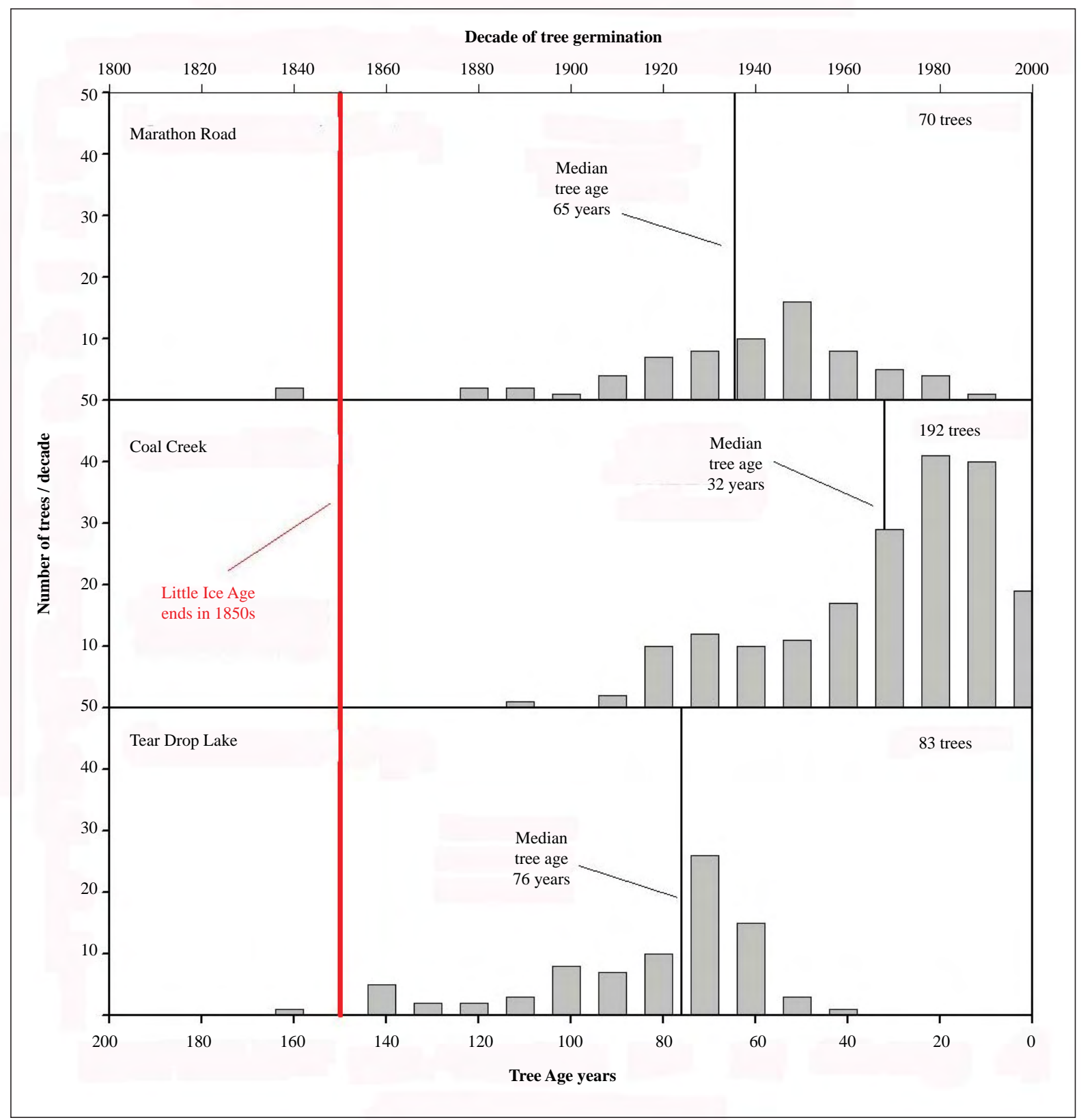

Figure 65. Histogram showing germination ages of young black spruce in wetlands in western Kenai Peninsula lowland (Berg, 2003). 


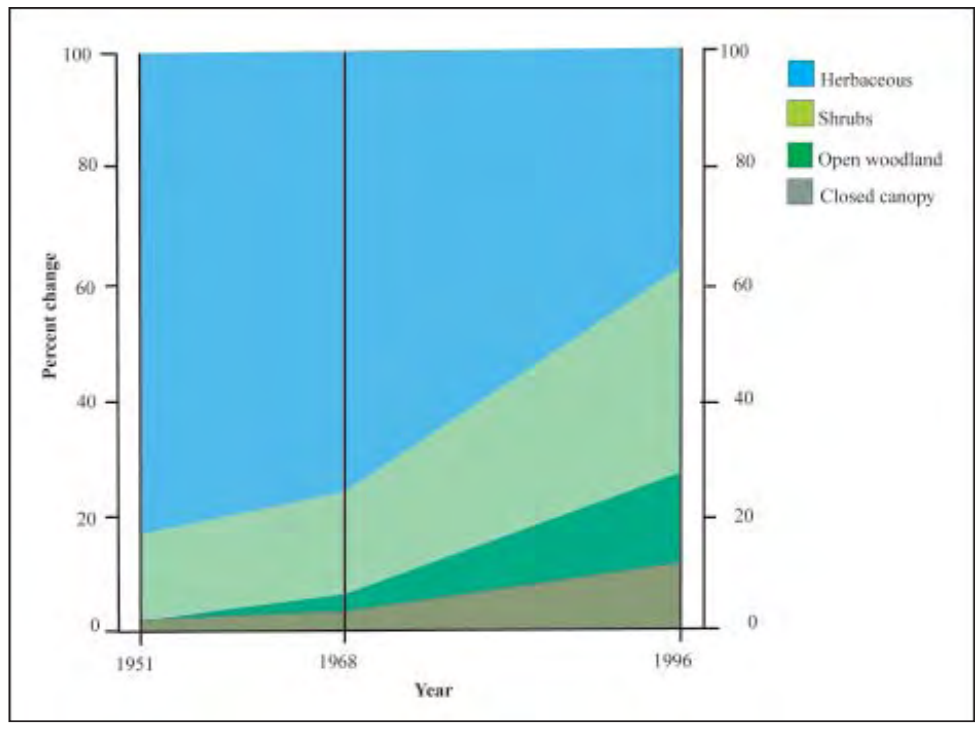

Figure 66. Changes in vegetation cover from 1950 A.D. through 1996 A.D. at Browns Lake, central Kenai Peninsula lowland (fig. 63, locality 4) (Kacy McDonnell, unpublished data).

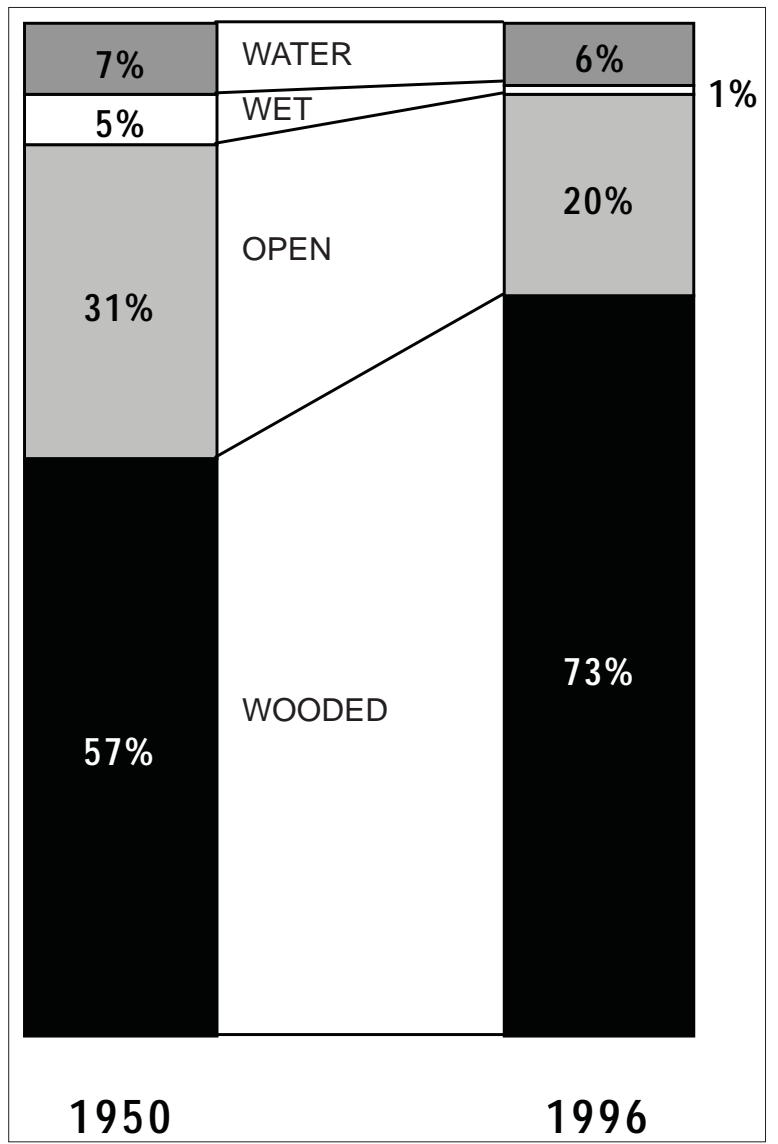

Figure 67. Changes of moisture/vegetation status at 1,113 random points in the Kenai Peninsula lowland as assessed on 1950 A.D. and 1996 A.D. aerial photographs (Klein and others, 2005).
The deep-inlet facies is abruptly overlain by a 12-m- (39-ft-) thick package of pebbly fine to very coarse sand with interbedded thin- to medium-bedded sandy pebble gravel (fig. 70). This package was deposited as the waters of ancestral Cook Inlet became progressively shallower due to rebounding of the inlet bottom. Typically the sediment package fines upsection and locally includes some volcanic ash and lapilli (R.D. Reger, unpublished data). As inlet waters shoaled, wave action and currents on the former inlet bottom transported and reworked these clastic sediments in the subtidal zone. At the top of the section a thin layer of clayey paludal or tidal silt with numerous roots of Equisetum is exposed below the surface peat, recording the emergence of the local surface into the intertidal zone from beneath the waters of ancestral Cook Inlet. The $7.2 \mathrm{RC}$ ka (8.0 cal ka) age of the lowermost surface peat is probably a distant-minimum age for the tidal sediments beneath.

AP 6.9, Kalifornsky Beach Road. Discussions with local residents and measurements made in 1975 A.D. and 30 years later indicate that average rates of recession of the high bluff of the Kalifornsky Glacioestuarine Terrace in this area vary from 0.2 to $\sim 0.5 \mathrm{~m}(0.6$ to $\sim 1.5 \mathrm{ft}$ ) per year (R.D. Reger, unpublished data). Attempts by residents to protect the high bluff from erosion include techniques as expensive as construction of gabions and low-revetment walls with cobbles in heavy wire mesh cages, which seem to effectively protect the base of the bluff, and measures as inexpensive and ineffective as piling old automobile bodies, tires, and tree debris along the base of the bluff and on the bluff face.

AP 4.7, Kalifornsky Beach Road. The 4-km (2.5-mi) public-access road to Kasilof Beach. Here at $\sim 25 \mathrm{~m} \mathrm{(} 80 \mathrm{ft})$ elevation is the transition from the tread of the Kalifornsky Glacioestuarine Terrace onto the Killey-age braid delta of the ancestral Kasilof River (sheet 3). The oldest peat known on Kalifornsky Glacioestuarine Terrace, which dates 9,410 \pm 225 RC yr B.P. $(10,688 \pm 225$ cal yr B.P.) (GX-10,782), was collected in this area by Rawlinson (1986, core SK34) from the base of a 3.6-m- (11.8-ft-) thick surface peat. For the next $7.5 \mathrm{~km}(4.7 \mathrm{mi})$ we will drive up this sandy braid delta, which becomes progressively coarser toward the outer of two Killey-stadial end moraines of the Tustumena Lake lobe. 


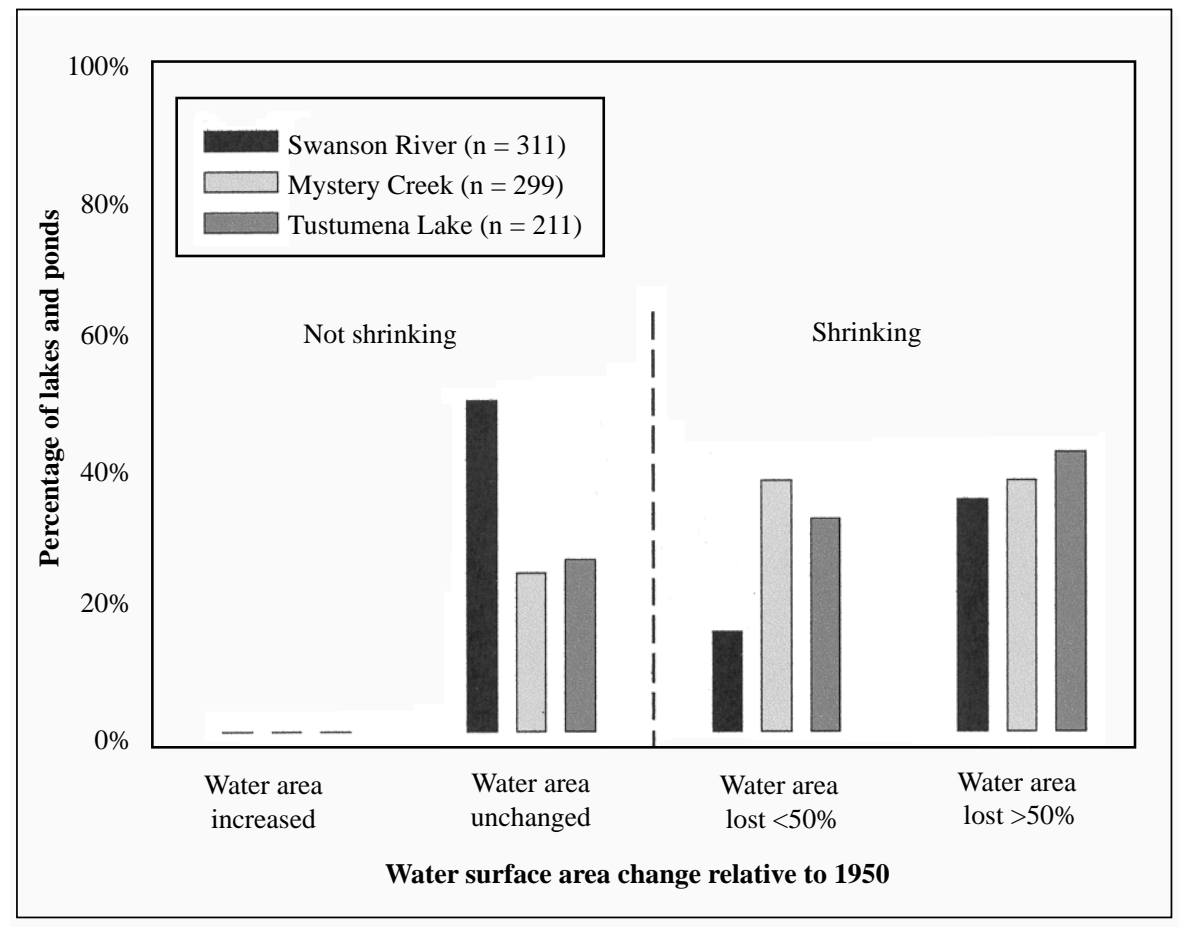

Figure 68. Spatial changes of water bodies from 1950 A.D. to 1996 A.D. in the Swanson River, Mystery Creek, and Tustumena Lake areas (Klein and others, 2005).

A MP 2.5, Kalifornsky Beach Road. Crossing of Coal Creek. This deeply incised and underfit stream is cut into braid-delta sands and gravels of late Moosehorn to Killey age. Although it follows a possible subglacial course, the modern westward course of lower Coal Creek probably initially developed when the Tustumena Lake lobe thinned and stagnated in latest Moosehorn time, opening the short topographic corridor through the hills east of the highway (sheet 5). Subsequently, proglacial drainage from north-lateral and terminal margins of the Tustumena Lake lobe flowed through this corridor and began building westward into a body of water, either freshwater or estuarine. Kettle lakes, just north of Coal Creek, formed when buried masses of dead ice melted. Lethe tephra is present in this area near the base of the loess blanket (Reger and others, 1996, fig. A59) and is present in sand dunes of late Killey age $2.7 \mathrm{~km}(1.7 \mathrm{mi})$ upstream near the crossing of Coal Creek by Sterling Highway (MP 106.6, McElroy Farm Avenue locality) (Reger and others, 1996, fig. A60).

MP 0.6, Kalifornsky Beach Road. Several kettle lakes pock the proximal part of the Killey braid delta built by proglacial streams draining the central terminal zone of the Tustumena Lake lobe.

MP 0, Kalifornsky Beach Road. Junction with Sterling Highway (MP 108.8). Turn right and proceed south along the Sterling Highway toward the Kasilof River.
MP 109.3, Sterling Highway. Crossing of the Kasilof River bridge. This turbid river is an important salmon stream that drains $1,919 \mathrm{~km}^{2}\left(\sim 738 \mathrm{mi}^{2}\right)$ of the westcentral Kenai Mountains and eastcentral Kenai Peninsula lowland (Curran and others, 2003). The river is subject to infrequent outburst flooding from several small lakes impounded by Tustumena Glacier (Childers, 1970; Post and Mayo, 1971). The lowest 8.3 km (5.2 mi) of the Kasilof River is estuarine, and stratigraphic evidence collected at $\sim-1 \mathrm{~m}(\sim-3 \mathrm{ft})$ elevation near the mouth of the Kasilof River (Combellick and Reger, 1994, borehole KS1) indicates that estuarine conditions commenced there between 8.5 and $12.3 \mathrm{cal} \mathrm{kya.}$

A sequence of interfingering rainout diamictons and rhythmites with rare cobbles is exposed in the lower $7 \mathrm{~m}$ (23 ft) of the river bluff near the mouth of the Kasilof River (Reger and others, 1996, locality KEN117). Two samples from low in the diamicton were submitted for microfossil analysis and determined to contain no marine or estuarine fossils. However, four freshwater diatoms were identified, including rare examples of Tetracyclus cf lacustris, Diatoma?, Pinnularia, and Melosira granulata (Micropaleo Consultants, Inc., 1993 written commun.), indicating that the environment of deposition was initially a deep, cold, meltwater lake. The top of the diamicton is at $+8 \mathrm{~m} \mathrm{(+26} \mathrm{ft)} \mathrm{elevation}$ (Reger and others, 1996, fig. A57). In sharp contact above is a 5-m- (16-ft-) thick medium to coarse sand, representing distal braid-delta deposits of Killey age. Above 


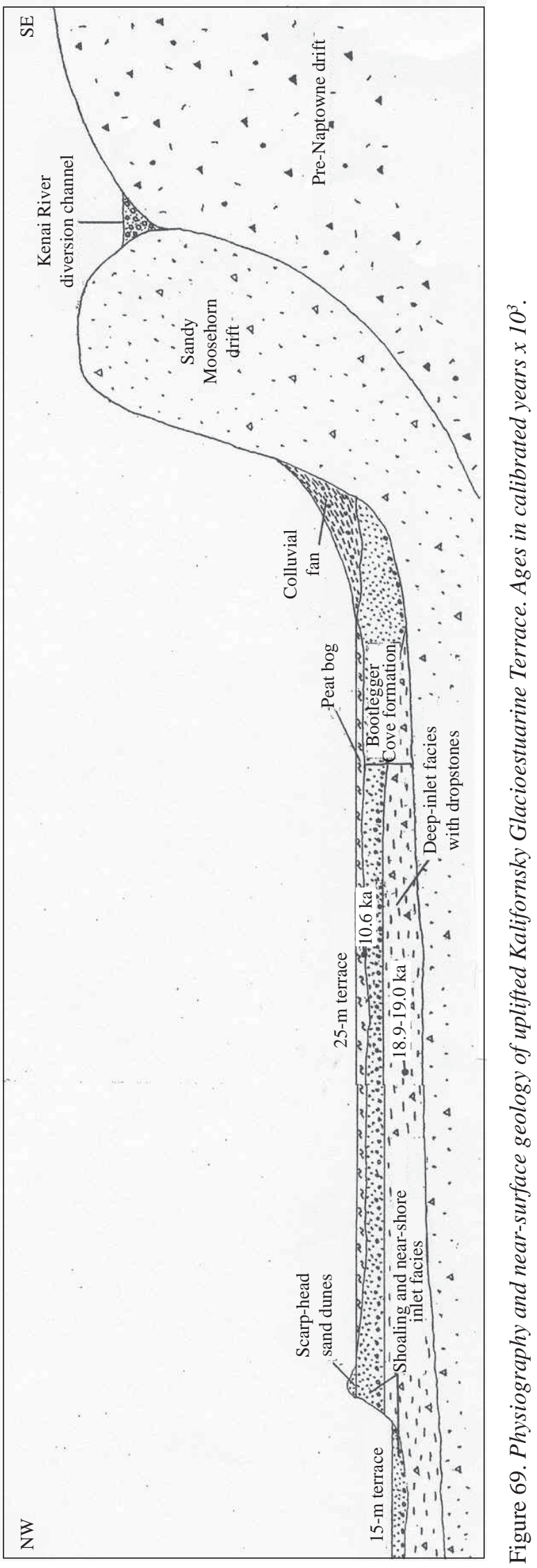




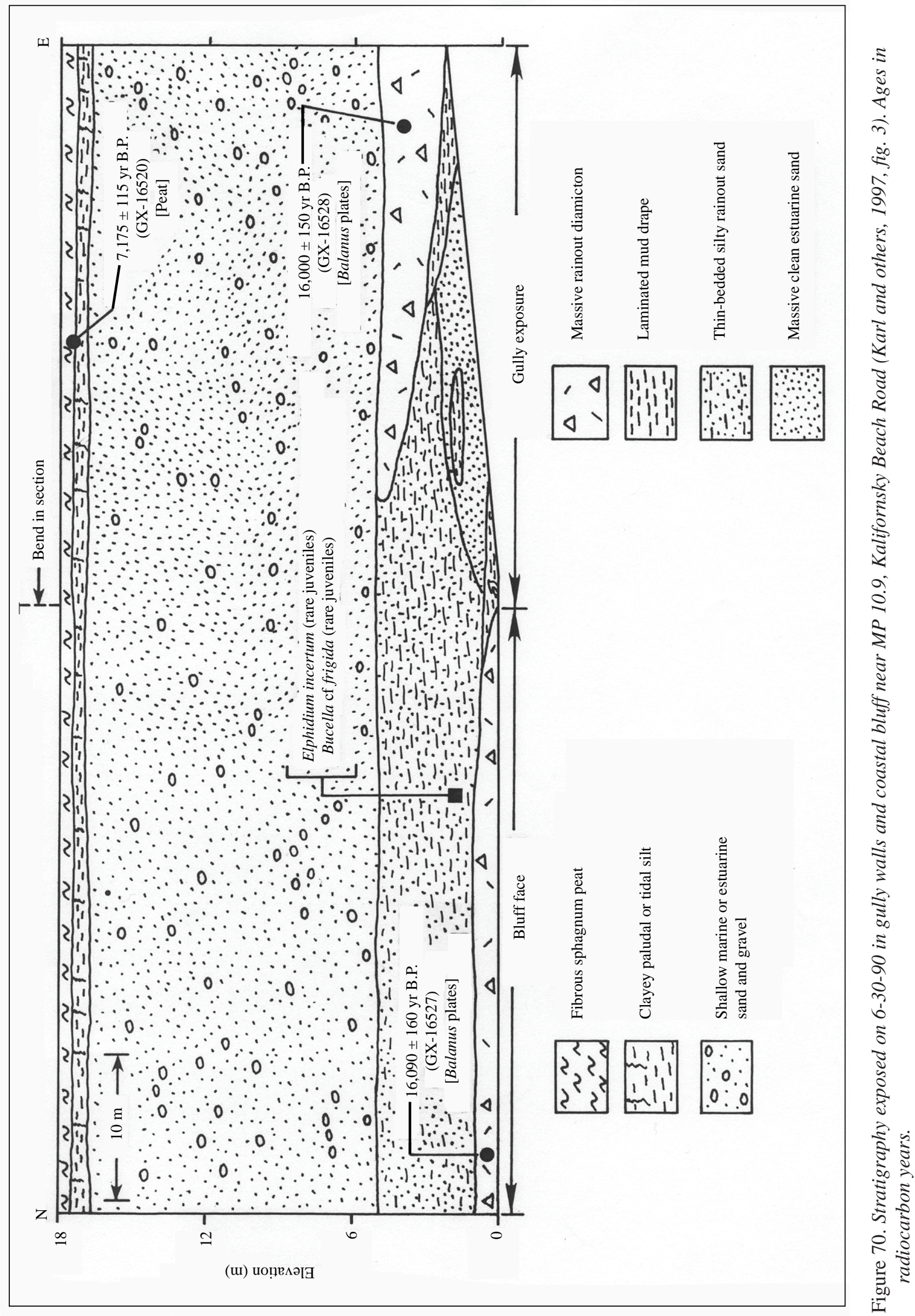


the distal sand are $2 \mathrm{~m}$ ( $6 \mathrm{ft})$ of gravel with numerous cobbles, representing proximal braid-delta outwash of Killey age. Beneath surface loess at the top of the section is a 25 -cm- (10-in-) thick layer of medium to coarse distal braid-delta sand containing Lethelike tephra mixed with at least one other volcanic ash, tephra 13 of Reger and others (1996). This section documents the formation of a deep meltwater lake in late Moosehorn time and subsequent growth into the lake or ancestral Cook Inlet of a braid delta of Killey age, an interpretation supported by landform relations (sheets 3 and 5). We suggest that detailed study of microfossils through this section may document the transition in the diamicton from the former meltwater lake to glacioestuarine conditions $\sim 18.9$ cal kya, as indicated by the glacioestuarine section in the Kalifornsky Glacioestuarine Terrace to the north.

A 109.5, Sterling Highway. Karlstrom (1958) reported an exposure of coal-bearing bedrock in the south bank of the Kasilof River at the bridge and suggested that Tertiary bedrock is fairly shallow in this area. Barnes and Cobb (1959, sheet 17) mapped Sterling Formation in coastal bluffs from the south to within $11 \mathrm{~km}$ (7 mi) of the mouth of the Kasilof River.

MP 109.7, Sterling Highway. Drive up onto the sand-dune-covered outwash terrace of Killey age from Tustumena Lake lobe, which we will cross for $1 \mathrm{~km}$ ( 0.6 mi) (sheets 3 and 5).

MP 110.8, Sterling Highway. Crossing of Crooked Creek. This underfit stream winds across a lengthy, wide, and complex paleo-drainage channel that ultimately heads on the northeastern flank of Caribou Hills to our southeast but also received water from two Killey-age end moraines of Tustumena Lake lobe (sheets 3 and 5$)^{20}$. The modern stream is incised 10 to $15 \mathrm{~m}$ (33 to $49 \mathrm{ft}$ ) below the Killey outwash apron emanating from the northwest terminal moraine of the Tustumena Lake lobe.

\section{STOP 8. NORTH COHOE LOOP GRAVEL PIT}

MP 111, Junction of North Cohoe Loop and Sterling Highway. Turn right (northwest) into the large gravel pit beside North Cohoe Loop for Stop 8.

We are at the apex of the extensive braid delta built northwestward into ancestral Cook Inlet by ancestral

\footnotetext{
${ }^{20}$ Lethe tephra has been identified on the outer moraine (Reger and others, 1996, fig. A68) but has not yet been found on the inner end moraine, indicating that the terminal moraine at least was present when the tephrafall occurred in late Killey time. Inside the inner end moraine, Lethe tephra lies directly on pebbly sand probably deposited in a meltwater lake (Reger and others, 1996, fig. A64), suggesting that the 70-m (230-ft) lake existed prior to the Skilak stade.
}

Crooked Creek during the Killey stade (sheets 3 and 5). This large gravel pit was created by removal of pitted outwash of Killey age. Pitting of the braid delta indicates that Killey outwash buried stagnant masses of late Moosehorn ice. The early advance of the Tustumena Lake lobe during the Killey stade impounded a meltwater lake $7.2 \mathrm{~km}(\sim 4.5 \mathrm{mi})$ up Crooked Creek between the Moosehorn terminal moraine and the Killey terminal moraine at a modern elevation of $\sim 95 \mathrm{~m}(\sim 312 \mathrm{ft})$ (sheet 5). Lake waters overtopped two divides at $\sim 95 \mathrm{~m}$ ( $\sim 312 \mathrm{ft}$ ) elevation (we suggest in response to differential melting of ice cores in Moosehorn moraine), producing a minor northward overflow (A in sheet 5), which was probably of short duration, and a major overflow (B in sheet 5) in the southwestern corner of the impounded lake, which entered the upper North Fork Ninilchik River. This lake received considerable meltwater from the large ice-marginal channel now occupied by upper Crooked Creek (sheet 5), and the resulting overflow further deepened the paleovalley occupied by the North Fork Ninilchik River. Later in the Killey stade, recession of the ice front drained the impounded lake, allowing the resumption of aggradation in middle and lower Crooked Creek with considerable input of material from the inner end moraine of the Tustumena Lake lobe.

At the end of the Killey stade, the Tustumena Lake lobe receded several miles and during the Skilak stade readvanced to a position $10 \mathrm{~km}(\sim 6 \mathrm{mi})$ behind the inner Killey end moraine (fig. 10). A large terminal lake initially formed between the ice front and the back side of the inner Killey end moraine probably late in the Killey stade, and, during the Skilak stade, wave action in this lake cut a prominent shoreline at $\sim 70 \mathrm{~m}(\sim 230 \mathrm{ft})$ modern elevation into the back (inner) side of the Killey end moraine (sheets 3 and 5). Areas inundated by the 70-m (230-ft) lake are now the settings of extensive swamps around the western end of Tustumena Lake. Physiographic features indicate that this extensive predecessor of Tustumena Lake had three different outlets at different times, perhaps in response to differential melting of morainal ice cores. The highest threshold (A in sheet 5) at $\sim 72 \mathrm{~m}(\sim 235 \mathrm{ft})$ elevation is $\sim 75 \mathrm{~m}(\sim 245 \mathrm{ft})$ wide and released former lake waters into ancestral Crooked Creek. A second gap (B in sheet 5) is located at $\sim 57 \mathrm{~m}$ ( $\sim 190 \mathrm{ft}$ ) elevation, measures $\sim 150 \mathrm{~m}(\sim 500 \mathrm{ft})$ wide, and channeled lake waters into the ancestral Kasilof River. A third outlet ( $\mathbf{C}$ in sheet 5 ) was of unknown dimensions and elevation in the vicinity of the present course of the Kasilof River. Post-Skilak incision by the Kasilof River along this course has lowered the level of modern Tustumena Lake to $36 \mathrm{~m}(\sim 120 \mathrm{ft})$ elevation. A prominent undated shoreline at $\sim 40 \mathrm{~m}(\sim 130 \mathrm{ft})$ elevation along the southwestern shore of Tustumena Lake documents a lake level $\sim 4 \mathrm{~m}(\sim 13 \mathrm{ft})$ above the modern level. 
The outermost end moraine associated with the modern terminus of Tustumena Glacier, which drains Harding Icefield, was assigned an age of probable late Wisconsin by Wiles and Calkin (1994, table 1) on the basis of its distance from and large size compared to nearby Little Ice Age moraines, a 1-m- (3.3-ft-) thick weathering profile, 2-cm- (0.8-in-) thick weathering rinds on granitic till stones, and a 1.8-m- (5.9-ft-) thick cover of loess, tephra, and eolian sand, which dates 3,760 \pm 100 RC yr B.P. $(4,135 \pm 100$ ca. yr B.P.) (Beta-33,344) near the center of the section (Wiles and Calkin, 1992, p. 117-121) (fig. 71). The youngest of two Little Ice Age end moraines buries a mature forest of spruce, birch, and alders dated by Karlstrom (1964, table 3) at $400 \pm 150$ RC yr (410 $\pm 150 \mathrm{cal}$ yr B.P.) (L-117K), providing a maximum-limiting age for the Tunnel II advance. Spruce trees growing on the nearby Tunnel I moraine date from 1864 A.D., establishing a distant-minimum age for that advance. Aerial photographs indicate that most of the terminal lake formed after 1950 A.D.

This last stop north of Clam Gulch is a good place to summarize events and features we have studied so far along the west coast of the Kenai Peninsula lowland because from Clam Gulch south we will be looking at very different terrain. Table 5 correlates the stratigraphy and summarizes the implications of the various geologic units in areas that were glaciated during the Naptowne glaciation. The top of the Sterling Formation of Pliocene age is deepest in the Kenai area, becomes shallower north toward Nikiski, and becomes shallower toward the south. South of the Kasilof River, the Sterling Formation is very close to the surface or is exposed in coastal bluffs. We have mentioned the probable existence of a meltwater lake of regional proportions dammed in the early Moosehorn stade by ice across the mouth of Cook Inlet, and we have discussed sandy glacial deposits scoured up from the bottom of this lake and scoured from sandstones of Tertiary age as glaciers from the north and northwest converged on the Kenai Peninsula lowland. With thinning and retreat of glaciers following the climax of the Moosehorn advance and the worldwide rise of eustatic sea level, marine waters broke through the ice barrier across the southern inlet and flowed northward as far as Kenai by 19.2 cal kya. Mixing of fresh meltwater and salt water produced the estuarine conditions that existed then and still exist in Cook Inlet today. Near the end of the Moosehorn stade a variety of sediments related to tidewater glaciers and tabular ice shelves was deposited in deep glacioestuarine circumstances, although the bottom of ancestral Cook Inlet was rebounding after being relieved of the mass of Moosehorn glaciers. In the Cohoe area, freshwater deposits document the presence of a local meltwater lake in late Moosehorn time. We suggest that a freshwater lake could exist there during late Moosehorn time before invasion by marine waters.

By the Killey stade, the nearshore rebounding inlet bottom came under the influence of bottom wave effects and currents, and we see the effects of shoaling on sediments in the upper exposures of coastal bluffs. In the Nikiski area, coarse outwash was deposited on emergent land in the proximal zone of a broad braidplain that extended clear to Kenai. In the south, braid deltas buried stagnant masses of late Moosehorn ice and spread into ancestral Cook Inlet. Lethe tephra was deposited

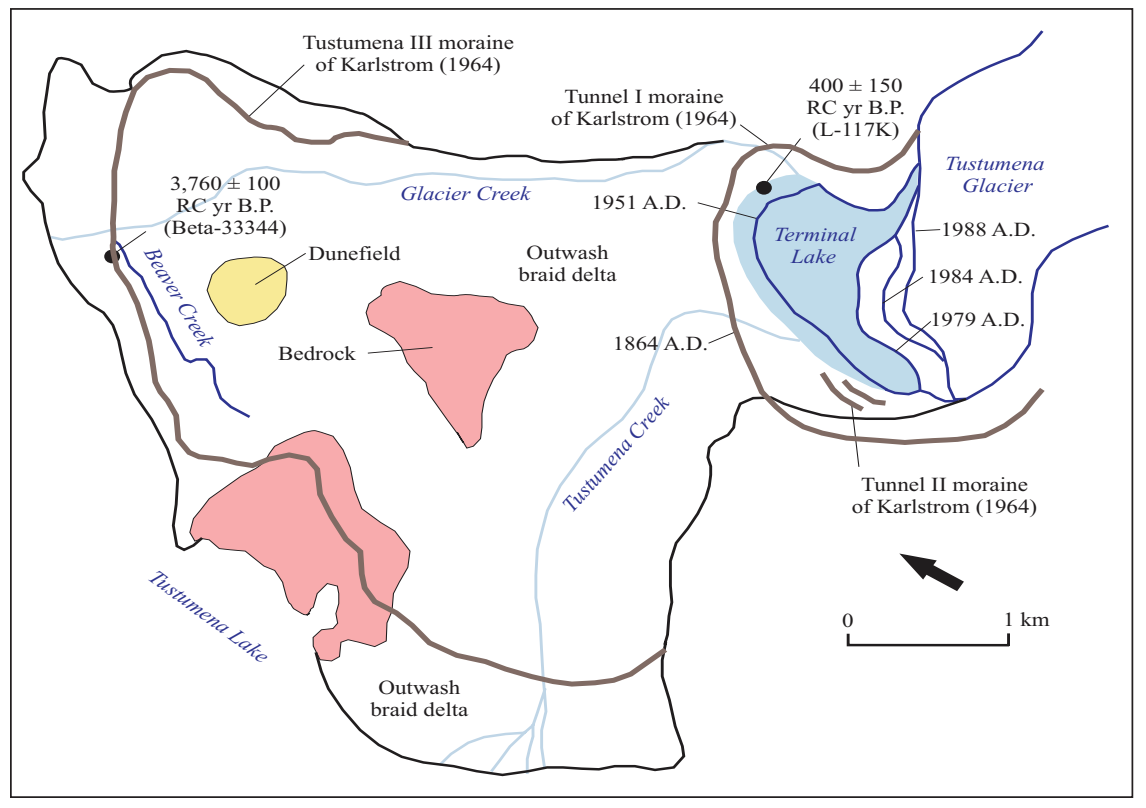

Figure 71. Terminal area of Tustumena Glacier, showing physiography and ages of moraines (modified from Wiles and Calkin, 1994, fig. 10). 
Table 5. Correlation and implications of stratigraphy along west coast of Kenai Peninsula lowland north of Clam Gulch

\begin{tabular}{|c|c|c|c|c|c|}
\hline Age & Nikiski & Kenai & Kalifornsky & Kasilof & Cohoe \\
\hline 要 & Loess & Loess & $\begin{array}{l}\text { Peat, loess, and } \\
\text { tidal muds } \\
\text { [7.2 RC ka] }\end{array}$ & Loess & Loess \\
\hline 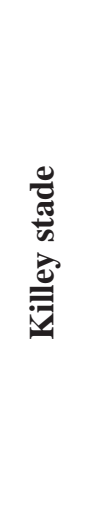 & $\begin{array}{c}\text { Lethe tephra } \\
\text { Pitted proximal } \\
\text { outwash } \\
\text { (emergent) } \\
\text { Proximal } \\
\text { outwash } \\
\text { (emergent) and } \\
\text { subestuarine } \\
\text { pebble gravels w/ } \\
\text { moraine-bank } \\
\text { complexes } \\
\text { (shoaling inlet) }\end{array}$ & $\begin{array}{l}\text { Lethe tephra } \\
\\
\text { Distal } \\
\text { glacioestuarine } \\
\text { braidplain sands w/ } \\
\text { numerous pebbles } \\
\text { (shallow inlet) }\end{array}$ & $\begin{array}{l}\text { Subestuarine } \\
\text { bottom sands and } \\
\text { pebble gravels } \\
\text { (shoaling inlet) }\end{array}$ & $\begin{array}{l}\text { Lethe tephra } \\
\text { Prograding pitted } \\
\text { braid delta from } \\
\text { Tustumena Lake } \\
\text { lobe (shallow inlet) }\end{array}$ & $\begin{array}{l}\text { Lethelike tephra } \\
\\
\text { Prograding pitted } \\
\text { braid delta from } \\
\text { Tustumena Lake } \\
\text { lobe (shallow inlet) }\end{array}$ \\
\hline \multirow[t]{3}{*}{ 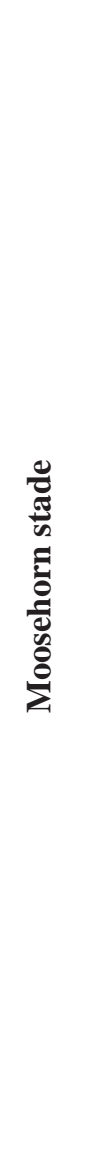 } & $\begin{array}{l}\text { Rainout complex } \\
\text { w/ numerous } \\
\text { dropstones } \\
\text { associated w/ } \\
\text { tabular ice } \\
\text { shelves } \\
\text { (shallowing inlet) }\end{array}$ & $\begin{array}{l}\text { Rainout diamicton } \\
\text { and numerous } \\
\text { dropstones } \\
\text { associated w/ } \\
\text { tabular ice shelves } \\
\text { that deform inlet- } \\
\text { bottom sediments } \\
\text { toward SE during } \\
\text { low tides } \\
\text { (shallowing inlet) } \\
\\
\text { Sandy distal } \\
\text { subestuarine fan } \\
\text { and rainout } \\
\text { deposits w/ } \\
\text { numerous } \\
\text { dropstones and } \\
\text { barnacle plates } \\
\text { [19.2 cal ka] } \\
\text { (deep inlet) }\end{array}$ & $\begin{array}{l}\text { Glacioestuarine } \\
\text { inlet-bottom } \\
\text { complex w/ } \\
\text { barnacle plates and } \\
\text { rare juvenile } \\
\text { foraminifera } \\
\text { [18.9 cal ka] } \\
\text { (deep inlet) }\end{array}$ & $\begin{array}{l}\text { Glacioestuarine } \\
\text { inlet-bottom } \\
\text { complex } \\
\text { (deep inlet) }\end{array}$ & $\begin{array}{l}\text { Glaciolacustrine } \\
\text { rainout diamicton } \\
\text { and rhythmites w/ } \\
\text { rare freshwater } \\
\text { diatoms and } \\
\text { dropstones } \\
\text { (cold meltwater } \\
\text { lake) }\end{array}$ \\
\hline & $\begin{array}{c}\text { Glacial till } \\
\text { (glaciation from } \\
\text { NW) } \\
\text { (subsurface) }\end{array}$ & $\begin{array}{c}\text { Glacial till } \\
\text { (glaciation from } \\
\text { NW) } \\
\text { (subsurface) }\end{array}$ & $\begin{array}{c}\text { Glacial till } \\
\text { (glaciation from } \\
\text { NW) } \\
\text { (subsurface) }\end{array}$ & $\begin{array}{c}\text { Glacial till } \\
\text { (glaciation from } \\
\text { NW and SE) } \\
\text { (subsurface) }\end{array}$ & $\begin{array}{l}\text { Glacial till } \\
\text { (glaciation from } \\
\text { NW and SE) } \\
\text { (subsurface) }\end{array}$ \\
\hline & $\begin{array}{l}\text { Fined-grained } \\
\text { glaciolacustrine } \\
\text { complex } \\
\text { (deep meltwater } \\
\text { lake) } \\
\text { (subsurface) }\end{array}$ & $\begin{array}{c}\text { Fined-grained } \\
\text { glaciolacustrine } \\
\text { complex } \\
\text { (deep meltwater } \\
\text { lake) } \\
\text { (subsurface) }\end{array}$ & $\begin{array}{c}\text { Fined-grained } \\
\text { glaciolacustrine } \\
\text { complex } \\
\text { (deep meltwater } \\
\text { lake) } \\
\text { (subsurface) }\end{array}$ & $\begin{array}{l}\text { Fined-grained } \\
\text { glaciolacustrine } \\
\text { complex } \\
\text { (deep meltwater } \\
\text { lake) } \\
\text { (subsurface) }\end{array}$ & $\begin{array}{l}\text { Fined-grained } \\
\text { glaciolacustrine } \\
\text { complex } \\
\text { (deep meltwater } \\
\text { lake) } \\
\text { (subsurface) }\end{array}$ \\
\hline 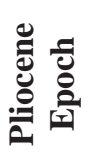 & $\begin{array}{l}\text { Sterling } \\
\text { Formation } \\
\text { (subsurface } \\
\text { bedrock) }\end{array}$ & $\begin{array}{l}\text { Sterling Formation } \\
\text { (subsurface } \\
\text { bedrock) }\end{array}$ & $\begin{array}{l}\text { Sterling Formation } \\
\text { (subsurface } \\
\text { bedrock) }\end{array}$ & $\begin{array}{l}\text { Sterling Formation } \\
\text { (shallow bedrock) }\end{array}$ & $\begin{array}{l}\text { Sterling Formation } \\
\text { (shallow bedrock) }\end{array}$ \\
\hline
\end{tabular}


from one or more northeast-moving ash-rich plumes that passed across the western and central Kenai Peninsula lowland in late Killey time, seemingly providing a temporal reference that allows correlation of landforms and deposits regionally. This distinctive and complex tephra was then buried by post-Killey loess and eolian sand.

MP 112.1, Sterling Highway. Virginia Lake (not labeled in sheets 3 or 5) was impounded against drift of Moosehorn age in a late Moosehorn drainage channel by growth of a gravel alluvial fan of Killey age that was deposited by ancestral Crooked Creek. For the next $4 \mathrm{~km}$ ( 2.5 mi) we will parallel this large drainageway as we drive along the base of moraine deposited during the Moosehorn maximum by the Tustumena Lake lobe. This former drainage course obviously postdates the Moosehorn maximum and predates the Killey stade. Physiographic evidence indicates that in late Moosehorn time, early in the development of the braid delta in the Cohoe area, this channel carried water from a meltwater lake in the northern Clam Gulch lowland northeastward into the meltwater lake that formerly existed at the present mouth of the Kasilof River (refer to discussion for MP 109.3).

MP 114.6, Sterling Highway. Crossing of the 0.5-km- 0.3-mi-) wide, peat-clogged paleo-channel of late Moosehorn age that drained a meltwater lake in the vicinity of Clam Gulch. Shoreline features of this meltwater lake are present at a modern elevation of $\sim 65$ $\mathrm{m}(\sim 215 \mathrm{ft})$, and the outlet of the former lake is $1.6 \mathrm{~km}$ ( 1 mi) north of Stop 9 (sheet 5).

MP 116, Sterling Highway. Drop down onto the former floor of an arm of a meltwater lake with shoreline features preserved at $\sim 80 \mathrm{~m}(\sim 260 \mathrm{ft})$ elevation. We will discuss this lake and other meltwater lakes at Stop 9.

MP 116.8, Sterling Highway. Drive up across wave-notched shoreline of 80-m ( 260-ft) lake and through sandy Moosehorn-age terminal moraine of Tustumena Lake lobe.

\section{STOP 9. CLAM GULCH}

MP 117.2, Sterling Highway. Turn left (southeast) into parking area for Stop 9.

We are standing on the outer, southwestern flank of the Moosehorn terminal moraine of the Tustumena Lake lobe on a wavecut notch of a former meltwater lake at $\sim 80$-m ( 260-ft) modern elevation (sheet 5). The Sterling Highway continues southwestward down into a former paleodrainage channel that was occupied by this lake and predecessor meltwater lakes in the southern Kenai Peninsula lowland between this terminal moraine and a corresponding terminal moraine of the Kachemak
Bay lobe $58 \mathrm{~km}$ ( $36 \mathrm{mi})$ to the southwest. The terrain we will be traversing is much different than the terrain we have crossed until now, which was glaciated during the last major ice age. Landforms clearly show that the southern Kenai Peninsula lowland was scoured by thick glacial ice during a pre-Naptowne glaciation, probably early Wisconsinan in age, when the Cook Inlet trough was completely filled with ice that extended past Kodiak Island to the edge of the continental shelf in the North Pacific Ocean (Coulter and others, 1965). Recent mapping indicates that the Caribou Hills barely stood above the level of the penultimate glaciation, although they had been overridden by a pre-Wisconsin glaciation (R.D. Reger, unpublished data). In the lowland west of the Caribou Hills, subglacial till was molded into flutes parallel to the axis of the Cook Inlet trough (fig. 72A). During the subsequent nonglacial interval, the surface drainage was initially controlled by the flutes and grooves, producing a trellis drainage system (fig. 72B). Integration of this trellis system was interrupted during the Moosehorn advance when the southern Kenai Peninsula lowland was inundated by a large meltwater lake impounded between the Caribou Hills and the massive compound ice sheet that advanced eastward from the west side of Cook Inlet (fig. 8), and pre-existing stream valleys were flooded (fig. 72C). As lake levels lowered when the glacier dam thinned after the climax of the Moosehorn stade and the impounded lake drained at the end of the stade, braided and meandering streams in the southern Kenai Peninsula lowland wandered back and forth across the lake bottom, cutting into their beds in response to isostatic rebound and retreat of coastal bluffs. In the process, a modified trellis pattern has begun to develop by lengthening of tributaries, deepening of paleovalleys and main stream channels, and piracy (fig. 72D). Large streams, like the Ninilchik River, Deep Creek, and the Anchor River, have cut down through lake deposits and glacial drift, which are fairly thick in some paleovalleys (Nelson and Johnson, 1981; Reger and Petrik, 1993; Coble and W.J. Nelson and Associates, 1998), and have eroded into Tertiary bedrock, where bedrock structures control stream orientation.

Evidence for five prominent former lake levels at $\sim 125 \mathrm{~m}(\sim 410 \mathrm{ft}), \sim 110 \mathrm{~m}(\sim 360 \mathrm{ft}), \sim 100 \mathrm{~m}(\sim 330 \mathrm{ft})$, $\sim 80 \mathrm{~m}(\sim 260 \mathrm{ft})$, and $\sim 65 \mathrm{~m}(\sim 215 \mathrm{ft})$ modern elevations in the southern Kenai Peninsula lowland includes wavenotched and wave-modified moraines and hanging deltas (fig. 76C, sheets 5 and 6). However, numerous subtle shoreline features at intermediate elevations are also present. Shoreline features are generally discontinuous and correlations may be locally uncertain because of erosion by post-lake streams. Many obvious scarps are stream cut, not wave cut, and separating the two origins requires study of associated deposits. Physiographic 
evidence indicates that the $125-\mathrm{m}$ ( $\sim 410-\mathrm{ft})$ shoreline is climax Moosehorn in age, the 110-m (360-ft) and 100-m (330-ft) shorelines are intermediate in age, and the $80-\mathrm{m}$ (260-ft) and 65-m (215-ft) shorelines are late Moosehorn in age (fig. 73). Evidence on 1:25,000-scale topographic maps with 5 -m $(\sim 16-\mathrm{ft})$ contour intervals indicates that the 125-m ( 410-ft) shoreline may be tilted upward up to $15 \mathrm{~m} \mathrm{(} \mathrm{50} \mathrm{ft)} \mathrm{in} \mathrm{the} \mathrm{northern} \mathrm{lowland} \mathrm{compared} \mathrm{to}$ the southern lowland, but reliable age control is lacking. Evidence for a possible shoreline at $\sim 150 \mathrm{~m}(\sim 490 \mathrm{ft})$ elevation, including notched and possibly wave-modified ridge crests, is present in the southeastern quarter of the Clam Gulch-Anchor River lowland. These and other features above 125-m ( 410-ft) elevation along the western flank of the Caribou Hills generally mimic lower shorelines but they may be kame terraces of late early
Wisconsinan age. In that case, the gentle southward slope of these features and associated abandoned meltwater channels would reflect the general gradient of the former glacier surface and not former lake levels.

In contrast to the north flank of the Tustumena Lake lobe, there is no obvious terminal moraine between our location and the valley of the upper North Fork Ninilchik River to the southeast (sheet 5), and we suggest that, at the Moosehorn maximum, the southwestern flank of the Tustumena Lake lobe floated as a bulge into the 125-m ( 410-ft) lake. Fragments of the former terminal bulge are preserved as scattered hills of drift with slightly greater relief than nearby wave-modified, subdued hills of early Wisconsin drift and are surrounded by an extensive peatland.

WNW

A. Formation of ridges and swales during troughwide Early Wisconsin glaciation

Glacial ice

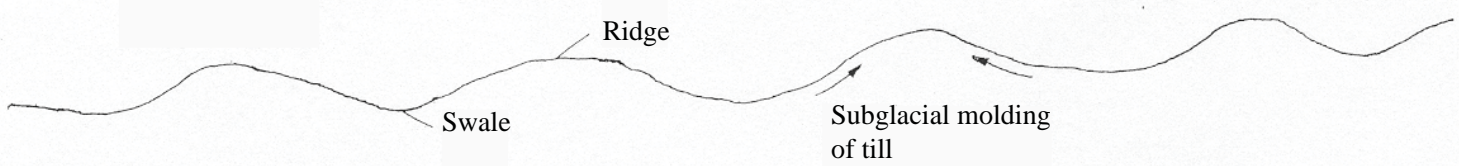

B. Trellis drainage initially develops during

Mid-Wisconsinan nonglacial interval

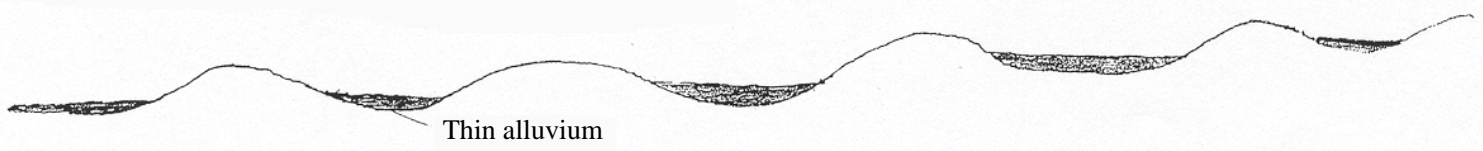

C. Extensive ice-impounded coldwater lake develops during Moosehorn stade

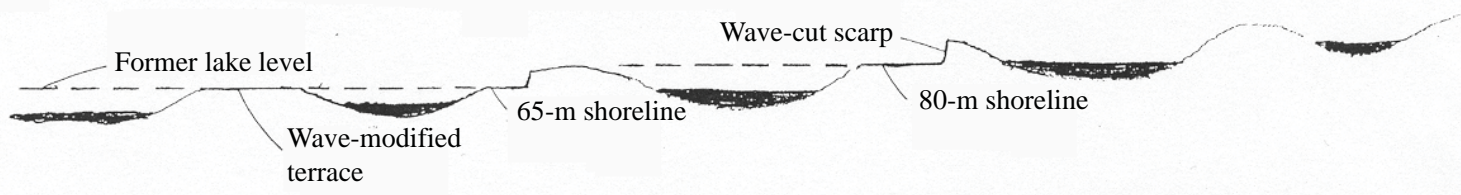

D. Postglacial streams incise trellis drainage

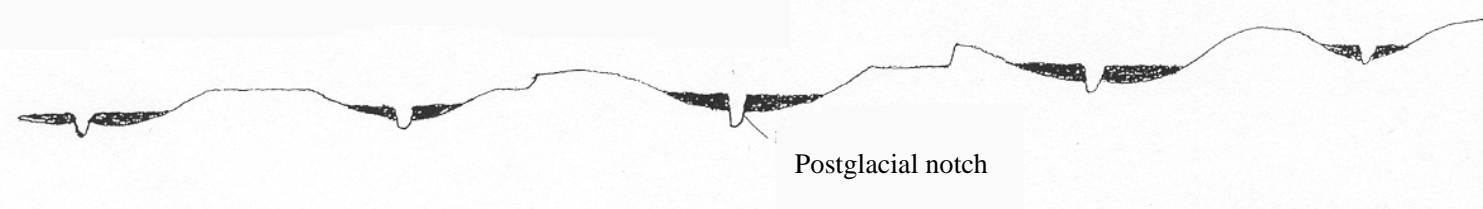

Figure 72. Evolution of topography in southern Kenai Peninsula lowland. 


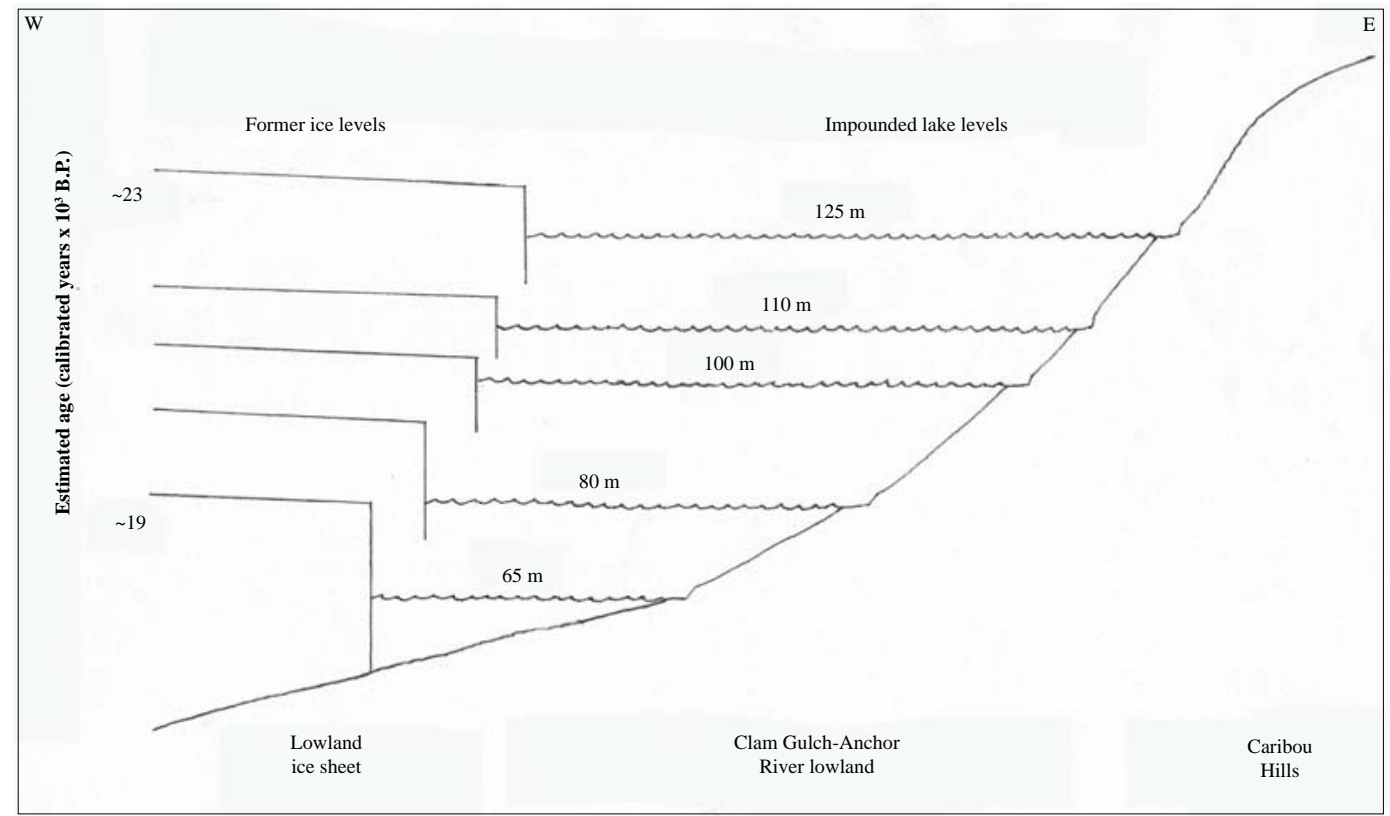

Figure 73. Glacier-impounded lakes in Clam Gulch-Anchor River lowland, southern Kenai Peninsula lowland.

\begin{abstract}
AP 117.3, Sterling Highway. Public access road to Clam Gulch beach, an optional site to visit to see large block and boulder erratics of igneous and metamorphic rock that were left here as a lag by erosion of the thin early Wisconsin drift that overlies the Sterling Formation. The Sterling Formation is described by Barnes and Cobb (1959) and Karl and others (1997b, p. 107). Excavations of an archeological site in this area (KEN-045) exposed a rich faunal assemblage consisting of marine and terrestrial remains. Dating of the site indicates it was probably occupied by Denaina speakers 0.3 to 0.4 RC kya (0.4 to 0.3 cal kya) (Reger, 1987), at a time when the local marine fauna was more representative of clear marine waters of the lower inlet than the turbid waters that are present at Clam Gulch today (D.R., 5/20/07, pers. commun.). Hearth remains in the site indicate that considerable coal was burned, requiring special care in dating the site.
\end{abstract}

MP 118.2, Sterling Highway. Settlement of Clam Gulch.

MP 121.l, Sterling Highway. Crossing of Falls Creek that, like nearby Corea Creek and several other small streams, drains directly into Cook Inlet. These small tributary streams have less discharge and less capacity for erosion than larger primary streams but have begun to steepen their lower courses in response to changes in base levels caused by isostatic rebound and rapidly retreating coastal bluffs. Although most small streams manage to develop short canyon rapids in their steep lower profiles, Falls Creek passes over a resistant coal bed and down a waterfall to the beach. Above this steep nickpoint, Falls Creek flows on a very gentle gradient across the floor of the $65-\mathrm{m}$ (213-ft) lake. About $1.6 \mathrm{~km}$ (1 mi) up Falls Creek to the east is a hanging delta along the shoreline of the $80-\mathrm{m}$ ( 260-ft) lake (sheet 5).

MP 122.6, Sterling Highway. Crossing of Corea Creek, which like Falls Creek, is very underfit for the pre-Moosehorn stream valley it occupies. This pre-Naptowne drainageway was flooded during the Moosehorn stade and formed an arm of the 80-m ( 260-ft) lake (sheet 5).

7) 125.1 Sterling Highway. The wide bench below (west) of Sterling Highway is associated with a shoreline cut at $\sim 65-\mathrm{m}(\sim 215-\mathrm{ft})$ elevation. For the next $2.3 \mathrm{~km}(\sim 1.4 \mathrm{mi})$ we will drive along the top of the wavecut scarp.

AP 129.5, Sterling Highway. This gully and other gullies in the next $0.8 \mathrm{~km}(\sim 0.5 \mathrm{mi})$ grade westward to $\sim 215$-ft (65-m) shoreline.

MP 135.1, Sterling Highway. Crossing of Ninilchik River bridge. Ninilchik River, now very underfit, follows a deeply incised, fairly narrow paleovalley southwest from its headwaters in a large swamp at the site of the 95-m ( 310-ft) meltwater lake impounded by the advance of Tustumena Lake lobe during the early Killey stade (sheet 5). The southwest-trending, 
slightly meandering upper valley of the Ninilchik River follows the general trellis pattern inherited from the preNaptowne glaciation of the Clam Gulch-Anchor River lowland and is likely a paleodrainage feature of preNaptowne age that was further deepened in early Killey time by overflow from the impounded lake. About 4.5 $\mathrm{km}$ (2.8 $\mathrm{mi}$ ) above the river mouth, the valley abruptly turns northwest and heads directly for Cook Inlet. This right-angle turn and the straight trend of the terminal reach of the Ninilchik River are almost certainly controlled by a system of generally northwest-striking, near-vertical faults in the Tertiary bedrock. The lower valley is cut $>15 \mathrm{~m}$ (>50 ft) into the Sterling Formation, which is discontinuously exposed in the valley walls as far as $7.4 \mathrm{~km}(\sim 4.6 \mathrm{mi})$ upstream from the mouth of the river (Barnes and Cobb, 1959).

MP 135.3, Sterling Highway. Onto gravel floor of paleochannel probably of the ancestral Ninilchik River formed at $\sim 45-\mathrm{m}(\sim 150-\mathrm{ft})$ elevation as it wandered across the former lake bottom during post-lake drainage adjustments. A correlative bench can be seen to the northwest across the valley of the lower Ninilchik River above the lower village. For the next $1.4 \mathrm{~km}(\sim 0.9 \mathrm{mi})$ we will drive across this surface through upper Ninilchik village.

A MP 136.6, Sterling Highway. Crossing of Deep Creek bridge, which was badly damaged by the exceptionally large flood of 2002 A.D. The former stream was considerably altered by that event, during which floodplain trees were undercut and piled into large drift piles, channels and pools were filled with plant and sediment debris and straightened, many debris flows and slides were initiated by saturation of colluvial aprons on steep bedrock walls, and a large gravel delta was built into Cook Inlet.

Deeply incised, straight reaches of Deep Creek trend generally northwest and are sharply separated by shorter straight reaches that generally trend east-west. Evidence in the Caribou Hills indicates that the straight northwest-trending reaches follow a system of parallel bedrock faults. The deep valley of lower Deep Creek is wider than the lower valley of the Ninilchik River and is deeply cut into Tertiary bedrock (Barnes and Cobb, 1959, sheet 17). Stream terraces on opposite sides of Deep Creek do not match in elevation and have crosssloping treads, indicating, along with the relatively wide valley, that Deep Creek meandered back and forth across its valley during incision.

Distribution of moraines, ice-marginal meltwater channels, and outwash terraces indicate that ice from the Kenai Mountains entered the upper Deep Creek drainage during middle and late stades of the early Wisconsin glaciation (R.D. Reger, unpublished data). Ice of the
Naptowne glaciation scoured the northeastern flank of the Caribou Hills up to an elevation of $545 \mathrm{~m}(\sim 1,800 \mathrm{ft})$ but did not enter the headwaters of the North Fork Deep Creek.

MP 137, Sterling Highway. View northwest of mouth of Deep Creek. Smoke from burning subterranean coal beds has been visible at times emanating from the exposure below the lighthouse.

MP 137.2, Sterling Highway. The roadcut to the left (southeast) exposes sandy lake-bottom sediments of the 80-m ( 260-ft) lake. For the next $3.8 \mathrm{~km}(\sim 2.4 \mathrm{mi})$, the Sterling Highway climbs up a gully cut along the maximum limit of ice of Moosehorn age from the west side of Cook Inlet.

MP 138.6, Sterling Highway. Begin descent into drainage of Clam Creek. South-trending ridges on the west side of the Sterling Highway ahead are remnants of terminal moraines of Moosehorn age deposited by ice from across Cook Inlet. The lower $4 \mathrm{~km}$ ( 2.5 mi) of ancestral Clam Creek were diverted to the south by this advance (sheet 5). About $7.2 \mathrm{~km}$ (4.5 mi) above the mouth of Clam Creek, a headward-extending south tributary of Deep Creek cut off the headwaters of Clam Creek, diverting the captured drainage northward $2.4 \mathrm{~km}$ ( 1.5 mi) into Deep Creek, and leaving the lower, beheaded reach with greatly diminished discharge derived from precipitation and local seepages. The lower beheaded reach is filled with sand of a former braid delta related to the 65-m ( 215-ft) lake. We will parallel this former drainage for the next $3.2 \mathrm{~km}$ ( 2 mi) before crossing lower Clam Creek.

The straight upper middle reach of Clam Creek trends generally northwest parallel to the courses of the Ninilchik River and Deep Creek, in direct alignment with probable faults in the Caribou Hills. A complex of near-vertical faults with conjugate or near-conjugate components in the Caribou Hills is delineated by linear drainage segments and topographic depressions, straight and abrupt changes in vegetation, aligned swamps and bedrock knobs, lines of springs, upslope-facing scarps, and offset bedrock ridges (R.D. Reger, unpublished data). The ages of these faults have not been evaluated, but some appear to be quite fresh.

MP 140.9, Sterling Highway. Crossing of lower Clam Creek. To the right (west) this small drainage is cut into sandstones of the Sterling Formation.

MP 142.5, Sterling Highway. Begin descent into former channel of Happy Valley Creek. 


\section{STOP 10. PALEOCHANNEL OF ANCESTRAL HAPPY VALLEY CREEK}

A 142.6, Sterling Highway. Turn right (west) into parking area for Stop 10.

We are just beginning to realize that many of the more obvious so-called shorelines previously identified (Karlstrom, 1964, sheet 4) are actually scarps cut by streams wandering across former lake bottoms, and our knowledge of the ages and deposits of various paleochannels is very limited. This paleochannel is cut into bottom sediments of the 80-m ( 260-ft) and 65-m ( 215-ft) lakes and is probably post-late Moosehorn in age. The gravel fill in this paleochannel is $\sim 3-4 \mathrm{~m}$ ( 10-13 ft) thick, and equivalent elevations of $\sim 55 \mathrm{~m}$ ( $\sim 180 \mathrm{ft}$ ) indicate that this channel is related to the paleochannel traversed by the Sterling Highway through Happy Valley south of here (sheet 6).

To the west across Cook Inlet is Iliamna Volcano (3,053 m [10,016 ft] elevation), a picturesque snow- and ice-covered stratovolcano with a history of explosive eruptions $\sim 7.0$ RC kya ( 7.9 cal kya) and $\sim 4.0$ RC kya ( $\sim 4$ cal kya); possible explosive eruptions with pyroclastic flows and noncoherent lahars $>2.3$ RC kya $(\sim 2.3$ cal kya), 300 RC ya ( 300 cal ya), and $\sim 140$ RC ya ( 135 cal ya); and flank collapses associated with debris avalanches, cohesive lahars, and possible eruptions 2.3 RC kya ( 2.3 cal kya), and $\sim 90$ RC ya ( 100 cal ya) (Waythomas and Miller, 1999).

A study of soil charcoal by Berg and Anderson (2006) was designed to determine late Holocene fire history in the western Kenai Peninsula lowland. Relatively high wildfire frequencies occurred during the Little Ice Age between 1300 A.D. and the late 1800s A.D. and during a period of glacial advance in the southern Kenai Mountains called the Early Medieval Advance between 600 and 850 A.D. (fig. 74). We suggest that these periods of more frequent wildfire were possibly related to expansions of lowland black spruce forests, which burn much more frequently than white spruce. On the peninsula, the post-settlement mean return interval for fires in black spruce is $\sim 80$ yr (De Volder, 1999), whereas the mean recurrence interval for white/Lutz spruce during the past 2,500 yrs has been $\sim 400$ to 600 yrs with an average time since the last fire of $\sim 600 \mathrm{yrs}$ (Berg and Anderson, 2006) (fig. 75). Comparison of recurrence intervals between wildfires in the Kenai Peninsula lowland coniferous forests and major infestations by spruce bark beetles indicates no direct relation (fig. 75).

Spruce in the southern Kenai Peninsula lowland show evidence of widespread attack by the spruce bark beetle (Dendroctonous rufipennis) during a massive beetle infestation in the 1990s A.D. as a direct result of climatic warming. Historical evidence indicates that a series of two or more summers with temperatures $>10^{\circ} \mathrm{C}$ $\left(>51^{\circ} \mathrm{F}\right)$ generally produces a beetle outbreak. During the 11-year period from 1987 A.D. through 1997 A.D., warm summer temperatures caused spruce bark beetles to essentially 'eat themselves out of house and home' and to spread extensively throughout southcentral Alaska (Berg and others, 2006; Berg, 2006) (fig. 76). Tree-ring measurements documenting the timing of growth pulses ${ }^{21}$ in spruce have determined that beetle outbreaks occurred on the southern peninsula in the 1810 s to 1820 s A.D., 1870s to 1880s A.D., 1910s A.D., and 1970s A.D. (Berg

${ }^{21}$ Surviving spruce begin adding wider growth rings when surrounding beetle-killed trees die and access to sunlight becomes unimpeded.

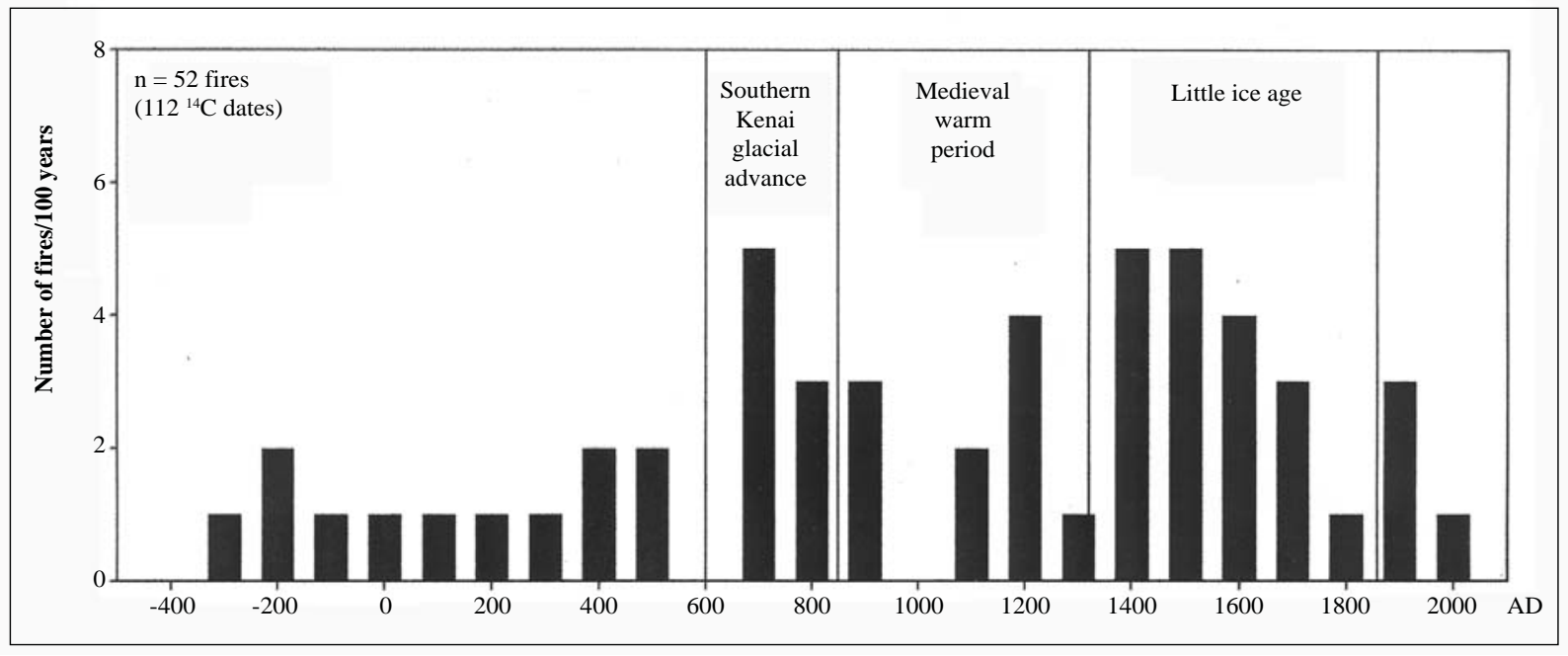

Figure 74. Histogram of fire frequency in southern Kenai Peninsula lowland determined from soil charcoal compared to glacial intervals in southern Kenai Mountains (Wiles and Calkin, 1994; Berg and Anderson, 2006). 
and others, 2006) (fig. 77). The 1880s A.D. outbreak was very severe on the Kenai Peninsula, but the 1990s A.D. outbreak, when $>429,000$ ha ( $>1$ million acres) of Kenai Peninsula forest were devastated, was unprecedented in scale and intensity during the past 250 yrs and could change the character of Kenai Peninsula forests in the future (Berg, 2007).

MP 143.9, Sterling Highway. Crossing of modern channel of Happy Valley Creek, which enters a narrow canyon $\sim 0.1 \mathrm{mi}(0.16 \mathrm{~km})$ downstream from the Sterling
Highway and plunges steeply 30 m ( 100 ft) through Sterling Formation to Cook Inlet.

MP 144.3, Sterling Highway. To the left (east) is a prominent scarp cut into the slope at $\sim 55 \mathrm{~m}(\sim 180$ $\mathrm{ft}$ ) elevation by ancestral Happy Valley Creek as it wandered across and eroded into the floor of the 65-m ( 215-ft) lake. For the next $2.4 \mathrm{~km}(\sim 1.5 \mathrm{mi})$ we will drive down the former paleochannel, which is underlain by 4-5 m (13-16 ft) of fluvial pebble gravel with numerous cobbles.

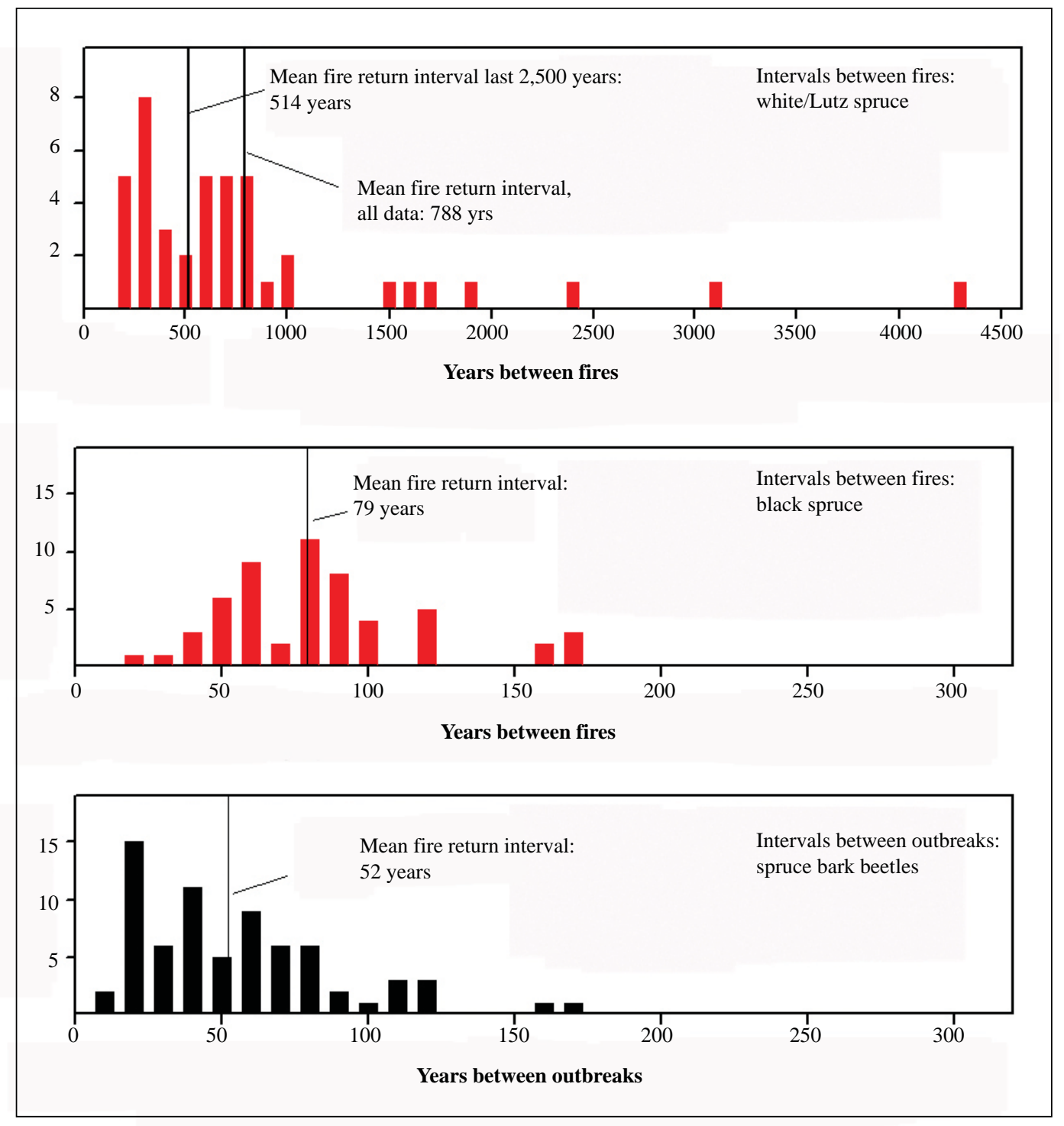

Figure 75. Histogram of mean fire return intervals (MFI) between wildfires in white/Lutz spruce and black spruce related to outbreaks of spruce bark beetles. MFI for white/Lutz spruce based on 41 intervals at 21 sites with 121 radiocarbon dates. MFI for black spruce based on 55 intervals at 165 sites with fire-scars and burn poles. Mean beetle outbreak return interval based on 71 intervals at 23 sites, including one site at Polly Creek on west side of Cook Inlet (De Volder, 1999; Berg and Anderson, 2006; Berg and others, 2006). 


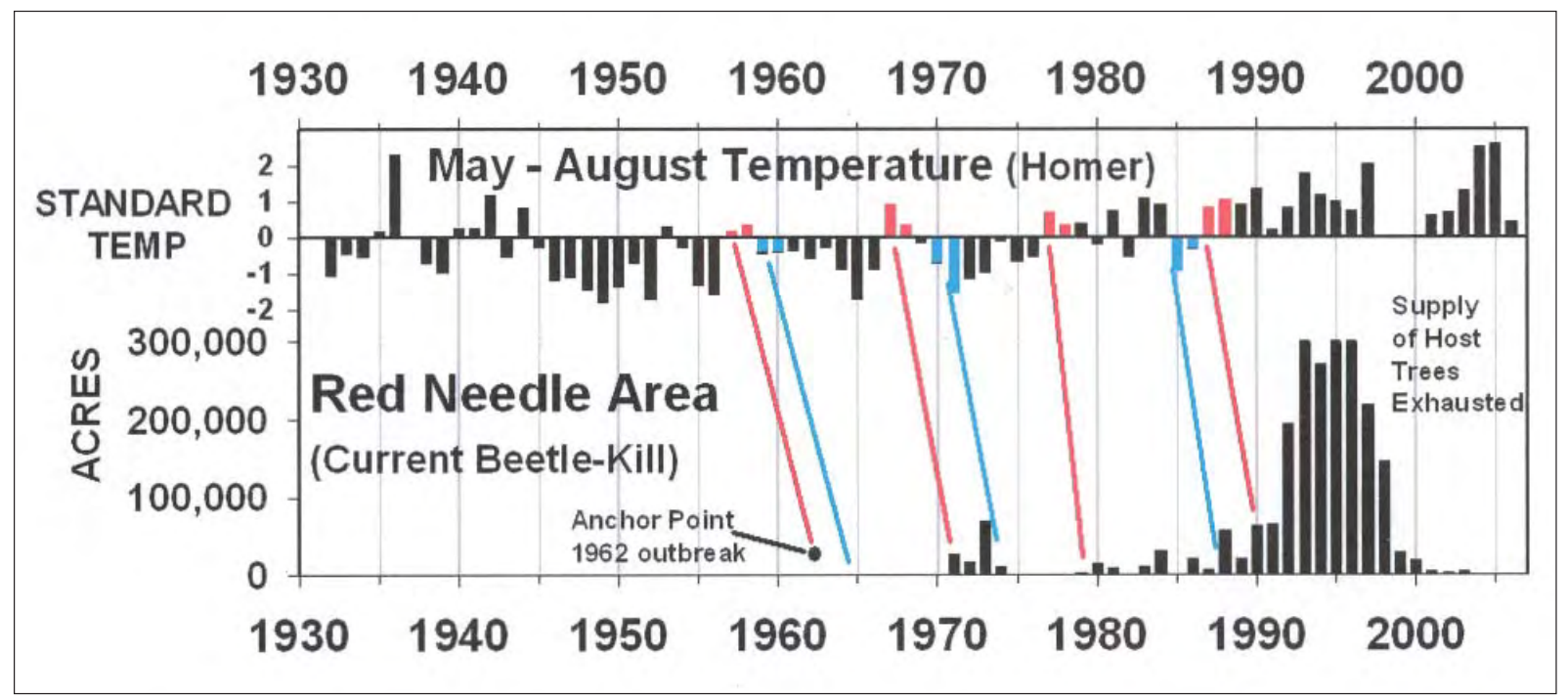

Figure 76. Standard deviations from mean summer temperatures from 1932 A.D. through 2005 A.D. at Homer, Alaska, related to frequency and intensity of bark beetle attacks in southern Kenai Peninsula lowland (Berg and others, 2006).

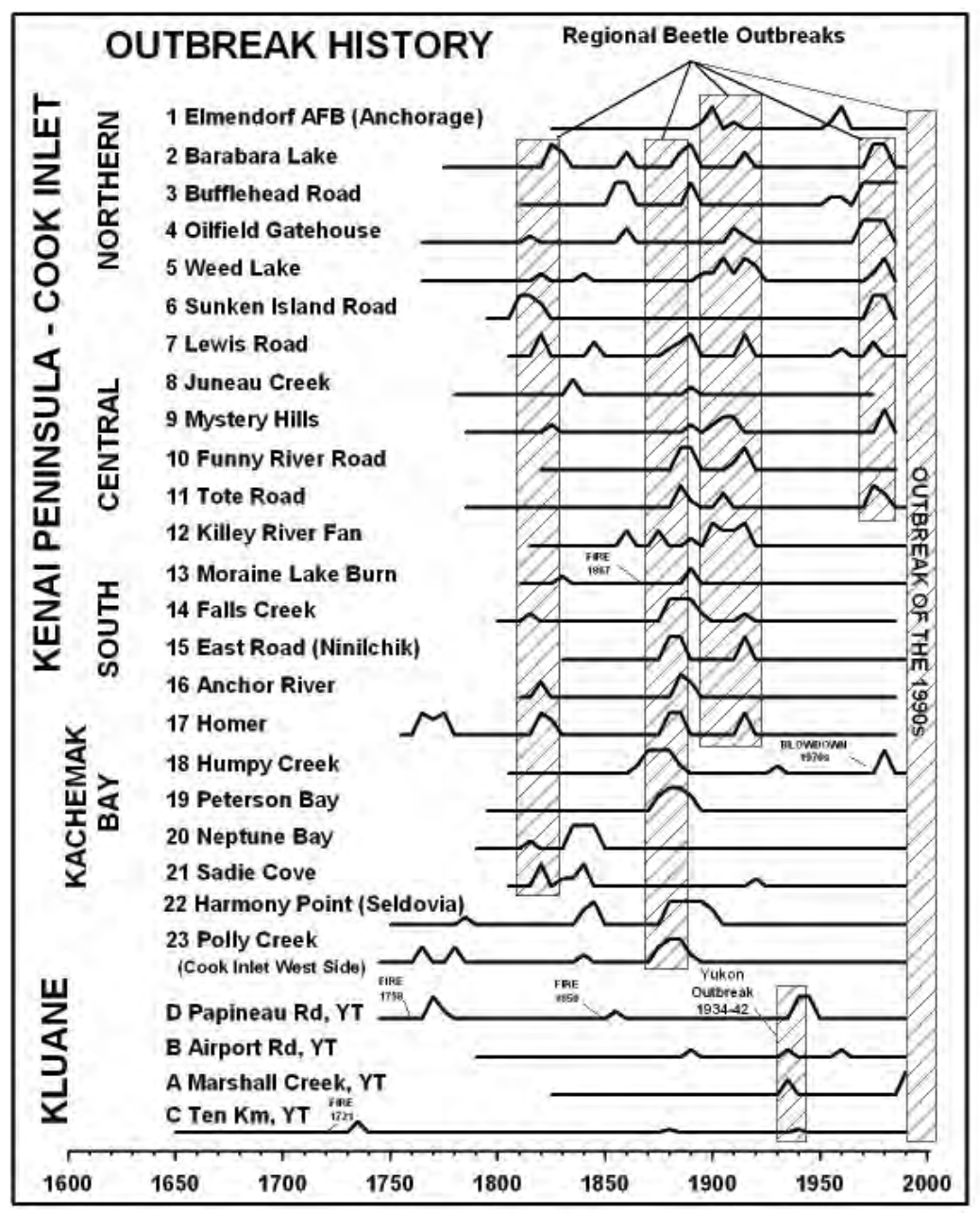

Figure 77. Summary of release pulses in white and Sitka/Lutz spruce in western Kenai Peninsula and upper Cook Inlet region (Berg and others, 2006). 
MP 146, Sterling Highway. Leave paleochannel and ascend scarp up across subtle 65-m ( 215-ft) shoreline onto floor of 80-m ( 260-ft) lake.

MP 147.7, Sterling Highway. Floor of 80-m ( 260-ft) lake.

MP 150.8, Sterling Highway. Crossing of Stariski Creek.

MP 151.1, Sterling Highway. To the right (northwest) is a broad terrace of lower Stariski Creek at $\sim 47 \mathrm{~m}(\sim 154 \mathrm{ft})$ elevation. Terrace alluvium, which is $\sim 4 \mathrm{~m}(\sim 13 \mathrm{ft})$ thick, has been extensively mined for aggregate.

MP 152.5, Sterling Highway. Whiskey Gulch, which provides public access down a short but very steep road to the beach.

MP 153.3, Sterling Highway. Headward erosion by the steep-walled gully to the west has cut into the floor of the 80 -m ( 260-ft) lake to within $\sim 17 \mathrm{~m}$ ( $56 \mathrm{ft})$ of the Sterling Highway and will eventually force relocation of the highway.

MP 156.l, Sterling Highway. Entering the settlement of Anchor Point.

\section{STOP 11. MOUTH OF ANCHOR RIVER}

AP 157.1, Sterling Highway. Turn right on old Sterling Highway and proceed $0.5 \mathrm{~km}(\sim 0.3 \mathrm{mi})$ south- west to the steel-girder Anchor River bridge. As you cross the river, note the large erratics in the floodplain of the Anchor River to the right. Just past the bridge, turn right (west) and drive $2.9 \mathrm{~km}(\sim 1.8 \mathrm{mi})$ across the inactive floodplain of the Anchor River to the parking lot at the end of the beach access road for Stop 11. Note the rise from the inactive floodplain up onto the outwash terrace of Killey age $1.1 \mathrm{~km}(\sim 0.7 \mathrm{mi})$ after turning onto the beach access road.

We are standing at the westernmost point of the Kenai Peninsula lowland and the contiguous road network at $\sim 5 \mathrm{~m}$ ( $\sim 16 \mathrm{ft}$ ) elevation. The mouth of the Anchor River, which drains $582 \mathrm{~km}^{2}\left(\sim 224 \mathrm{mi}^{2}\right)$ of the southern Caribou Hills (Curran and others, 2003), is $\sim 40 \mathrm{~m}(\sim 130 \mathrm{ft}$ ) below the floor of the impounded glacial lake of Moosehorn age. The lower $12.8 \mathrm{~km}$ ( 8 mi) of Anchor River follows the northeastern margin of a terminal moraine of the Kachemak Bay lobe that was emplaced during the Moosehorn stade (sheet 6). Coastal-bluff stratigraphy indicates that this large ice lobe floated, at least partially, in the impounded lake that occupied the southern Kenai Peninsula lowland during the Moosehorn stade and built a sandy delta into the lake (fig. 78). At least $25 \mathrm{~m}$ ( 80 $\mathrm{ft}$ ) of lacustrine deposits exposed in high coastal and river bluffs in this deep part of the former lake basin typically are blue-gray clayey silts with traces of fine sand that coarsen upsection into fine sand; some of the scattered subangular to subrounded granule and pebble dropstones are composed of clastic coal (Reger and Petrik, 1993, fig. 3). No shells have been found in these deposits. Logs of water wells indicate that Moosehorn

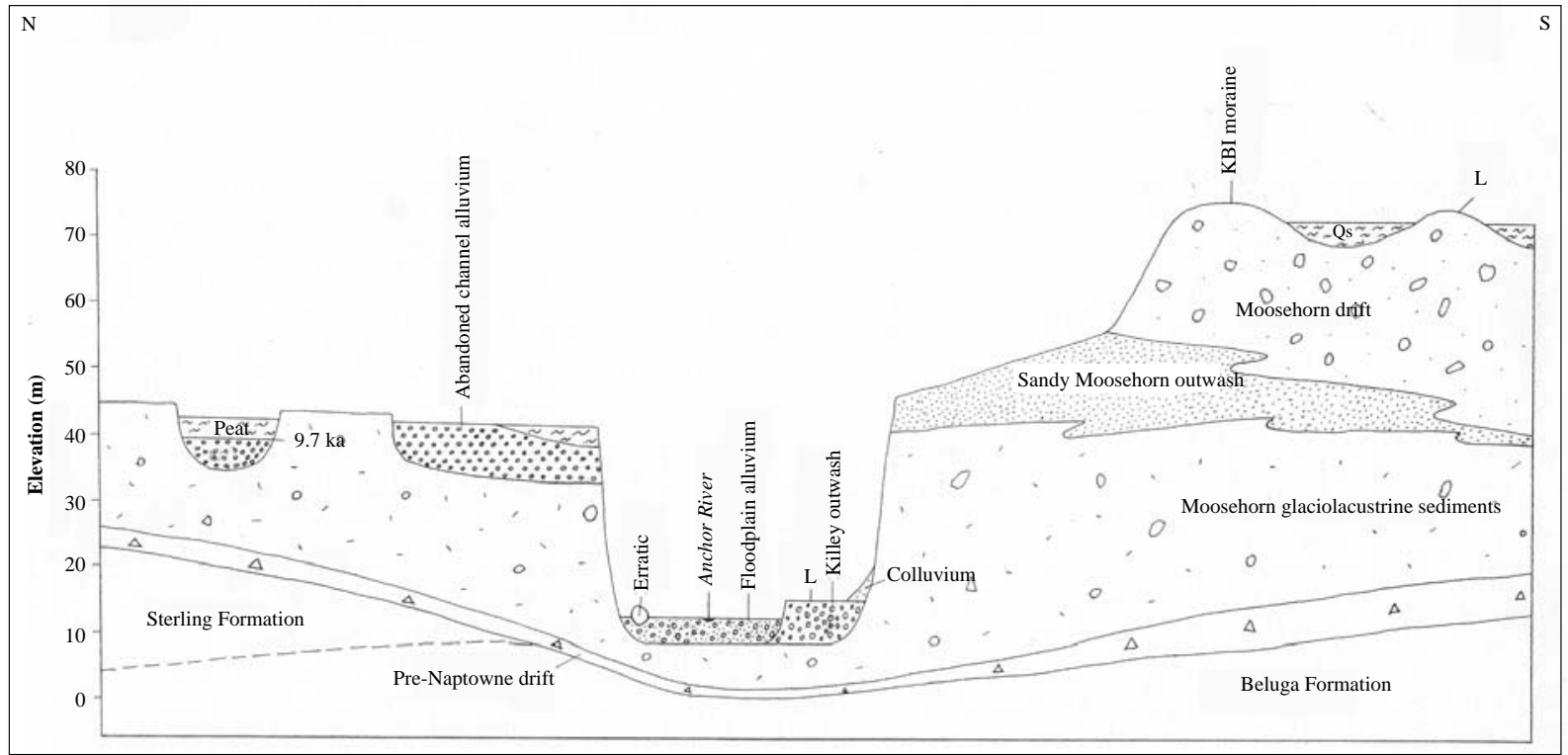

Figure 78. Physiography and stratigraphy of lower Anchor River valley. Radiocarbon ages in calibrated yr x $10^{3}$ (ka). Symbols: $\mathbf{L}=$ Lethe tephra; $\mathbf{K B 1}=$ Kachemak Bay I moraine (Moosehorn stade); $\mathbf{Q s}=$ swamp deposits. 
lake sediments are $\sim 30-34 \mathrm{~m}$ ( 98-111 ft) thick over Tertiary bedrock 6.4 km ( 4 mi) up Anchor River (R.D. Reger, unpublished data).

Drainage from the southern Caribou Hills joined meltwater from the north flank of the Kachemak Bay lobe in the upper Anchor River during the Moosehorn and Killey stades (sheet 6). Physiographic and stratigraphic evidence indicates that the lower Anchor River incised deeply into the lacustrine basin fill after the drainage of the 65-m (215-ft) lake and before the deposition of Killey outwash in the terrace in the valley bottom. Lethe tephra is present above outwash gravels on the outwash terrace at $\sim 16 \mathrm{~m}(\sim 53 \mathrm{ft})$ elevation near our location (Reger and others, 1996, fig. A75). The presence of coarse outwash this close to the modern coast indicates that rising eustatic sea level had not caught up with isostatic rebound during the Killey stade in the southern Kenai Peninsula lowland. A water well penetrated $3.6 \mathrm{~m}$ (12 ft) of granular river alluvium overlying $10.3 \mathrm{~m}$ (34 ft) of fine-grained glaciolacustrine sediments beneath the floodplain of the Anchor River $1.3 \mathrm{~km}(\sim 0.8 \mathrm{mi})$ southeast of our location (Coble and W.J. Nelson and Associates, 1998). Large erratics in the floodplain of the lower Anchor River are dropstones of Moosehorn age that have been eroded out of glaciolacustrine deposits in the bluffs above.

The coast here at Anchor Point displays features typical of the southern coast of the Kenai Peninsula lowland, where most of the coastal cliffs and bluffs expose Tertiary sedimentary rocks and bedrock slopes shallowly toward the inlet (fig. 79). Glacial erratics are much less common than in the Nikiski-Captain Cook State Park area. Beach deposits are thin and underlain by a cobble-boulder lag made up of erratics derived from multiple sources. To the south, large concretions weather out of the Beluga Formation and litter local beaches. Gold-bearing beach placers were discovered in the Anchor River area in March 1889 by Robert Michaelson (Barry, 1997). The gold was very fine grained but, in spite of small volumes, sustained local miners into the early 1900s A.D. (Hoekzema, 1985). Possible sources of the fine placer gold are reworked Quaternary deposits and paleoplacers in Tertiary sedimentary rocks. Cieutat and others (1992) reported anomalous gold in heavy-mineral concentrates that could have been derived from both sources. However, they located one outcrop of Tertiary or Quaternary conglomerate up Fox River

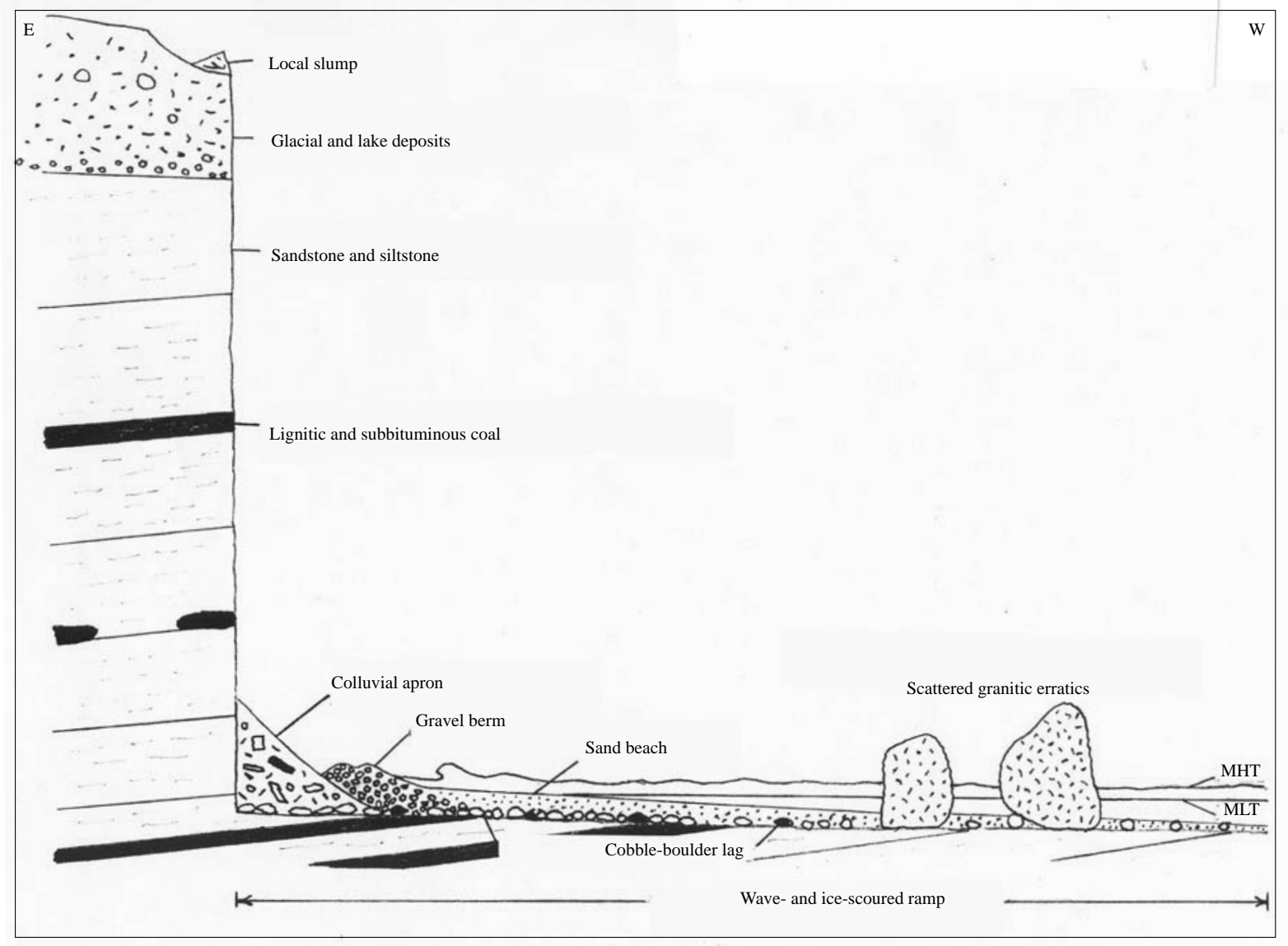

Figure 79. Typical section in coastal bluffs of southern Kenai Peninsula lowland. Symbols: MHT = mean high tide; $M L T=$ mean low tide. 
at the head of Kachemak Bay, where sluice and rock samples yielded anomalous gold values, indicating that the ultimate source of the gold is the Kenai Mountains to the east.

From a 2.7-m- (8.9-ft-) thick kettle filling with a maximum age of $\sim 9.3 \mathrm{cal}$ ka in the coastal bluff $1.9 \mathrm{~km}$ ( 1.2 mi) south of the mouth of Anchor River, Lemke (2000) collected several distal tephras in 1997 A.D. and determined their major-oxide contents with an electronmicroprobe. Using similarity coefficients developed by Borchardt and others (1972) and similarities of silica contents, she assigned as probable six tephras (Ha, Ia, M, O-Q) dating from $\sim 1,170$ to $\sim 6,940$ cal yr B.P. to Augustine Volcano as the source volcano. She assigned with degrees of certainty ranging from strong to probable to most likely three tephras (J, L, Sa) dating from 3,040 to $\sim 7,760 \mathrm{cal}$ yr B.P. to Iliamna Volcano. Of much less significance, she attributed a single tephra $(\mathrm{N})$ dating $\sim 5,150$ cal yr B.P. to Katmai Volcano and one tephra (K) dating 3,605 cal yr B.P. to Hayes Volcano in upper Cook Inlet. On the basis of her study, Lemke (2000) believed that the recurrence interval for tephrafalls at Anchor Point averages 520 cal yr.

Return to Sterling Highway through the town of Anchor Point and turn right toward Homer.

MP 157.2, Sterling Highway. Crossing of the North Fork Anchor River.

MP 157.3, Sterling Highway. For the next 0.6 $\mathrm{km}(\sim 0.4 \mathrm{mi})$, the Sterling Highway passes several large gravel pits at $\sim 47 \mathrm{~m}(\sim 155 \mathrm{ft})$ elevation. Their elevations below $65 \mathrm{~m}(215 \mathrm{ft})$ indicate that they postdate drainage of the 65-m (215-ft) impounded lake, which is corroborated by the presence of Lethelike tephra in excavations between $\sim 50$ and $60 \mathrm{~m}$ ( 165 and $195 \mathrm{ft}$ ) elevation (R.D. Reger, unpublished data). The paleochannels were cut by the meandering ancestral North Fork Anchor River, which was graded to the ancestral Anchor River as it cut downward through the soft underlying lake deposits after drainage of the 65-m (215-ft) lake in late Moosehorn time and before the deposition of Killey outwash. A distant-minimum age is provided by wood, dated at $8,745 \pm 100$ RC yr B.P. (GX-18,404) (9,778 $\pm 100 \mathrm{cal}$ yr B.P.), beneath a 2.6-m- (8.5-ft-) thick surface peat overlying fluvial gravel at $\sim 50 \mathrm{~m}(\sim 165 \mathrm{ft})$ elevation in a paleochannel northeast of Anchor Point (Reger and others, 1996, fig. A72).

MP 158.1 to MP 158.3, Sterling Highway. We cross another paleochannel of the North Fork Anchor River at $\sim 47 \mathrm{~m}(\sim 155 \mathrm{ft})$ elevation.

MP 158.5, Sterling Highway. Crossing an older, peat-blanketed paleochannel of the North Fork Anchor River at $\sim 60 \mathrm{~m}(\sim 200 \mathrm{ft})$ elevation. Coring penetrated
$1.8 \mathrm{~m}$ (5.9 ft) of peat blanketing this feature (R.D. Reger, unpublished data). Winter winds keep snow blown off this peatland, and the morphologies of small spruce trees are altered (flagged) in the zone of saltating, windblown snow grains.

MP 159.4, Sterling Highway. Several large gravel pits at $\sim 60 \mathrm{~m}(\sim 200 \mathrm{ft})$ elevation occupy post-Moosehorn paleochannels of the North Fork Anchor River. A 30-cm(11.8-in-) thick layer of retransported Lethelike tephra was found in one of these pits (R.D. Reger, unpublished data). Anchor Point gravel pits are the chief source of aggragate in this area (Reger and Carver, 1977; Reger and Petrik, 1993).

Now we descend onto the inactive floodplain of the Anchor River, which we will cross for 2.4 km ( 1.5 mi). The Anchor River floodplain was seriously impacted by the unusually large flood in 2002 A.D. Bridges were destroyed, and large cottonwood trees were piled outside stream bends along the highway.

MP 161, Sterling Highway. Crossing of the Anchor River bridge. Glaciolacustrine deposits of Moosehorn age are exposed in the high river bluff to the left (northeast).

MP 161.5, Sterling Highway. Drive up onto the edge of the Moosehorn terminal moraine of the Kachemak Bay lobe, which we will traverse for the next $1 \mathrm{~km}$ (0.6 mi).

MP 162.7, Sterling Highway. We will cross post-Killey terraces of the Anchor River for $1.1 \mathrm{~km}$ ( $\sim 0.7 \mathrm{mi}$ ). To the right (west), the discontinuous scarp of the Killey-age outwash terrace of ancestral Anchor River stands above the highway.

MP 164.3, Sterling Highway. To the left (east) is the sharp diversion elbow of the Anchor River, where the river encountered the east flank of the Kachemak Bay lobe during the Moosehorn advance (sheet 6). Drive up onto the Moosehorn moraine.

MP 164.6, Sterling Highway. Junction of the old Sterling Highway and the Sterling Highway. To our left (east) is a network of former ice-marginal channels of ancestral Diamond Creek that drained the northern flank of the Kachemak Bay lobe during the Moosehorn stade (sheet 6). For the next $4 \mathrm{~km}$ (2.5 mi) we will parallel these dry channels along this beheaded reach of ancestral Diamond Creek. In post-Moosehorn time a steep tributary to western Kachemak Bay cut headward, probably along a normal fault in the Beluga Formation (Karl and others, 1997b, p. 111), and eventually intersected ancestral Diamond Creek, diverting the upper drainage $2.1 \mathrm{~km}(\sim 1.3$ mi) down Diamond Gulch into Kachemak Bay. 
Behind (east of) the paleochannel, the uplands were glaciated during the penultimate glaciation of the southern Caribou Hills, and, in general, formless drift thinly covers the Tertiary bedrock. However, on lower slopes northeast of Kachemak Bay, ridge morphology of late penultimate lateral moraines is preserved. Above these features, the relief of older drift is generally subdued, although knobs of till are recognizable. Exposures of this drift reveal no significant weathering of clasts, although scattered cobbles are lightly stained with iron oxides and scratches attributed to glacial abrasion remain clearly visible.

MP 167.6, Sterling Highway. Crossing of Diamond Creek and Diamond Gulch.

\section{STOP 12. BLUFF POINT OVERLOOK}

MP 169, Sterling Highway. Driving around the headwall of the large Bluff Point failure. At MP 169.6, turn right for Stop 12.

Kachemak Bay is a deep, photogenic fjord that is $40 \mathrm{~km}$ (25 mi) long and measures $38 \mathrm{~km}$ (24 mi) across the mouth. This large bay separates the southern Kenai Peninsula lowland, which is underlain by a thick section of Tertiary sedimentary rocks (Barnes and Cobb, 1959), from the southern Kenai Mountains with their complex geology to the southeast (Bradley and others, 1999). Today, the scenic Kenai Mountains support icefields and alpine glaciers that can be seen from this location. We will discuss the Holocene history of these glaciers in Homer at Stop 13. On a day with good visibility the symmetrical cone of Augustine Volcano can be seen $107 \mathrm{~km}$ ( 67 mi) west-southwest from our location. Of several Cook Inlet volcanoes, Augustine Volcano has been the most active during the historic period, erupting explosively in 1812 A.D., 1883 A.D., 1935 A.D., 1963-64 A.D., 1976 A.D., 1986 A.D., and 2006 A.D. This small stratovolcano has a long history of violent eruptions that produced numerous prehistoric tephras and debris avalanches resulting from the collapse of unstable summit domes (Riehle, 1985; Kienle, 1990; Begét and Kienle, 1992; Begét and others, 1994; Reger and others, 1996; Waythomas and Waitt, 1998; Lemke, 2000). Lemke (2000) collected several tephras from the coastal bluff $0.6 \mathrm{~km}(\sim 0.4 \mathrm{mi})$ east of Homer Spit in Kachemak Bay and correlated nine ash layers with layers dated $>900$ cal ya and <8,825 cal ya at her Anchor Point site. On the basis of similarity coefficients and silica contents, she identified Augustine Volcano as the probable source of five tephras (Ba, E, F, Ga, L) ranging in age from 900 cal ya to $\sim 7,760$ cal ya and related four tephras (Ja, K, $\mathrm{P}, \mathrm{Q})$ ranging in age from $>6,405$ to $<12,000$ cal ya to Iliamna Volcano. The setting in the southwestern corner of Cook Inlet and the history of frequent violent eruptions make Augustine Volcano one of the most threatening volcanoes in the inlet because eruption-triggered tsunamis are possible, like the series of sea waves up to $6 \mathrm{~m}$ ( 20 ft) high that struck Nanwalek during an Augustine eruption on October 6, 1883. However, evidence of this event remains elusive, and the likelihood of volcanogenerated tsunamis is controversial (Waythomas, 2000; Waythomas and Waitt, 1998).

Homer Spit, which is $11 \mathrm{~km}(\sim 7 \mathrm{mi})$ east of our location, is one of the best-known landmarks in lower Kachemak Bay. The presence of erratic boulders in lower beach deposits and the concave form facing the mouth of Kachemak Bay (similar to end moraines in Norwegian fjords) encouraged Karlstrom (1964, p. 20) to first suggest that Homer Spit formed initially as a submarine terminal-moraine complex during the Skilak stade as a result of the grounding of the tidewater Kachemak Bay lobe on Tertiary bedrock in the northwestern half of the bay (fig. 80). Archimandritof Shoals, which is just seaward of Homer Spit, was associated with the moraine as a gravelly submarine fan where a subglacial river emerged from beneath the glacier. Today, following a period of isostatic rebound that lifted the moraine core into shallower waters, shoreline processes, like longshore drift that are typical of spits elsewhere, operate along Homer Spit. Depth to bedrock at the outer end of the spit is $\sim 86 \mathrm{~m}$ ( 280 ft) (Waller, 1966, table 2).

We are standing $215 \mathrm{~m}$ (705 ft) above the waters of Kachemak Bay at the crown of a massive rock failure, by far the largest landslide along the west coast of the Kenai Peninsula lowland. The body of this massive feature measures $5.4 \mathrm{~km}$ (3.4 mi) long, up to $2.6 \mathrm{~km}$ (1.6 mi) wide, and is composed of disrupted blocks of the sandstone-rich bedrock (Beluga Formation) (Reger, 1979). Surface relief is $\sim 60 \mathrm{~m}(\sim 200 \mathrm{ft})$, and shallow ponds occupy poorly drained depressions. Topographic lows contain mixed alluvial and colluvial fills, and colluvial cones rest against the steep bedrock headwall, which is locally notched as deeply as $\sim 160 \mathrm{~m}(\sim 525 \mathrm{ft})$. The body of the landslide has been extensively modified by postfailure coastal processes. Submarine contours and concentrations of subtidal blocks demonstrate that up to $0.6 \mathrm{mi}$ (1 km) of notching has occurred in response to wave attack, exposing up to $30 \mathrm{~m}$ (100 ft) of slide and postslide debris (fig. 81). Wood collected from the colluvial fill provided distant-minimum ages of $\sim 1.1$ and $\sim 1.6$ RC ka ( 1.5 and 1.1 cal ka) (Reger, 1979). A position well inside the Moosehorn limit of the Kachemak Bay lobe and lack of evidence of modification by Killey ice (sheet 6) set a maximum age for the failure event(s), and the degree of surface modification of the headwall and slide body indicate that the landslide is quite old. Assuming that the failure occurred in response to loss of lateral support when the buttressing glacier retreated 
along the glacially over-steepened bluff face, perhaps triggered by a large earthquake, the failure could have occurred any time after post-Killey retreat of the Kachemak Bay lobe. An unknown factor is whether the landslide occurred as one massive collapse or a series of smaller

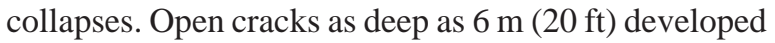
along the crown of the landslide during the 1964 A.D. earthquake (Waller, 1966), indicating that future failures of the headwall are inevitable. Piling the spoil from widening the roadcut behind us along the headwall certainly reduced the stability of the headwall in this area.

MP 170.7, Sterling Highway. During the long descent into Homer, the Sterling Highway crosses extensive colluvial fans composed principally of debris flows emanating from steep canyons and gullies in the Tertiary bedrock above the highway (Reger and Carver, 1977). Note that many houses are being constructed on upper fan surfaces and even in the mouths of the steep, bedrock-walled canyons and gullies. Fan deposits have a fine-grained matrix derived from weathering and erosion of the sandstone-dominated bedrock exposed in the canyons and gullies upslope. Scattered through this matrix are blocks of coal, cobble and boulder erratics, and plant debris up to the size of trees. Excavations in debris-flow deposits indicate that they are locally thicker than $\sim 40 \mathrm{ft}(12 \mathrm{~m})$. The fan emanating from each gully consists of several debris flows, and many of these debris flows extend beyond the fan limits down ephemeral stream channels.

These debris flows are a supply-limited phenomenon. Each event essentially empties the source area of accumulated debris. Their recurrence requires (1) a significant recharge interval after the previous flow event to accumulate sufficient debris in the source canyon or gully, and (2) a hydroclimatic event of sufficient duration and magnitude to soak the accumulated debris (Jakob, 2005). Large canyons, with their complex of steep tributaries, produce the largest debris flows. Smaller, simpler gullies produce smaller flows. Return intervals are estimated to be decades to centuries, and small events occur more frequently than large events. Events are generally initiated by a small debris slide from a steep wall. This slide imparts an initiating pulse

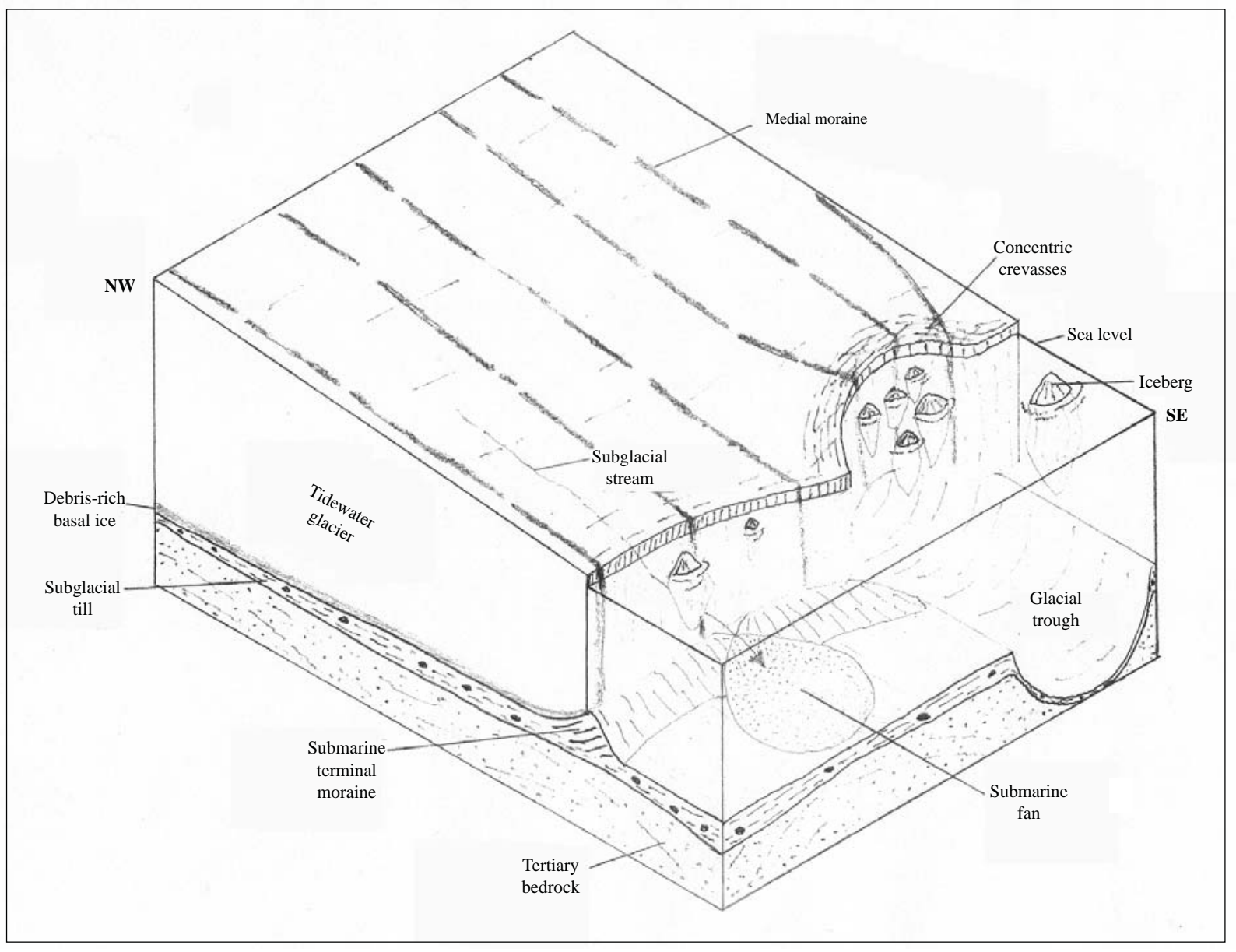

Figure 80. Formation of Homer Spit as a submarine terminal moraine. 
through the body of the saturated, unstable debris in the inclined channel below, which then starts flowing down the canyon or gully floor.

\section{STOP 13. KAREN A. HORNADAY HILLSIDE PARK}

MP 172.6, Sterling Highway. Junction of Sterling Highway and Pioneer Avenue. Turn left (northeast) and drive $0.16 \mathrm{~km}(\sim 0.1 \mathrm{mi})$ on Pioneer Avenue to Bartlett Street. Turn left onto Bartlett Street and drive $0.6 \mathrm{~km}$ ( $\sim .4 \mathrm{mi}$ ) north uphill past the Pratt Museum to Fairview Avenue. Turn left (west) on Fairview Avenue and proceed $0.16 \mathrm{~km}(\sim 0.1 \mathrm{mi})$ to Campground Road at the large sign for Karen A. Hornaday Hillside Park. Turn right (north) and drive uphill on Campground Road $\sim 0.16 \mathrm{~km}(\sim 0.1 \mathrm{mi})$ to the park for Stop 13 .

We are standing at the top of the Homer bench, the gently sloping lowland below us that is underlain by a complex of debris-flow deposits and drift of the last major glaciation, near the mouth of Woodard Canyon, a steep canyon cut into weakly to moderately cemented Tertiary sedimentary rocks of the Homer escarpment above us. The steepness of the Homer escarpment is a result of scour by the Kachemak Bay lobe during the Moosehorn and Killey stades of the Naptowne glaciation. The Moosehorn lateral moraine follows the top of the escarpment (sheet 6). The upper limit of Killey ice is less obvious, but the Kachemak Bay lobe inundated the Homer bench up to a level $\sim 30 \mathrm{~m}(\sim 100 \mathrm{ft})$ up the escarpment above us. During the Skilak stade, the Kachemak Bay lobe was apparently a tidewater glacier that shaped the lower bench in the vicinity of the Beluga Lake lowland and, of course, Homer Spit (sheet 6).

As you saw en route to this location, most of the Homer bench has been developed, and perhaps you noticed that development to the northeast is extending upslope clear to the top of the escarpment, maybe because affordable, available land is becoming scarce and possibly to take advantage of the world-class view of Kachemak Bay and the southern Kenai Mountains. A serious concern is development on debris fans on the upper bench in the vicinity of the canyon mouths because of the likelihood of future debris-flow events. In addition to debris flows, the geology of the Homer area imposes other formidable constraints on development. First, there is the lack of suitable construction aggregate here. Aggregate has to be trucked $27 \mathrm{~km}(\sim 17 \mathrm{mi})$ from the Anchor Point area at considerable expense. Second, there are serious problems obtaining suitable quantities of potable water because of low well yields from the bedrock and overlying Quaternary deposits and objectionable amounts of iron, significant bicarbonate, and some methane produced by bacterial attack on coals in the Tertiary bedrock (Waller and others, 1968). To offset these disadvantages, surface water is collected and stored for distribution and fire protection by the City of Homer in a reservoir at the top of the escarpment. Third, lands close to the coast are impacted by mass movements and bluff recession caused ultimately

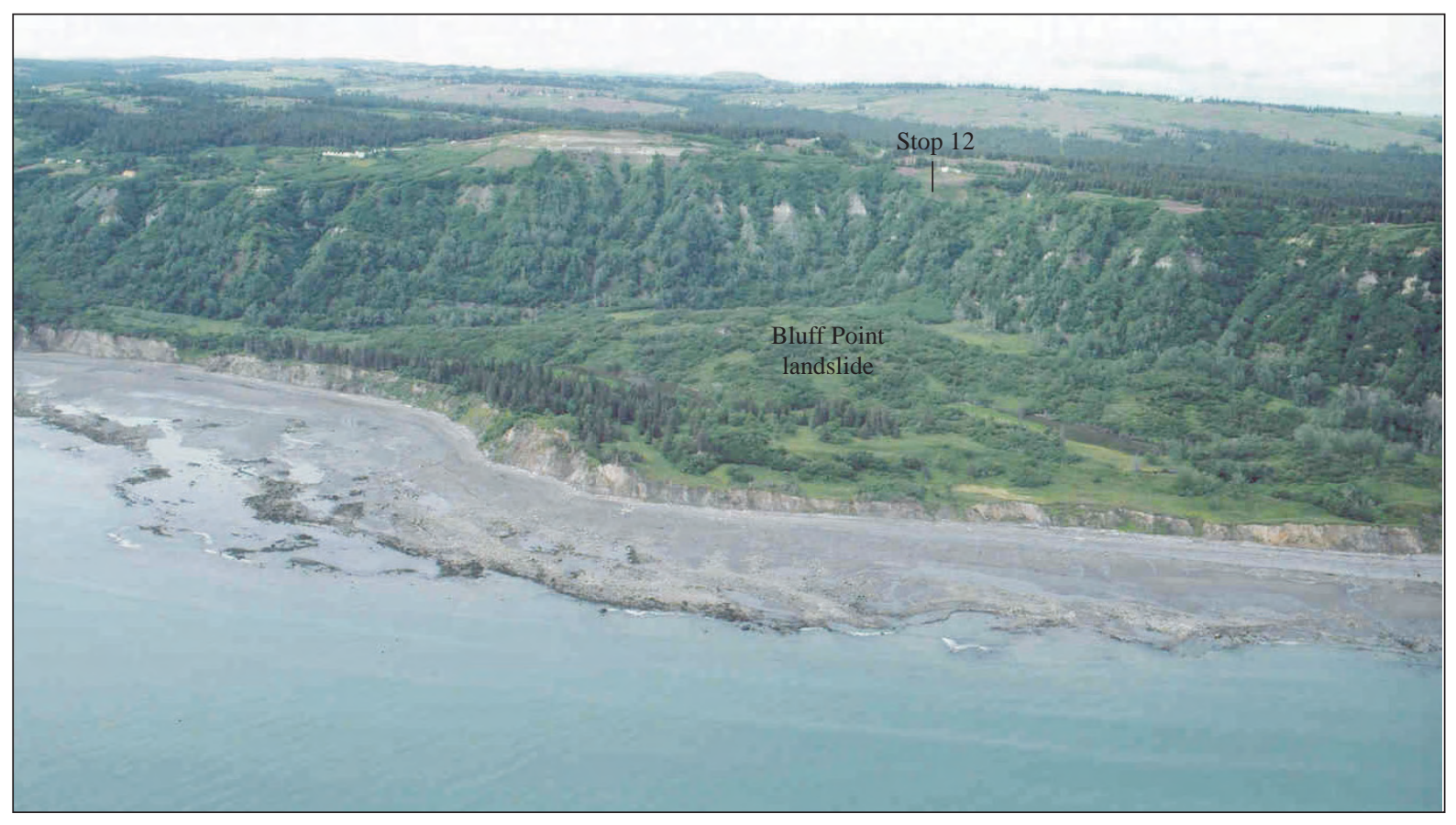

Figure 81. Aerial view looking north of Bluff Point landslide (photograph taken in May 1977). 
by shoreline erosion. Average shoreline erosion rates in the Homer area, determined from aerial photography, range from $0.46 \mathrm{~m} / \mathrm{yr}(1.5 \mathrm{ft} / \mathrm{yr})(1975-1996$ A.D.) to $1.49 \mathrm{~m} / \mathrm{yr}(4.9 \mathrm{ft} / \mathrm{yr})(1968-1975$ A.D.) (Steve Baird, unpublished data). Between 1951 and 2003 A.D., slightly higher erosion rates $(\sim 0.8 \mathrm{~m} / \mathrm{yr}[\sim 2.6 \mathrm{ft} / \mathrm{yr}])$ were measured west of Homer Spit than east of the spit, where the shoreline receded at a rate of $\sim 0.6 \mathrm{~m} / \mathrm{yr}(\sim 2 \mathrm{ft} / \mathrm{yr})$. Very few coastal bluff segments have little or no erosion (Mason and others, 1997).

Although scary, the great Alaska earthquake of March 27, 1964, produced relatively minor effects in the Homer area compared to other coastal communities. On the Homer bench, severe shaking affected utilities and numerous structures and destroyed considerable personal property. Ground cracking and slope failures were minor, a few wells went dry temporarily and water in other wells became temporarily turbid. To our knowledge, nobody died. The most significant changes affected Homer Spit, which settled 1.3 to $1.6 \mathrm{~m}$ (4.3 to $5.9 \mathrm{ft}$ ) in response to $\sim 0.6 \mathrm{~m}(2 \mathrm{ft})$ of tectonic subsidence and up to $\sim 1.2 \mathrm{~m}$ ( $4 \mathrm{ft}$ ) of sediment compaction (Stanley, 1966; Suleimani and others, 2005), resulting in flooded facilities and accelerated beach erosion, and a submarine slide removed most of the breakwater for the small boat harbor (Waller, 1966). In other coastal communities, tsunamis caused serious damage, and the Homer Spit may have been affected by tsunamis and seiching. Up to 14 unusual waves, some estimated to be $2.7 \mathrm{~m} \mathrm{(9} \mathrm{ft)}$ high, were reported encroaching on the shore (Waller, 1966), but their origins are unknown. Using the 1964 A.D. M9.2 Alaska earthquake to calibrate their model of submarine displacements to generate tsunamis, Suleimani and others (2005) produced 1:12,500-scale map of flooding scenarios for the coast at Homer caused by tsunamis generated by another 1964-style earthquake and by a hypothetical M7.5 earthquake on the Border Ranges fault, which trends across the base of Homer Spit in the subsurface (Bradley and others, 1999), and showed anticipated maximum inundations caused by all scenarios.

Ager (2000) produced the first dated records of latest Naptowne and Holocene vegetation in the southern Kenai Peninsula lowland at two sites in the Homer area. His 1.25-m (4.1-ft) peat section at $\sim 5 \mathrm{~m}(\sim 16 \mathrm{ft})$ elevation in the coastal bluff near the base of Homer Spit has a maximum age of $\sim 11.8 \mathrm{RC} \mathrm{ka}(\sim 13.7 \mathrm{cal} \mathrm{ka})(\mathrm{W}-5,521)$ and overlies $\sim 15 \mathrm{~cm}$ ( $\sim 6$ in) of sandy pond silts with scattered plant detritus above a probable marine bouldery till of late Killey age. The basal age of the section indicates that there was considerable delay between deposition of the Killey-age marine till and the first accumulation of freshwater deposits at this site, probably because isostatic rebound took several millennia to bring the site above the marine realm. The initial pollen assemblage is indicative of a birch-herb shrub tundra surrounding an open pond with pollen and plant debris dominated by shrub birch, willows, sedges, grasses, and aquatic plants accumulating in the pond and little sphagnum moss present (fig. 82). These circumstances persisted through the lower half of the peat section. About 10.2 RC ka (12.0 cal ka), sedges and ferns began invading the pond margins, perhaps indicating a shift toward wetter climate. An increase of sphagnum spores associated with an abrupt increase in pollen of shrub birch, alder, and ericaceous plants $\sim 9.5 \mathrm{RC}$ ka $(\sim 10.7 \mathrm{cal} \mathrm{ka})$ indicates that a shrubland with moss ground cover developed at the site during a fairly wet climate interval. This association persisted at least until $\sim 4.2$ to $\sim 3.8 \mathrm{RC}$ ka ( 4.6 to $\sim 4.2 \mathrm{cal} \mathrm{ka})$, when an increase in spruce pollen indicates that spruce (probably boreal in origin) approached the upland north of Kachemak Bay (fig. 82). However, spruce did not colonize the Homer bench until $\sim 2.6 \mathrm{RC}$ ka $(\sim 2.7 \mathrm{cal} \mathrm{ka})$. Evidence on the south side of Kachemak Bay indicates that Sitka spruce was present there at least as early as $\sim 1.7 \mathrm{RC} \mathrm{ka}(1.6 \mathrm{cal} \mathrm{ka})$ (Wiles and Calkin, 1994).

A similar chronology was obtained from a $4.5-\mathrm{m}$ (14.8-ft) core retrieved from Circle Lake, $27 \mathrm{~km}(\sim 17$ mi) east-northeast of the Homer Spit site at $\sim 410 \mathrm{~m}$ $(1,345 \mathrm{ft}$ ) higher elevation (Ager, 2000). The site is just inside the lateral moraine of Killey age (Reger, unpublished data). The Circle Lake core is slightly older than the Homer Spit peat section, having a basal age of $\sim 12.8 \mathrm{RC}$ ka (15.0 cal ka) (W-5,518). The basal zone in the core contains considerable pollen of grasses, sedges, Artemisia, Equisetum, and other herbaceous and aquatic taxa as well as the highest percentage of club moss spores in the entire core. This assemblage represents an herbaceous tundra with a discontinuous ground cover of club mosses that initially developed around this kettle lake on the deglaciated landscape (fig. 82). Woody plants (primarily shrub birch) represent a small percentage of this initial assemblage, which probably spread to the site from the nearby Caribou Hills refugium (Ager, 2000). In the vicinity of the kettle lake 12.5 RC kya (14.1 cal kya), willows increased at the expense of shrub birch, alders suddenly increased in importance, poplars made an initial appearance, and club moss declined in importance, while ferns increased with the development of shrub birch-herb tundra. A spike in Nuphar pollen about this time may indicate that water lilies initially colonized nearshore shallows or the lake became shallow. Roughly 9.6 RC kya (10.9 cal kya), alder, which was present in the vicinity quite early, became prominent at the expense of birch, grasses increased in importance, and ferns declined, perhaps in conditions of warm, moist climate (Ager, 2000). A stable vegetation dominated by 


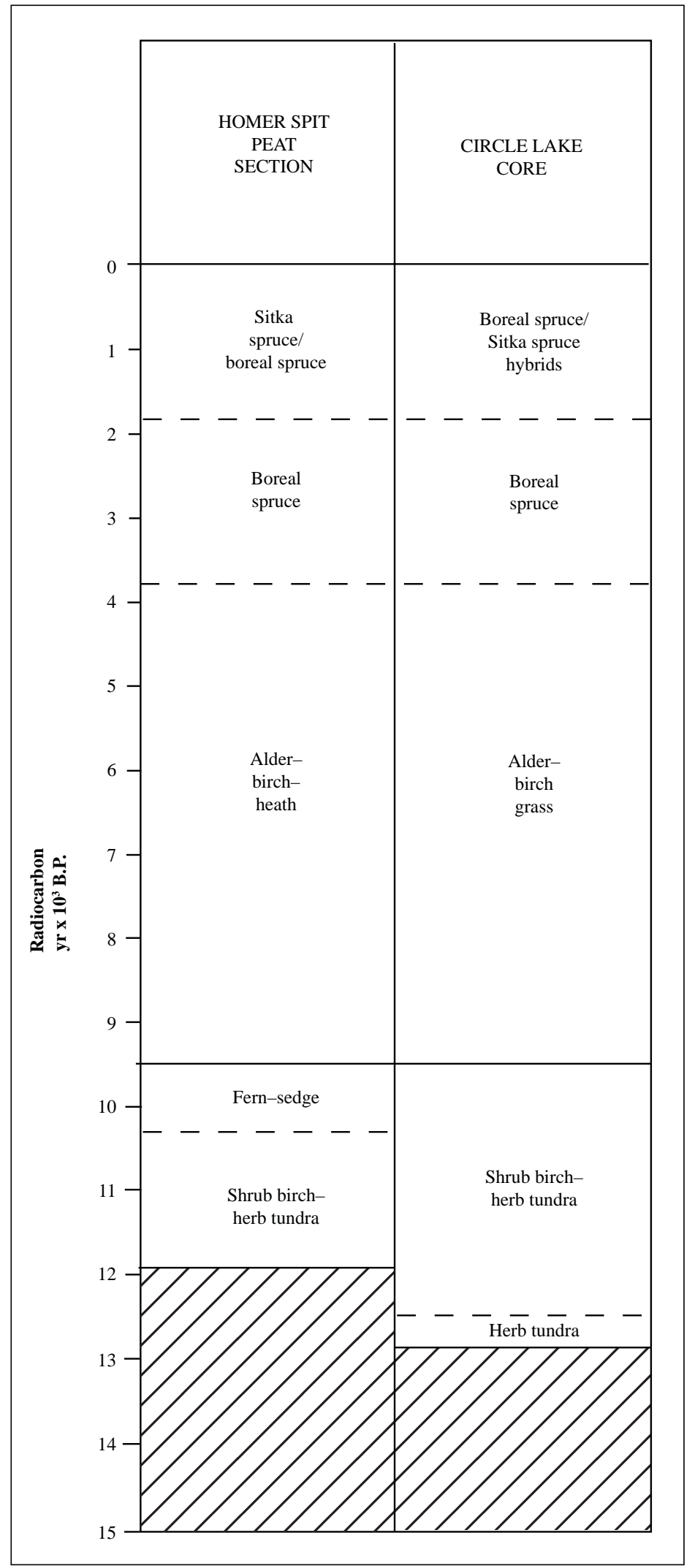

Figure 82. Summary of vegetation histories documented at Homer Spit and Circle Lake sites near Homer (Ager, 2000, fig. 7). alder thickets with subordinate shrub birch apparently then persisted for $\sim 4.5 \mathrm{RC}$ ka (5.1 cal ka). Although boreal spruce pollen, probably from distant sources, started falling on the site well before $3.8 \mathrm{RC}$ ka (4.2 cal ka), significant spruce was present in the area by the time the Hayes tephra was deposited $\sim 3.7 \mathrm{RC} \mathrm{ka}(4.1 \mathrm{cal} \mathrm{ka})$, and spruce has increased in importance since. Sitka spruce, which readily hybridizes with white spruce to form Lutz spruce (Viereck and Little, 1972), apparently moved into the Circle Lake area $1.8 \mathrm{RC}$ kya ( 1.8 cal kya) (fig. 82).

Resource-rich Kachemak Bay is notable for its many (>80) archeological sites, particularly concentrated along the southeastern side, where several bays indent the coast and complex settings have allowed past inhabitants to exploit a wide variety of marine and nearby terrestrial resources. Only a single significant site has been found on the relatively straight northwestern shore, at Cottonwood Creek (SEL-030) near the head of Kachemak Bay (Workman, 1985). Site richness ranges from deep, shell-rich middens with a large inventory of cultural remains, where occupation was long term, to a scatter of broken shells and fire-cracked rocks left after brief visits. The most famous site, the Yukon Island Main Site (SEL-001), was first excavated in 1931 A.D. by Frederica de Laguna (1975), whose work became the foundation for a complex chronology that includes a series of seemingly unrelated prehistoric occupations of variable duration (Workman, 1985; Klein, 1996). Many of the sites in Kachemak Bay are now located in the intertidal zone because this area is tectonically subsiding in the long term, and wave erosion of sites is a serious concern.

Workman (1998a) identified one historic and five prehistoric occupations in Kachemak Bay. The following summary is extracted primarily from his review article. The oldest evidence is attributed to one or possibly two early Holocene sites with core and blade implements made of local and exotic materials and possibly related to inland hunters. Klein and Zollars (2004) obtained ages of $\sim 6.7$ to $~ 7.2$ RC kya ( 7.6 to $\sim 8.0$ cal kya) for a collection 
of two cores and three core flakes from a stratified site in Aurora Lagoon (SEL-009), the oldest culturally related dates in Kachemak Bay. Very brief visits to at least two sites in Kachemak Bay $\sim 4.4$ RC kya ( 4.9 cal kya) left diagnostic large, slender stemmed, ground slate points or knives related to contemporaneous cultures on the Alaska Peninsula. These people were clearly maritime hunters who primarily preyed on small sea mammals, fish, shellfish, and sea birds. Their visits were followed by people of the Arctic Small Tool Tradition from the Naknek area, who visited several sites between $\sim 4.2$ and $\sim 4.0$ RC kya ( 4.6 and 4.2 cal kya) and left small flaked stone bipoints made of exotic lithologies that may have been arrow tips, a few stemmed projectile points, and a distinctive shouldered knife biface.

About a millennium later, people, probably from the Kodiak area, moved into Kachemak Bay to begin the most prolific and widespread occupation, which extended from $~ 3.0$ to $\sim 1.5 \mathrm{RC}$ kya ( 3.2 to $\sim 1.4$ cal kya) (Workman, 1998a). Thousands of recovered artifacts related to this tradition have allowed its subdivision into three phases, Kachemak I-III (Workman, 1998b). Innovations developed during the Kachemak tradition resulted in greater use of ground slate and notched-pebble net weights, more emphasis on art (particularly personal adornment) and craftsmanship, several stylistic changes, and elaborate burial practices. The Kachemak people were clearly adapted to exploiting marine resources and their tradition is known as the Maritime Kachemak Tradition (Workman and McCartney, 1998). Their structures were semisubterranean. Their elaborate ceremonial life is indicated by exquisitely decorated stone oil lamps and the complexity of their burial practices. Temporally and materialistically the Maritime Kachemak Tradition is related to the Riverine Kachemak Tradition of the upper inlet. People of the Maritime Kachemak Tradition abandoned Kachemak Bay $\sim 1.5$ to 1.0 RC kya $(\sim 1.4$ to $\sim 0.9$ cal kya) for unknown reasons. Perhaps they overexploited available resources or could not cope with a colder climate that produced glacial advances in the nearby southern Kenai Mountains, or perhaps they could not compete with the Denaina people, who appeared about this time.

Several small sites dated between $\sim 1.5$ and $\sim 0.2 \mathrm{RC}$ kya ( 1.4 and 0.2 cal kya) in Kachemak Bay feature triangular slate end blades, grooved, stone, splitting and planing adzes, copper tools, and pottery fragmentsobjects that are found in Denaina sites elsewhere. These sites seem to be located where concealment or fortification is important, and warfare between the Denaina Athapaskan speakers and Alutiiq (Pacific) Eskimos to the east may have been a reality of life. The hunters sought both marine and terrestrial prey and persisted until contact was made with Russian explorers in $\sim 1780$
A.D. During the postcontact period, cultural remains in Kachemak Bay include both imported items and items of local manufacture.

\section{END OF ROAD LOG}

This completes the road portion of our field trip. The next stop is accessed by a brief boat ride from the small boat harbor near the end of Homer Spit to the northeastern corner of Halibut Cove, where the bedrock exposures meet the edge of the braid delta from Grewingk Glacier (fig. 1). From there, a well-defined 9.6-km (6-mi) trail loops through the coastal rain forest across the relatively unvegetated braid delta, to the terminal lake (fig. 85), and around through the forest back to the shore of Halibut Cove, where pickups can be arranged. Several water taxis provide transportation to and from the dropoff and pickup points.

\section{STOP 14. TERMINAL ZONE OF GREWINGK GLACIER}

\section{HolOCEne glaciation OF SOUTHERn KenAi MounTAInS}

The climatic record for the past several millennia is probably best interpreted from the responses of glaciers to climatic change. Harding Icefield and the smaller Grewingk-Yalik Ice Complex straddle the crest of the southern Kenai Mountains, and several outlet glaciers extend from these ice-accumulation centers toward Kachemak Bay and the Gulf of Alaska (fig. 83). The Holocene histories of these glaciers have been chronicled, based on the photographic record, lichenometry, tree-ring analyses, and radiocarbon dating. Two episodes of glacial advance are recognized in the southern Kenai Mountains: a First Millennium A.D. expansion that climaxed 600 A.D., and a Little Ice Age advance between 1300 A.D. and 1850 A.D. (Wiles and Calkin, 1990, 1994; Wiles and others, 2007). Studies in the Kenai Fjords demonstrate that tidewater glaciers respond to fjord geometry and sediment supply in addition to glaciological controls and, therefore, are not as sensitive climatic indicators as land-based glaciers (Wiles and others, 1995). Available evidence indicates that land-terminating glaciers on the western flank of the southern Kenai Mountains retreated from their maximum Little Ice Age termini $\sim 75$ yrs prior to glaciers on the eastern flank (Wiles and Calkin, 1994, fig. 21) (fig. 84).

Radiocarbon dating of a tree stump buried by outwash in the forefield of Grewingk Glacier provides evidence for a First Millennium A.D. advance that climaxed 621 A.D. (Wiles and Calkin, 1994). This expansion was less extensive than the Little Ice Age advance and was followed by a terminal recession of 
unknown magnitude. The Little Ice Age advance of Grewingk Glacier climaxed between 1650 A.D. and 1850 A.D. Lichenometric minimum ages establish ice limits in 1858 A.D., 1904 A.D., and 1914 A.D. as Grewingk Glacier began a sustained post-Little Ice Age recession (fig. 85A). Since 1914 A.D., direct observation and photographs indicate that Grewingk Glacier has been steadily retreating, and the terminal lake basin was first exposed between 1926 A.D. and 1951 A.D.

Comparisons of aerial photography, satellite imagery, and airborne instrumental monitoring of modern glaciers in the Kenai Mountains are providing quantitative insights into their current health. Bud Rice (1987) compared the limits of Harding Icefield in 1950 A.D. and 1985 A.D. aerial photographs and determined that there was $\sim 5$ percent reduction during that 35 -yr period. Comparison of aerial photographs taken in 1950 A.D. with 2005 A.D. IKONOS imagery indicates that the greatest mean increase in the area of nunataks $(n=8)$ in the northern Harding Icefield was 45 percent compared to a mean 34 percent increase $(n=6)$ in the GrewingkYalik Ice Complex of the southern Kenai Mountains (Miller and others, 2006). Comparing surface elevations of several glaciers in the Harding Icefield taken from 1950 A.D. topographic maps with more precise laseraltimetry measurements (Echelmeyer and others, 1996) made along flight lines that profiled the same glaciers in the 1990s A.D., Adalgeirsdottir and others (1998) determined that the average ice loss was $\sim 21 \mathrm{~m}(\sim 70 \mathrm{ft})$ during that period (fig. 86). Subsequent laser-altimetry

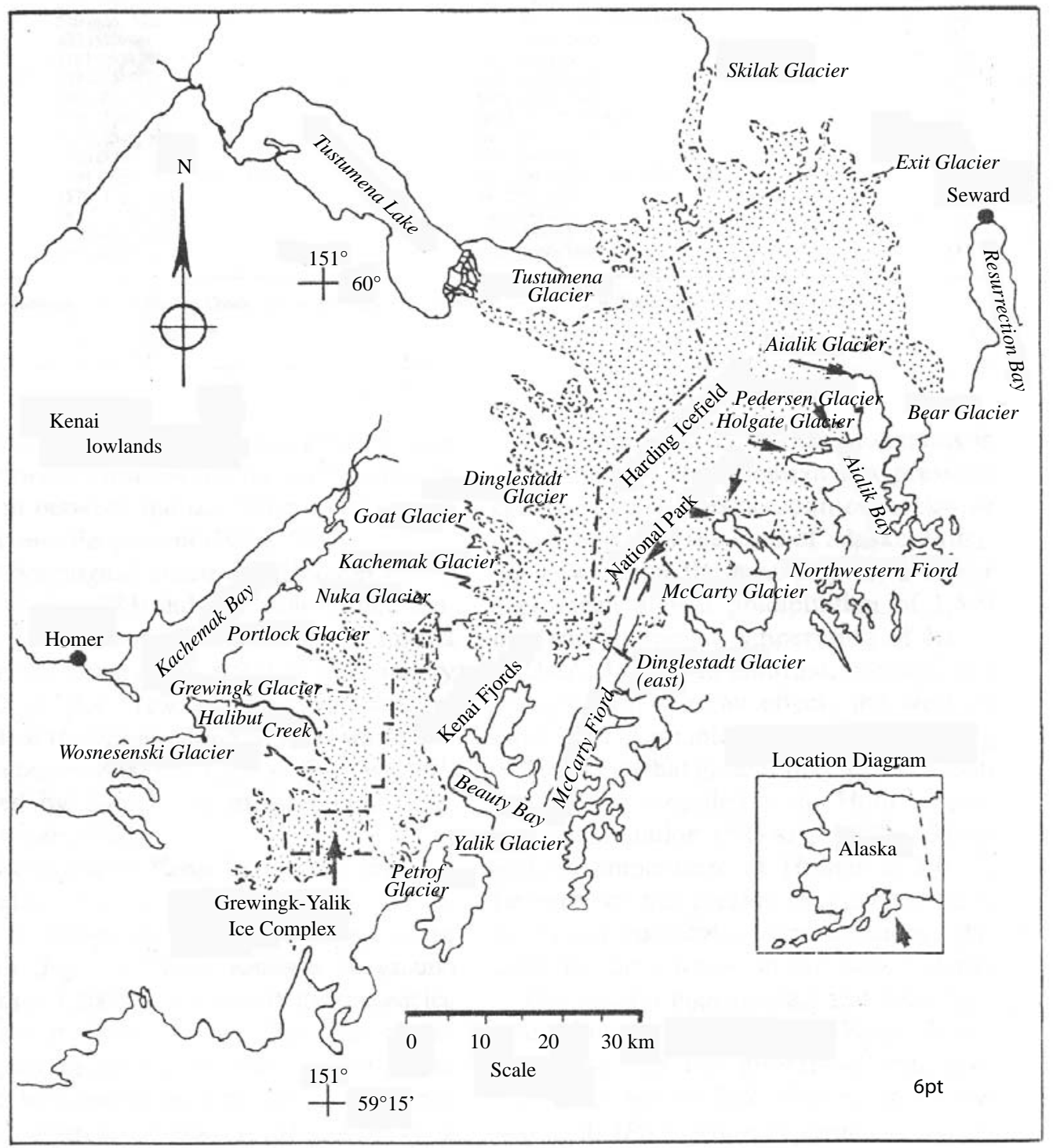

Figure 83. Map of glaciers in southern Kenai Mountains (Wiles and Calkin, 1994, fig. 1). 
surveys of the Harding Icefield confirmed that modern rates of glacier thinning are increasing substantially, up to $2.7 \mathrm{~m} / \mathrm{yr}$ (8.9 ft/yr) (Arendt and others, 2002).

Although the average annual change in thickness of most glaciers associated with Harding Icefield was $\sim 21 \mathrm{~m}$ ( $\sim 0 \mathrm{ft}$ ) from 1950 A.D. into the 1990s A.D., small increases have been measured on Kachemak Glacier and McCarthy Glacier since the 1990s A.D. (Valentine and others, 2004) (fig. 86).

\section{MASsive LANDSLIDE-INDUCED FLOOD}

In October 1967 A.D., a large rockslide from the steep mountain slope above the terminus of Grewingk Glacier crashed onto the glacier terminus and into the terminal lake and initiated a massive flood that inundated the 2-km- (1.2-mi-) wide braid delta of Grewingk Glacier from the lake $6 \mathrm{~km}$ (3.8 mi) to Kachemak Bay (Wiles and Calkin, 1992). The landslide followed a month of record precipitation and involved an estimated $84 \times 10^{6} \mathrm{~m}^{3}$ of fault-shattered bedrock and lateral moraine debris (fig. 85B). The massive impact produced a gigantic flood wave that scoured bedrock and glacial drift up to $\sim 60 \mathrm{~m}$ ( $\sim 200 \mathrm{ft}$ ) above the southern lake shore and crashed against the 1914 A.D. moraine. Some of the flood waters reflected back into the lake basin, depositing a 10-m(33-ft-) high gravel berm between the moraine and the lake shore. However, much of the surge overtopped the 14-m- ( 45-ft-) high Holocene moraines and scoured a 12-m- (39-ft-) deep, 250-m- (820-ft-) wide channel through the moraine belt, which was the major conduit for floodwaters headed for Kachemak Bay (fig. 85B). At a distance of $3.5 \mathrm{~km}$ (2.2 mi) beyond the outer end moraine, measurements of high-water limits indicate that the maximum depth of the surge was still $\sim 6 \mathrm{~m}(\sim 20$ $\mathrm{ft}$ ). Flood-related features on the braid fan include scour channels, uprooted alder clumps, large trees aligned parallel to surge flow with root masses toward the flood source, numerous scattered large boulders, and pits

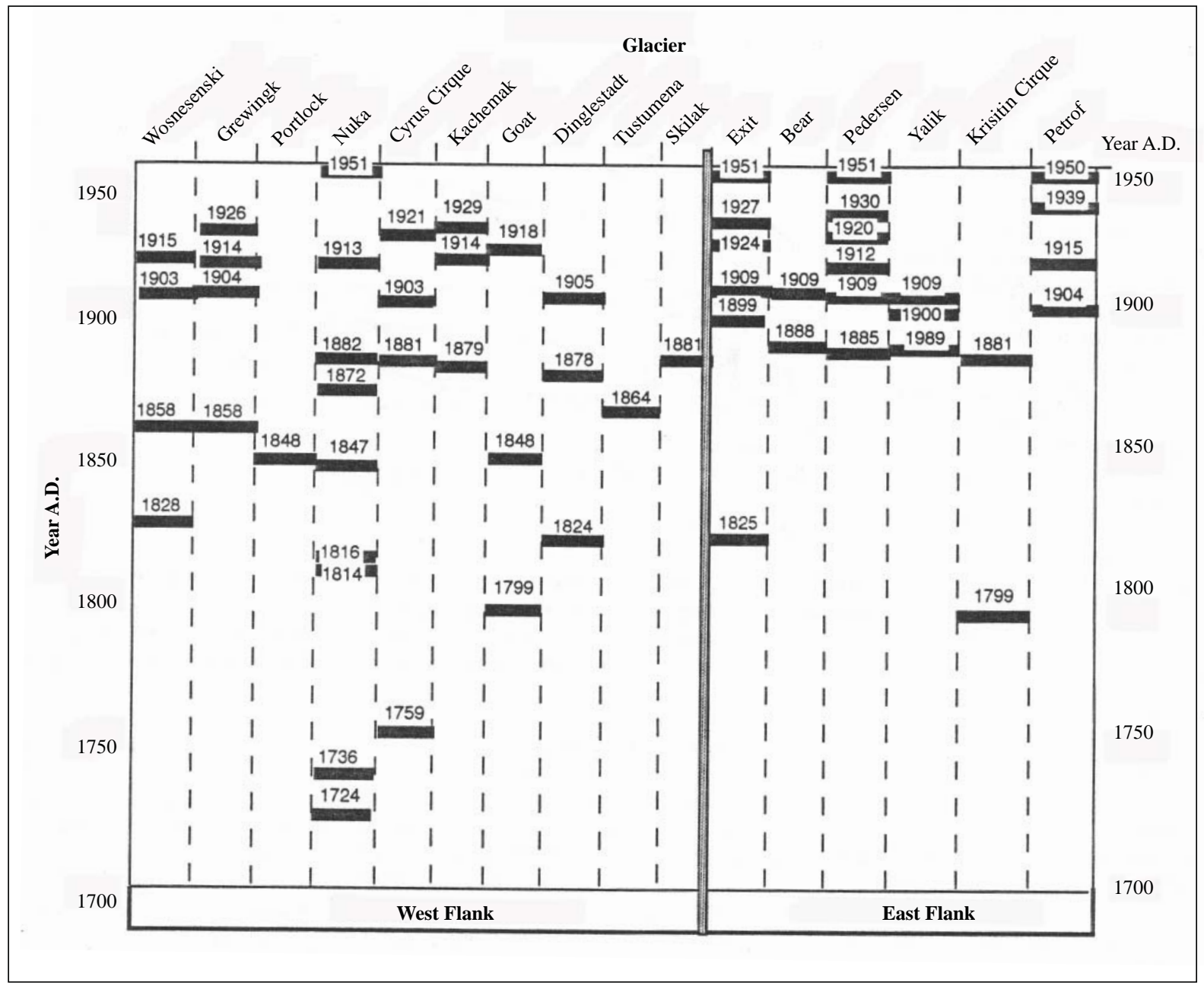

Figure 84. Summary diagram showing minimum dates of moraines of land-terminating glaciers in southern Kenai Mountains (Wiles and Calkin, 1994, fig. 21). 


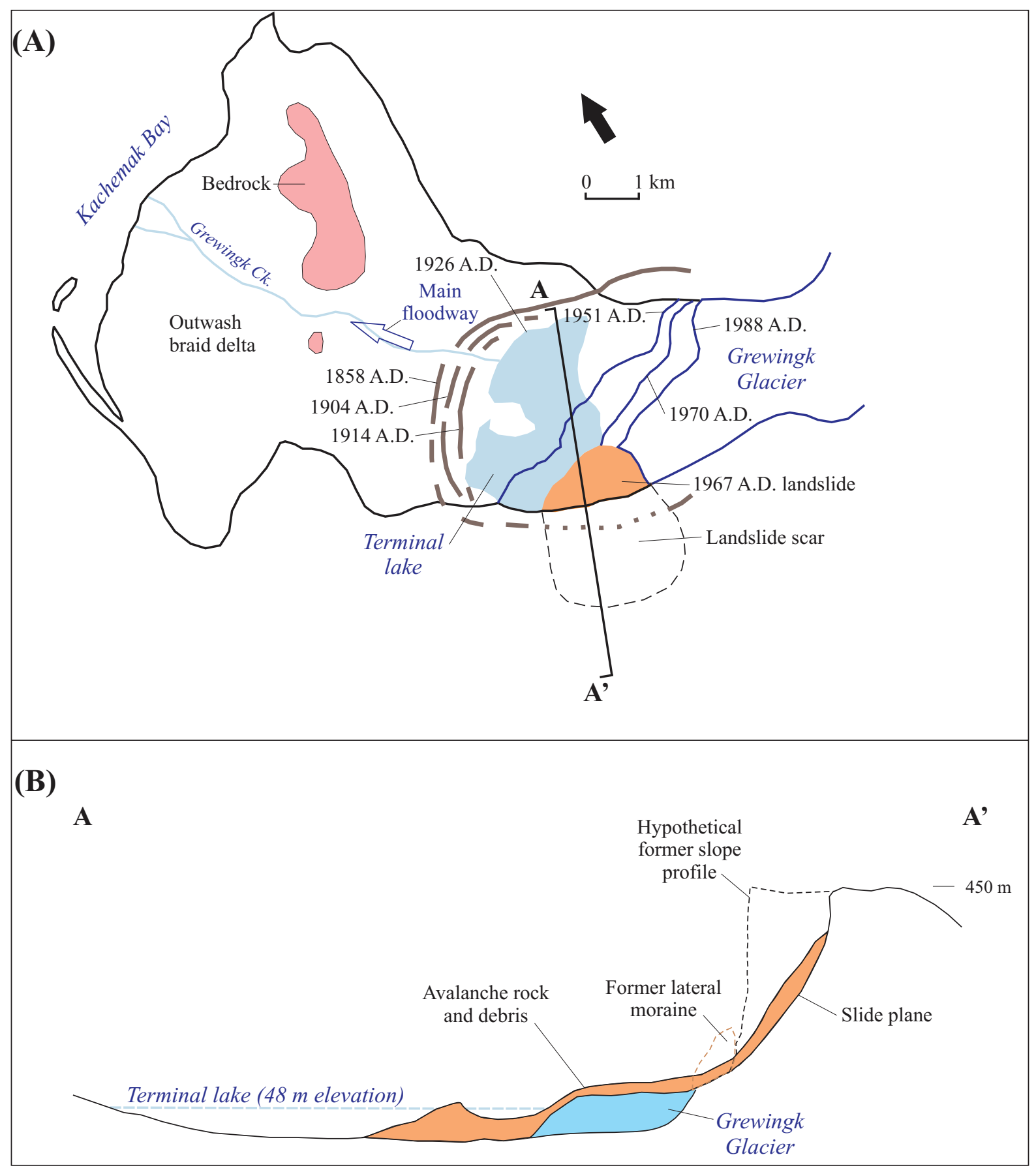

Figure 85. Forefield of Grewingk Glacier, southern Kenai Mountains, showing (A) distribution of Holocene moraines and flood-related features and (B) cross section through landslide source area and body (modified from Wiles and Calkin, 1992, fig. 1 and Wiles and Calkin, 1994, fig. 4). Arrow indicates main path of flood surge. 


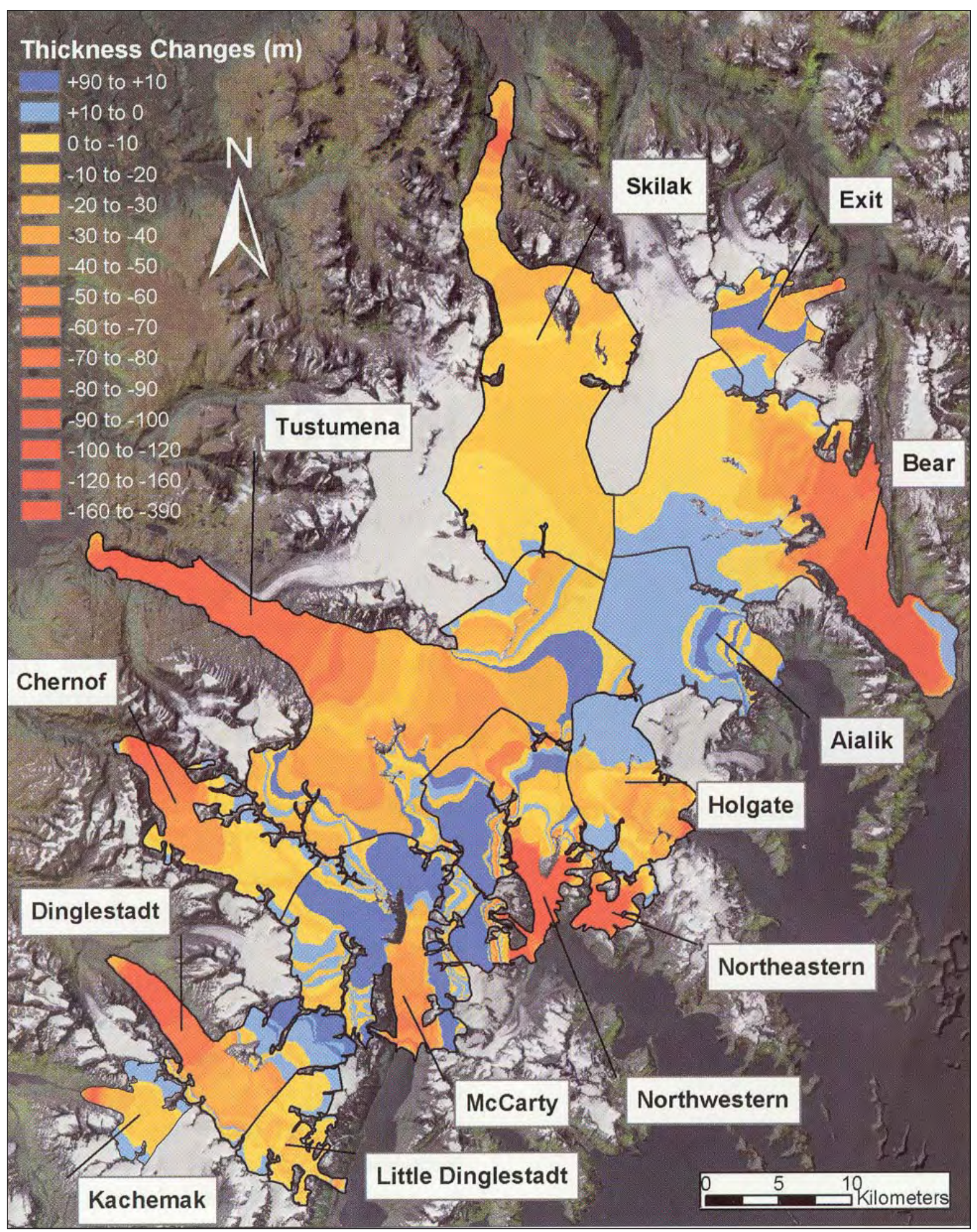

Figure 86. Changes in thickness of Harding Icefield from the 1950s A.D. to the 1990s A.D., based on comparison of elevations on 1950-era topographic maps and airborne laser altimetry profiles (Valentine and others, 2004, fig. 7). 
left by the melting of large ice chunks carried by the flood. Many boulders larger than $35 \mathrm{~cm}$ ( 14 in) are positioned upstream from scour depressions that were probably eroded during the waning flood when less sediment was being transported, indicating that larger boulders were not moved by the flood.

Reconstruction of flood discharge is based on measurements of the area inundated, heights of the surge wave, and maximum size (competence) of boulders transported, if only briefly. On the basis of the apparent competence (35 cm [14 in]), Wiles and Calkin (1992) estimated that the flow moved at least $2.4 \mathrm{~m} / \mathrm{s}(7.8 \mathrm{ft} / \mathrm{s})$. Discharge of the average 3-m- (9.8-ft-) deep flood was estimated to be at least $15,000 \mathrm{~m}^{3} / \mathrm{s}\left(19,600 \mathrm{yd}^{3} / \mathrm{s}\right)$. The total volume of the flood could not be reconstructed because flood duration is not known.

\section{REFERENCES CITED}

Adalgeirsdottir, G., Echelmeyer, K., and Harrison, W., 1998, Elevation and volume changes on the Harding Icefield, Alaska: Journal of Glaciology, v. 42, no. 148, p. 570-582.

Ager, T.A., 1983, Holocene vegetational history of Alaska, in Wright, H.E., Jr., ed., Late-Quaternary environments of the United States, v. 2, The Holocene: Minneapolis, University of Minnesota Press, p. 128-141.

2000, Postglacial vegetation history of the Kachemak Bay area, Cook Inlet, south-central Alaska, in Kelley, K.D., and Gough, L.P., eds., Geologic Studies in Alaska by the U.S. Geological Survey, 1998: U.S. Geological Survey Professional Paper 1815, p. 147-165.

2001, Holocene vegetation history of the northern Kenai Mountains, south-central Alaska, in Gough, L.P., and Wilson, F.H., eds., Geologic Studies in Alaska by the U.S. Geological Survey, 1999: U.S. Geological Survey Professional Paper 1633, p. 91-107.

Ager, T.A., and Brubaker, Linda, 1985, Quaternary palynology and vegetational history of Alaska, in Bryant, V.M., Jr., and Holloway, R.G., eds., Pollen records of late-Quaternary North American sediments: American Association of Stratigraphic Palynologists Foundation, p. 351-384.

Ager, T.A., and Carrara, P.E., 2006, Latest Wisconsin deglaciation and postglacial vegetation development in the Turnagain Arm area, upper Cook Inlet, southcentral Alaska [abs.]: Program and Abstracts of the 28th International Arctic Workshop, Boulder, Colorado, p. 16-18.

Ager, T.A., and Sims, J.D., 1981, Late Quaternary pollen record from Hidden Lake, Kenai Peninsula, Alaska [abs.]: Program and Abstracts, 14th Annual Meeting of American Association of Stratigraphic Palynologists, New Orleans, October 7-10, 1981, p. 8-9. 1984, Postglacial pollen and tephra records from lakes in the Cook Inlet region, southern Alaska, in Coonrad, W.L., and Elliott, R.L., eds., The United States Geological Survey in Alaska: Accomplishments during 1981: U.S. Geological Survey Circular 868, p. 103-105.
Ager, T.A., Rubin, Meyer, and Riehle, J.R., 1985, History of vegetation in the Cook Inlet region, southcentral Alaska, since deglaciation [abs.]: Abstracts of the Proceedings of the Seventeenth Annual Meeting of the American Association of Stratigraphic Palynologists: Palynology, v. 9, p. 1.

Anderson, G.S., 1971, Ground-water exploration, Beaver Creek valley near Kenai, Alaska: U.S. Geological Survey Open-File Report 71-6, 27 p.

Anderson, G.S., 1972, Aquifer test, Soldotna, Alaska: U.S. Geological Survey Water Resources Division (Alaska District) Open-File Report 519, 17 p.

Anderson, G.S., and Jones, S.H., 1972, Water resources of the Kenai-Soldotna area, Alaska: U.S. Geological Survey Water Resources Division (Alaska District) Open-File report 72-7, 81 p., 2 sheets, scale $1: 134,810$.

Anderson, R.S., Hallett, D.J., Berg, E., Jass, R.B., Toney, J.L., de Fontaine, C.S., and DeVolder, A., 2006, Holocene development of boreal forests and fire regimes on the Kenai lowlands of Alaska: The Holocene, v. 16, no. 6, p. 791-803.

Arendt, A.A., Echelmeyer, K.A., Harrison, W.D., Lingle, C.S., and Valentine, V.B., 2002, Rapid wastage of Alaska glaciers and their contribution to rising sea level: Science, v. 297, no. 5580, p. 382-386.

Atwood, B.F., Yamaguchi, D.K., Bondevik, Stein, Barnhardt, W.A., Amidon, L.J., Benson, B.E., Skjerdal, Gudrun, Shulene, J.A., and Nanayama, Futoshi, 2001, Rapid resetting of an estuarine recorder of the 1964 Alaska earthquake: Geological Society of America Bulletin, v. 113, no. 9, p. 1193-1204.

Barnes, F.F., and Cobb, E.H., 1959, Geology and coal resources of the Homer district, Kenai coal field, Alaska: U.S. Geological Survey Bulletin 1058-F, p. F217-F260, 2 sheets, scale 1:63,360.

Barry, M.J., 1997, A history of mining on the Kenai Peninsula, Alaska, Revised Edition: Anchorage, MJP Barry, 296 p.

Bartsch-Winkler, Susan, and Schmoll, H.R., 1987, Earthquake-caused sedimentary couplets in the upper Cook Inlet region, in Hamilton, T.D., and Galloway, J.P., eds., Geologic studies in Alaska by the U.S. 
Geological Survey during 1986: U.S. Geological Survey Circular 998, p. 92-95.

Bartsch-Winkler, Susan, and Schmoll, H.R., 1992, Utility of radiocarbon-dated stratigraphy in determining late Holocene earthquake recurrence intervals, upper Cook Inlet, Alaska: Geological Society of America Bulletin, v. 104, no. 6, p. 684-694.

Begét, J.E., and Kienle, Jürgen, 1992, Cyclic formation of debris avalanches at Mount St. Augustine volcano: Nature, v. 356, p. 701-704.

Begét, J.E., and Nye, C.J., 1994, Postglacial eruption history of Redoubt Volcano: Alaska Journal of Volcanology and Geothermal Research, v. 62, no. 1-4, p. 31-54.

Begét, J.E., Stihler, S.D., and Stone, D.B., 1994, A 500-year-long record of tephra falls from Redoubt Volcano and other volcanoes in upper Cook Inlet, Alaska: Journal of Volcanology and Geothermal Research, v. 62, no. 1-4, p. 55-67.

Berg, E.E., 2001, Refuge Notebook: Like the stock market, the peninsula has its ups and downs: Peninsula Clarion, March 23, 2001, p. C1-C2 [http://kenai.fws. gov/overview/notebook/2001/mar/23mar01.htm].

___ 2003, Refuge Notebook: Black spruce forest spreading onto muskeg peatlands [http://kenai.fws.gov/overview/notebook/2003/ sep/12sep2003.htm].

2004, Refuge Notebook: Ancient bent trees at treeline are straightening up, tell of climate change [http://kenai.fws.gov/overview/notebook/2004/ july/30jul2004.htm].

2005, Refuge Notebook: Shrub invasion shows recent drying of ancient Kenai peatlands [http://kenai.fws.gov/overview/notebook/2005/ sept/16sept2005.htm].

2006, Refuge Notebook: Warmer winters and warmer nights a mixed blessing [http://kenai.fws.gov/overview/notebook/2006/ mar/17mar2006.htm].

2007, Refuge Notebook: Bark beetles will shift Kenai forests toward hardwoods over next century [http://kenai.fws.gov/overview/notebook/2007/ feb/23feb2007.htm].

Berg, E.E., and Anderson, R.S., 2006, Fire history of white and Lutz spruce on the Kenai Peninsula, Alaska, over the last two millennia as determined from soil charcoal: Forest Ecology and Management, v. 227, p. 275-283.

Berg, E.E., Henry, J.D., Fastie, C.L., De Vodler, A.D., and Matsuoka, S.M., 2006, Spruce beetle outbreaks in spruce forests on the western Kenai Peninsula, Alaska, and Kluane National Park and Reserve, Yukon Territory: Relationships with summer temperature and regional differences in disturbance regimes: Forest Ecology and Management, v. 227, p. 219-232.

Birkeland, P.W., 1984, Soils and geomorphology: New York, Oxford University Press, 372 p.

Birkeland, P.W., Machette, M.N., and Haller, K.M., 1991, Soils as a tool for applied Quaternary geology: Utah Geological and Mineralogical Survey Miscellaneous Publication 91-3, 63 p.

Borchardt, G.A., Aruscovage, P.J., and Millard, H.T., Jr., 1972, Correlation of the Bishop ash, a Pleistocene marker bed, using instrumental neutron activation analysis: Journal of Sedimentary Petrology, v. 42, p. 301-306.

Boss, R.F., Lennon, R.B., and Wilson, B.W., 1976, Middle Ground Shoal oil field, Alaska, in Braunstein, J., ed., North American oil and gas fields: American Association of Petroleum Geologists Memoir 24, p. 1-22.

Bradley, D.C., Kusky, T.M., Haeussler, P.J., Karl, S.M., and Donley, D.T., 1999, Geologic map of the Seldovia Quadrangle, south-central Alaska: U.S. Geological Survey Open File Report 99-18, 1 sheet, scale 1:250,000.

Brimberry, D.L., Gardner, P.S., McCullough, M.L., and Trudell, S.E., 1997, Kenai field, the Kenai Peninsula's largest gas field, in Karl, S.M., Vaughn, N.R., and Ryherd, T.J., eds., 1997 guide to the geology of the Kenai Peninsula, Alaska: Anchorage, Alaska Geological Society, p. 28-35.

Brown, J.M., Crossen, K.J., and Holzman, Jacqueline, 1987, A field guide to the geologic hazards of Anchorage and Turnagain Arm, Alaska: Anchorage, Alaska Geological Society guidebook, 62 p.

Brubaker, L.B., Anderson, P.M., and Hu, F.S., 2001, Vegetation ecotone dynamics in southwest Alaska during the late Quaternary: Quaternary Science Reviews, v. 20, p. 175-188.

Buzzell, Rolfe, 1985, History of the upper Kenai River area since the American purchase of Alaska, in Holmes, C.E., ed., Progress report, Sterling Highway archaeological mitigation, phase I excavations at four sites on the Kenai Peninsula: Alaska Division of Geological \& Geophysical Surveys Public Data File 85-4, p. 54-64.

Childers, J.M., 1970, Flood frequency in Alaska: U.S. Geological Survey Open-File Report 70-63, 30 p.

Cieutat, B.A., Goldfarb, R.J, Bradley, D.C., and Roushey, B.H., 1992, Placer gold of the Kenai lowland, in Bradley, W.C., and Dusel-Bacon, Cynthia, eds., Geologic studies in Alaska by the U.S. Geological Survey, 1991: U.S. Geological Survey Bulletin 2041, p. 23-29.

Clarke, A.H., 1981, The freshwater mollusks of Canada: Ottawa, National Museums of Canada, 446 p. 
Clegg, B.F., Turner, Willy, Gavin, D.G., and Hu, F.S., 2005, Morphological differentiation of Betula (birch) pollen in northwest North America and its palaeoecological application: The Holocene, v. 15, no 2, p. 229-237.

Coble, Geoff, and W.J. Nelson and Associates, 1998, Anchor Point Safe Water Corporation water system expansion study: Exploration of alternative water sources: Homer, Coble Geophysical Services and W.J. Nelson \& Associates, Technical Memorandum No. 1, 173 p.

Combellick, R.A., 1984, Surficial-geologic map of the Seward D-6 Quadrangle, Alaska: Alaska Division of Geological \& Geophysical Surveys Report of Investigations 84-15, 1 sheet, scale 1:63,360.

Combellick, R.A., 1991, Paleoseismicity of the Cook Inlet region, Alaska: Evidence from peat stratigraphy in Turnagain and Knik Arms: Alaska Division of Geological \& Geophysical Surveys Professional Report 112, 52 p.

1992, Coseismic and long-term tectonic subsidence in the Cook Inlet region, Alaska: EOS, v. 73, no. 43, p. 361.

1993, The penultimate great earthquake in southcentral Alaska: Evidence from a buried forest near Girdwood, in Solie, D.N., and Tannian, Fran, eds., Short notes on Alaskan geology, 1993: Alaska Division of Geological \& Geophysical Surveys Profession Report 113, p. 7-15.

1994, Investigation of peat stratigraphy in tidal marshes along Cook Inlet, Alaska, to determine the frequency of 1964-style great earthquakes in the Anchorage region: Alaska Division of Geological \& Geophysical Surveys Report of Investigations 94-7, 24 p.

-1997, Evidence of prehistoric great earthquakes in the Cook Inlet region, Alaska, in Karl, S.M., Vaughn, N.R., and Ryherd, T.J., eds., 1997 guide to the geology of the Kenai Peninsula, Alaska: Anchorage, Alaska Geological Society, p. 68-80.

Combellick, R.A., and Pinney, D.S., 1995, Radiocarbon age of probable Hayes tephra, Kenai Peninsula, Alaska, in Combellick, R.A., and Tannian, Fran, eds., Short Notes on Alaska Geology 1995: Alaska Division of Geological \& Geophysical Surveys Professional Report 117, p. 1-9.

Combellick R.A., and Reger, R.D., 1994, Sedimentological and radiocarbon-age data for tidal marshes along eastern and upper Cook Inlet, Alaska: Alaska Division of Geological \& Geophysical Surveys Report of Investigations 94-6, 60 p.

Coulter, H.W., Hopkins, D.M., Karlstrom, T.N.V., Péwé, T.L., Wahrhaftig, Clyde, and Williams, J.R., 1965, Map showing extent of glaciations in Alaska: U.S.
Geological Survey Miscellaneous Geologic Investigations Map I-415, 1 sheet, scale 1:2,500,000.

Crossen, K.J., 1992, Guide to the Little Ice Age landforms and glacial dynamics in Portage Valley and Portage Pass: Anchorage, Alaska Geological Society guidebook, $46 \mathrm{p}$.

Curran, J.H., Meyer, D.F., and Tasker, G.D., 2003, Estimating the magnitude and frequency of peak streamflows for ungaged sites on streams in Alaska and conterminous basins in Canada: U.S. Geological Survey Water-Resources Investigations Report 034188, 101 p., 1 sheet, scale 1:3,771,430.

Daigle, T.A., 2006, Late Holocene climate change at Goat Lake, Kenai Mountains, south-central Alaska: Flagstaff, Northern Arizona University MS thesis, 128 p.

de Fontaine, C.S., Kaufman, D.S., Anderson, R.S., Werner, Al, Waythomas, C.F., and Brown, T.A., 2007, Late Quaternary distal tephra-fall deposits in lacustrine sediments, Kenai Peninsula, Alaska: Quaternary Research, v. 68, no. 1, p. 64-78.

De Laguna, Frederica, 1975, The archaeology of Cook Inlet, Alaska: Anchorage, The Alaska Historical Society, 2nd edition, 264 p., 77 sheets.

De Volder, A.D., 1999, Fire and climate history of lowland black spruce forests, Kenai National Wildlife Refuge, Alaska: Flagstaff, Northern Arizona State MS thesis, $128 \mathrm{p}$.

Dial, R.J., Berg, E.E., Timm, K., McMahon, A., and Geck, J., in press, Changes in the alpine forest-tundra ecotone commensurate with recent warming in southcentral Alaska: Evidence from orthophotos and field plots: Journal of Geophysical Research — Biogeosciences.

Dorava, J.M., and Scott, K.M., 1998, Role of glaciers and glacial deposits in the Kenai River watershed and the implications for aquatic habitat, in Gray, J.E., and Riehle, J.R., eds., Geologic studies in Alaska by the U.S. Geological Survey, 1996: U.S. Geological Survey Professional Paper 1595, p. 3-8.

Echelmeyer, K.A., Harrison, W.D., Larsen, C.F., Sapiano, J.J., Mitchell, J.E., DeMaillie, J., Rabus, B., Adalgeirsdottir, G., and Sombardier, L., 1996, Airborne surface profiling of glaciers: A case study in Alaska: Journal of Glaciology, v. 42, no. 142, p. 538-547.

Eyles, Nicholas, and McCabe, A.M., 1989, The late Devensian ( $<22,000$ B.P.) Irish Sea basin: The sedimentary record of a collapsed ice sheet margin: Quaternary Science Reviews, v. 8, p. 307-351.

Fleisher, P.J., 1986, Dead-ice sinks and moats: Environments of stagnant ice deposition: Geology, v. 14, no. 1, p. 39-42.

Flora of North America Editorial Committee, 1997, Flora of North America north of Mexico, v. 3: Oxford, Oxford University Press. 
Haeussler, P.J., Bruhn, R.L., and Pratt, T.L., 2000, Potential seismic hazards and tectonics of the upper Cook Inlet basin, Alaska, based on analysis of Pliocene and younger deformation: Geological Society of America Bulletin, v. 112, no. 9, p. 1,414-1,429.

Haeussler, P.J., Best, T.C., and Waythomas, C.F., 2002, Paleoseismology at high latitudes: Seismic disturbance of upper Quaternary deposits along the Castle Mountain fault near Houston, Alaska: Geological Society of America Bulletin, v. 114, no. 10, p. 1,296-1,310.

Hamilton, Sarah, and Shennan, Ian, 2005a, Late Holocene great earthquakes and relative sea-level changes at Kenai, southern Alaska: Journal of Quaternary Science, v. 20, no. 2, p. 95111.

Hamilton, Sarah, and Shennan, Ian, 2005b, Late Holocene relative sea-level changes and the earthquake deformation around upper Cook Inlet, Alaska: Quaternary Science Reviews, v. 24, p. 1,479-1,498.

Hamilton, Sarah, Shennan, Ian, Combellick, Rod, Mulholland, John, and Noble, Cate, 2005, Evidence of two great earthquakes at Anchorage, Alaska, and implications for multiple great earthquakes through the Holocene: Quaternary Science Reviews, v. 24, p. 2,050-2,068.

Hamilton, T.D., 1994, Late Cenozoic glaciation of Alaska, in Plafker, George, and Berg, H.C., eds., The Geology of Alaska: Geological Society of America, Geology of North America, v. G-1, p. 813-844.

Hansen, B.C.S., and Engstrom, D.R., 1985, A comparison of numerical and qualitative methods of separating pollen of black and white spruce: Canadian Journal of Botany, v. 63, p. 2,1592,163.

Harden, J.W., 1982, A quantitative index of soil development from field descriptions ${ }^{-}$examples from a chronosequence in central California: Geoderma, v. 28, no. 1, p. 1-28.

Hoekzema, R.R., 1985, Mineral deposits and mining history of the Kenai Peninsula area, in Sisson, Alexander, ed., Guide to the geology of the Kenai Peninsula, Alaska: Anchorage, Alaska Geological Society guidebook, p. 73-87.

Hu, F.S., Brubaker, L.B., and Anderson, P.M., 1993, A 12,000 year record of vegetation change and soil development from Wien Lake, central Alaska: Canadian Journal of Botany, v. 71, p. 1,133-1,142.

___ 1995, Postglacial vegetation and climate change in the northern Bristol Bay region, southwestern Alaska: Quaternary Research, v. 43, no. 3, p. 382-392.

Hu, F.S., Ito, Emi, Brubaker, L.B., and Anderson, P.M., 1998, Ostracode geochemical record of Holocene climatic change and implications for vegetational response in the northwestern Alaska Range: Quaternary Research, v. 49, no. 1, p. 86-95.
Jakob, Matthias, 2005, A size classification for debris flows: Engineering Geology, v. 79, p. 151-161.

Johnson, Kaylene, 2005, Trails across time: History of an Alaska mountain corridor: Cooper Landing, Kenai Mountains-Turnagain Arm Corridor Communities Association, $112 \mathrm{p}$.

Kari, James, 1983, Kalifornsky, the Californian from Cook Inlet, in Antonson, J.M., ed., Alaska in perspective: Alaska Historical Commission, v. 5, no. 1, p. 1-9.

Karl, S.M., Vaughn, N.R., and Ryherd, T.J., 1997a, 1997 guide to the geology of the Kenai Peninsula, Alaska: Anchorage, Alaska Geological Society, 128 p., 3 sheets, various scales.

Karl, Susan, Reger, Richard, Pinney, De Anne, Bradley, Dwight, Swenson, Robert, Combellick, Rod, Kurtak, Joe, Haeussler, Peter, and Brimberry, David, 1997b, Road $\log$ for the 1997 guide to the geology of the Kenai Peninsula, in Karl, S.M., Vaughn, N.R., and Ryherd, T.J., eds., 1997 guide to the geology of the Kenai Peninsula, Alaska: Anchorage, Alaska Geological Society guidebook, p. 83-128.

Karlstrom, T.N.V., 1958, Ground conditions and surficial geology of the Kenai-Kasilof area, Kenai Peninsula, south-central Alaska: U.S. Geological Survey Miscellaneous Geologic Investigations Map I-269, 1 sheet, scale 1:63,360.

1964, Quaternary geology of the Kenai Lowland and glacial history of the Cook Inlet region, Alaska: U.S. Geological Survey Professional Paper 443, 69 p., 6 sheets, various scales.

Kaufman, D.S., Anderson, R.S., Hu, F.S., Berg, Edward, and Werner, Al, in preparation, Strengthened Aleutian Low during the Younger Dryas based on lake-sediment evidence from southern Alaska.

Kaufman, D.S., Ager, T.A., Anderson, N.J., Anderson, P.M., Andrews, J.T., Bartlein, P.J., Brubaker, L.B., Coats, L.L., Cwynar, Les C., Duvall, M.L., Dyke, Arthur S., Edwards, M.E., Eisner, W.R., Gajewski, K., Geirsdottir, A., Hu, F.S., Jennings, A.E., Kaplan, M.R., Kerwin, M.W., Lozhkin, A.V., MacDonald, G.M., Miller, G.H., Mock, C.J., Oswald, W.W., Otto-Bliesner, B.L., Porinchu, D.F., Ruehland, K., Smol, J.P., Steig, E.J., and Wolfe, B.B., 2004, Holocene thermal maximum in the western Arctic $\left(0-180^{\circ} \mathrm{W}\right)$ : Quaternary Science Reviews, v. 23, no. 5-6, p. 529-560.

Kienle, Jürgen, 1990, Augustine, Cook Inlet, Alaska, in Wood, C.A., and Kienle, Jürgen, eds., Volcanoes of North America: Cambridge, Cambridge University Press, p. 79-80.

Klein, Eric, Berg, E.E., and Dial, Roman, 2005, Wetland drying and succession across the Kenai Peninsula lowlands, south-central Alaska: Canadian Journal of Forest Research, v. 35, no. 8, p. 1,931-1,941. 
Klein, J.R., 1996, Archaeology of Kachemak Bay, Alaska: Homer, Kachemak Country Publications, $93 \mathrm{p}$.

Klein, J.R., and Zollars, Peter, 2004, Radiocarbon dates from the early Holocene component of a stratified site (SEL-009) at Aurora Lagoon, Kenai Peninsula, Alaska: Alaska Journal of Anthropology, v. 2, nos. 1-2, p. 118-124.

Kurtak, J.M., Huber, Carol, and Rathbun, Nathan, 1997, Gold placer geology and mining history of the northern Kenai Peninsula and Girdwood area, Alaska, in Karl, S.M., Vaughn, N.R., and Ryherd, T.J., eds., 1997 guide to the geology of the Kenai Peninsula, Alaska: Anchorage, Alaska Geological Society, p. 13-17.

Lemke, Kathleen, 1994, Late glacial retreat in the Kenai Lake trough: Anchorage, University of Alaska Student Showcase Journal, v. 10, p. 35-45.

Lemke, K.J., 2000, Holocene tephrostratigraphy, southern Kenai Peninsula, lower Cook Inlet, Alaska: Logan, Utah State University MS thesis, 96 p.

Lethcoe, Jim, 1990, An observer's guide to the geology of Prince William Sound, Alaska: Valdez, Prince William Sound Books, 224 p.

Magoon, L.B., Adkison, W.L., and Edbert, R.M., 1976, Map showing geology, wildcat wells, Tertiary plant fossil localities, K-Ar age dates, and petroleum operations, Cook Inlet area, Alaska: U.S. Geological Survey Miscellaneous Investigations Map I-1019, 3 sheets, scale 1:250,000.

Mann, D.H., and Crowell, A.L., 1996, A large earthquake occurring 700-800 years ago in Aialik Bay, southern coastal Alaska: Canadian Journal of Earth Sciences, v. 33, no. 1, p. 117-126.

Mann, D.H., and Peteet, D.M., 1994, Extent and timing of the last glacial maximum in southwestern Alaska: Quaternary Research, v. 42, no. 2, p. 136-148.

March, G.D., and Robertson, L.G., 1982, Snow avalanche atlas, Seward Highway, southcentral Alaska: Alaska Division of Geological \& Geophysical Surveys Professional Report 81, 168 p., 3 sheets, scale $1: 63,360$.

Martin, G.C., Johnson, B.L., and Grant, U.S., 1915, Geology and mineral resources of Kenai Peninsula, Alaska: U.S. Geological Survey Bulletin 587, 243 p., 3 map sheets, various scales.

Mason, Owen, Neal, W.J., Pilkey, O.H., Bullock, Jane, Fathauer, Ted, Pilkey, Deborah, and Swanston, Douglas, 1997, Living with the coast of Alaska: Durham, Duke University Press, 348 p.

Mayo, L.R., Zenone, C., and Trabant, D.C., 1977, Reconnaissance hydrology of Portage Glacier basin, Alaska: U.S. Geological Survey, Hydrologic Investigations Atlas HA-0583, 2 sheets.
McCulloch, D.S., 1966, Slide-induced waves, seiching and ground fracturing caused by the earthquake of March 27, 1964, at Kenai Lake, Alaska: U.S. Geological Survey Professional Paper 543-A, 41 p., 1 sheet, scale 1:63,360.

McPherson, J.G., Shanmugam, Ganapathy, and Moiola, R.J., 1987, Fan-deltas and braid deltas: Varieties of coarse-grained deltas: Geological Society of America Bulletin, v. 99, p. 331340.

Miller, Amy, Spencer, Page, Carlson, M.L., and Lipkin, Rob, 2006, Vascular plant inventory \& baseline monitoring of nunatak communities (2005), Lake Clark National Park and Preserve and Kenai Fjords National Park: Anchorage, National Park Service, 44 p.

Miller, R.D., and Dobrovolny, Ernest, 1959, Surficial geology of Anchorage and vicinity, Alaska: U.S. Geological Survey Bulletin 1093, 128 p. 1 sheet, scale 1:63,360.

Muhs, D.R., Ager, T.A., Bettis, E.A., III, McGeehin, John, Been, J.M., Begét, J.E., Pavich, M.J., Stafford, T.W., Jr., and Stevens, D.S.P., 2003, Stratigraphy and paleoclimatic significance of late Quaternary loess-paleosol sequences of the late interglacial-glacial cycle in central Alaska: Quaternary Science Reviews, v. 22, p. 1,947-1,986.

Munter, J.A., and Maurer, M.A., 1991, Preliminary description of ground-water conditions at Sterling, Alaska: Alaska Division of Geological \& Geophysical Surveys Public Data File 91-31, 25 p., 3 sheets, scale 1:11,950.

Nelson, A.R., Shennan, Ian, and Long A.J., 1996, Identifying coseismic subsidence in tidal-wetland stratigraphic sequences at the Cascadia subduction zone of western North America: Journal of Geophysical Research, v. 101, no. B3, p. 6,115-6,135.

Nelson, G.L., 1981, Hydrology and the effects of industrial pumping in the Nikiski area, Alaska: U.S. Geological Survey Water-Resources Open-File Report 81-685, 22 p.

Nelson, G.L., and Johnson, P.R., 1981, Ground-water reconnaissance of part of the lower Kenai Peninsula, Alaska: U.S. Geological Survey Open-File Report 81-684, 22 p.

Nelson, S.W., Dumoulin, J.A., and Miller, M.L., 1985, Geologic map of the Chugach National Forest, Alaska: U.S. Geological Survey Miscellaneous Field Studies Map MF-1645-B, 16 p., 1 sheet, scale 1:250,000.

Newbould, Doug, 2007, Kenai Mountain treeline advances like spreading bread mold, not like rising bathtub water [http://kenai.fws.gov.overview/notebook/2007/june/01june2007.htm].

Ovenshine, A.T., Lawson, D.E., and Bartsch-Winkler, S.R., 1976, The Placer River Silt-intertidal sedimen- 
tation caused by the Alaska earthquake of March 27, 1964: U.S. Geological Survey Journal of Research, v. 4, no. 2, p. 151-162.

Perkins, J.A., and Sims, J.D., 1983, Correlation of Alaskan varve thickness with climatic parameters and use in paleoclimatic reconstruction: Quaternary Research, v. 20, no. 3, p. 308-321.

Peteet, D.M., Sauer, K.L., and Jones, Mariam, 2007, Muskeg archives of vegetation, migration, and climate history in the Gulf of Alaska arc [abs.]: Abstracts with Programs, 103rd Cordilleran Section Meeting of Geological Society of America, 4-6 May, Bellingham, Washington, p. 18.

Pinney, D.S., 1993, Late Quaternary glacial and volcanic stratigraphy near Windy Creek, Katmai National Park, Alaska: Fairbanks, University of Alaska MS thesis, $185 \mathrm{p}$.

Pinney, D.S., and Begét, J.E., 1991, Late Pleistocene volcanic deposits near the Valley of Ten Thousand Smokes, Katmai National Park, Alaska, in Reger, R.D., ed., Short Notes on Alaska Geology 1991: Alaska Division of Geological \& Geophysical Surveys Professional Report 111, p. 45-53.

Plafker, George, 1956, Occurrence of diatomaceous earth near Kenai, Alaska: U.S. Geological Survey Bulletin 1039-B, p. B25-B31, 1 sheet, scale 1:3,530.

1965, Tectonic deformation associated with the 1964 Alaska earthquake: Science, v. 148, no. 3,678, p. 1-13.

1969, Tectonics of the March 27, 1964, Alaska earthquake: U.S. Geological Survey Professional Paper 543-I, 74 p., 2 sheets, scales 1:2,000,000, and 500,000.

Post, Austin, and Mayo, L.R., 1971, Glacier dammed lakes and outburst floods in Alaska: U.S. Geological Survey Hydrologic Investigations Atlas HA-455, 10 p., 2 sheets, scale 1:1,000,000.

Rawlinson, S.E., 1986, Peat-resource and surficialgeologic map of the south Kenai Peninsula, Alaska: Alaska Division of Geological \& Geophysical Surveys Report of Investigations 86-15, 1 sheet, scale 1:31,680.

Reed, B.L., Miesch, A.T., and Lanphere, M.A., 1983, Plutonic rocks of Jurassic age in the Alaska-Aleutian Range batholith: Chemical variation and polarity: Geological Society of America Bulletin, v. 94, no. 10, p. 1,232-1,240.

Reger, D.R., 1985, Previous archaeological research in the region, in Holmes, C.E., ed., Progress report, Sterling Highway archaeological mitigation, phase I excavations at four sites on the Kenai Peninsula: Alaska Division of Geological \& Geophysical Surveys Public Data File 85-4, p. 65-67.
Reger, D.R., 1987, Archeology of a late prehistoric subsistence locality, the Clam Gulch site (49KEN045): Anthropological Papers of the University of Alaska, v. 21, nos. 1-2, p. 89103.

1998, Archaeology of the northern Kenai Peninsula and upper Cook Inlet: Arctic Anthropology, v. 35 , no. 1 , p. 160-171.

2004, Early use of the Kenai River; v. 1, Archaeological background: Report to Kenai Watershed Forum and Kenai River Center (Grant KWF-KRC005, 'Kenai River prehistory'), 48 p.

Reger, R.D., 1979, Bluff Point landslide, a massive ancient rock failure near Homer, Alaska, in Short notes on Alaskan Geology, 1978: Alaska Division of Geological \& Geophysical Surveys Geologic Report 61, p. 5-9.

Reger, R.D., 2004, Drainage history of the lower Kenai River corridor between Skilak Lake and Kenai, Alaska: Report to Kenai Watershed Forum and Kenai River Center (Grant KWF-KRC-002, 'Drainage history'), 74 p., 9 sheets, scale 1:25,000.

Reger, R.D., and Carver, C.L., 1977, Photointerpretive map of the geologic materials of the southern Kenai lowlands, Alaska: Alaska Division of Geological \& Geophysical Surveys Open-File Report 111B, 1 sheet, scale 1:63,360.

Reger, R.D., and Hopkins, D.M., 1995, Stratigraphy and implications of a lakeside section, Glacial Lake, southwestern Kigluaik Mountains, Seward Peninsula, Alaska, in Combellick, R.A., and Tannian, Fran, eds., Short Notes on Alaska geology 1995: Alaska Division of Geological \& Geophysical Surveys Professional Report 117, p. 47-52.

Reger, R.D., and Petrik, W.A., 1993, Surficial geology and late Pleistocene history of the Anchor Point area, Alaska: Alaska Division of Geological \& Geophysical Surveys Public-Data File 93-50b, 8 p., 1 sheet, scale 1:25,000.

Reger, R.D., and Pinney, D.S., 1996, Late Wisconsin glaciation of the Cook Inlet region with emphasis on Kenai Lowland and implications for early peopling, in Davis, N.Y., and Davis, W.E., eds., Adventures through time: Readings in the anthropology of Cook Inlet, Alaska: Anchorage, Cook Inlet Historical Society, p. 15-35.

Reger, R.D., and Pinney, D.S., 1997, Last major glaciation of Kenai Lowland, in Karl, S.M., Vaughn, N.R., and Ryherd, T.J., eds., 1997 guide to the geology of the Kenai Peninsula, Alaska: Anchorage, Alaska Geological Society, p. 54-67.

Reger, R.D., and Updike, R.G., 1983, Upper Cook Inlet region and the Matanuska Valley, in Péwé, T.L., and Reger, R.D., eds., Guidebook to permafrost 
and Quaternary geology along the Richardson and Glenn Highways between Fairbanks and Anchorage, Alaska: Alaska Division of Geological \& Geophysical Surveys Guidebook 1, p. 185-263, 1 sheet, scale 1:250,000.

Reger, R.D., Combellick, R.A., and Brigham-Grette, Julie, 1995, Update of latest Wisconsin events in the upper Cook Inlet region, southcentral Alaska, in Combellick, R.A., and Tannian, Fran, eds., Short Notes on Alaska Geology 1995: Alaska Division of Geological \& Geophysical Surveys Professional Report 111, p. 45-53.

Reger, R.D., Pinney, D.S., Burke, R.M., and Wiltse, M.A., 1996, Catalog and preliminary analyses of geologic data related to middle to late Quaternary deposits, eastern and northern Cook Inlet region, Alaska: Alaska Division of Geological \& Geophysical Surveys Report of Investigations 95-6, 188 p., 5 sheets, scale 1:250,000.

Rice, Bud, 1987, Change in Harding Icefield, Kenai Peninsula, Alaska: Fairbanks, University of Alaska MS thesis, $116 \mathrm{p}$.

Riehle, J.R., 1985, A reconnaissance of the major Holocene tephra deposits in the upper Cook Inlet region, Alaska: Journal of Volcanology and Geothermal Research, v. 26, no. 1-2, p. 37-74.

Riehle, J.R., Bowers, P.M., and Ager, T.A., 1990, The Hayes tephra deposits, an upper Holocene marker horizon in south-central Alaska: Quaternary Research, v. 33, no. 3, p. 276-290.

Riehle, J.R., Kienle, Jürgen, and Emmel, K.S., 1981, Lahars in Crescent River valley, lower Cook Inlet, Alaska: Alaska Division of Geological \& Geophysical Surveys Geologic Report 51, 10 p.

Riehle, J.R., Ager, T.A., Reger, R.D., Pinney, D.S., and Kaufman, D.S., 2006 (in press), Stratigraphic and compositional complexities of the late Quaternary Lethe tephra in south-central Alaska: Quaternary International, 19 p.

Reimer, P.J., Baillie, M.G.L., Bard, E., Bayliss, A., Beck, J.W., Bertrand, C.J.H., Blackwell, P.G., Buck, C.E., Burr, G.S., Cutler, K.B., Damon, P.E., Edwards, R.L., Fairbanks, R.G., Friedrich, M., Guilderson, T.P., Hogg, A.G., Hughen, K.A., Kromer, B., McCormac, G., Manning, S., Ramsey, C.B., Reimer, R.W., Remmele, S., Southon, J.R., Stuiver, M., Talamo, S., Taylor, F.W., van der Plicht, J., and Weyhenmeyer, C.E., 2004, INTCAL04 terrestrial radiocarbon age calibration, 0-26 cal kyr BP: Radiocarbon, v. 46, p. 1,029-1,058.

Rymer, M.J., and Sims, J.D., 1982, Lake-sediment evidence for the date of deglaciation of the Hidden Lake area, Kenai Peninsula, Alaska: Geology, v. 10, no. 6, p. 314-316.
Schmoll, H.R., and Yehle, L.A., 1986, Pleistocene glaciation of the upper Cook Inlet basin, in Hamilton, T.D., Reed, K.M., and Thorson, R.M., eds., Glaciation in Alaska - the geologic record: Anchorage, Alaska Geological Society, p. 193-218.

Schmoll, H.R., Szabo, B.J., Rubin, Meyer, and Dobrovolny, Ernest, 1972, Radiometric dating of marine shells from the Bootlegger Cove Clay, Anchorage, Alaska: Geological Society of America Bulletin, v. 83, no. 4, p. 1,107-1,114.

Schmoll, H.R., Yehle, L.A., Gardner, C.A., and Odum, J.K., 1984, Guide to surficial geology and glacial stratigraphy in the upper Cook Inlet basin: Anchorage, Alaska Geological Society guidebook, 89 p.

Schmoll, H.R., Yehle, L.A., and Updike, R.G., 1999, Summary of Quaternary geology of the Municipality of Anchorage, Alaska: Quaternary International, v. 60, p. 3-36.

Scott, K.M., 1982, Erosion and sedimentation in the Kenai River, Alaska: U.S. Geological Survey Professional Paper 1235, 35 p.

Shennan, Ian, and Hamilton, Sarah, 2006, Coseismic and pre-seismic subsidence associated with great earthquakes in Alaska: Quaternary Science Reviews, v. 25, p. 1-8.

Sisson, Alexander, 1985, Guide to the Geology of Kenai Peninsula, Alaska: Anchorage, Alaska Geological Society guidebook, $138 \mathrm{p}$.

Smith, G.A., 1993, Missoula flood dynamics and magnitudes inferred from sedimentology of slack-water deposits on the Columbia Plateau, Washington: Geological Society of America Bulletin, v. 105, no. 1, p. 77-100.

Soil Survey Staff, 1975, Soil taxonomy, a basic system of soil classification for making and interpreting soil surveys: Washington, D.C., U.S. Department of Agriculture Soil Conservation Service Agriculture Handbook 436, 754 p.

Stanley, K.W., 1966, Beach changes on Homer spit, in Waller, R.M., Effects of the earthquake of March 27, 1964, in the Homer area, Alaska: U.S. Geological Survey Professional Paper 542-D, p. D20-D27, 1 sheet, scale 1:2,400.

Stihler, S.D., Stone, D.B., and Begét, J.E., 1992, "Varve” counting vs tephrochronology and ${ }^{137} \mathrm{Cs}$ and ${ }^{210} \mathrm{~Pb}$ dating: A comparative test at Skilak Lake, Alaska: Geology, v. 20, no. 11, p. 1,019-1,022.

Suleimani, E.N., Combellick, R.A., Marriott, D., Hansen, R.A., Venturato, A.J., and Newman, J.C., 2005, Tsunami hazard maps of the Homer and Seldovia areas, Alaska: Alaska Division of Geological \& Geophysical Surveys Report of Investigations 2005-2, 28 p., 2 sheets, scale 1:12,500. 
U.S. Army Corps of Engineers, 1967, Flood plain information, Kenai River, Kenai-Soldotna, Alaska, $12 \mathrm{p}$.

-1973, Flood plain information, Kenai River, phase I, Kenai Peninsula Borough, Alaska 25 p.

-1975, Flood plain information, Kenai River, phase II, Kenai Peninsula Borough, Alaska, 25 p.

Utermohle, G.E., Jr., and Munson, R.J., 1972, Foundation report, Kenai River crossing at Kenai (Bridge No. 1149), Project No. S-0463(10): Alaska Department of Highways Engineering Geology Section Engineering Geology \& Foundation report, 17 p.

Valentine, Virginia, Echelmeyer, Keith, Campbell, Susan, and Zirnheld, Sandra, 2004, Harding Icefield's clues to climate change: Alaska Park Science, v. 3, no. 1, p. 12-17.

Viereck, L.A., and Little, E.L., Jr., 1972, Alaska trees and shrubs: Washington, D.C., U.S. Forest Service Agriculture Handbook 410, 265 p.

Waitt, R.B., Jr., 1980, About forty last-glacial Lake Missoula jökulhlaups through southern Washington: Journal of Geology, v. 88, no. 6, p. 653-679.

1985, Case for periodic, colossal jökulhlaups from Pleistocene glacial Lake Missoula: Geological Society of America Bulletin, v. 96, no.10, p.1,271-1,286.

Waller, R.M., 1966, Effects of the earthquake of March 27, 1964, in the Homer area, Alaska: U.S. Geological Survey Professional Paper 542-D, 28 p., 1 sheet, scale $1: 2,400$.

Waller, R.M., Feulner, A.J., and Morris, D.A., 1968, Water resources and surficial geology of the Homer area, south-central Alaska: U.S. Geological Survey Hydrologic Investigations Atlas HA-187, 1 sheet, scale 1:63,360.

Walsh, T.J., Combellick, R.A., and Black, G.L., 1995, Liquefaction features from a subduction zone earthquake: Preserved examples from the 1964 Alaska earthquake: Washington Division of Geology and Earth Resources Report of Investigations 32, 80 p.

Waythomas, C.F., 2000, Reevaluation of tsumani formation by debris avalanche at Augustine Volcano, Alaska, in Keating, B.H., Waythomas, C.F., and Dawson, A.G., eds., Landslides and tsunamis: Basel, Switzerland, Birkhaeuser Verlag, Pure and Applied Geophysics, v. 157, no. 6-8, p. 1,145-1,188.

Waythomas, C.F., and Nye, C.J., 2002, Preliminary volcano-hazard assessment for Mount Spurr Volcano, Alaska: U.S. Geological Survey Open-File Report 01-482, 39 p.

Waythomas, C.F., and Miller, T.P., 1999, Preliminary volcano-hazard assessment for Iliamna Volcano, Alaska: U.S. Geological Survey Open-File Report 99-373, 31 p. 1 sheet, scale 1:20,350.
Waythomas, C.F., and Waitt, R.B., 1998, Preliminary volcano-hazard assessment for Augustine Volcano, Alaska: U.S. Geological Survey Open-File Report 98-106, 39 p. 1 sheet, scale 1:12,038.

Wiles, G.C., and Calkin, P.E., 1990, Neoglaciation in the southern Kenai Mountains, Alaska: Annals of Glaciology, v. 14, p. 319-322.

1992, Reconstruction of a debris-slide-initiated flood in the southern Kenai Mountains, Alaska: Geomorphology, v. 5, p. 535-546.

1994, Late Holocene, high-resolution glacial chronologies and climate, Kenai Mountains, Alaska: Geological Society of America Bulletin, v. 106, no. 2, p. 281-303.

Wiles, G.C., Barclay, D.J., Calkin, P.E., and Lowell, T.V., 2007 (in press), Century to millennial-scale temperature variations for the last two thousand years indicated from glacial geologic records of southern Alaska: Global and Planetary Change, $11 \mathrm{p}$.

Wiles, G.C., Calkin, P.E., and Post, Austin, 1995, Glacier fluctuations in the Kenai fjords, Alaska, U.S.A.: An evaluation of controls on iceberg-calving glaciers: Arctic and Alpine Research, v. 27, no. 3, p. 234-245.

Winkler, G.R., 2000, A geologic guide to Wrangell-Saint Elias National Park and Preserve, Alaska, a tectonic collage of northbound terranes: U.S. Geological Survey Professional Paper 1616, 166 p.

Winkler, G.R., Miller, M.L., Hoekzema, R.B., and Dumoulin, J.A., 1984, Guide to the bedrock geology of a traverse of the Chugach Mountains from Anchorage to Cape Resurrection: Anchorage, Alaska Geological Society, $40 \mathrm{p}$.

Workman, W.B., 1985, Archeological sites along Kachemak Bay, in Sisson, Alexander, Guide to the geology of Kenai Peninsula, Alaska: Anchorage, Alaska Geological Society, p. 87-89.

_ 1998a. Archaeology of the southern Kenai Peninsula: Arctic Anthropology, v. 35, no. 1, p. 146-159.

1998b, Kachemak tradition, in Gibbon, Guy, ed., Archaeology of prehistoric Native America, an encyclopedia: New York, Garland Publishing, Inc., p. 405-406.

Workman, W.B., and McCartney, A.P., 1998, Coast to coast: Prehistoric maritime cultures in the North Pacific: Arctic Anthropology, v. 35, no. 1, p. 361-370.

Yount, M.E., 1990, Redoubt, Cook Inlet, Alaska, in Wood, C.A., and Kienle, Jürgen, eds., Volcanoes of North America: Cambridge, Cambridge University Press, p. 81-82. 


\section{APPENDIX A \\ Calibration of radiocarbon ages}

The following summary of our calibrations of published and unpublished radiocarbon ages in the Kenai Peninsula lowland is organized by author and year. Calibrations were accomplished using CALIB 5.0.1.

Reference

Ager and Sims (1981)
Rymer and Sims (1982)
Ager (1983)

Ager (2000)
Sample no.

\section{Reported mean and standard deviation (radiocarbon yr)}

Calibrated median

(cal yr)

\begin{tabular}{|c|c|c|c|}
\hline Ager and Sims (1981) & USGS-316 & $6,040 \pm 240$ & 6,901 \\
\hline Rymer and Sims (1982) & USGS-317 & $10,380 \pm 80$ & 12,268 \\
\hline \multirow[t]{2}{*}{ Ager (1983) } & W-4822 & $2,820 \pm 130$ & 15,136 \\
\hline & W-4827 & $13,730 \pm 110$ & 16,352 \\
\hline \multirow{9}{*}{ Ager (2000) } & W-5339 & $9,310 \pm 200$ & 10,548 \\
\hline & W-5518 & $12,800 \pm 300$ & 15,041 \\
\hline & W-5521 & $11,800 \pm 300$ & 13,681 \\
\hline & W-5574 & $4,190 \pm 200$ & 4,720 \\
\hline & W-5576 & $5,350 \pm 200$ & 6,121 \\
\hline & W-5905 & $9,550 \pm 300$ & 10,883 \\
\hline & WW-2237 & $2,515 \pm 60$ & 2,583 \\
\hline & WW-2238 & $4,525 \pm 65$ & 5,164 \\
\hline & WW-2339 & $8,340 \pm 120$ & 9,321 \\
\hline \multirow[t]{2}{*}{ Ager (unpublished data) } & W-5494 & $7,880 \pm 250$ & $7,880 \pm 250$ \\
\hline & W-5527 & $10,400 \pm 300$ & $8,76412,186$ \\
\hline \multirow[t]{3}{*}{ Combellick and Pinney (1995) } & Beta-45204 & $3,470 \pm 70$ & 3,745 \\
\hline & Beta-45210 & $3,590 \pm 70$ & 3,896 \\
\hline & Beta-50366 & $3,540 \pm 70$ & 3,826 \\
\hline \multirow{5}{*}{ Karlstrom (1964, table 3) } & L-117K & $400 \pm 150$ & 410 \\
\hline & L-237F & $6,800 \pm 550$ & 7,650 \\
\hline & L-237G & $4,500 \pm 450$ & 5,101 \\
\hline & $\mathrm{W}-78$ & $1,385 \pm 200$ & 1,296 \\
\hline & W-318 & $2,370 \pm 100$ & 2,445 \\
\hline \multirow[t]{2}{*}{ Klein and Zollars (2004) } & Beta-152922 & $7,160 \pm 100$ & 7,985 \\
\hline & Beta-158402 & $6,690 \pm 90$ & 7,559 \\
\hline \multicolumn{4}{|l|}{ Pinney (1993) } \\
\hline Pinney and Begét (1991) & Beta-33666 & $12,640 \pm 100$ & 14,865 \\
\hline Rawlinson (1986, core SK34) & GX-10782 & $9,410 \pm 225$ & 10,688 \\
\hline \multirow[t]{14}{*}{ Reger and others (1996) } & Beta-49104 & $8,080 \pm 250$ & 8,982 \\
\hline & Beta-47182 & $6,120 \pm 50$ & 7,008 \\
\hline & GX-4910 & $1,555 \pm 135$ & 1,466 \\
\hline & GX-4911 & $1,160 \pm 120$ & 1,086 \\
\hline & GX-10649 & $9,850 \pm 390$ & 11,380 \\
\hline & GX-16520 & $7,175 \pm 115$ & 8,001 \\
\hline & GX-16527 & $16,090 \pm 160$ & 18,932 \\
\hline & GX-16528 & $16,000 \pm 150$ & 18,869 \\
\hline & GX-16529 & $14,160 \pm 140$ & 16,381 \\
\hline & GX-17133 & $14,200 \pm 100$ & 16,433 \\
\hline & GX-18404 & $8,745 \pm 100$ & 9,778 \\
\hline & GX-18405 & $8,515 \pm 235$ & 9,524 \\
\hline & GX-20129 & $13,718 \pm 160$ & 15,791 \\
\hline & WSU-4304 & $16,480 \pm 170$ & 19,246 \\
\hline Reger (unpublished data) & GX-16526 & $3,670 \pm 61$ & 2,137 \\
\hline Riehle (1985) & Hayes tephra set & $3,650 \pm 150$ & 3,987 \\
\hline Wiles and Calkin (1994) & Beta-33344 & $3,760 \pm 100$ & 4,135 \\
\hline
\end{tabular}




\title{
1. RESOURCES RESOURCES
}

\author{
STATE OF ALASKA
}

Sarah Palin, Governor

Tom Irwin, Commissioner, Department of Natural Resources

Robert F. Swenson, State Geologist and Acting Director 